\title{
SMOLT QUALITY ASSESSMENT OF
} SPRING CHINOOK SALMON

Annual Report

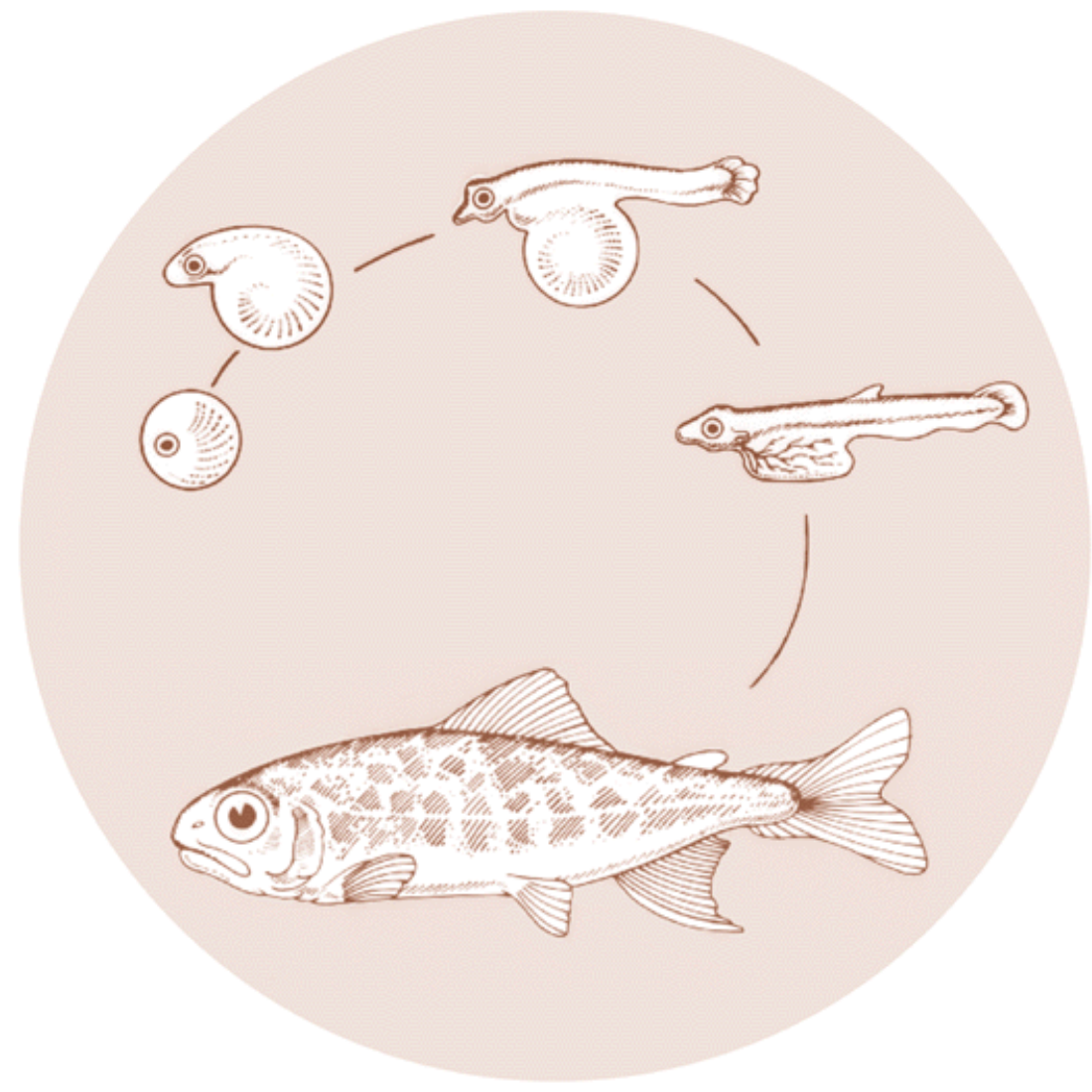

DOE/BP-97300-1 
This report was funded by the Bonneville Power Administration (BPA), U.S. Department of Energy, as part of BPA's program to protect, mitigate, and enhance fish and wildlife affected by the development and operation of hydroelectric facilities on the Columbia River and its tributaries. The views of this report are the author's and do not necessarily represent the views of BPA.

This document should be cited as follows:

Waldo S. Zaugg, Dickhoff, W. W., Beckman, B. R., Mahnken, C. V. W., Winans, G. A., Newcomb, T. W., Coastal Zone and Estuarine Studies Division - National Marine Fisheries Service; Carl B. Schreck, Oregon Cooperative Fishery Research Unit - Oregon State University; Aldo N. Palmisano, Schrock, R. M., Wedemeyer, G. A., U.S. Fish and Wildlife Service; Richard D. Ewing, Oregon Dept. of Fish and Wildlife; C. W. Hopley, Washington Dept. of Fisheries; Smolt Quality Assessment of Spring Chinook Salmon, 1991, Annual Report to Bonneville Power Administration, Portland, OR, Contract DE-AI79-89BP97300, Project 89-046, 115 electronic pages (BPA Report DOE/BP-97300-1)

This report and other BPA Fish and Wildlife Publications are available on the Internet at:

http://www.efw.bpa.gov/cgi-bin/efw/FW/publications.cgi

For other information on electronic documents or other printed media, contact or write to:

Bonneville Power Administration Environment, Fish and Wildlife Division

P.O. Box 3621

905 N.E. 11th Avenue

Portland, OR 97208-3621

Please include title, author, and DOE/BP number in the request. 


\title{
SMOLT QUALITY ASSESSMENT OF SPRING CHNIOOK SALMON
}

\author{
Annual Report \\ Prepared by: \\ Waldo S. Zaugg \\ Walton W. Dickhoff \\ Brian R. Beckman \\ Conrad V. W. Mahnken \\ Gary A. Winans \\ Timothy W. Newcomb \\ Coastal Zone and Estuarine Studies Division \\ National Marine Fisheries Service \\ Carl B. Schreck \\ Oregon Cooperative Fishery Research Unit \\ Oregon State University \\ Aldo N. Palmisano \\ Robin M. Schrock \\ Gary A. Wedemeyer \\ U.S. Fish and Wildlife Service \\ Richard D. Ewing \\ Oregon Department of Fish and Wildlife \\ C. W. Hopley \\ Washington Department of Fisheries
}

Prepared for:

U.S. Department of Energy

Bonneville Power Administration

Environment, Fish and Wildlife

PO Box 3621

Portland, Oregon 97208

Project No. 89-046

Contract No. DE-AI79-89BP97300

April 1991 


\begin{abstract}
The physiological development and physiological condition of spring chinook salmon are being studied at several hatcheries in the Columbia River Basin. The purpose of the study is to determine whether any or several smolt indices can be related to adult recovery and be used to improve hatchery effectiveness. The tests conducted in 1989 on juvenile chinook salmon at Dworshak, Leavenwonh, and Warm Springs National Fish Hatcheries. and the Oregon State Willamette Hatchery assessed saltwater tolerance, gill ATPase, cortisol, insulin, thyroid hormones, secondary stress, fish morphology, metabolic energy stores, immune response, blood cell numbers, and plasma ion concentrations. The study showed that smolt development may have occurred before the fish were released from the Willsmette Hatchery, but not from the Dworshak, Leavenworth or Warm Springs I Hatcheries. These results will be compared to adult recovery data when they become available, to determine which smolt quality indices may be used to predict adult recovery.

The relative rankings of smolt quality at the different hatcheries do not necessarily reflect the competency of the hatchery managers and staff, who have shown a high degree of professionalism and expertise in fish rearing. We believe that the differences in smolt quality are due to the interaction of genetic and environmental factors. One aim of this research is to identify factors that influence smolt development and that may be controlled through fish husbandry to regulate smolt development.
\end{abstract}




\section{CONTENTS}

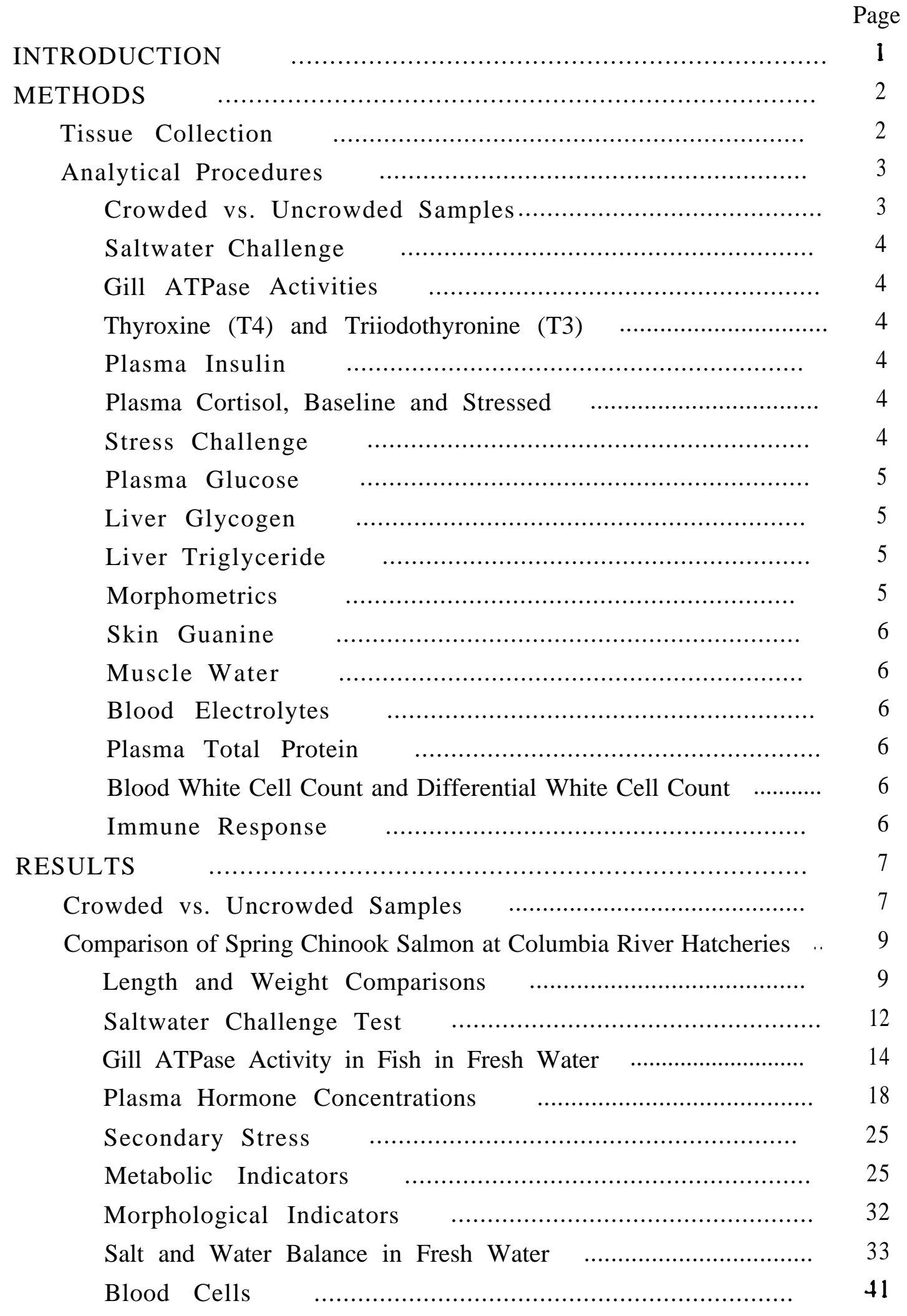




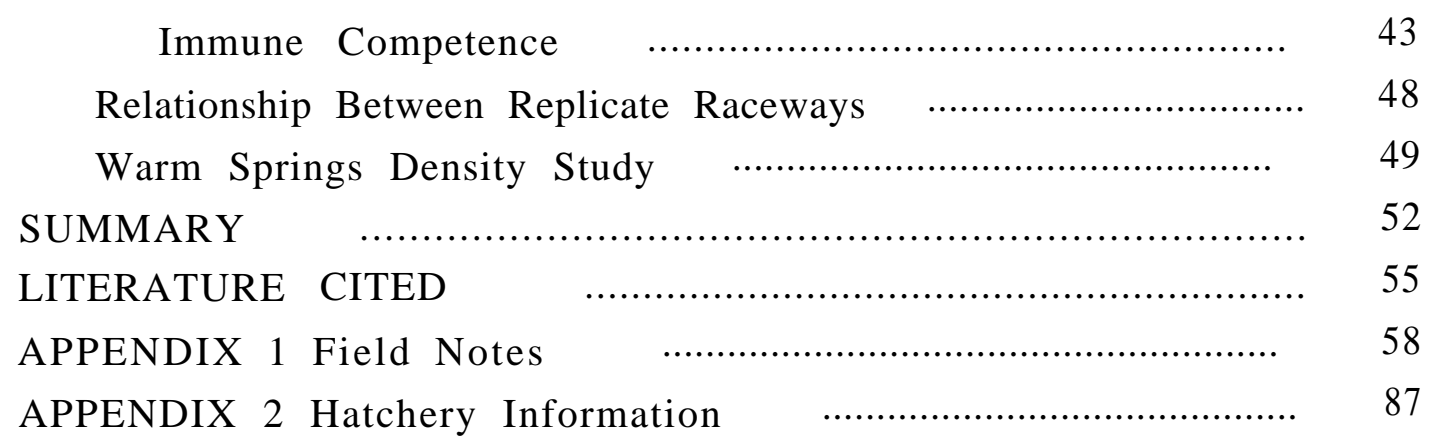




\section{INTRODUCTION}

Intensified efforts in areas of increased production, improvement of dam bypass systems, disease treatment and control, and transportation have not yielded the expected increase in adult returns of hatchery-reared spring chinook salmon (Oncorhynchus tshawytscha) to the upper- and mid-Columbia and Snake River Basins. Apparently other investigations must be included to find solutions to problems of dwindling returns. One useful investigation would be to determine the relation between adult contribution and the quality of fish released from the hatchery - - quality not only as it pertains to disease status or general health, but also as it relates to biological and physiological development. Are the fish released from hatcheries healthy as well as sufficiently developed biologically and physiologically to respond positively to their new stream and ocean environments so that survival will be maximal?

Reports on the relationship between smolt quality of hatchery-released salmonids and their survival to adulthood are scarce, but evidence is accumulating that suggests improvement in quality leads to increased numbers of recovered adults. Soivio and Virtanen (1985) reported correlations between return rates of Atlantic salmon (Salmo salar) and such smolt indices as migration readiness, energy stores, and body silvering, among others. Adult recoveries of fall chinook salmon appeared to be related to their migratory behavior after release as juveniles, and to development of certain aspects of smolt physiology (Zaugg 1989). Giorgi et al. (1988) reported that susceptibility of migrating juveniles to guidance by travelling screens at Columbia River dams may depend in part on the degree of smolt development. Seaward migration rates of juvenile spring chinook salmon doubled when release from the hatchery was delayed by 10 days (Parametrix, Inc. 1983). A more rapid migration translates to less exposure to predators and disease organisms and less competition with resident fish for natural food.

Thus, if there are benefits to releasing quality srnolts, it becomes important to be able to quantitatively define a quality smolt. This study followed physiological development of spring chinook salmon at several hatcheries in the Columbia River Basin. The approach has been to test whether any or several monitored physiological parameters can be used to assess smolt quality, and whether this assessment can be related to adult recovery and used to improve hatchery effectiveness. Smolts were monitored at four hatcheries to assess the effects of variable husbandry techniques, treatments, environments, and gene pools. For example, the effect of rearing density on smolt quality indices was studied at one hatchery. Smolt indices in fish in adjacent raceways were examined at two hatcheries to provide a basis for generalizing from one raceway to the entire hatchery production. Minor 
objectives included evaluation of sampling, and the effect of crowding fish for sampling was examined at one hatchery.

\section{METHODS}

\section{Tissue Collection}

Field sampling of the 1987 brood spring chinook salmon at four hatcheries [Dworshak, Leavenworth, and Warm Springs National Fish Hatcheries (NFH) and Oregon State Willamette Hatchery] began in March 1989 and continued into May 1989. Four raceways (replicates) of production fish were sampled at Dworshak and Leavenworth NFH; two raceways of different densities were sampled at Warm Springs NFH (raceway $11=30,253$ fish, low density; raceway $13=62,788$ fish, normal density); and two release groups (April, raceway 21A and May, raceway 21 B) were monitored at Willamette Hatchery. The same raceways were sampled each time. Three separate 15 -fish samples were taken from each population; these samples were designated Groups I, II, and III (Appendix 1). All fish were measured and weighed to the nearest millimeter $(\mathrm{mm})$ and gram $(\mathrm{g})$. Fish sex was also determined, including an assessment of precocial development in males. The condition factor (body weight/fork length ${ }^{3}$ ) was determined from length and weight data.

The 15 fish in Group I were obtained from the pond by dip net, and then stressed for 1 hour in a perforated bucket suspended in the raceway. Following the stress period, these fish were immersed in a lethal concentration $(200 \mathrm{mg} / \mathrm{L})$ of tricainemethanesulphonate (MS-222). After measuring and weighing, tails were severed at the caudal peduncle and blood was collected in heparinized Pasteur pipets. Plasma obtained from centrifuged samples was used to determine cortisol and glucose (see Appendix 1 for details).

The 15 fish of Group II were obtained from the pond by dip net, usually in two separate takes, and placed immediately in a lethal concentration of MS-22 Fish were measured and weighed, tails were severed at the caudaI peduncle and blood collected in heparinized tubes (microhemstocrit) or Pasteur pipets. Plasma obtained from centrifuged samples was used to determine cortisol, glucose, blood electrolytes, and plasma total protein. Anterior kidneys from these fish plus those from an additional five fish were taken for the immune competence assay. Blood from this group of fish was also used for microhematocrit determinations and for smears.

The 15 fish of Group III were secured with the dip net and held alive in a bucket. One fish at a time was removed, killed by a blow to the head, measured, weighed, and photographed for morphometric analysis. Blood was taken and plasma obtained as 
indicated above. Plasma was used for thyroxine (T4), triiodothyronine (T3), and insulin determinations. A ventral incision was then made, sex noted, and a section ( 0.1 to $0.2 \mathrm{~g}$ ) of the lower lobe of the liver removed, weighed to the nearest $10 \mathrm{mg}$, and frozen immediately with liquid nitrogen; the liver tissue was used later for measuring glycogen content. A second piece of liver was excised and placed in a tube on dry ice for later liver triglyceride analysis. A section of skin $(1 \times 5 \mathrm{~cm})$ in the area between the lateral line and the dorsal fin was removed, frozen on dry ice, and used later for measuring skin guanine content. After removal of the skin, a section ( 0.1 to $0.2 \mathrm{~g}$ ) of white muscle was removed, weighed to the nearest $10 \mathrm{mg}$, placed on dry ice, and used later for measuring tissue water content. Filaments were trimmed from the lower half of two to four gill arches and placed in a tube with $1 \mathrm{ml}$ of a sucrose-ethylenediaminetetraacetic acid-imidazole (SEI) solution. The tube was capped, placed on dry ice, and used later for measuring adenosine triphosphatase (ATPase) activity. Fish were inspected for gross kidney lesions and liver condition.

\section{Analytical Procedures}

\section{Crowded vs. Uncrowded Samples}

After sampling two raceways at the Leavenworth NFH in the normal manner by dip net, the water level was lowered approximately $50 \%$. Fish were crowded by block seine into the downstream $4 \mathrm{~m}$ of the raceway and three random dips (about 150 fish per dip) were taken and placed in a one-quarter sampling net contained in a tub. One fourth of these fish were placed in a plastic barrel containing $80 \mathrm{~L}$ of water. Fifteen fish (as in Group II above) were immediately dipped randomly from the barrel and placed in a lethal concentration of MS-222, and processed for plasma collection (for later cortisol analysis), hematocrits, and blood smears. An additional 15 fish (as in Group III above) were randomly netted, photographed (for morphometric analysis), processed for plasma, liver, skin and muscle collection (for later analysis of T4, T3, insulin, liver glycogen, liver triglyceride, skin guanine, and gill ATPase activity). A stress challenge (as in Group I above) was not performed. Fish remaining in the plastic barrel (about 60) were anesthetized and measured to obtain length frequency data. For additional details, see Appendix 1. 
Saltwater Challenge

Groups of 20 fish each were placed for 24 hours in salt water of 30 parts per thousand $(\%)$ Instant Ocean ${ }^{1}$ artificial sea salts. After the challenge period, fish were removed, weighed, and measured. Blood for plasma sodium and potassium (Clarke and Blackburn 1977) and gill filaments for ATPase analyses were taken as described in Appendix 1.

Gill ATPase Activities

Gill filaments were trimmed from arches and preserved in SEI at $-80^{\circ} \mathrm{C}$ until analyzed for $\mathrm{Na}^{+}-\mathrm{K}^{+}$ATPase activity as described in Appendix 1 and Zaugg (1982). Units of activity are $\mu$ moles $\mathrm{P}_{\mathrm{i}} / \mathrm{mg}$ protein-hour.

Thyroxine (T4) and Triiodothyronine (T3)

Blood plasma concentrations of thyroid hormones were analyzed by radioimmunoassay (RIA) according to methods described by Dickhoff et al. (1978, 1982b).

Plasma Insulin

Blood plasma concentrations of insulin were analyzed by a homologous RIA according to the method described by Plisetskaya et al. (1986).

Plasma Cortisol, Baseline and Stressed

Blood plasma concentrations of cortisol from stressed and unstressed fish were measured by RIA according to the method of Redding et al. (1984).

Stress Challenge

This stress challenge test was described by Barton et al. (1985). Fish were netted and subjected to an acute handling stress in the raceways by suspending them for 1 hour in a perforated bucket such that the backs of the median-sized fish were just under the surface

1 The USC of trade names does not imply cndorscment by the National hlarinc Fishcrics Scrvicc. NOAA. 
of the water. The fish were then anesthetized, and a blood plasma sample was taken for later analysis for conisol and glucose content.

Plasma Glucose

Blood glucose concentrations were determined by a calorimetric procedure (Sigma Chemical Co., St. Louis MO).

Liver Glycogen

Liver glycogen was measured according to the method of Wedemeyer and Yasutake (1977). Glycogen is extracted into potassium hydroxide, precipitated, hydrolyzed to glucose, and quantified with a glucose hexokinase enzymatic determination, measured by spectrophotometry at $340 \mathrm{~nm}$.

Liver Triglyceride

Liver triglyceride concentration was determined according to the following method. Liver samples were homogenized in water and centrifuged. Triglyceride concentrations were measured by the enzymatic method of Bucolo and David (1973). Glycerol is stripped by phospholipase $\mathrm{C}$ and then reduced with glycerol dehydrogenase. The reduced nicotine adenine dinucleotide (NADH) generated is oxidized by para-iodo-nitro-tetratzolium violet, mixed with enzymes and measured by spectrophotometry at $500 \mathrm{~nm}$.

\section{Morphometrics}

Morphometric distances for 26 truss-network characters were calculated from each photograph and analyzed by principal component (PC) analysis (Winans 1984, Winans and Nishioka 1987). 


\section{Skin Guanine}

Skin guanine content as a quantitative measure of silver coloration was determined according to the method of Staley (1984). Skin samples were extracted with $1 \mathrm{~N} \mathrm{HCI}$ for 48 hours at $21^{\circ} \mathrm{C}$. Extracts were adjusted to $\mathrm{pH} 8.1$ and treated with xanthine oxidase and guanase for 2 hours at $21^{\circ} \mathrm{C}$. Guanine concentration was measured by spectrophotometry at $290 \mathrm{~nm}$.

Muscle Water

Water content of dorsal muscle was determined according to the method of Wedemeyer and McLeay ( 198 1).

Blood Electrolytes

Blood plasma $\mathrm{Na}+$ and $\mathrm{K}+$ concentrations were determined by flame photometry; blood plasma $\mathrm{Cl}$ - concentrations were determined using a chloridometer.

\section{Plasma Total Protein}

Plasma total protein was determined using a refractometer calibrated to distilled water.

Blood White Cell Count and Differential White Cell Count

White cell counts were performed to determine the number of white cells per hundred red cells, and to differentiate the number of lymphocytes, neutrophils, and monocytes in 100 white cells according to the method of Wedemeyer and Yasutake (1977).

Immune Response

The immune response of fish was determined by assessing the production of anterior kidney antibody-secreting cells [plaque-forming cells (PFC)] after in vitro exposure to a synthetic antigen (n-initrophenol-lipopolysaccharide) Vibrio anguillarum according to the method of Tripp et al. (1987). 


\section{RESULTS}

\section{Crowded vs Uncrowded Samples}

To resolve the question whether dip-netting fish from an uncrowded raceway obtained appropriate samples for this study, fish collected in two separate raceways under both crowded and uncrowded conditions were compared. This was done at Leavenwonh NFH during 12-14 April 1989. The means and standard deviations of all measurements are shown in Table 1. Since in the routine sampling there was not sufficient blood available from individual fish for all measurements indicated in Table 1, samples from two groups of 15 fish each were processed separately for gill ATPase, hematocrits, thyroid hormones (T4 and T3), and conisol. The data on fork length, body weight, and condition factor were pooled.

No significant differences [analysis of variance (ANOVA), Fisher exact test of protected least significant difference (PLSD); P < 0.05 (Zar 1974)] were obsemed b etween the two groups comparing data on fork length, body weight, condition factor, hematocrit, gill ATPase activity, plasma T3, plasma protein , morphometrics, liver glycogen, muscle water, liver triglyceride, skin guanine, plasma $\mathrm{Na}^{+}$, plasma $\mathrm{Cl}-$, plasma $\mathrm{K}^{+}$, white cell count, lymphocytes, and neutrophils. The values for plasma $\mathrm{T} \downarrow$ and cortisol concentration of the crowded fish in both raceways were significantly higher than those of the uncrowded fish in corresponding raceways. These differences in T4 and conisol may be due to differences in the time of day when the fish were sampled, since both of these hormones may show diurnal variation in their plasma levels (Eales et al. 198 1, Laidley and Leatherland 1988). The uncrowded fish were sampled in the late morning (raceway 32) and late afternoon (raceway 45); the crowded fish were sampled from early (raceway 42) to mid-morning (raceway 45). Furthermore, it might be predicted that cortisol levels would be higher in the crowded fish compared to uncrowded fish since the additional disturbance during crowding may cause stress-related increases in cortisol secretion.

In summary, the sampling of crowded fish gives results equivalent to sampling uncrowded fish for all of the measurements in this experiment. When variation is observed, it may be predicted due to the timing (morning vs afternoon) or stressful nature of the sampling. We concluded that dip netting of uncrowded fish is an appropriate method for obtaining a sample of the fish in the raceway, and no significant advantage is afforded by sampling crowded fish. 
Table 1.-- Comparison of means and standard deviations (in parentheses) among all measurements from fish sampled under crowded and uncrowded conditions at Leavenworth National Fish Hatchery. After sampling two raceways in the normal fashion (by random dip net), fish were crowded into the tail end of the raceway and sampled again using a onequarter sampler. Asterisks indicate statistically significant differences $(\mathrm{P}<0.05$; ANOVA) between values for crowded and uncrowded fish within a raceway .

\begin{tabular}{|c|c|c|c|c|c|}
\hline \multirow[b]{2}{*}{ Measurement } & \multirow[b]{2}{*}{$\mathrm{n}$} & \multicolumn{2}{|c|}{ Crowded } & \multicolumn{2}{|c|}{ Uncrowded } \\
\hline & & Raceway 42 & Raceway 45 & Raceway 42 & Raceway 45 \\
\hline Fork length (mm) & 30 & $124(16)$ & $124(12)$ & $133(15)$ & $127(13)$ \\
\hline Weight $(\mathrm{g})$ & 30 & $22.9(10.9)$ & $23.0(8.6)$ & $27.4(10.0)$ & $23.8(7.5)$ \\
\hline Condition factor & 30 & $1.141(0.06)$ & $1.183(0.052)$ & $1.124(0.056)$ & $1.137(0.051)$ \\
\hline Hematocrit $(\%)$ & 15 & $36(5)$ & $37(3)$ & $34(7)$ & $37(4)$ \\
\hline Gill $\mathrm{Na}^{+}-\mathrm{K}^{+}$ATPase & 15 & $10.0(2.0)$ & $10.9(2.5)$ & $10.1(2.8)$ & $11.3(2.3)$ \\
\hline Plasma T4 (ng/ml) & 15 & $12.6(2.6)^{*}$ & $15.2(4.4)^{*}$ & $5.5(1.1)$ & $9.2(4.2)$ \\
\hline Plasma T3 (ng/ml) & 15 & $6.3(1.5)$ & $6.4(1.5)$ & & $6.8(2.3)$ \\
\hline Plasma conisol (ng/ml) & 15 & $14.7(3.5)^{*}$ & $8.6(3.2)^{*}$ & $9.3(7.1)$ & $3.0(1.8)$ \\
\hline Plasma protein $(\mathrm{g} / \mathrm{dL})$ & 15 & $4.4(0.8)$ & $5.1(1.2)$ & $4.1(0.8)$ & $4.6(0.8)$ \\
\hline Morphometrics (PC) & 15 & $0.136(0.979)$ & $0.464(0.750)$ & $0.0189(0.641)$ & $-0.078(1.091)$ \\
\hline Liver Glycogen $(\mathbf{g} \cdot \mathscr{F})$ & 15 & $1.77(0.20)$ & $1.51(0.09)$ & $1.64(0.19)$ & $1.38(0.16)$ \\
\hline Muscle water (\%) & 15 & $21.6(1.5)$ & $20.3(0.8)$ & $21.3(1.1)$ & $20.7(0.8)$ \\
\hline Liver triglyceride $(\mathrm{mg} / \mathrm{g})$ & 15 & $9.69(1.73)$ & $7.02(2.12)$ & $9.01(2.42)$ & $8.57(1.39)$ \\
\hline Skin guanine $(\mathbf{m g} / \mathbf{g})$ & 15 & $23.82(4.80)$ & $27.29(4.40)$ & $22.83(5.32)$ & $25.09(4.63)$ \\
\hline Plasma $\mathrm{Na}^{+}(\mathrm{mM})$ & 15 & $150.6(3.1)$ & $151.2(2.7)$ & $153.3(1.9)$ & $151.0(2.3)$ \\
\hline Plasma $\mathrm{Cl}^{-}$(mM) & 15 & $128.9(9.2)$ & $126.4(3.5)$ & $133.7(2.7)$ & $119.7(3.9)$ \\
\hline $\operatorname{Plasma~K}^{+}(\mathrm{mM})$ & 15 & $4.83(1.5)$ & $5.49(1.5)$ & $4.36(1.8)$ & $5.64(1.0)$ \\
\hline White cell count $(\mathrm{WCC})(\%)$ & 15 & $0.5(0.3)$ & $0.8(0.3)$ & $0.7(0.3)$ & $0.6(0.3)$ \\
\hline Lymphocytes (\% WCC) & 15 & $94(3)$ & $96(3)$ & $94(3)$ & $93(3)$ \\
\hline Neutrophils (\% WCC) & 15 & $6(3)$ & $4(3)$ & $6(3)$ & $7(3)$ \\
\hline
\end{tabular}




\section{Comparison of Spring Chinook Salmon at Columbia River Hatcheries}

Length and Weight Comparisons

The fork lengths were determined for sampled fish (see Appendix 1). For concise description of the relationships, representative data from sampling Group III at the four hatcheries are shown in Figure 1. The mean fork lengths of the fish sampled at Leavenworth (raceways 42-49), Dworshak (raceway 1 1), and Warm Springs (raceway 11) Hatcheries were most often in the range of 120 to $140 \mathrm{~mm}$ throughout the sampling period. In contrast, mean fork lengths of fish sampled at the Willamette Hatchery (raceway $21 \mathrm{~B}$ ) were in the range of 150 to $170 \mathrm{~mm}$. This trend of larger fish at the Willamette Hatchery was apparent in all sampled groups (Appendix 1).

Average body weights of the fish from sample Group III are shown in Figure 2. Mean body weights of the groups at Leavenworth, Dworshak, and Warm Springs Hatcheries were in the range of 20 to $35 \mathrm{~g}$ throughout the sampling period. Mean body weights of fish at Willamette Hatchery ranged from 40 to $60 \mathrm{~g}$. In comparison with the other hatcheries, greater body weight was evident for all Willamette fish (Appendix 1).

Both the fork length and body weight data indicate that the fish at the Willamette Hatchery were larger than fish at the other three hatcheries. Some of the fish at the Willamette Hatchery were released at a later date (May) than those at the other hatcheries (April). However, the greater size of the Willamette fish was observed in March, and this relationship was maintained throughout the sampling period (Figs. 1 - 2).

The condition factors of sampled fish were calculated from length and weight data (Appendix 1), and are shown in Figure 3. The data shown in Figure 3 were derived from the data shown in Figures 1 and 2. The mean condition factor increased in all fish either during March or from March to April. A marked decrease in condition factor was observed for the Willamette fish sampled between the end of April and the beginning of May.

In summary, the data on fork length, body weight, and condition factor indicate that the fish at Willamette Hatchery were larger than those at the other three hatcheries throughout the period of sampling. The greater decline in condition factor at the time of release of the May group at Willamette Hatchery suggests that these fish may have been the most developed of all fish sampled at the time of release from the hatcheries. A decrease in condition factor is the expected observation for fish undergoing smoltification (Folmar and Dickhoff 1980; Hoar 1988). 


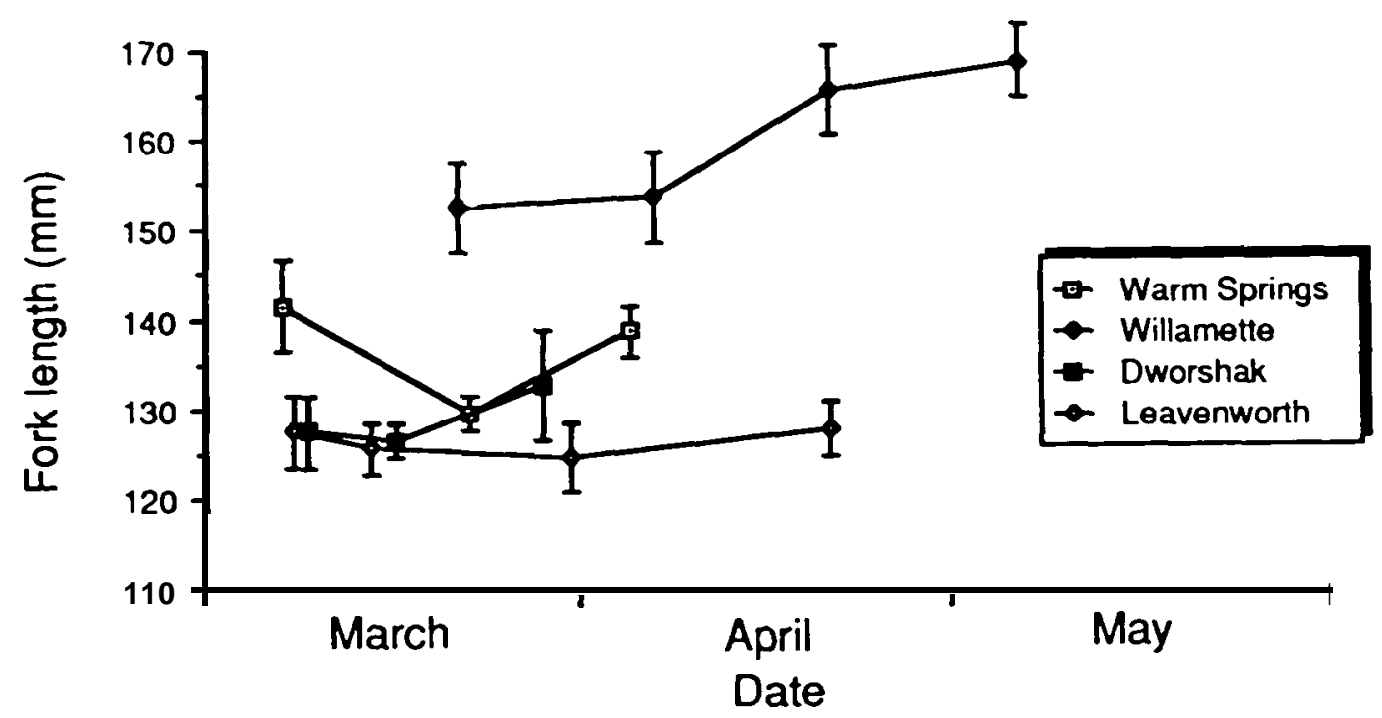

Figure 1.--Mean fork lengths of fish sampled (Group III) at the four hatcheries indicated. Brackets indicate \pm one standard error.

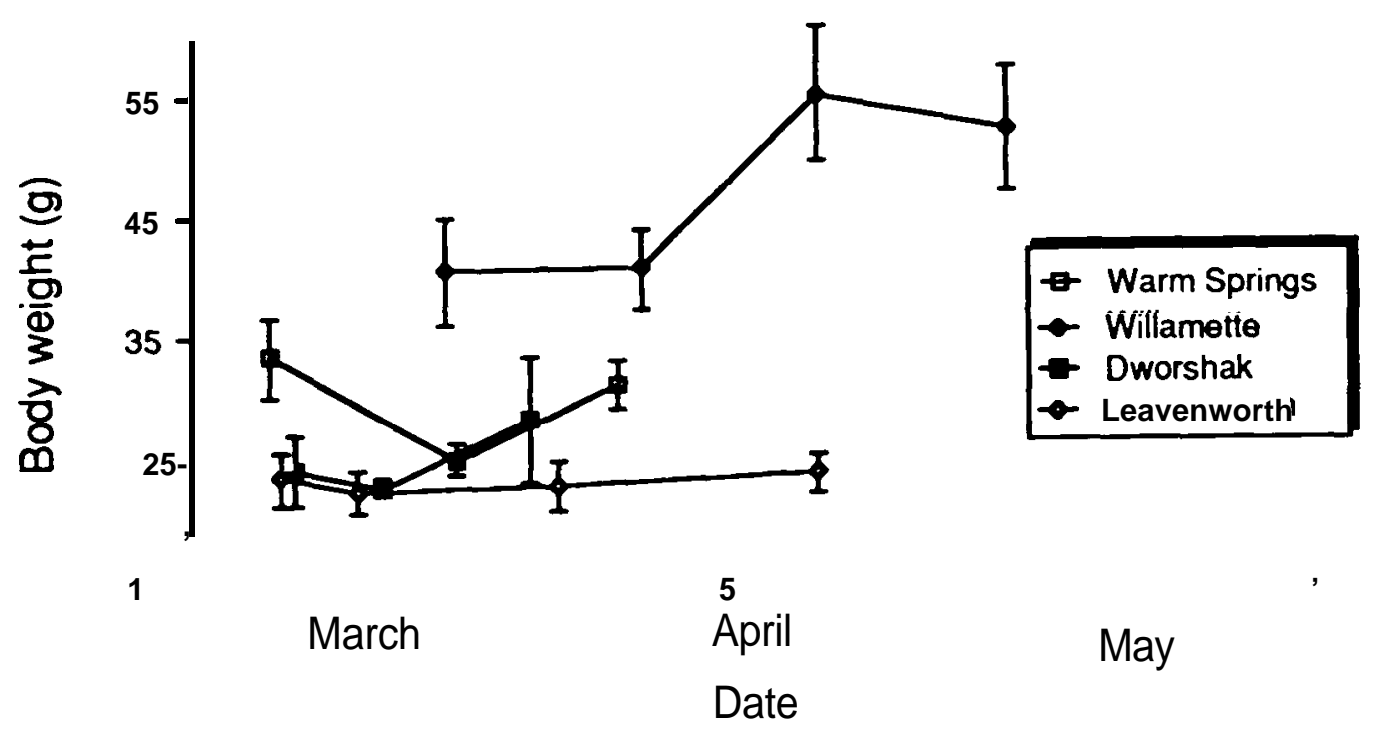

Figure 2.--Mean body weights of fish sampled (Group III) at the four hatcheries indicated. Brackets indicate + one standard error. Data from the same fish shown in Figure 1. 


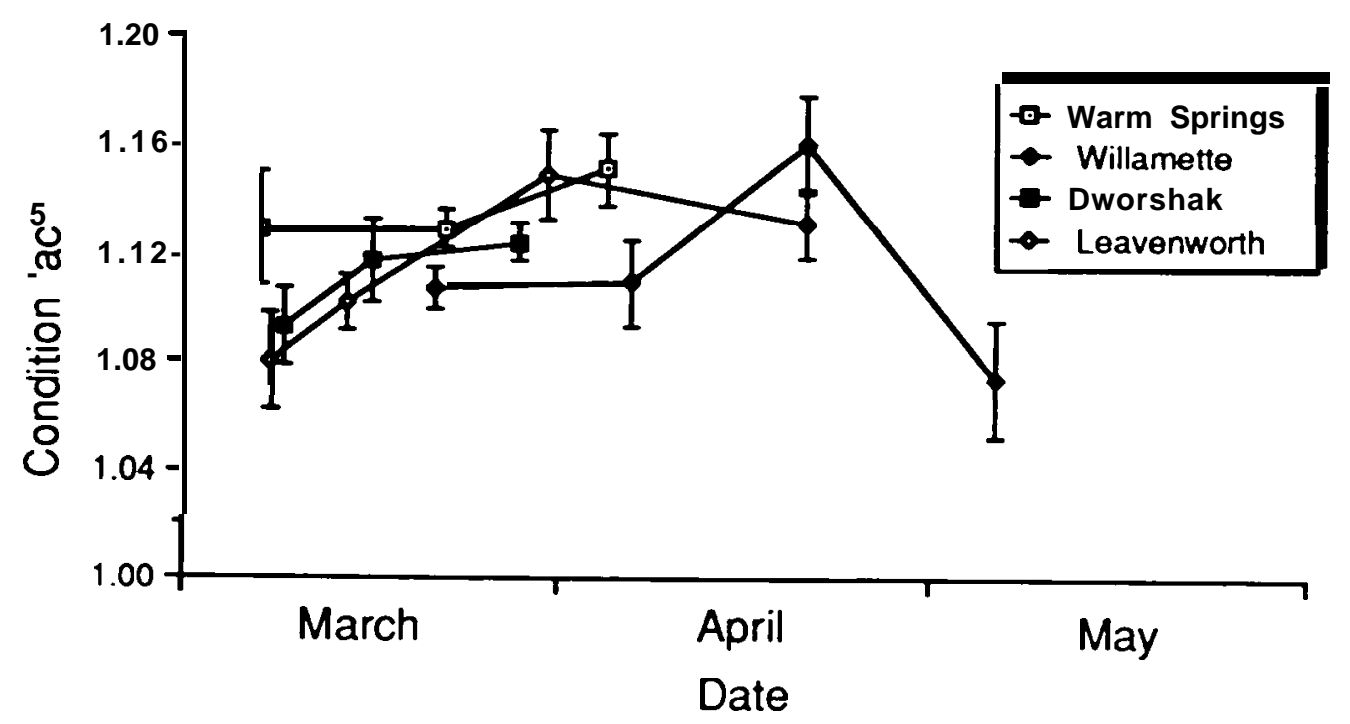

Figure 3.--Mean condition factors of fish sampled (Group III) at the four hatcheries indicated. Brackets indicate \pm one standard error. Data from the same fish shown in Figure 1. 
Saltwater Challenge Test

Saltwater challenge tests were performed shortly before release of the fish from the hatcheries (also 1 month before release at Leavenworth and Willamette Hatcheries).

Samples were taken to determine plasma sodium and potassium concentrations for the control and saltwater-challenged fish at 24 hours after transfer to salt water. Gill ATPase activities were also determined for saltwater-challenged fish. Plasma sodium concentrations and mortalities after saltwater challenge of fish from all hatcheries tested are shown in Figure 4.

Plasma sodium concentrations from all control fish (not exposed to salt water) were below $170 \mathrm{mmol} / \mathrm{L}$, whereas all test groups at 24 hours after saltwater entry had sodium levels above $200 \mathrm{mmol} / \mathrm{L}$. Of the fish transferred to salt water, the highest mean sodium levels were observed in fish from Dworshak Hatchery; the lowest mean sodium levels were observed in fish from Willamette Hatchery. These results suggest that the fish from the Willamette Hatchery developed the greatest saltwater tolerance at the time of release. However, published work on plasma sodium concentrations of fully smolted chinook salmon subjected to seawater challenge indicates that levels should remain below 170 mmol/L (Blackbum and Clarke 1987). This suggests that none of the groups of fish tested in our study were fully smolted, since mean plasma sodium concentrations exceeded 200 $\mathrm{mmol} / \mathrm{L}$ in all groups. On the other hand, in comparison with published studies, the plasma sodium concentrations measured in fish either in salt water or in fresh water are unusually high. An alternative interpretation of these data on plasma sodium is that there may have been some contamination of the blood samples with glassware used at the time of sampling. In support of this possibility of contamination of the plasma samples are our own data on plasma sodium concentrations measured for fish that were in fresh water and were not part of the saltwater challenge. The sodium values for the routinely-sampled fish in fresh water (Group II) were between 150 and $155 \mathrm{mmol} / \mathrm{L}$ (see below), whereas the sodium values for the freshwater control fish in the saltwater-challenge experiment, which were sampled using different glassware than for Group II, were 168, 165, 165, and 152 $\mathrm{mmol} / \mathrm{L}$ for fish from Leavenworth, Dworshak, Willamette, and Warm Springs, respectively. Regardless of the overall high values for plasma sodium in the saltwater challenge. the data are useful for comparisons between hatcheries within the 1989 study, assuming that possible contamination of the samples was uniform in all groups.

A few fish died during the saltwater challenge test (Fig. 4). In the 29 March test at Leavenworth, four fish died during the 24-hour period in saltwater, seven fish died during 


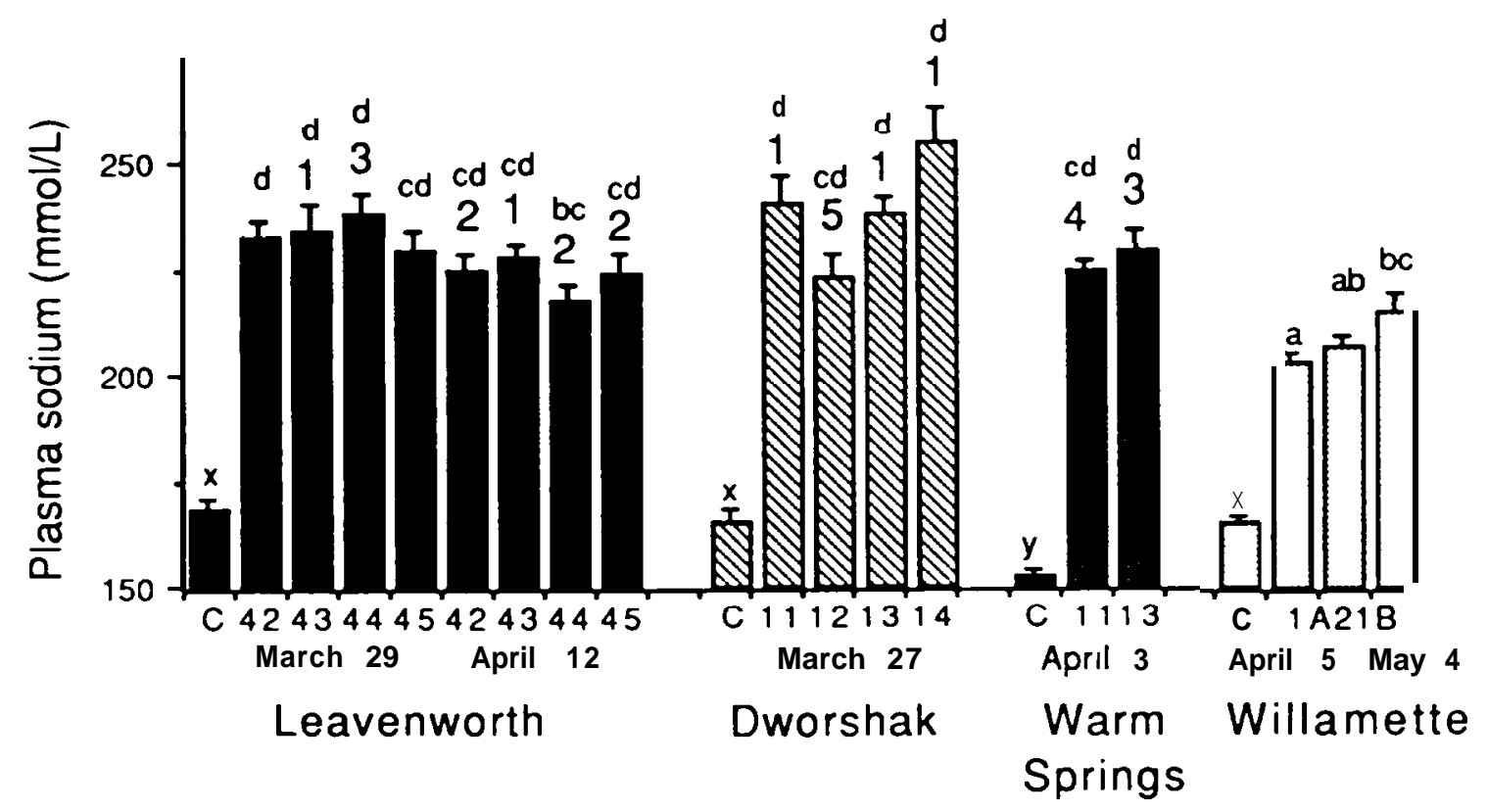

Figure 4.--Mean plasma sodium values for control and saltwater challenged fish from each hatchery. Brackets indicate + one standard error. The letter or number below each column represents control (C) or the raceway number. The number above each bar indicates the number of fish mortalities in that group after the 24-hour period in salt water. The letters above each bar indicate significant differences $(\mathrm{P}<0.05$; ANOVA, Fisher PLSD) in the sodium values. Bars with a common letter are not significantly different. $\mathrm{N}=15$ to 20 fish per bar. 
the 12 April test at Leavenworth; eight fish died in the test on 27 March at Dworshak, and seven fish died during the 3 April test at Warm Springs. In conuast, no fish died at any time during the saltwater challenge tests at Willamette. The incidence of fish mortality is approximately correlated with elevated plasma sodium concentrations in fish at Leavenworth, Dworshak, and Warm Springs Hatcheries.

Plasma potassium concentrations and mortalities after saltwater challenge of fish from all hatcheries tested are shown in Figure 5. The expected result would show that smolts have greater capacity for potassium regulation than parr, although potassium regulation is more variable than sodium regulation in saltwater-challenged fish (Blackbum and Clarke 1987). Most of the test fish at Leavenworth Hatchery had plasma potassium concentrations significantly elevated over that of controls. At all other hatcheries, there were usually no significant differences in plasma potassium between control and treated fish. The potassium values were generally lower in fish from Dworshak, Warm Springs, and Willamette Hatcheries compared to fish from Leavenworth Hatchery. These data suggested that fish at Leavenworth Hatchery were less able to control their plasma potassium levels in comparison to fish at the other hatcheries, which appeared comparable in their capacity for potassium regulation during saltwater challenge. The plasma potassium values for the freshwater controls in the saltwater challenge test were generally higher than those for fish in Group II during routine sampling of production fish (see below). This difference supports our suspicion that the plasma samples from the saltwater challenged fish were slightly contaminated with salt water.

Gill Na+-K+ATPase activities of fish after saltwater challenge are shown in Figure 6. The lowest gill ATPase activities were in fish tested during late March at Leavenworth and Dworshak Hatcheries. The highest activities were found in fish from Willamette Hatchery, particularly those from raceway 21B tested on 4 May. The high ATPase values of fish at Willamette hatchery, their lower plasma sodium (Fig. 4). and their good survival in the saltwater challenge test are suong indicators of good saltwater tolerance of these fish.

Gill ATPase Activity in Fish in Fresh Water

The patterns of gill Na+-K+ ATPase activity for groups of fish at the different hatcheries are shown in Figure 7. The mean gill ATPase activities remained below $15 \mu$ moles Pi/mg protein-hour in all groups at the Dworshak, Leavenworth, and Warm Springs Hatcheries throughout the sampling period; there were no statistically significant differences in any of the groups sampled at these hatcheries. Higher ATPase activities were observed in the two groups of fish at the Willamette Hatchery. Significant increases in ATPase occurred 


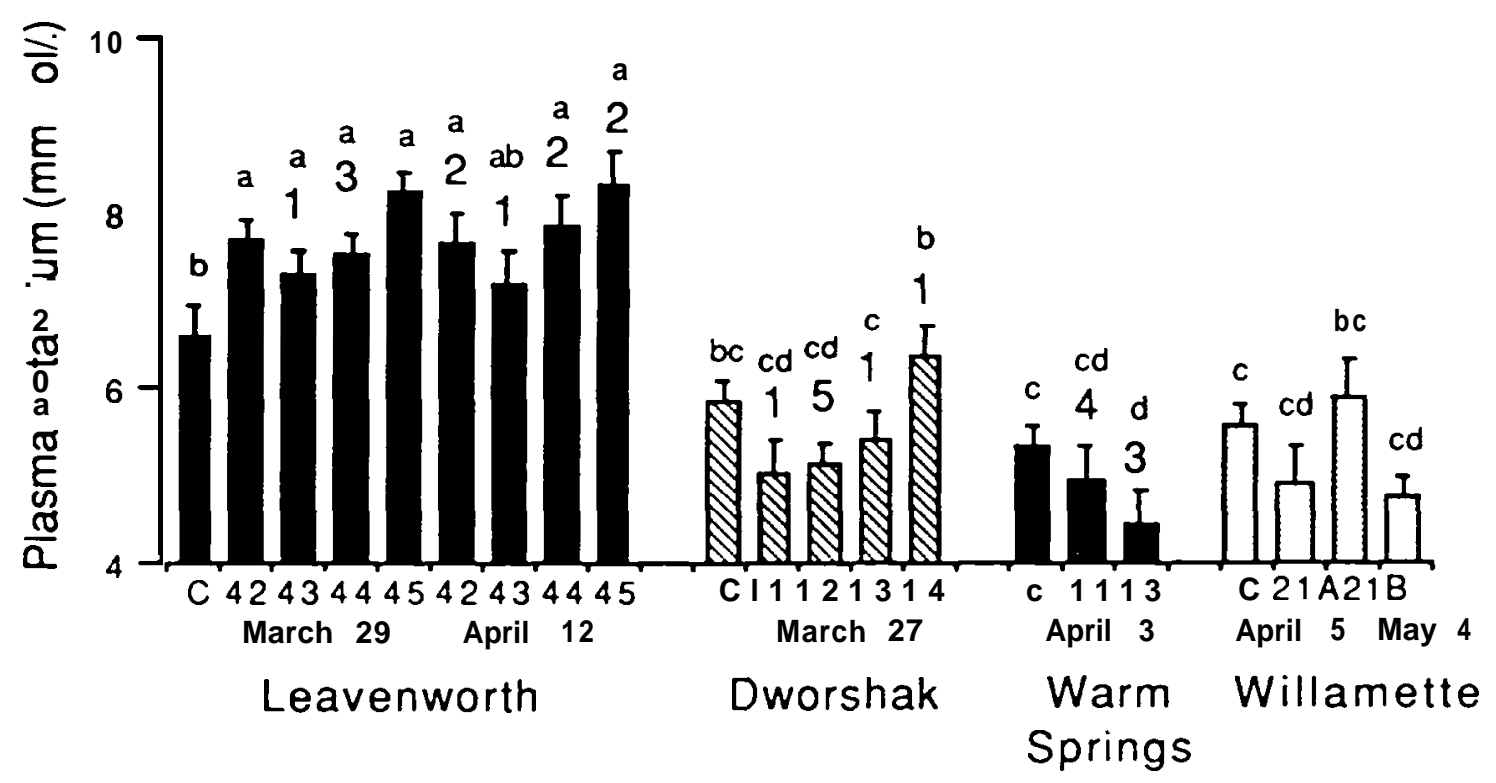

Figure 5.--Mean plasma potassium values for control and saltwater-challenged fish from each hatchery. Brackets indicate + one standard error. The letter or number below each column represent conuol (C) or the raceway number. The number above each bar indicates the number of fish mortalities in that group after the 24-hour period in seawater. The letters above each bar indicate significant differences $(\mathrm{P}<0.05$; ANOVA, Fisher PLSD) in the potassium values. Bars with a common letter are not significantly different. $\mathbf{N}=15$ to 20 fish per bar. 


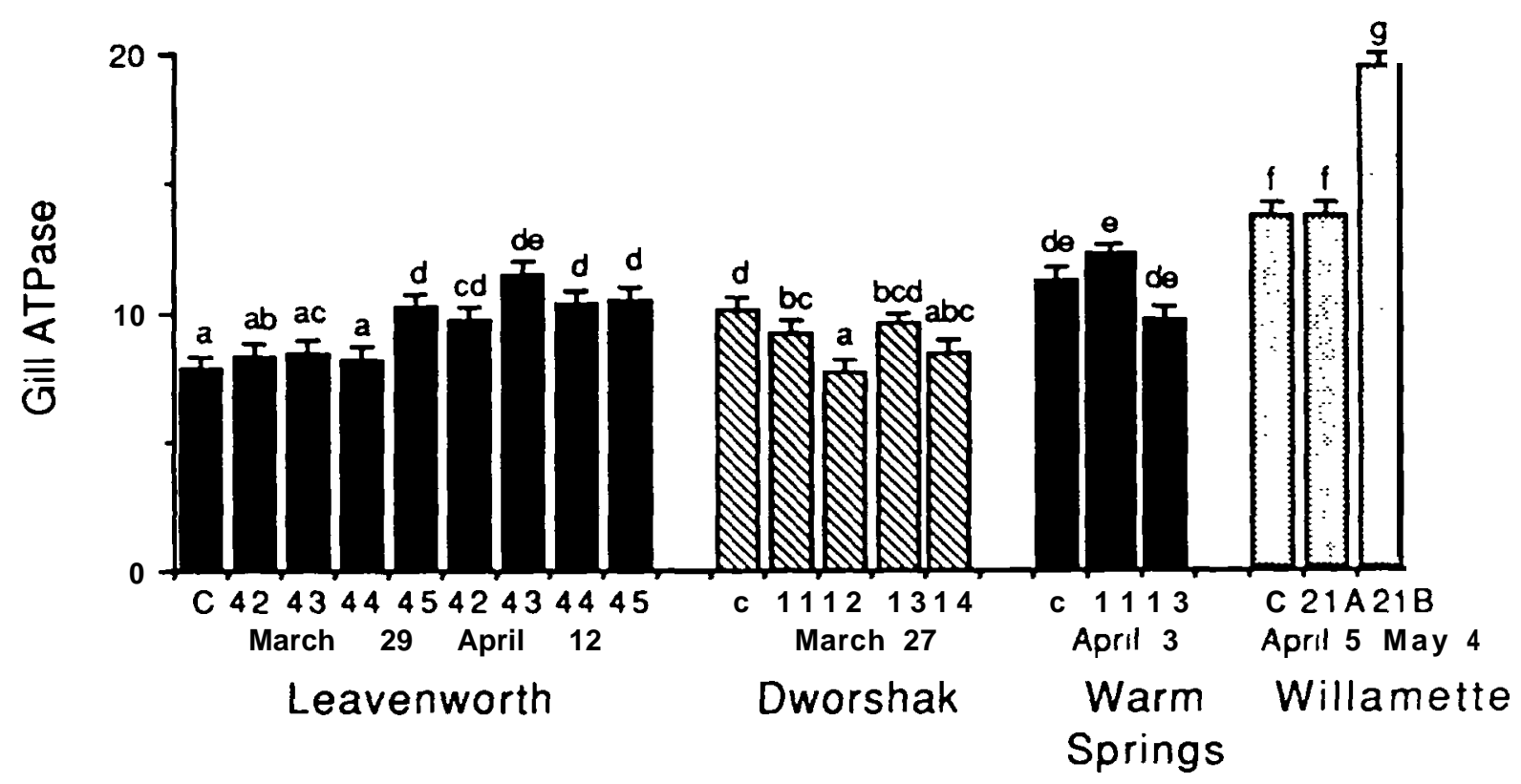

Figure 6.--Mean gill Na+-K+ ATPase values for control and saltwater challenged fish from each hatchery. Gills were sampled after the saltwater challenge. Brackets indicate + one standard error. The letter or number below each column represent control (C) or the raceway number. The letters above each bar indicate significant differences $(\mathrm{P}<0.05$; ANOVA) in the values. Bars with a common letter are not significantly different. $\mathrm{N}=15$ to 20 fish per bar. 

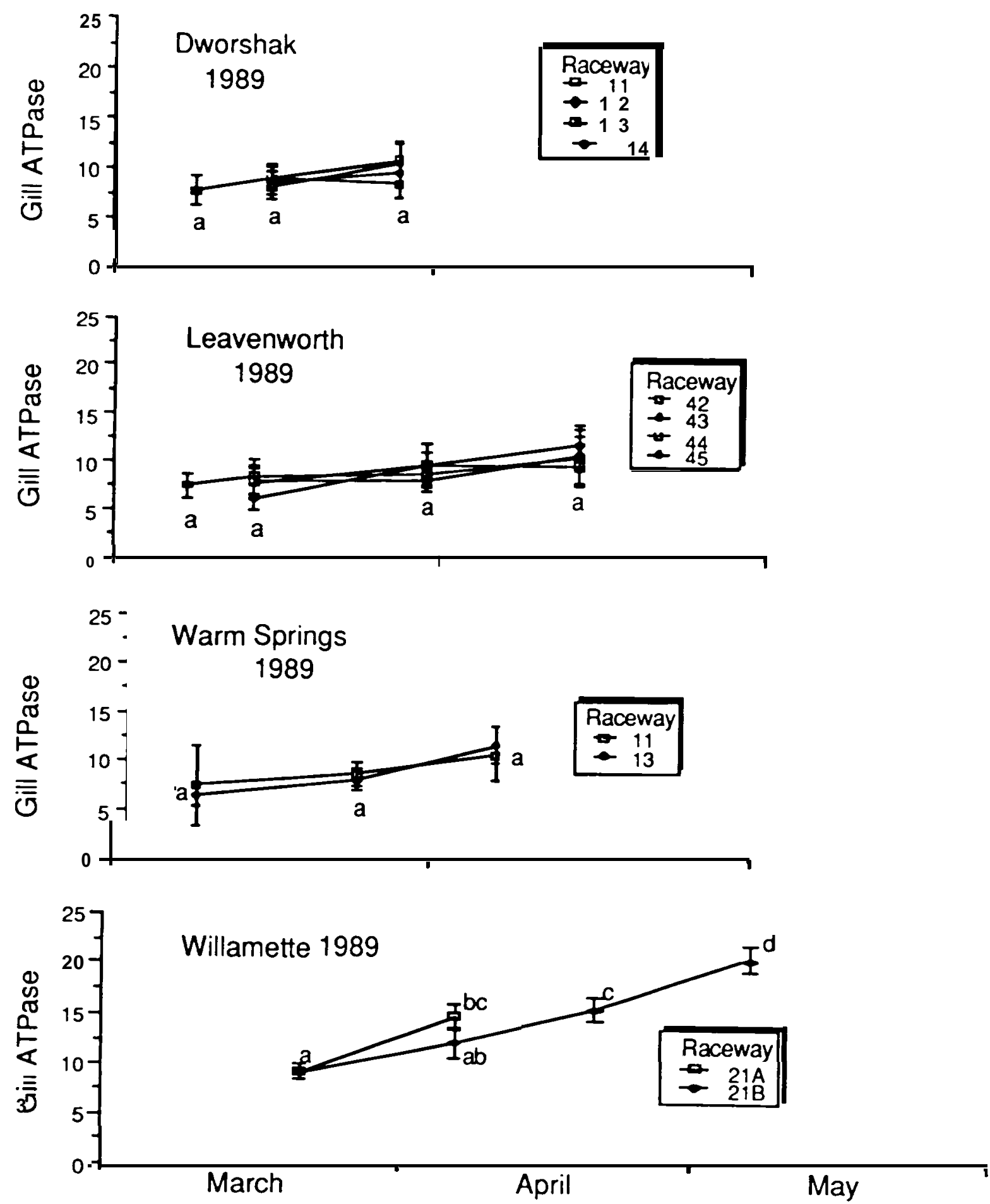

Figure 7.--Gill $\mathrm{Na}^{+}-\mathrm{K}^{+}$ATPase activities ( $\mu$ moles $\mathrm{P}_{\mathrm{i}} / \mathrm{mg}$ protein-hour) for groups of fish sampled at the indicated hatcheries. Symbols indicate means; brackets indicate \pm one standard error. Letters next to the symbols indicate significant differences within a hatchery $(\mathrm{P}<0.05$; ANOVA, Fisher PLSD). Points with a common letter are not significantly different. 
between March and April in the April release group (raceway 2 1A). For the May release group (raceway $21 \mathrm{~B}$ ), significant increases in ATPase were observed during April and May. The May release group at Willamette Hatchery showed the highest ATPase activity at the last sampling date. Since smolting is associated with high ATPase activity (Zaugg and McLain 1972), these data suggested that the greatest smolt development was attained by the May release group at the Willamette Hatchery. In contrast, little or no smolt development was indicated by ATPase activities measured in the groups at the other hatcheries. At the time of release of fish in Dworshak, Leavenworth, and Warm Springs Hatcheries, the mean gill ATPase activities were in the range of 10 to $12 \mu$ moles Pi/mg protein-hour. At the time of release of fish at Willamette Hatchery, mean gill ATPase activities were 14.2 (April release) and 19.8 (May release) $\mu$ moles $\mathrm{Pi} / \mathrm{mg}$ protein-hour.

\section{Plasma Hormone Concenuations}

Plasma concentrations of thyroid hormones, insulin, and cortisol are shown in Figures 8 through 11 for fish sampled at the different hatcheries.

The plasma concentrations of thyroid hormones, thyroxine (T4) and triiodothyronine (T3), are shown in Figures 8 and 9, respectively. The mean levels of T4 showed an increasing trend in most fish sampled at the Dworshak Hatchery. There was a small but significant peak in plasma T4 occurring in mid-March in fish in raceway 14 at Dworshak. At Leavenworth Hatchery, the initial sample (7 March) was from raceway 49.

Subsequently, the mean T4 levels co-varied in pairs of raceways; values from raceways 42 and 43 were similar and higher than those from raceways 44 and 45 on 14 and 29 March. On the last sampling date, 14 April, T4 values from raceways 44 and 45 were similar and higher than those from raceways 42 and 43 . This pattern of variation was probably due to differing times of the day when the blood samples were taken. Raceways 42 and 43 were sampled in the afternoon on 14 and 29 March, whereas they were sampled in the morning on 14 April. Raceways 44 and 45 were sampled in the morning on 14 and 29 March, whereas they were sampled in the afternoon on 14 April. Daily fluctuations in T4 levels in salmonids are well-known (Eales et al. 1981; Laidley and Leatherland 1988). For the Leavenworth fish, however, there was a decreasing trend in T4 levels. At Warm Springs Hatchery, T4 levels were initially high in both groups; levels declined significantly in the subsequent samples. It was noted at the time of the first sampling at Warm Springs that the hatchery water was unusually silted. A large amount of silt had just appeared in the water at the time the sampling crew arrived at the hatchery. If the fish sensed this siltation as novel fresh water, then the relatively high T4 levels measured in the first sampling point at 

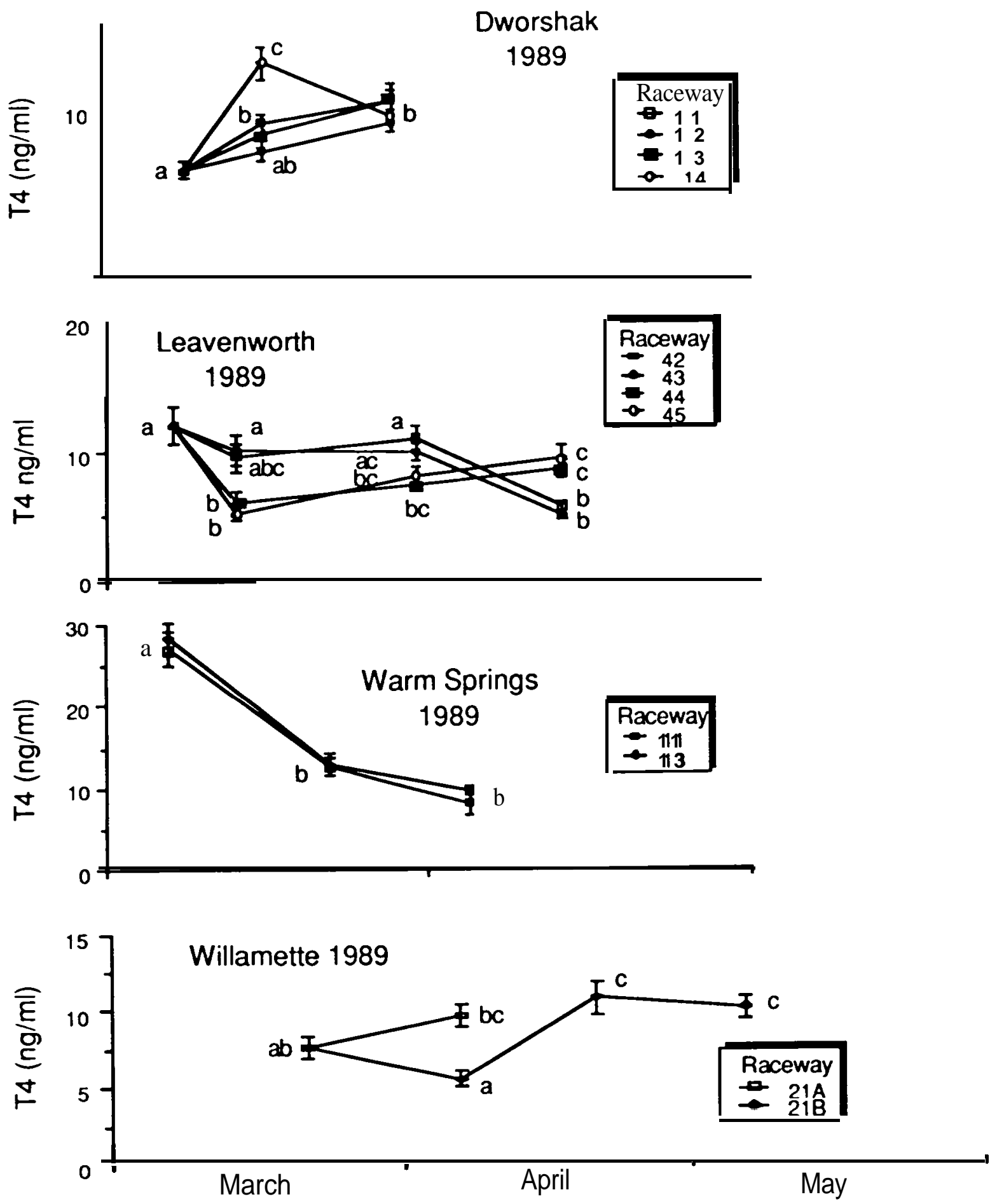

Figure 8.--Plasma concentrations of thyroxine (T4) in sampled fish at the indicated hatcheries. Symbols indicate means; buckets indicate $t_{-}$one standard error. Letters next to the symbols indicate significant differences within a hatchery $(\mathrm{P}<0.05 ;$ ANOVA, Fisher PLSD). Points with a common letter are not significantly different. 

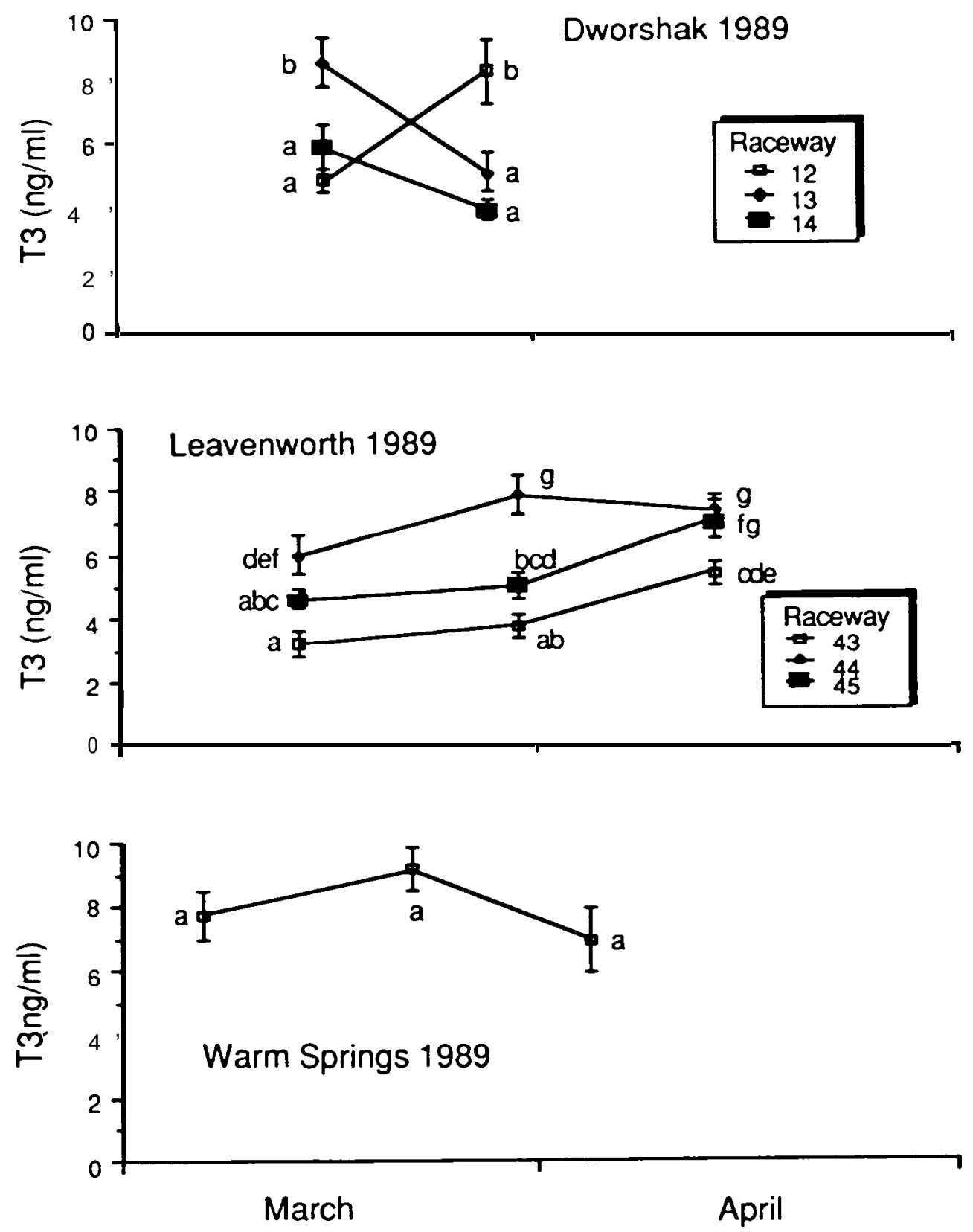

Figure 9.--Plasma concentrations of triiodothyronine (T3) in sampled fish at the indicated hatcheries. Symbols indicate means; brackets indicate \pm one standard error. Data for Willamette Hatchery are reported in the text. Letters next to the symbols indicate significant differences within a hatchery $(\mathrm{P}<0.05$; ANOVA, Fisher PLSD). Points with a common letter are not significantly different. 

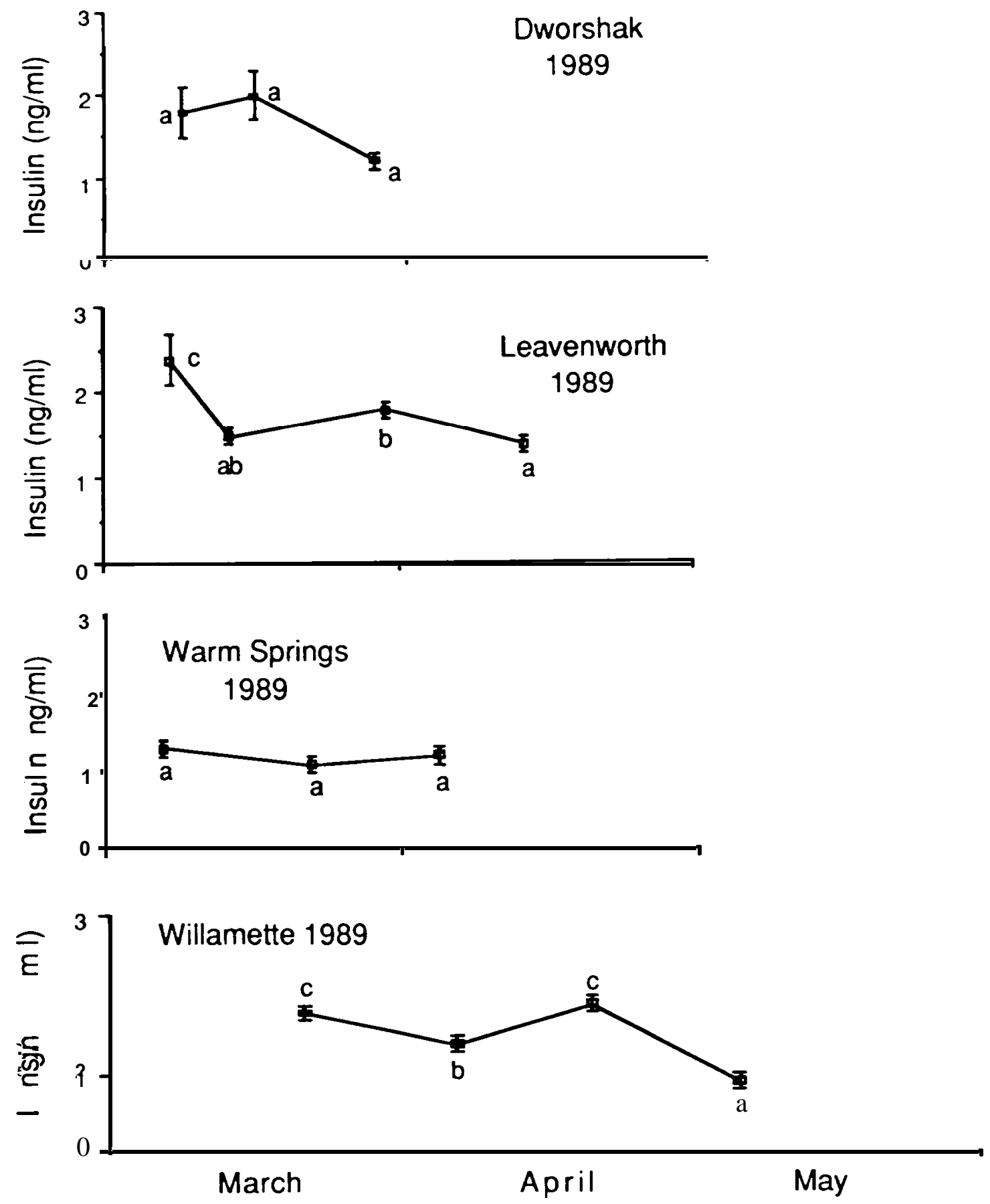

Figure 10.--Plasma concentrations of insulin in sampled fish at the indicated hatcheries. Symbols indicate means; brackets indicate \pm one standard error. Letters next to the symbols indicate significant differences within a hatchery ( $<<0.05$; ANOVA, Fisher PLSD). Points with a common letter are not significantly different. 

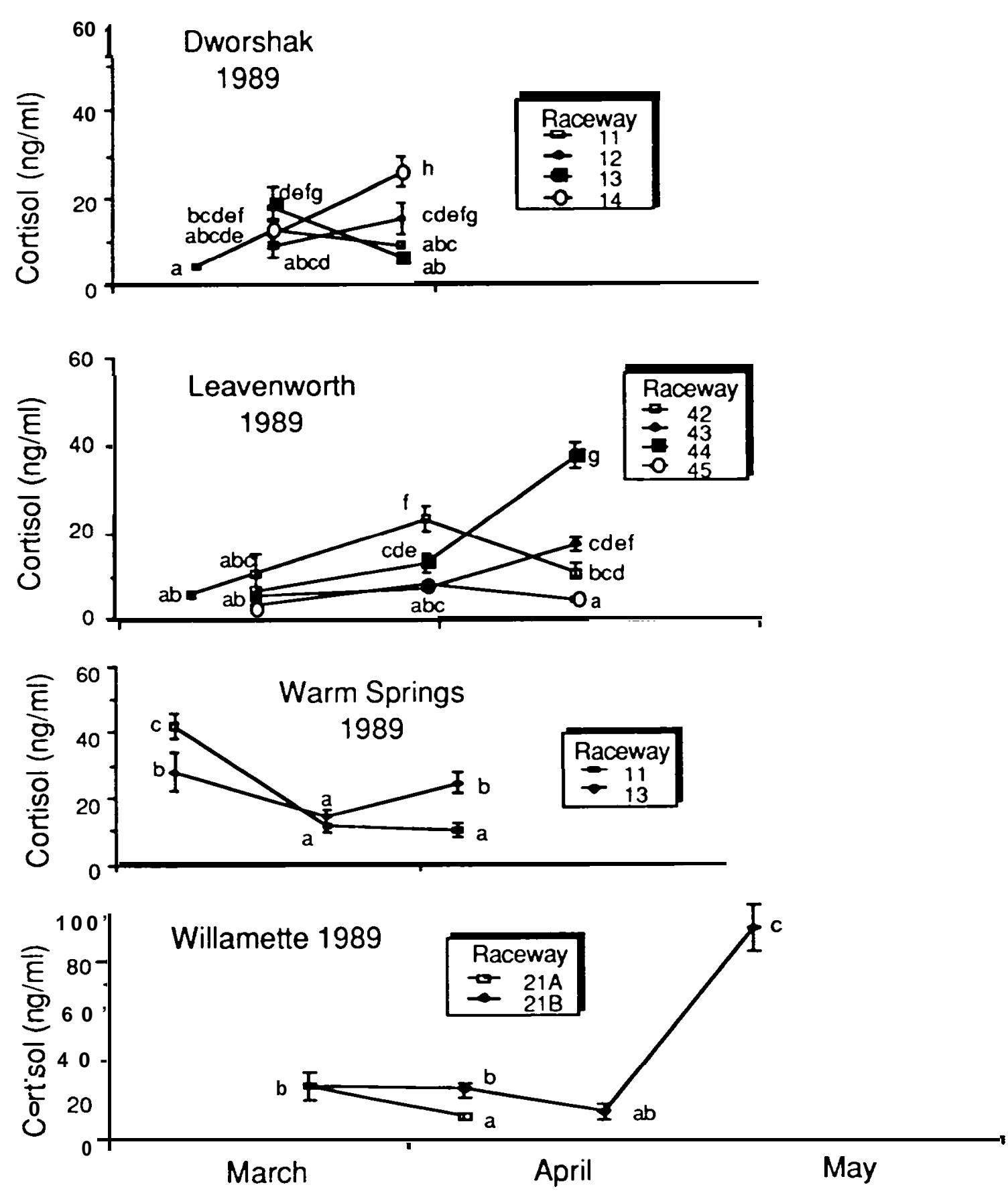

Figure 11.--Plasma concentrations of cortisol in sampled fish at the indicated hatcheries. Symbols indicate means; brackets indicate \pm one standard error. Letters next to the symbols indicate significant differences within a hatchery ( $\mathrm{P}<0.05$; ANOVA, Fisher PLSD). Points with a common letter are not significantly different. 
Warm Springs may not be resting levels of T4. The basis for this speculation is the observation that novel fresh water causes a transient elevation in blood levels of T4 in salmon during smoltification (Dickhoff et al. 1982a; Nishioka et al. 1985). Presumably the novel freshwater response in T4 is olfactory-mediated, and may be involved in homing imprinting. At Willamette Hatchery, T4 levels were highest in the late April and early May samples for raceway $21 \mathrm{~B}$ (Fig. 8). In general, T4 levels increased during the sampling period in Dworshak and Willamette fish, and decreased in Leavenworth and Warm Springs fish. The clearest indication of an expected increase in T4 was observed in the Willamette fish in raceway $21 \mathrm{~B}$.

At Dworshak Hatchery, mean plasma T3 levels decreased during March in fish in raceways 13 , increased in fish in raceway 12 , and showed no significant change in fish in raceway I4 (Fig. 9). At Leavenworth Hatchery, T3 levels increased in fish in all raceways, and there were consistent differences among the raceways sampled. Consistently higher mean T3 levels were observed in fish from raceways 43,45 and 44, progressively. Mean T3 levels in the fish at Warm Springs (raceway 13) were constant between mean values of 6.7 and $8.9 \mathrm{ng} / \mathrm{ml}$. The data on T3 levels in fish at Willamette Hatchery are available only for raceway 11 on 4 April due to a problem with processing the samples in the laboratory. However, the mean was 10.1 with a standard error of 0.6 ; this was the highest value for T3 of all groups sampled.

Plasma insulin concentrations are shown in Figure IO. At Dworshak Hatchery (raceway 1 1), mean plasma insulin levels showed no significant change, and remained within the 1 to $2 \mathrm{ng} / \mathrm{ml}$ range. At Leavenworth Hatchery (raceway 42), mean plasma insulin declined from an initial high of $2.3 \mathrm{ng} / \mathrm{ml}$ to I $.4 \mathrm{ng} / \mathrm{ml}$ during March and then remained relatively constant in subsequent samples. There was no significant change in plasma insulin in fish at Warm Springs Hatchery (raceway 1 I) throughout the sampling period. Plasma insulin was relatively high in the first three sampling periods in fish at Willamette (raceway $21 \mathrm{~B}$ ), and then it declined to a low of $0.8 \mathrm{ng} / \mathrm{ml}$ in fish near the time of release. In coho salmon, insulin levels decline from levels ranging from 1.5 to $7 \mathrm{ng} / \mathrm{ml}$ in parr to levels in the range of 0.7 to $1 \mathrm{ng} / \mathrm{ml}$ just prior to smoltification (Plisetskaya et al. 1988). These data suggest that smoltification is beginning in the fish at Willamette and Leavenworth Hatcheries, but not at Dworshak and Warm Springs Hatcheries.

Alternatively, the lack of change in insulin levels in fish at Dworshak and Warm Springs may be due to infrequent sampling. The lowest mean insulin levels were observed in fish near the time of release from Willamette Hatchery, suggesting that these fish were the most advanced in smolting. 
Resting (presumably non-stress) levels of plasma cortisol are shown in Figure 11. At Dworshak Hatchery, there was an increase in mean plasma cortisol in fish sampled after the initial sampling. By the last sampling date at Dworshak, plasma conisol was significantly elevated over initial levels only in sampled fish in raceways 12 and 14. At Leavenworth Hatchery, mean plasma cortisol showed significant increases during the sampling period in fish in raceways 42,43 and 44 ; there was no significant change in plasma cortisol in fish in raceway 45. Highest mean plasma cortisol was observed at the time of release of fish in raceways 43 and 44. At Warm Springs Hatchery, the mean levels of cortisol were initially elevated (20 to $50 \mathrm{ng} / \mathrm{ml}$ ); they declined in the subsequent sampling periods. At the time of release, mean plasma cortisol was higher in fish in raceway 13 compared to raceway 11 . It was noted at the time of the first sampling at Warm Springs that the hatchery water was unusually silted. A large amount of silt had just appeared in the water at the time the sampling crew arrived at the hatchery. At high levels of silting, conisol levels may be elevated (Redding et al. 1987). If the fish sensed this siltation as a stressor, then the relatively high cortisol IeveIs measured in the first sampling point at Warm Springs may not be resting levels of cortisol. At Willamette Hatchery, mean plasma cortisol showed a declining tendency from March to April; there was a marked elevation in cortisol at the time of release of fish in May. At the time of the last sampling of fish at Willamette, the pond containing the fish had been drained to one-half capacity in preparation for release of the fish. The sampling crew observed the fish in the low water conditions, and concluded that the fish were agitated. The relatively high levels of cortisol in the May samples at Willamette are comparable to cortisol levels in acutely stressed fish, and probably reflect stress levels and not resting levels. In general, elevated levels of cortisol were observed in fish at all hatcheries. There was little consistency comparing cortisol levels in fish in different raceways within a hatchery on the same sampling date, but this may have been due to occasional activity of hatchery personnel in adjacent raceways. Since significant elevation in plasma cortisol is often observed in salmonids during smoltification, these results suggested that only the fish in the May release group at Willamette and some fish at Leavenworth and Dworshak showed typical indications of smolting (Patiño et al. 1986). However, in view of the probability that the fish in the May sample at Willamette were stressed, no clear conclusions can be made regarding the degree of smolting based on resting cortisol levels of the various groups. 
Secondary Stress

Fish were subjected to a secondary stress test comprised of I hour of confinement in a bucket suspended in the raceway. Blood plasma cortisol was measured as an indicator of the stress response. Plasma cortisol concentrations after stress are shown in Figure 12. At both Dworshak and Leavenworth Hatcheries, mean plasma cortisol levels were usually in the range of 60 to $120 \mathrm{ng} / \mathrm{ml}$ throughout the sampling period, and there was no consistent trend toward increasing or decreasing cortisol values. At both Warm Springs and Willamette Hatcheries, stress levels of cortisol showed an increasing trend over time. An increase in stress-induced cortisol levels as smoltification progresses is anticipated based on work that demonstrated an increasing sensitivity of cortisol production by the interrenal tissue in response to adrenocorticotropic hormone (ACTH; Young 1986). It is interesting to note that at Warm Springs Hatchery, fish at low density (raceway 11) had significantly lower stress levels of cortisol during the earliest stress treatment. Differences between stress-induced cortisol levels disappeared in subsequent tests of fish at Warm Springs. At the time of release of Warm Springs fish, and for the May release group at Willamette, mean cortisol levels after stress went above $150 \mathrm{ng} / \mathrm{ml}$.

Blood glucose levels in fish subjected to stress are shown in Figure 13. Overall, blood glucose values ranged from 81 to $190 \mathrm{mg} / \mathrm{dL}$. The ranges in plasma glucose (mg/dL) for each hatchery were: Dworshak, 81 to 190; Leavenworth, 88 to 176; Warm Springs, 87 to 125; Willamette, 96 to 140 . These ranges in plasma glucose in stressed fish are 30 to 45 $\mathrm{mg} / \mathrm{dL}$ higher than the ranges in plasma glucose for unstressed fish (compare with Fig. 14). There was no consistent trend toward increasing or decreasing blood glucose in the data at any hatchery during the sampling period. In general, the highest plasma glucose levels in response to stress were observed in fish at Leavenworth Hatchery.

Metabolic Indicators

Increased metabolic rate during smolting is associated with declines in metabolic stores of glycogen and lipid (Hoar 1988). Blood plasma glucose levels would not be expected to change if the fish are not stressed and are maintained on an adequate dietary ration. The metabolic state of the fish was evaluated by measuring blood glucose and liver glycogen and triglyceride concentrations. For this evaluation, fish were sampled shortly before release from the hatcheries (also 1 month before release at Leavenworth and Willamette Hatcheries). 

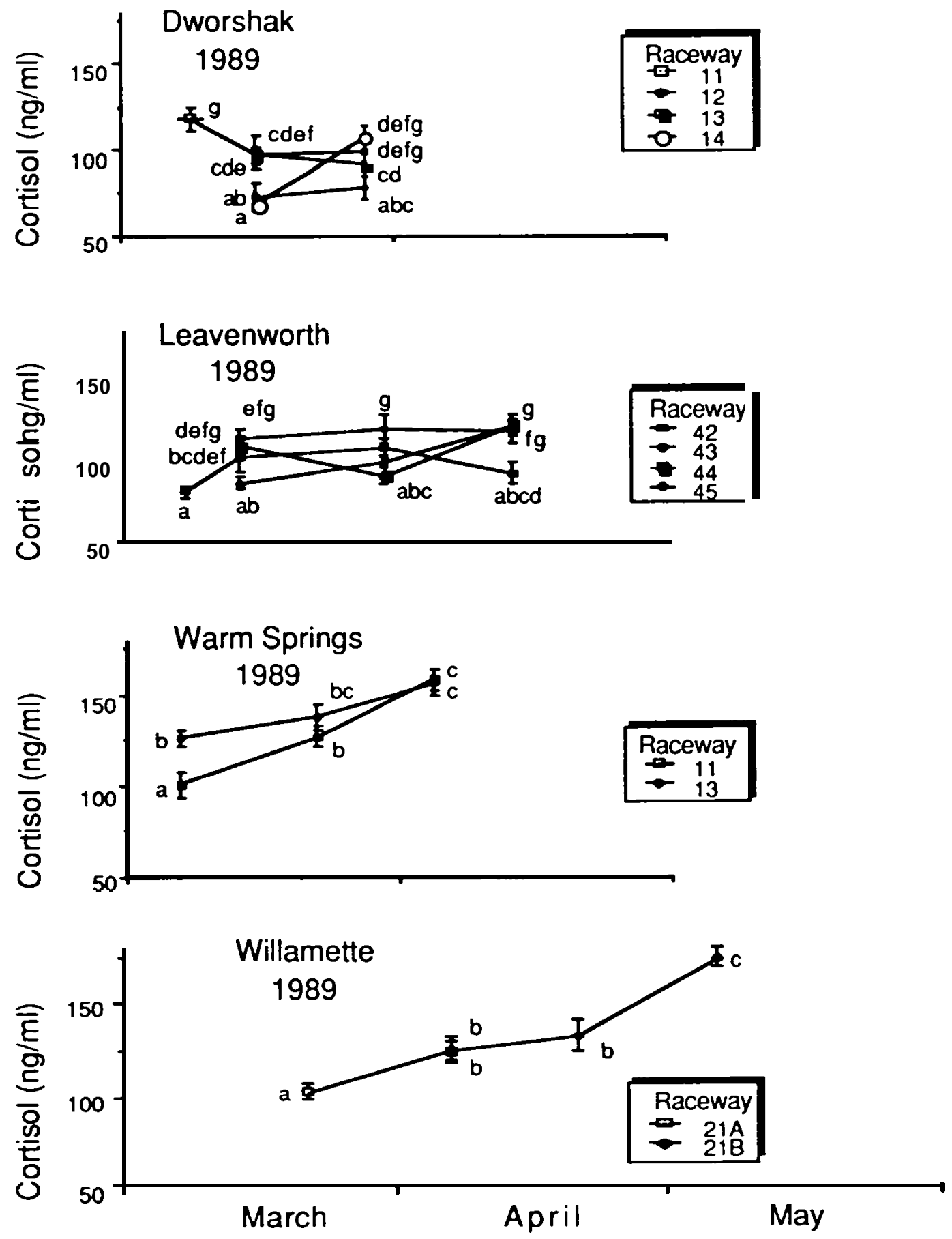

Figure 12.--Plasma concentrations of cortisol in fish subjected to confinement stress at the indicated hatcheries. Symbols indicate means; brackets indicate \pm one standard error. Letters next to the symbols indicate significant differences within a hatchery $(\mathrm{P}<0.05$; ANOVA, Fisher PLSD). Points with a common letter are not significantly different. 

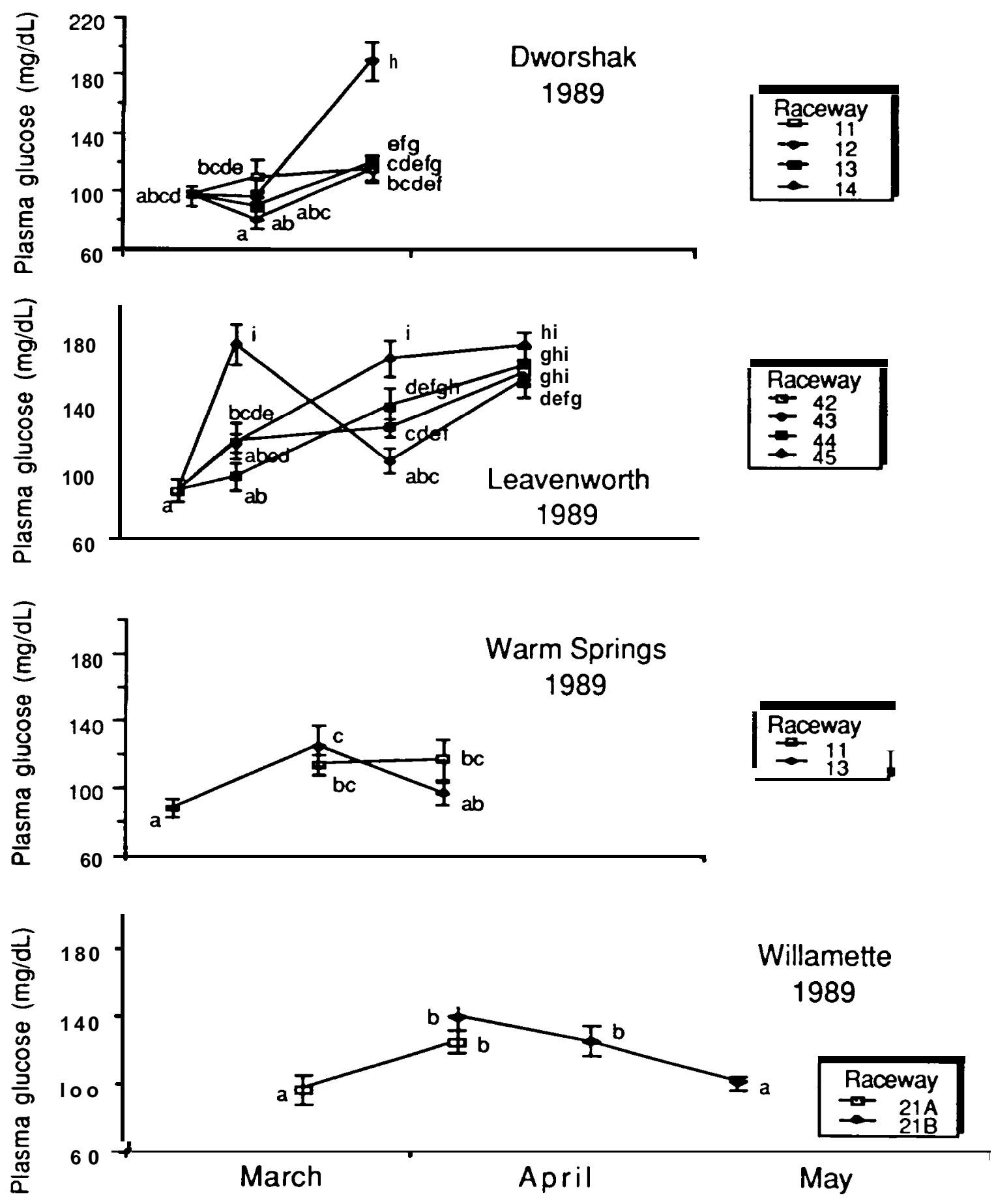

Figure 13.--Plasma concentrations of glucose in fish subjected to confinement suess at the indicated hatcheries. Symbols indicate means; brackets indicate \pm one standard error. Letters next to the symbols indicate significant differences within a hatchery $(\mathrm{P}<0.05$; A.NOVA, Fisher PLSD). Points with a common letter are not significantly different. 
Plasma glucose - - Plasma concentrations of glucose in fish that were not subjected to stress are shown in Figure 14. Plasma glucose ranged from 50 to $160 \mathrm{mg} / \mathrm{dl}$. For fish from individual hatcheries, the ranges in plasma glucose $(\mathrm{mg} / \mathrm{dl})$ were: Dworshak, 61 to 145; Leavenworth, 52 to 144; Warm Springs, 50 to 132; Willamette, 73 to 133. In general, there was no consistent uend toward increasing or decreasing concentrations of plasma glucose over time. The observed ranges in plasma glucose are approximately 30 to $45 \mathrm{mg} / \mathrm{dl}$ below those observed in fish subjected to confinement stress (Fig. 13). Furthermore, it is interesting to note that at Warm Springs Hatchery, plasma glucose concentrations were lower in fish held at low density compared to those held at normal density. These results suggested that fish sampled for evaluation of metabolic state were not exceptionally stressed.

Liver glycogen - - The expected pattern of change in liver glycogen during smolting is a decrease over time from relatively high levels accumulated in parr prior to smolting. The highest mean glycogen concentrations were found in the fish sampled in March at Leavenworth and Dworshak Hatcheries (Fig. 15). There was a slight decline in mean liver glycogen in fish at Leavenworth between March and April sampling dates, but this decline was statistically significant only for fish in raceway 43 . Liver glycogen was relatively low in fish sampled at Warm Springs and Willamette Hatcheries during March. Considering the sampling dates closest to the time of release only, the lowest mean glycogen was found in Willarnette fish in raceway 21B; the next lowest glycogen was observed in Warm Springs fish. These data suggested that the May release fish at Willamette Hatchery were the most advanced in smolting at the time of release.

Liver triglyceride - - The expected pattern of change in liver triglyceride concentration during smolting is a decrease from relatively high levels accumulated in parr prior to smolting. In general, for the fish sampled, there was a trend of decreasing liver triglyceride over time (Fig. 16). The highest mean concenuation of triglyceride was found in the groups of fish sampled at the Leavenworth Hatchery on 13 March. At Leavenworth, there was a significant decline in triglyceride comparing the March and April values. Concenuations of triglyceride in the fish sampled at Dworshak Hatchery in March, and at Willamette Hatchery in May, were less than half those observed in the fish at Leavenworth in March. The lowest mean liver triglyceride was observed in Willamette fish in raceway 21B on 4 May. Considering the sampling dates closest to the time of release only, low liver triglyceride concentrations were found in Willamette (May release) and 

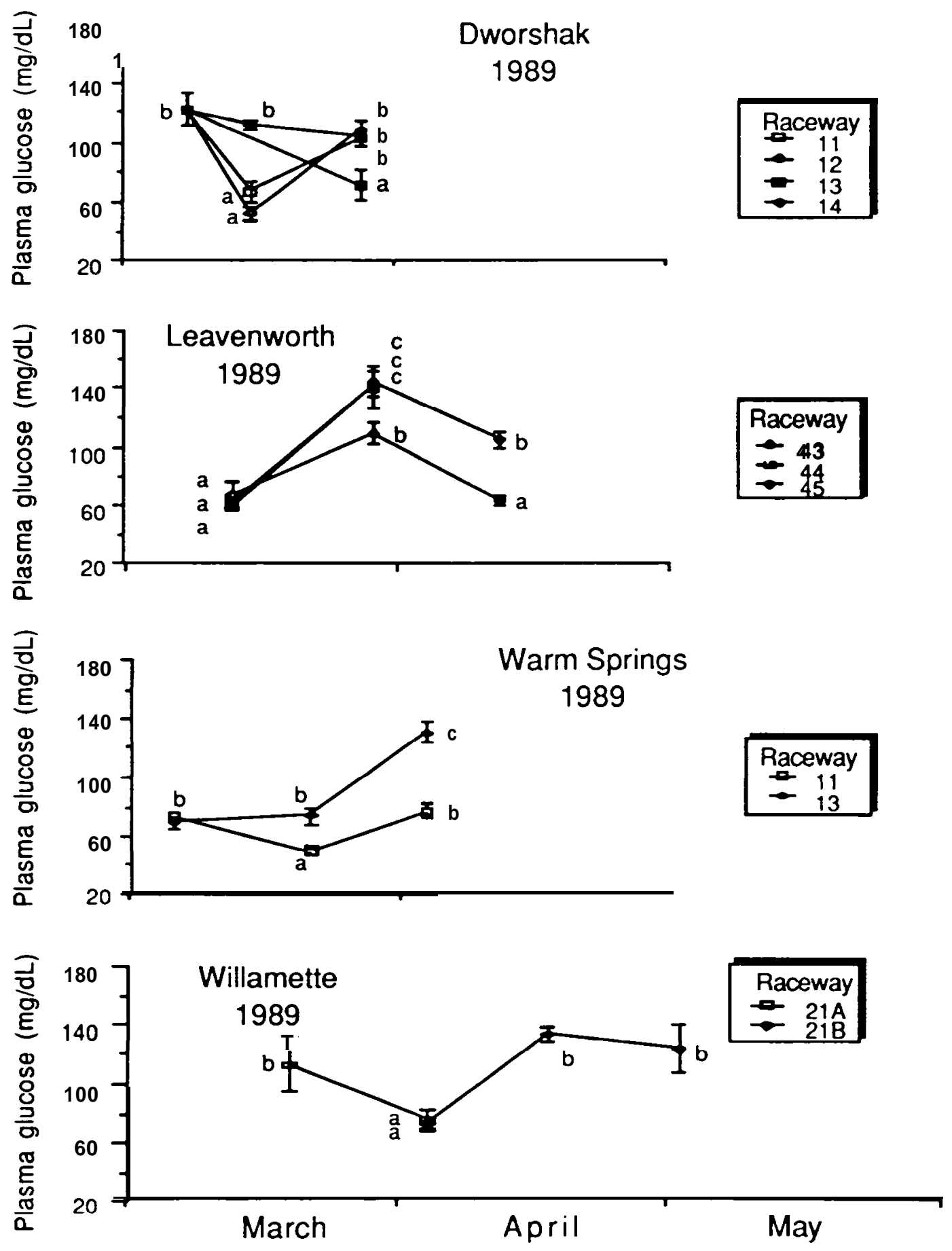

Figure 14.--Plasma concentrations of glucose in unstressed fish at the indicated hatcheries. Symbols indicate means; brackets indicate \pm one standard error. Letters next to the symbols indicate significant differences within a hatchery $(\mathrm{P}<0.05$; ANOVA, Fisher PLSD). Points with a common letter are not significantly different. 


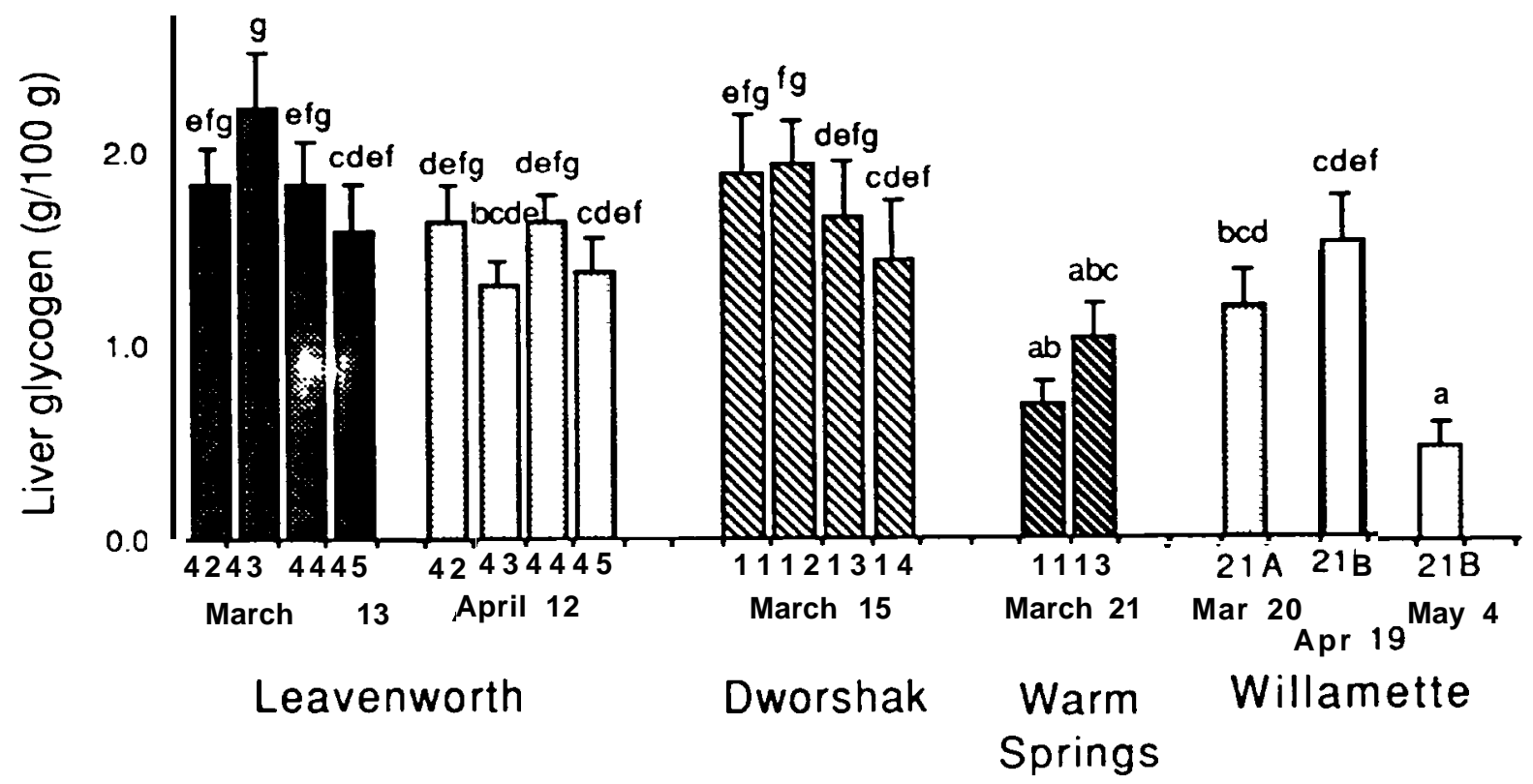

Figure 15.--Liver glycogen content $(\mathrm{g} / 100 \mathrm{~g})$ of fish at the indicated hatcheries. Vertical bars indicate means; brackets indicate + one standard error. The numbers below the bars indicate raceway number and date of sampling. Letters above bars indicate significant differences $(\mathrm{P}<0.05$; ANOVA, Fisher PLSD). Bars with a common letter are not significantly different. 


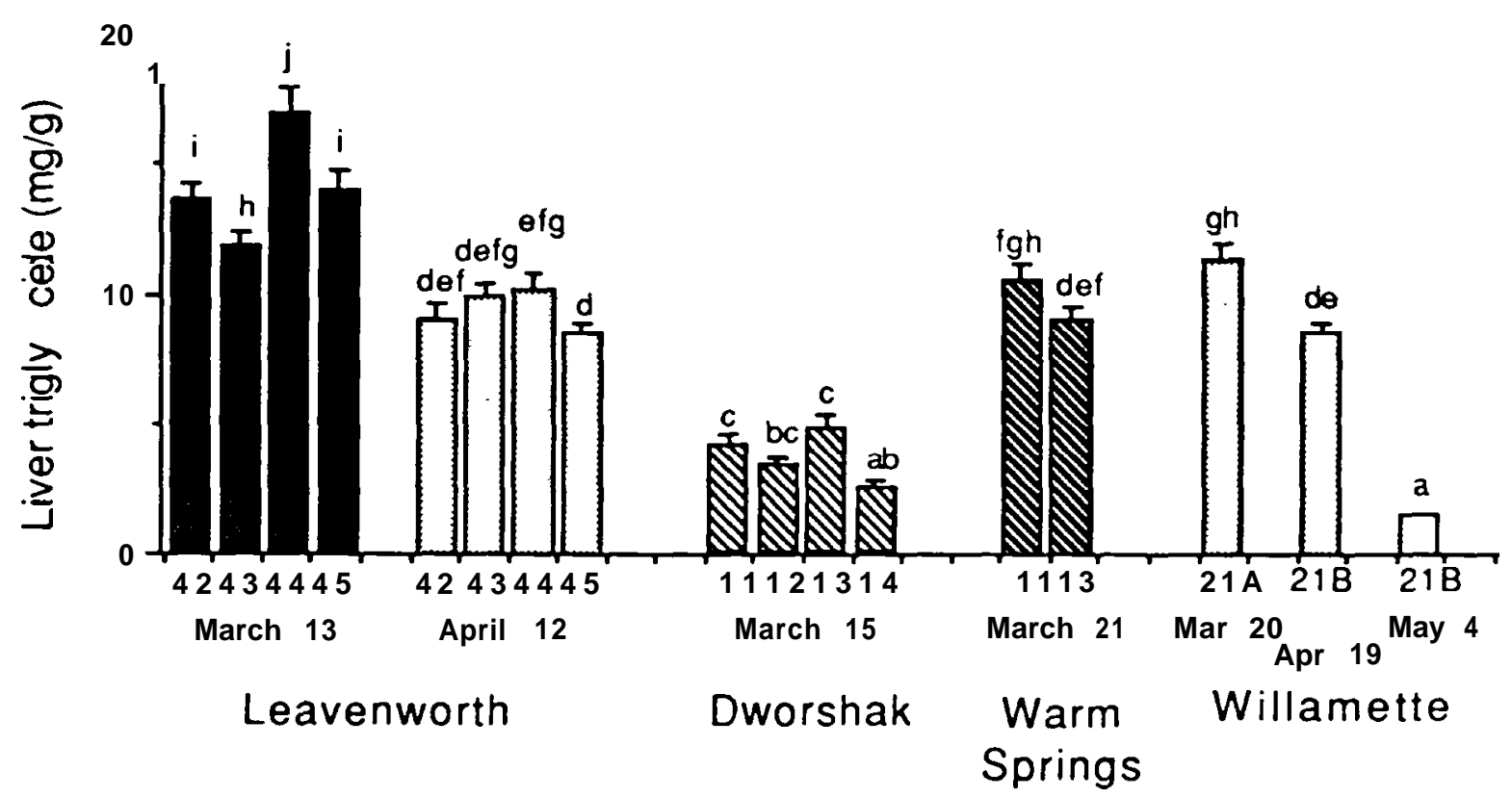

Figure 16.-- Liver triglyceride content $(\mu \mathrm{g} / \mathrm{mg})$ of fish at the indicated hatcheries. Vertical bars indicate means; brackets indicate + one standard error. The numbers below the bars indicate raceway number and date of sampling. Letters above bars indicate significant differences ( $\mathrm{P}<0.05$; ANOVA, Fisher PLSD). Bars with a common letter are not significantly different. 
Dworshak fish. At the time of release, triglyceride levels were approximately equivalent in fish at Leavenworth, Warm Springs, and Willamette (April release) Hatcheries.

Morphological Indicators

Characteristic morphological changes in fish during smoltification include streamlining of body shape and increase in silver color of the skin (silvering is due to guanine deposition). These parameters were evaluated using morphometric analysis and skin guanine concentration determined shortly before release from the hatcheries (also 1 month before release at Leavenworth and Willamette Hatcheries).

Morphometrics - -The change in body shape of the fish sampled was analyzed by determining PC values (Winans 1984). The criterion for smolts according to PC analysis is a reduction of the value to less than zero. The results are shown in Figure 17. At Dworshak Hatchery there was a decreasing trend in mean PC measurements in all groups. The values went from an initial point of 1 to 0 in two groups, and from 1 to -1 for the fish in raceway 14. At Dworshak, only the group in raceway 14 had PC values significantly below zero. However, approximately half of the fish in raceway 14 had been freezebranded, a stressful procedure that may have affected their health. In support of this notion, these fish had elevated cortisol (Fig. 11). At Leavenworth Hatchery the mean PC values varied between 0.5 and -1 in all groups, and there was no consistent increasing or decreasing trend. At Leavenworth, fish in raceways 42 and 43 had PC values significantly below zero on 13 March. At Warm Springs, the mean PC values varied between 0.5 and 0.5 , and there was no marked trend. The only PC value significantly below zero was for fish in raceway 11 on 21 March. At Willamette Hatchery, mean PC values increased from initial values and then declined. There was no point at which the PC values were significantly below zero for fish at Willamette.

Skin guanine - - Mean skin guanine content was highest in fish sampled at Willamette Hatchery in March and April, but it was the lowest of all groups sampled in raceway 21B on 4 May at Willamette Hatchery (Fig. 18). In Leavenworth fish, there was a trend of increasing skin guanine from the March to the April sampling dates, although the increase was significant only for fish in raceway 44. Considering only the March sampling dates for all hatcheries, the highest to the lowest mean skin guanine contents were observed in Willamette, Dworshak, Warm Springs, and Leavenworth, respectively. Since silvering of the skin is due to guanine deposition, a characteristic of smolting, it could be speculated 

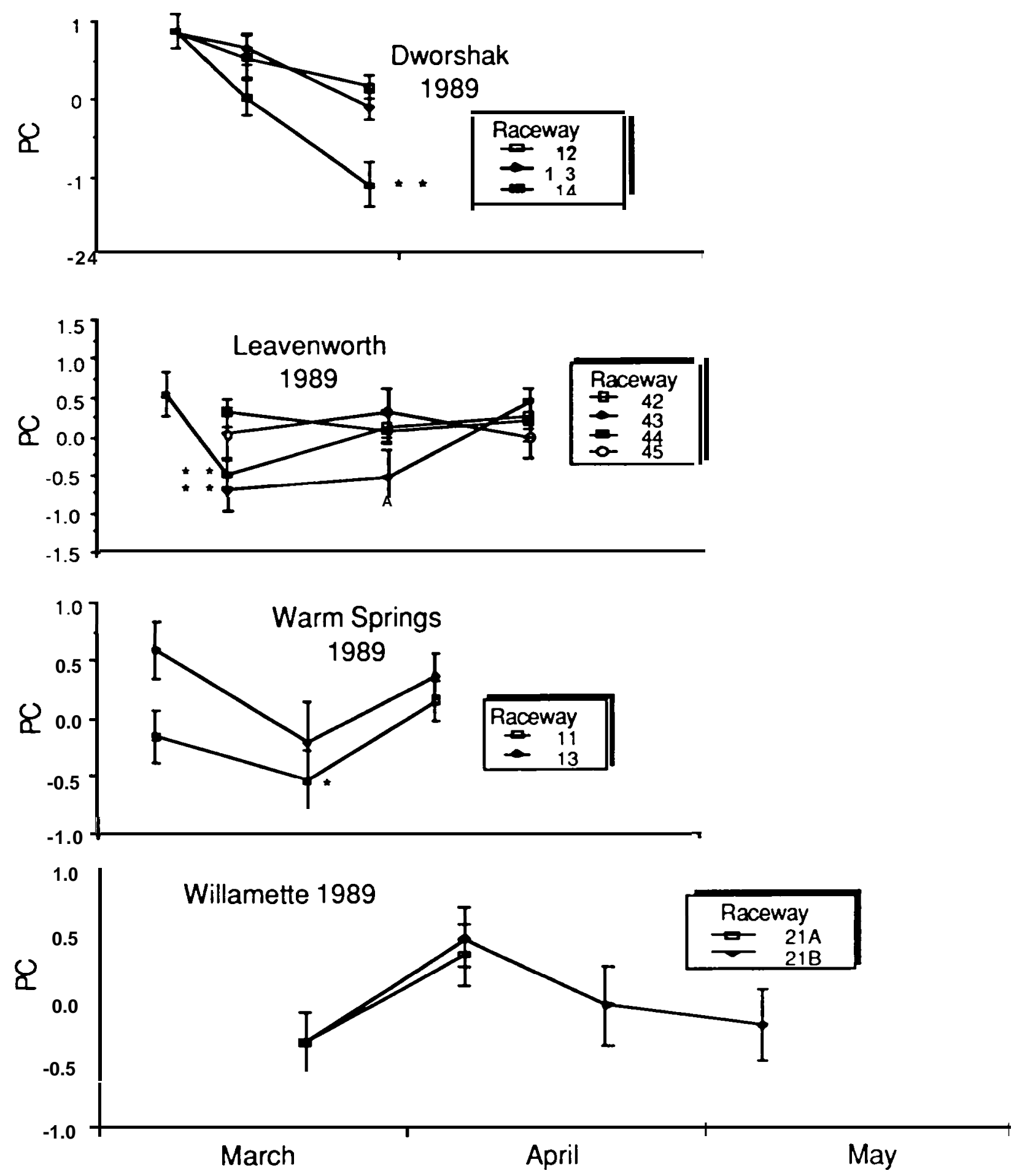

Figure 17.-- Morphometrics of body shape using principal component (PC) analysis at the indicated hatcheries. Symbols indicate means; brackets indicate \pm one standard error. Asterisks indicate values significantly less than zero $\left(^{*}=\mathrm{P}<0.05 ;{ }^{*}=\mathrm{P}<0.01\right.$ : t-test). 


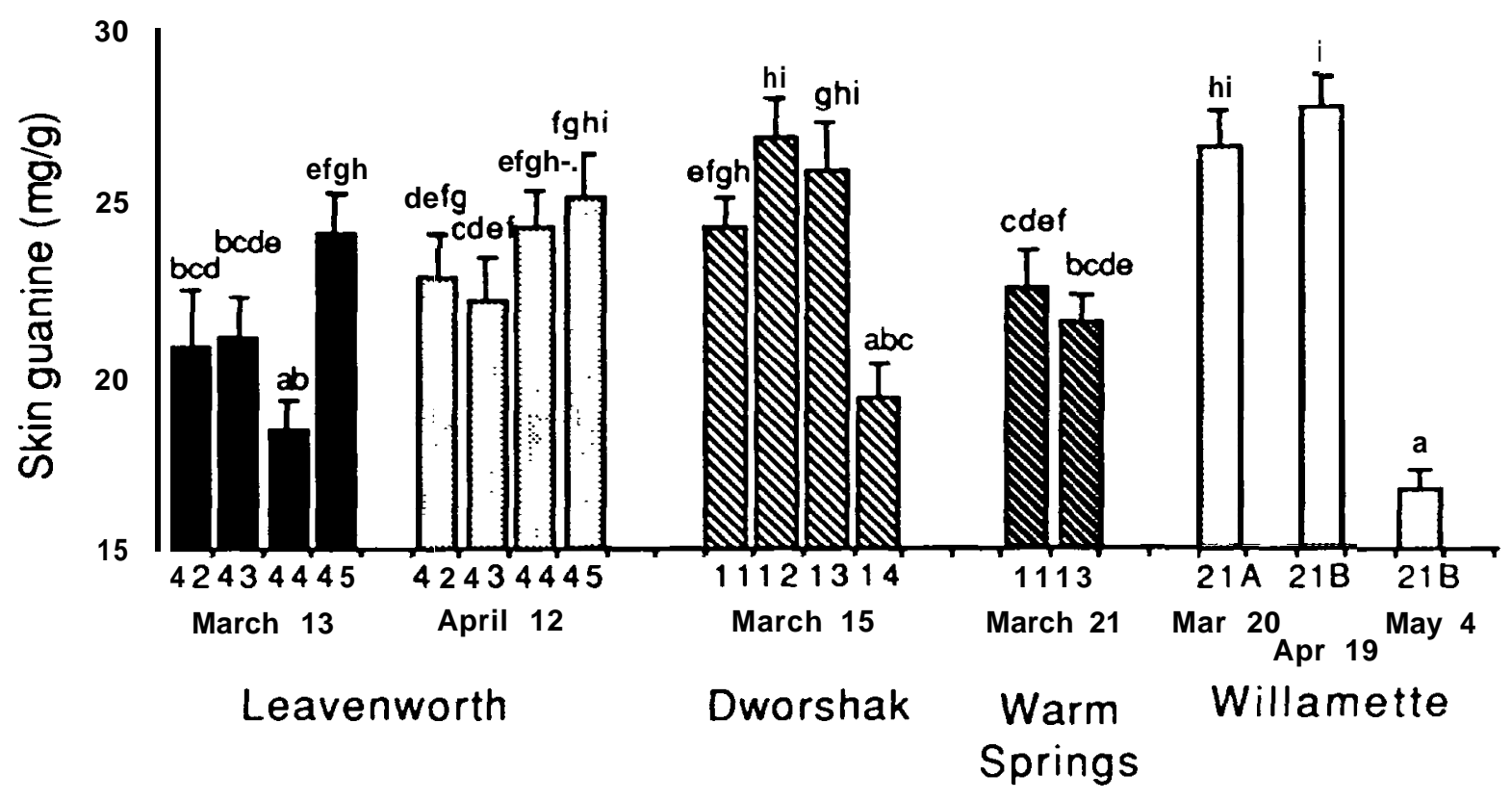

Figure 18.--Skin guanine concentrations in fish sampled at the indicated hatcheries. Vertical bars indicate means; brackets indicate + one standard error. The numbers below the bars indicate raceway number and date of sampling. Letters above bars indicate significant differences ( $\mathrm{P}<0.05$; ANOVA, Fisher PLSD). Bars with a common letter are not significantly different. 
that Willamette fish showed the highest and Leavenworth fish showed the lowest degree of smolting. The decrease in mean skin guanine concentration from 19 April to 4 May in fish at Willamette Hatchery is an unexpected finding. The fish at Willamette Hatchery on 4 May had not shown any visible reduction in silvery appearance compared to the fish at earlier sampling dates. The relationship between skin guanine content, as measured, and the silvery appearance of the skin is not well-established. Differences in the amount of nonpigmented portions of the dermis, the amount of skin adhering to the muscle, loss of scales, or the amount of adhering muscle tissue in the skin samples, may interfere with accurate measurement of guanine concentration in the pigmented layers of the skin.

Salt and Water Balance in Fresh Water

Muscle water content -- The concentration of water in dorsal skeletal muscle tissue was determined shortly before release of fish from the hatcheries (also 1 month before release at Leavenworth and Willamette Hatcheries). The mean tissue water concentrations were similar at all dates for the fish at Leavenworth, Dworshak, and Warm Springs Hatcheries (Fig. 19). The lowest mean tissue water was observed in Willamette fish in raceway $21 \mathrm{~A}$ during March. Subsequent samples from fish in raceway 21B at Willamette Hatchery showed a significant increase in muscle water.

Plasma ion and protein concentrations - - The concentrations of blood plasma sodium, potassium, chloride, and total protein were determined shortly before release from the hatcheries (also 1 month before release at Leavenworth and Willarnette Hatcheries). These parameters are indicators of general physiological state with regard to salt- and waterbalance of the fish. There were no striking differences in the plasma concentrations of ions or protein between hatcheries (Figs. $20-23$ ), although there were some statistically different values between groups. All mean values for ion and protein concentrations were within the normal ranges for healthy fish (Wedemeyer and Yasutake 1977). For plasma sodium, the lowest values were in fish at Willamette Hatchery, particularly in May (Fig. 20). The highest plasma sodium was in fish in raceway 44 at Leavenworth Hatchery on 29 March. Plasma potassium levels were uniformly low in Leavenworth fish sampled in March (Fig. 21). For plasma chlorides, most of the highest values were in fish at Leavenworth (with the exception of raceway 45 on 12 April). Plasma protein levels tended to be lowest in fish at Leavenworth Hatchery, whereas consistently higher levels were observed in fish at Warm Springs and Willamette Hatcheries. 


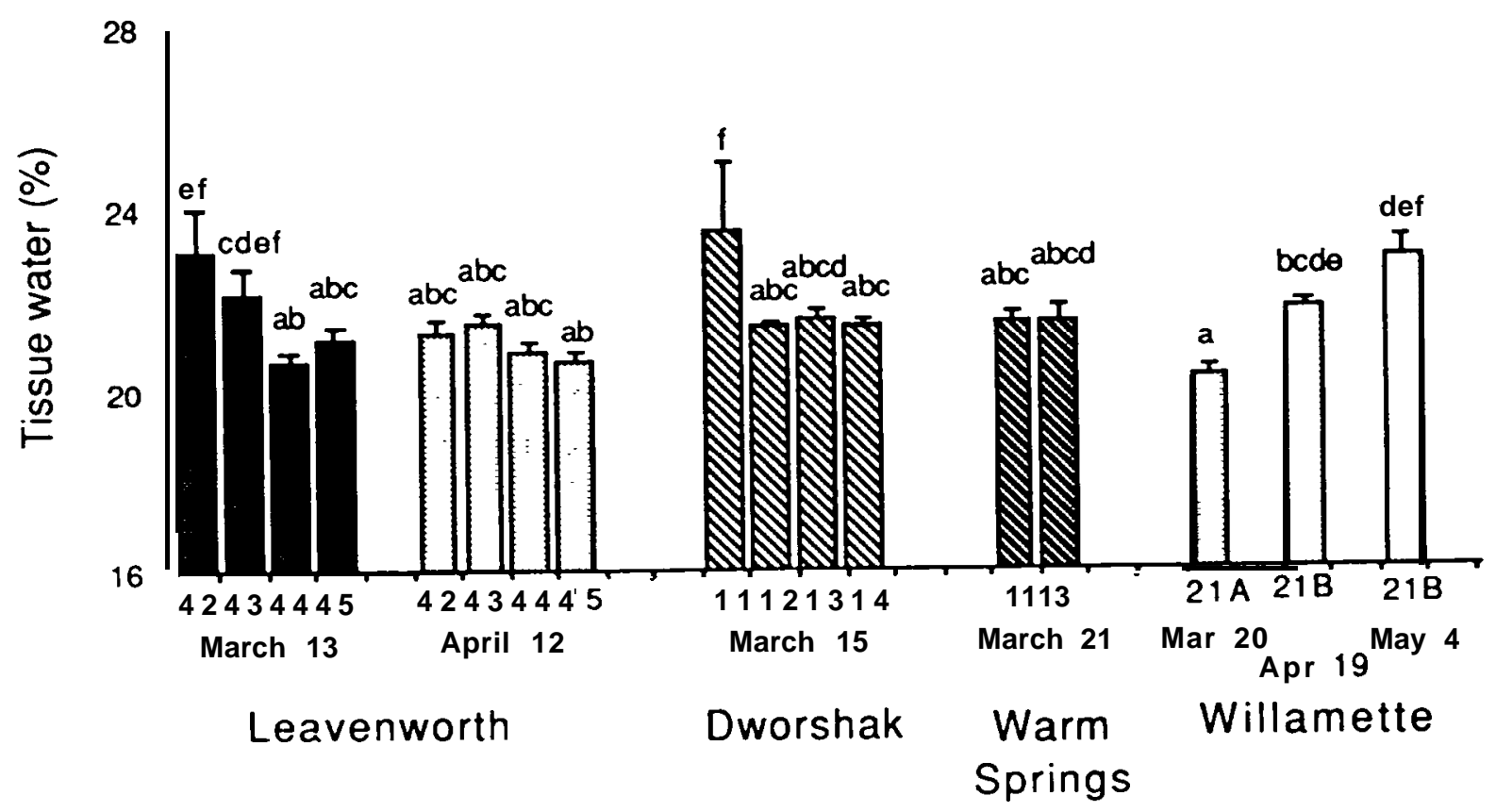

Figure 19.--Tissue water content (\%) of fish at the indicated hatcheries. Vertical bars indicate means; brackets indicate + one standard error. The numbers below the bars indicate raceway number and date of sampling. Letters above bars indicate significant differences ( $\mathrm{P}<0.05$; ANOVA, Fisher PLSD). Bars with a common letter are not significantly different. 


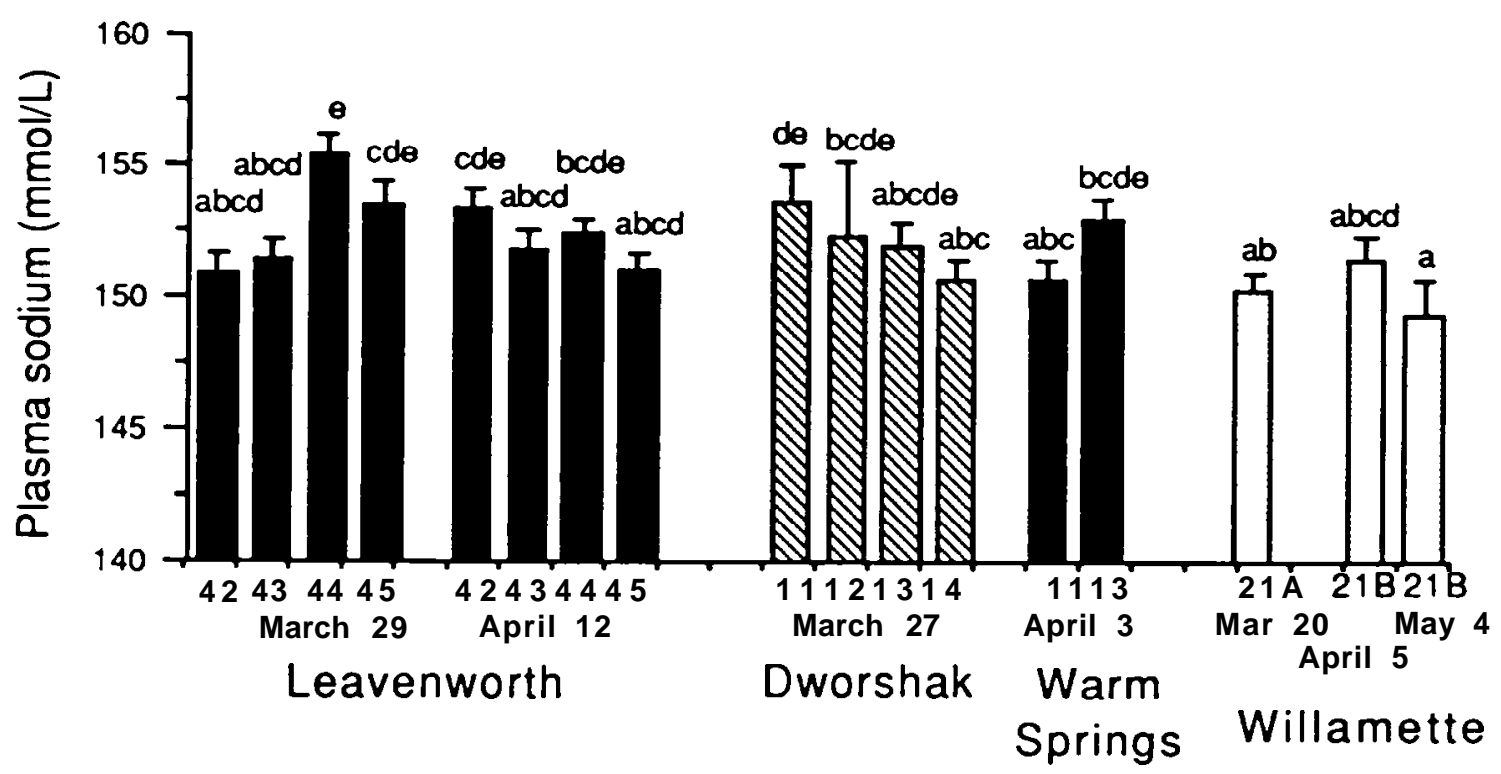

Figure 'O.--Plasma sodium concentration of fish at the indicated hatcheries. Vertical bars indicate means; brackets indicate + one standard error. The numbers below the bars indicate raceway number and date of sampling. Letters above bars indicate significant differences ( $\mathrm{P}<0.05$; ANOVA, Fisher PLSD). Bars with a common letter are not significantly different. 


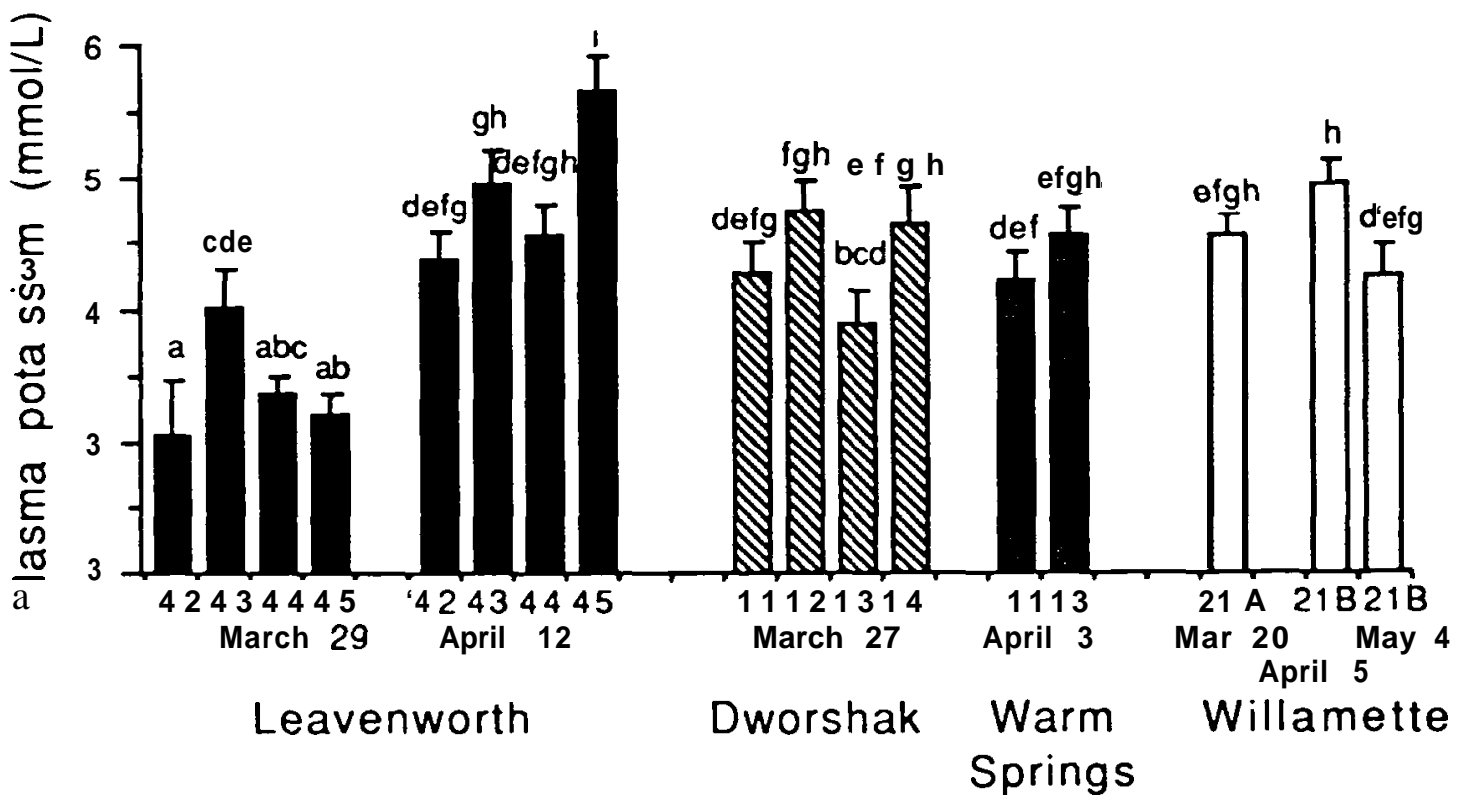

Figure 21 .--Plasma potassium concentration of fish at the indicated hatcheries. Vertical bars indicate means; brackets indicate + one standard error. The numbers below the bars indicate raceway number and date of sampling. Letters above bars indicate significant differences (P c 0.05; ANOVA, Fisher PLSD). Bars with a common letter are not significantly different. 


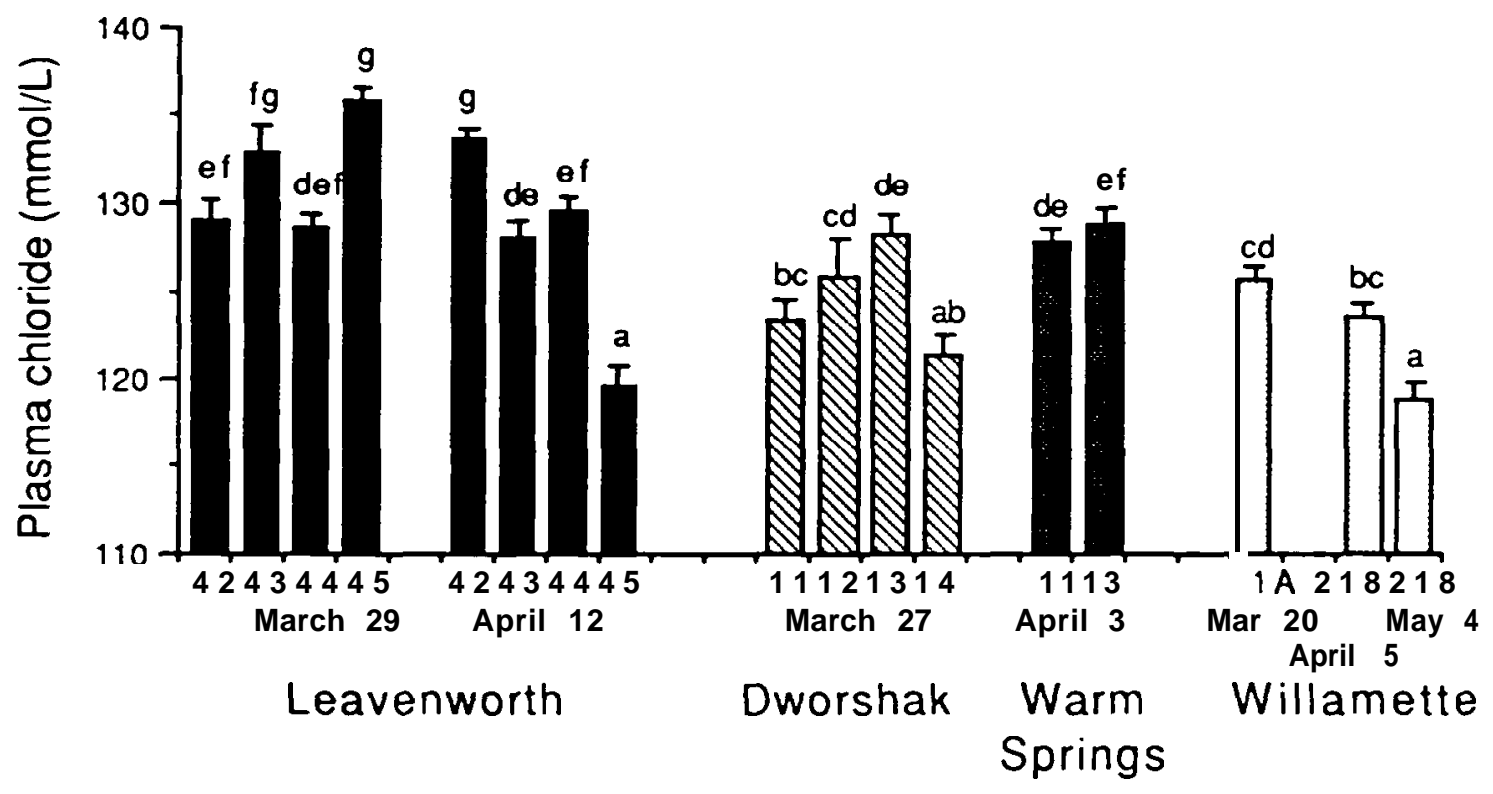

Figure 22.--Plasma chloride concentration of fish at the indicated hatcheries. Vertical bars indicate means; brackets indicate + one standard error. The numbers below the bars indicate raceway number and date of sampling. Letters above bars indicate significant differences ( $\mathrm{P}<0.05$; ANOVA, Fisher PLSD). Bars with a common letter are not significantly different. 


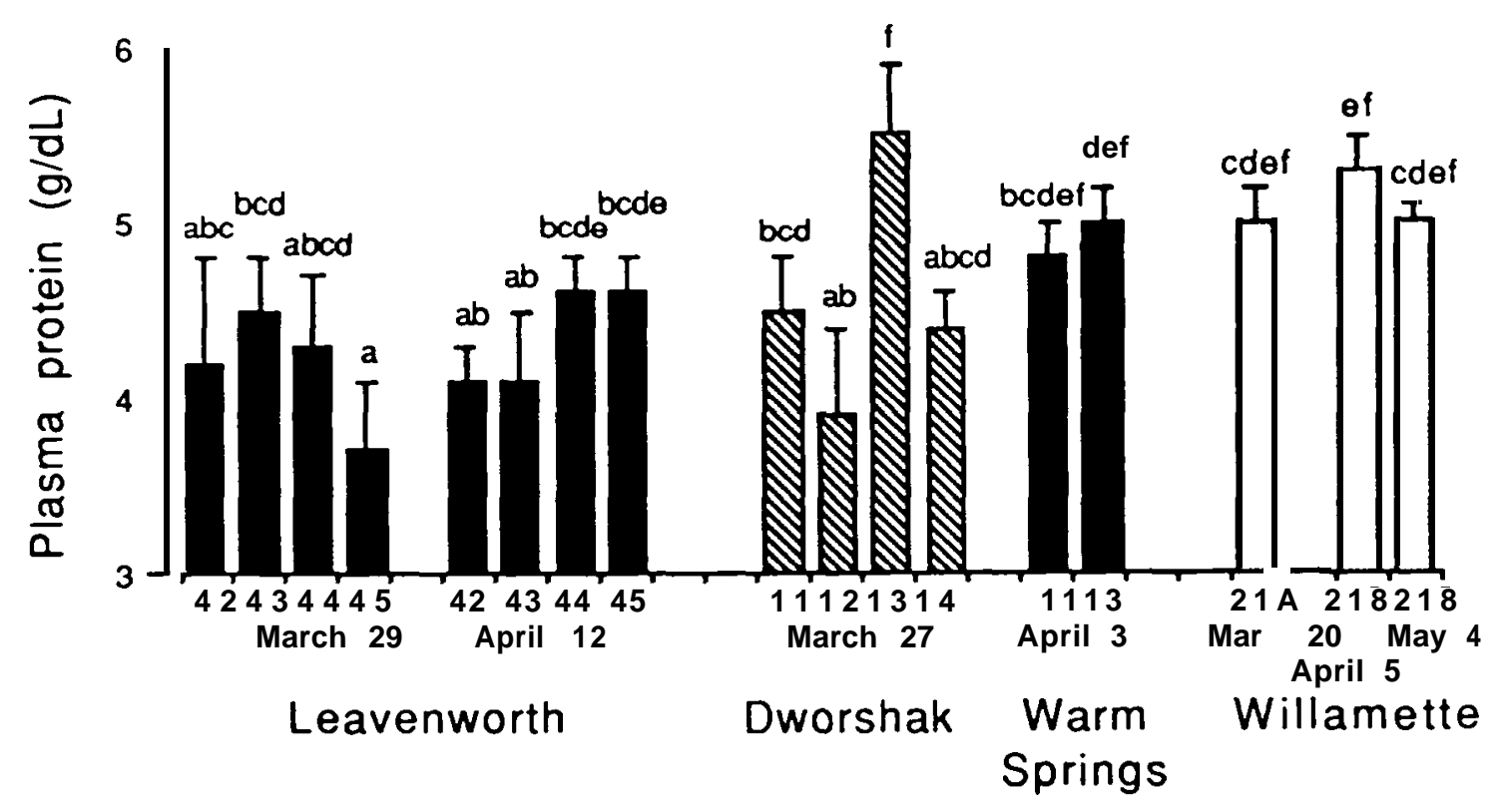

Figure 23.--Plasma protein concentration of fish at the indicated hatcheries. Vertical bars indicate means; brackets indicate + one standard error. The numbers below the bars indicate raceway number and date of sampling. Letters above bars indicate significant differences ( $\mathrm{P}<0.05$; ANOVA, Fisher PLSD). Bars with a common letter are not significantly different. 
Blood Cells

The total number and proportion of red blood cells, white blood cells, and white cell types are indicators of general health of fish. Hematocrits were determined every 2 weeks. The number of white cells and differential white cell counts were determined for fish sampled shortly before release, and also 1 month before release at Leavenworth and Willamette Hatcheries.

Hematocrit - - Hematocrit values for blood samples from fish at the various hatcheries ranged from 25 to $40 \%$ (Fig. 24). At all times in fish at all hatcheries, hematocrit values were within normal ranges for healthy fish (Wedemeyer and Yasutake 1977). At Dworshak Hatchery, hematocrits declined from initial values in fish in raceways 12 and 14, but remained relatively constant in raceways 11 and 13. For fish at Leavenworth, hematocrits declined from initial high values in three of the four raceways examined. At the end of sampling at Leavenworth, hematocrits had returned to near initial values in fish in raceways 43 and 45, but not in raceways 42 and 44. At Warm Springs, hematocrits were initially high in the fish held at normal density (raceway 13) compared to one-half normal density (raceway 11). For fish in both raceways at Warm Springs, hematocrits declined to significantly lower values in late March and early April samples. At Willamette, there was no significant change in hematocrit values over time for fish in raceway $21 \mathrm{~A}$. For fish in raceway $21 \mathrm{~B}$, there was a significant increase in hematocrits from early April to shortly before release.

Statistical analysis of all hematocrit data showed that most of the fish at Dworshak Hatchery had significantly lower hematocrits compared to fish at the other three hatcheries. The reason for this difference is not clear. Low water temperature may increase hematocrits in salmonids (Dewilde and Houston 1967); however, the fish at Dworshak were at similar or higher temperature $\left(5^{\circ}-6^{\circ} \mathrm{C}\right)$ compared to those at Leavenworth Hatchery ( $2^{\mathbf{0}}-6.50 \mathrm{C}$ ), for example. A relatively high incidence (up to $40 \%$ ) of bacterial kidney disease had been diagnosed for Dworshak fish (Warren 1989). Kidney damage from this disease may have reduced hematocrit. 

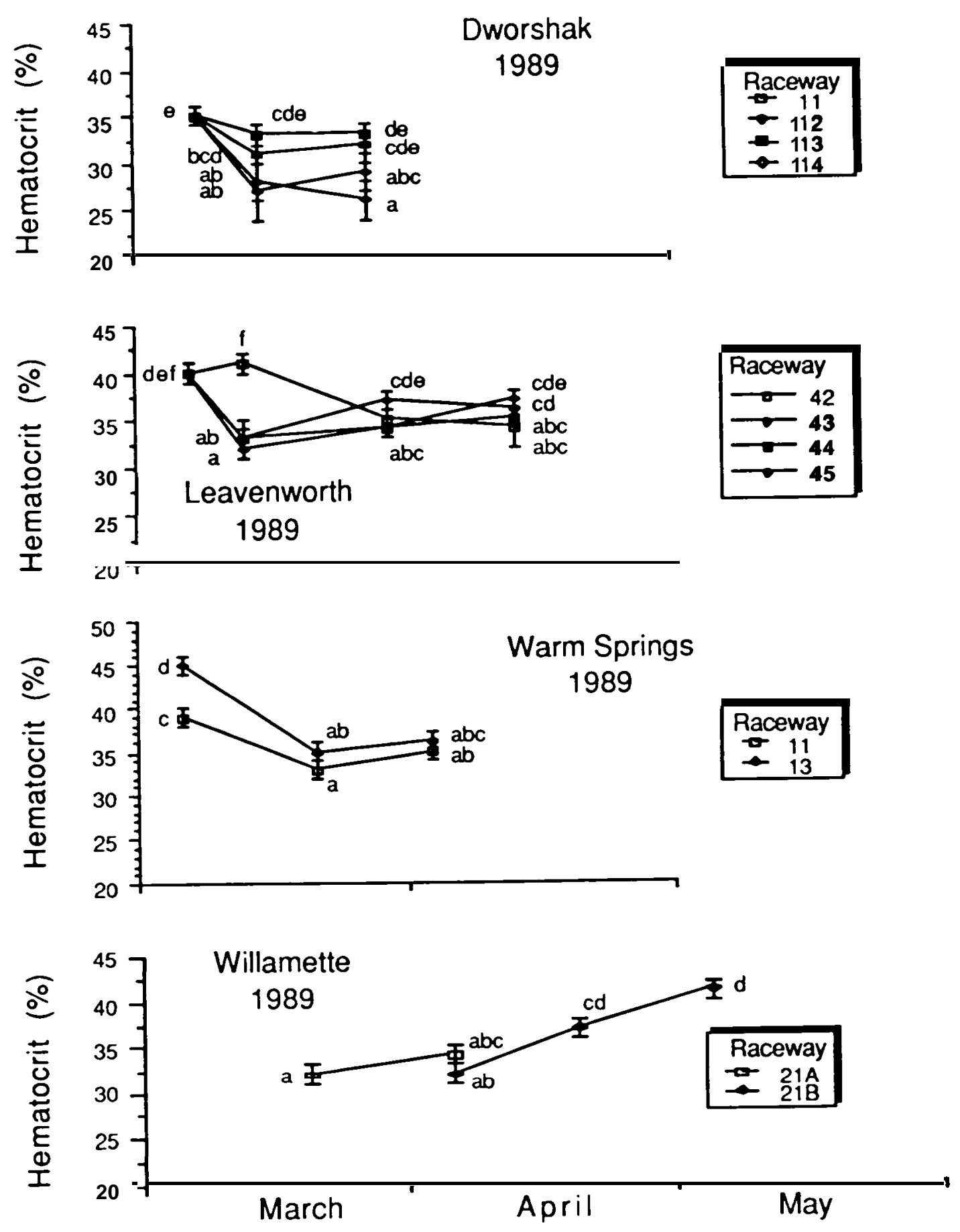

Figure 24.--Hematocrits of fish at the indicated hatcheries. Symbols indicate means; brackets indicate \pm one standard error. Letters near symbols indicate significant differences within a hatchery $(\mathrm{P}<0.05$; ANOVA, Fisher PLSD). Bars with a common letter are not significantly different. 
White cell count - - The mean white cell counts of fish from all hatcheries were between 0.6 and $0.9 \%$ of total blood cells (Fig. 25), which is within the normal range observed for healthy juvenile salmon (Wedemeyer and Yasutake 1977). The only statistically significant differences in white cell counts among all groups of fish examined were in the fish at Dworshak Hatchery.

Lymphocytes - - The proportion of lymphocytes in fish at all hatcheries was between 87 and $97 \%$ of the total white cell count (Fig. 26). This range of lymphocyte percentage is close to the normal range (89-98\%) reported for healthy rainbow trout (Wedemeyer and Yasutake 1977). The highest lymphocyte proportion was found in fish in raceway $21 \mathrm{~B}$ at Willamette Hatchery. The lowest proportion of lymphocytes was observed in fish in raceway 42 on 29 March at Leavenworth Hatchery.

Neutrophils - - The mean proportions of neutrophils in fish at all hatcheries were between 4 and 12\% of total white blood cells (Fig. 27). The reported normal range for neuuophils in healthy juvenile rainbow trout is 1 to $9 \%$ (Wedemeyer and Yasutake 1977). The only groups outside the normal range were fish in raceway 42 at Leavenworth on 29 March and in raceway 14 at Dworshak on 27 March. The lowest neutrophil counts were for fish in raceway 21B at Willamette Hatchery.

Monocytes - - hlonocytes were observed only occasionally in blood samples from all fish, and the incidence of monocytes was not strikingly higher in any group.

Immune Competence

The capacity for immune response by cultured anterior kidney lymphocytes was examined for fish at Dworshak, Warm Springs, and Willamette Hatcheries (Table 2). Fish at Dworshak Hatchery showed no immune response on the date tested. The greatest immune response, as determined by the number of plaques formed, was from fish at Willamette Hatchery on 5 and 19 April. There was no correlation between either the number or types of white blood cells and the capacity for immune response. 


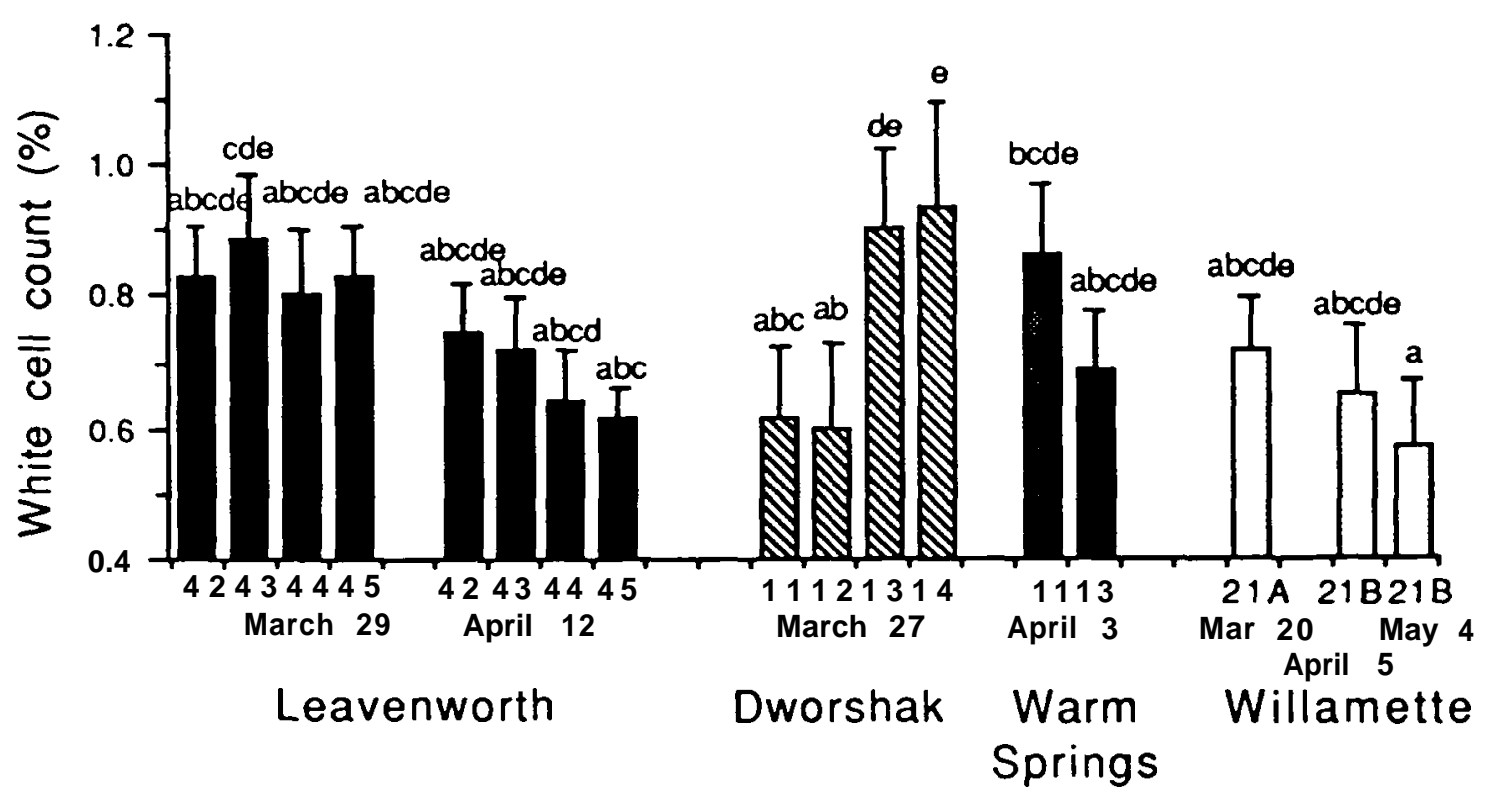

Figure 25.--White cell count ( $\%$ of total blood cells) of fish at the indicated hatcheries. Vertical bars indicate means; brackets indicate + one standard error. The numbers below the bars indicate raceway number and date of sampling. Letters above bars indicate significant differences $(\mathrm{P}<0.05$; ANOVA, Fisher PLSD). Bars with a common letter are not significantly different. 


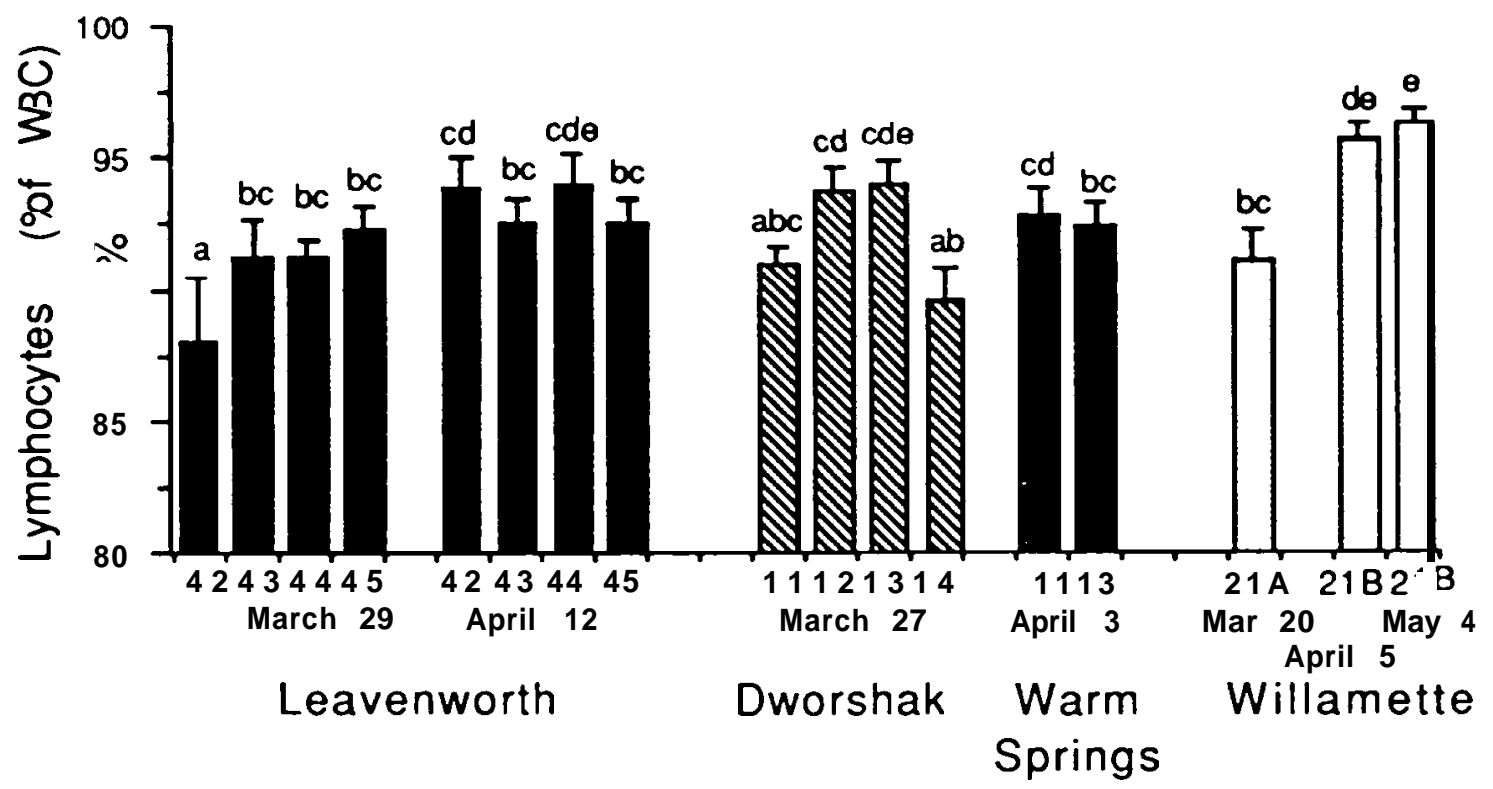

Figure 26.--Blood concentration of lymphocytes (\% of white blood cells) of fish at the indicated hatcheries. Vertical bars indicate means; brackets indicate + one standard error. The numbers below the bars indicate raceway number and date of sampling. Letters above bars indicate significant differences $(\mathrm{P}<0.05$; ANOVA, Fisher PLSD). Bars with a common letter are not significantly different. 


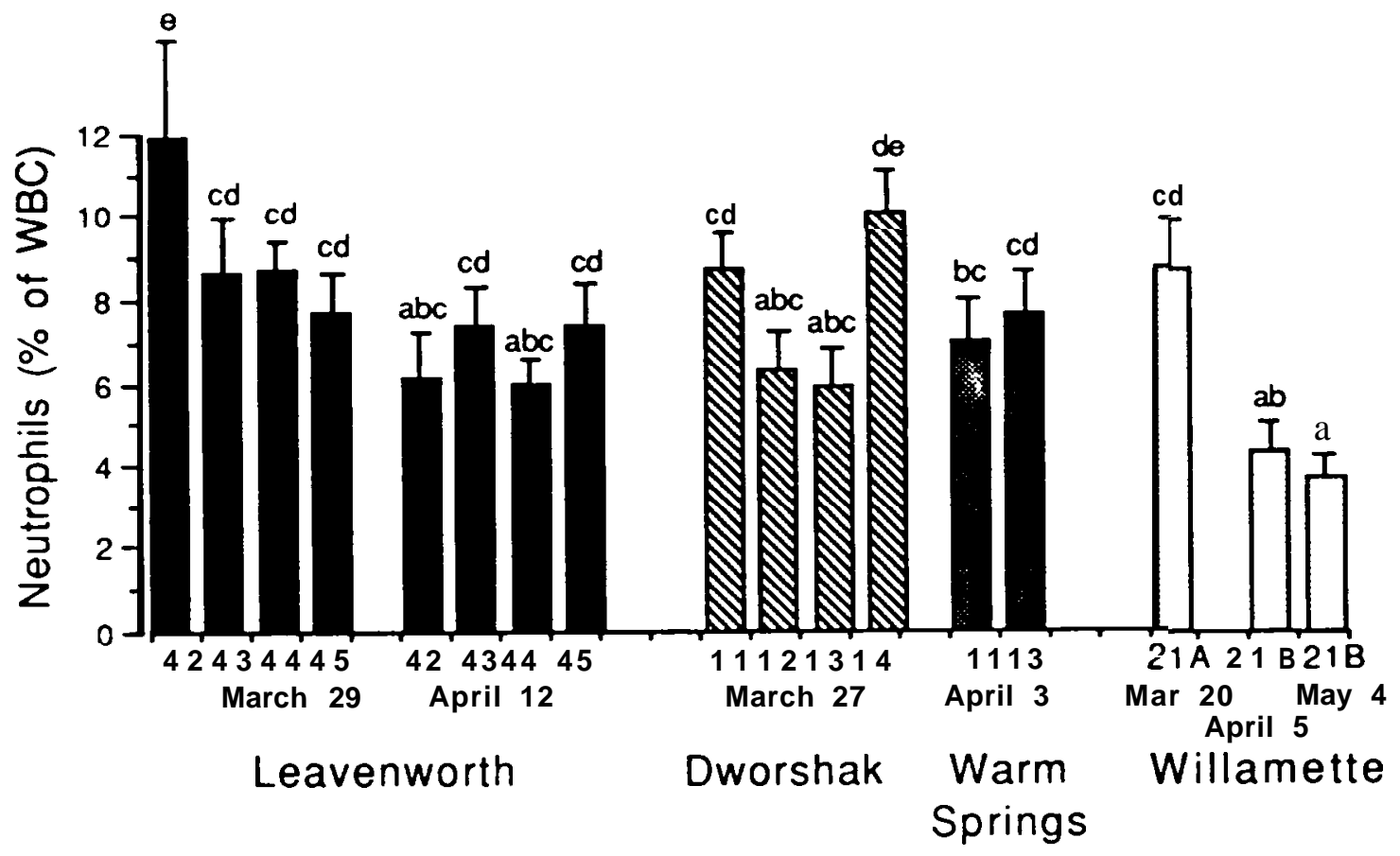

Figure 27.--Blood concentration of neutrophils ( $\%$ of white blood cells) of fish at the indicated hatcheries. Vertical bars indicate means; brackets indicate + one standard error. The numbers below the bars indicate raceway number and date of sampling. Letters above bars indicate significant differences ( $<<0.05$; AKOVA, Fisher PLSD). Bars with a common letter are not significantly different. 
Table 2.-- Immune response of cultured anterior kidney lymphocytes from fish at Dworshak, Warm Springs, and Willamette Hatcheries sampled on the indicated dates. Formation of a plaque is indication of an antibody-producing cell.

\begin{tabular}{lccc}
\hline Hatchery & Date & Raceway & Plaques/culture* \\
\hline Dworshak & March 28 & 13 & $0^{\mathbf{a}}$ \\
Dworshak & March 28 & 14 & $\mathbf{0}^{\mathbf{a}}$ \\
Warm Springs & April 3 & 11 & $98 \pm 33^{\mathbf{b}}$ \\
Warm Springs & April 3 & 13 & $196 \pm 85^{\mathbf{b c}}$ \\
Willamette & April 5 & $21 \mathrm{~A}$ & $270 \pm 52^{\mathrm{c}}$ \\
Willamette & April 5 & $21 \mathrm{~B}$ & $188 \pm 55^{\mathbf{b c}}$ \\
Willamette & April 19 & $21 \mathrm{~B}$ & $298 \pm 56^{\mathbf{c}}$ \\
Willamette & May 4 & $21 \mathrm{~B}$ & $183 \pm 39^{\mathbf{b c}}$ \\
\hline
\end{tabular}

* The number indicates the mean of 20 cultures \pm one standard error. The superscript letters indicate statistical differences (ANOVA, Fisher PLSD, P < 0.05). Numbers that share a common superscript letter are not significantly different. 


\section{Relationship Between Replicate Raceways}

Replicate raceways of production fish (four raceways) were sampled at Dworshak and Leavenworth Hatcheries to evaluate the degree of raceway-to-raceway variation in the measured parameters. Due to the time required for sampling, the four raceways were sampled over 2 days. At Dworshak, one set of samples was taken on 15 and 16 March; a second set was taken on 27 and 28 March. At Leavenworth, one set of samples was taken on 13 and 14 March, one set on 29 and 30 March, and a third set on 12 and 13 April. Each set of data was analyzed for significant differences using ANOVA and Fisher PLSD test at $P<0.05$. Neither body weight nor fork length of the fish sampled from the four raceways in each set was significantly different, indicating that there was no size-dependent bias in any set of samples (Tables 3 and 4). Of the 25 parameters evaluated, body weight, body length, saltwater $\mathrm{Na}$ and $\mathrm{K}$, gill ATPase activity of fish in fresh water, PC values, and white cell count showed no variation among raceways. Of the 379 measurements, there were 63 significant differences. Over half (37) of the observed differences were in plasma concentrations of T4, T3, cortisol, potassium, glucose, liver glycogen, and liver triglycerides, all of which have been shown to either vary diurnally, or change in relation to time after feeding (Eales et al. 1981; Laidley and Leatherland 1988). Thus, differences in time of day or in time after feeding when samples were taken may account for the observed variation. For example, comparison of T4 levels in fish sampled either in the morning or in the afternoon show little variation between raceways (Fig. 8). Therefore, for parameters that show circadian rhythm or a relationship to feeding, the time of day and time since last feeding should be standardized in the sampling procedure. For the remaining parameters, there were 26 differences out of 163 measurements. The 26 differences appeared to be randomly distributed among the parameters measured. Random differences may be due to the fact that measures of health may show wide variation because of major differences in disease in different raceways.

In general the differences observed were minor, usually within 10 to $20 \%$ of the average value for all groups. These differences were small in comparison to the seasonal changes anticipated for some of the parameters. For example, the differences in plasma T4 levels between replicate raceways was 2 to $4 \mathrm{ng} / \mathrm{ml}$. The anticipated increase in plasma T4 associated with the parr-smolt transformation is at least a 10 to $20 \mathrm{ng} / \mathrm{ml}$ increase over the baseline value (Dickhoff et al. 1978, 1982b). Thus, the T4 elevation during smolting is much greater than either our observed variation between raceways or the circadian 
Table 3.--Variation in measurements of fish from replicate raceways at Leavenworth Hatchery. Each set of four raceways was tested for significant differences $(\mathrm{P}<0.05$, ANOVA, Fisher PLSD). Dashes indicate no significant differences among raceways. Significant differences are indicated by letters. Raceways with common letters are not significantly different within the set of four raceways.

\begin{tabular}{|c|c|c|c|c|c|c|c|c|c|c|c|c|}
\hline \multirow[t]{2}{*}{ Date } & \multicolumn{4}{|c|}{$\begin{array}{c}\text { March } 13-14 \\
\text { Raceway }\end{array}$} & \multicolumn{4}{|c|}{$\begin{array}{c}\text { March } 29-30 \\
\text { Raceway }\end{array}$} & \multicolumn{4}{|c|}{$\begin{array}{c}\text { April } 12=13 \\
\text { Raceway }\end{array}$} \\
\hline & 42 & 43 & 44 & 45 & 42 & 43 & 44 & 45 & 42 & 43 & 44 & 45 \\
\hline \multicolumn{13}{|l|}{ Parameter } \\
\hline Weight & - & - & - & - & - & - & - & - & - & - & - & - \\
\hline Length & - & - & - & - & - & - & - & . & - & - & - & - \\
\hline Saltwater $\mathrm{Na}$ & & & & & - & - & - & - & - & - & - & - \\
\hline Saltwater K & & & & & - & - & - & - & - & - & - & - \\
\hline SW ATPase & & & & & $\mathbf{a}$ & a & $\mathbf{a}$ & b & - & - & - & - \\
\hline FW ATPase & & & & & - & - & - & - & - & - & - & - \\
\hline T4 & $a b$ & $\mathrm{a}$ & $\mathrm{b}$ & b & $\mathbf{a}$ & $a b$ & b & b & $\mathbf{a}$ & $\mathbf{a}$ & b & b \\
\hline T3 & & $\mathrm{a}$ & $\mathrm{a}$ & b & & $\mathbf{a}$ & $\mathbf{a}$ & b & & a & b & b \\
\hline Cortisol & - & - & & - & $\mathbf{a}$ & b & b & b & a & a & b & c \\
\hline Stress Cortisol & $\mathrm{a}$ & $\mathrm{a}$ & $\mathrm{a}$ & b & $\mathbf{a}$ & b & $\mathbf{a}$ & $\mathbf{a}$ & $\mathbf{a}$ & b & $\mathrm{b}$ & $\mathrm{b}$ \\
\hline Stress Glucose & $\mathrm{a}$ & $\mathrm{a}$ & $\mathrm{a}$ & b & $\mathbf{a b}$ & c & b & $\mathbf{a}$ & $\mathbf{a}$ & $\mathbf{a b}$ & $\mathrm{b}$ & $a b$ \\
\hline Normal Glucose & & - & - & - & & $\mathbf{a}$ & $\mathbf{a}$ & b & & $\mathbf{a}$ & $\mathbf{a}$ & $\mathrm{b}$ \\
\hline Liver Glycogen & $a b$ & $\mathrm{~b}$ & $a b$ & $\mathbf{a}$ & & & & & - & - & - & - \\
\hline Liver Triglyc. & $\mathrm{b}$ & $\mathrm{a}$ & $\mathrm{b}$ & c & & & & & $\mathbf{a} \mathbf{b}$ & $a b$ & b & $\mathbf{a}$ \\
\hline Morphometric PC & - & - & - & - & - & - & - & - & - & - & - & - \\
\hline Skin Guanine & $a b$ & $a b$ & $\mathrm{a}$ & b & & & & & - & - & - & - \\
\hline Muscle Water & $\mathrm{a}$ & $a b$ & c & $b c$ & & & & & - & - & - & - \\
\hline Plasma Sodium & a & $\mathrm{a}$ & b & $\mathbf{a b}$ & & & & & - & - & - & - \\
\hline Plasma Potassium & $\mathrm{a}$ & $\mathrm{b}$ & $a b$ & $\mathbf{a}$ & & & & & $\mathbf{a}$ & $\mathbf{a}$ & $\mathbf{a}$ & b \\
\hline Plasma Chloride & a & $\mathrm{a}$ & $\mathrm{a}$ & b & & & & & $\mathbf{a}$ & b & b & c \\
\hline Plasma Protein & $a b$ & b & $a b$ & $\mathbf{a}$ & & & & & - & - & - & - \\
\hline Hematocrit & $\mathrm{a}$ & $\mathrm{b}$ & $\mathrm{b}$ & b & - & - & - & - & - & - & - & - \\
\hline White Cell Count & - & - & - & - & - & - & - & - & - & - & - & - \\
\hline Lymphocytes & $\mathrm{a}$ & $\mathrm{b}$ & $\mathrm{b}$ & b & & & & & - & - & - & - \\
\hline Neutrophiis & $\mathrm{a}$ & b & $\mathrm{b}$ & b & & & & & - & - & - & - \\
\hline
\end{tabular}


Table 4.--Variation in measurements of fish from replicate raceways at Dworshak Hatchery. Each set of four raceways was tested for significant differences $(\mathrm{P}<0.05$, ANOVA, Fisher PLSD). Dashes indicate no significant differences among raceways. Significant differences are indicated by letters. Raceways with common letters are not significantly different within the set of four raceways.

\begin{tabular}{|c|c|c|c|c|c|c|c|c|}
\hline \multirow{2}{*}{$\begin{array}{l}\text { Date } \\
\text { Parameter }\end{array}$} & \multicolumn{4}{|c|}{$\begin{array}{c}\text { March } 15-16 \\
\text { Raceway }\end{array}$} & \multicolumn{4}{|c|}{$\begin{array}{c}\text { March } 27-28 \\
\text { Raceway }\end{array}$} \\
\hline & 11 & 12 & 13 & 14 & 11 & 12 & 13 & 14 \\
\hline Weight & - & & - & & - & - & - & - \\
\hline Length & - & - & - & - & - & & - & - \\
\hline Saltwater $\mathrm{Na}$ & & & & & - & - & - & - \\
\hline Saltwater K & & & & & $\mathrm{a}$ & a & $\mathbf{a}$ & $\mathrm{b}$ \\
\hline SW ATPase & & & & & $\mathrm{b}$ & a & b & $a b$ \\
\hline FW ATPase & & & & & - & & - & \\
\hline $\mathrm{T} 4$ & $\mathrm{a}$ & $\mathrm{a}$ & $\mathrm{b}$ & $\mathrm{a}$ & - & - & - & - \\
\hline $\mathrm{T} 3$ & & $\mathrm{a}$ & $\mathrm{b}$ & $\mathrm{a}$ & & a & $\mathrm{b}$ & $\mathrm{b}$ \\
\hline Cortisol & - & - & - & - & $\mathrm{a}$ & $\mathrm{b}$ & $a b$ & $c$ \\
\hline Stress Cortisol & $\mathrm{a}$ & $\mathrm{b}$ & $\mathrm{a}$ & $\mathrm{b}$ & $\mathrm{a}$ & $\mathrm{a}$ & $\mathrm{a}$ & b \\
\hline Stress Glucose & $\mathrm{a}$ & $a b$ & $a b$ & $\mathrm{~b}$ & $\mathrm{a}$ & $\mathrm{b}$ & a & $\mathrm{a}$ \\
\hline Normal Glucose & a & $\mathrm{a}$ & $\mathrm{b}$ & $\mathrm{b}$ & $\mathrm{a}$ & $\mathrm{a}$ & $\mathrm{b}$ & $\mathrm{a}$ \\
\hline Liver Glycogen & & & & & - & & - & - \\
\hline Liver Triglyc. & & & & & $\mathrm{b}$ & $a b$ & $\mathrm{~b}$ & $\mathrm{a}$ \\
\hline Morphometric PC & - & - & - & - & & $\mathrm{a}$ & a & $\mathrm{b}$ \\
\hline Skin Guanine & & & & & $\mathrm{a}$ & a & $\mathrm{a}$ & $\mathrm{b}$ \\
\hline Muscle Water & & & & & $\mathrm{a}$ & $\mathrm{b}$ & $\mathrm{b}$ & $\mathrm{b}$ \\
\hline Plasma Sodium & & & & & $\mathrm{a}$ & $a b$ & $a b$ & $\mathrm{~b}$ \\
\hline Plasma Potassium & & & & & $a b$ & $\mathrm{~b}$ & $\mathrm{~b}$ & $a b$ \\
\hline Plasma Chloride & & & & & $a b$ & $\mathrm{bc}$ & c & $\mathrm{a}$ \\
\hline Plasma Protein & & & & & $\mathrm{a}$ & $\mathrm{a}$ & b & $\mathrm{a}$ \\
\hline Hcmatocrit & $a b$ & $\mathrm{a}$ & $\mathrm{b}$ & $\mathrm{a}$ & $\mathrm{bc}$ & $\mathrm{a}$ & c & $a b$ \\
\hline White Cell Count & & & & & $\mathrm{a}$ & $\mathrm{a}$ & b & $\mathrm{b}$ \\
\hline Lymphocytes & & & & & $a b$ & $\mathrm{~b}$ & $\mathrm{~b}$ & $\mathrm{a}$ \\
\hline Neutrophils & & & & & $a b$ & $\mathrm{a}$ & $\mathrm{a}$ & $\mathrm{b}$ \\
\hline
\end{tabular}


variation. Some of the observed differences may be partly due to lack of precision in measurement, or our inability to obtain a random sample of the population of production fish. Furthermore, we suspect that all raceways within a hatchery are not equivalent. Some of the differences may be spurious due to the large number of measurements analyzed at a significance level of $\mathrm{P}<0.05$. Regardless of its basis, variation will be accounted for in the final analysis of the reliability of measured parameters as indices for smolt quality. It is interesting to note that gill ATPase of fish in fresh water, and also saltwater challenge sodium levels, showed no significant variation; both of these measures are well-established indicators of smolt quality based on laboratory studies (Hoar 1988).

We concluded from the analysis of replicate raceways that the magnitude of raceway-toraceway variation is not large enough to warrant multiple raceway sampling. Future sampling will rely on a single raceway per treatment group per hatchery.

\section{Warm Springs Density Study}

At Warm Springs Hatchery, raceway 11 had half the normal density of production fish, whereas raceway 13 was loaded at the normal density. Comparison of these two groups revealed differences in a few of the parameters measured. The size of the fish sampled was equivalent. At the last sampling date (3 April), the fish from raceway 11 were $139 \pm 4$ $\mathrm{mm}$ long (average \pm standard error) and weighed $30.7 \pm 2.6 \mathrm{~g}$. On 3 April, fish sampled from raceway 13 were $141 \pm 4 \mathrm{~mm}$ long and weighed $31.3 \pm 2.3 \mathrm{~g}$. The unstressed plasma cortisol level was significantly higher in fish from raceway 11 compared to 13 in early March (Fig. 1 1), but in April, plasma cortisol was higher in fish from raceway 13. Stress-induced cortisol elevation was significantly higher in fish in raceway 13 in early March, but not in subsequent tests (Fig. 12). The unstressed levels of plasma glucose were higher in fish in raceway 13 during the late March and April sampling dates (Fig. 14). The only other statistically significant difference observed between fish in raceways 11 and 13 was the higher hematocrits in fish from raceway 13 in early March (Fig. 24). These data suggest that fish at lower density have slightly different interrenal responses to handling stress, and their seasonal cortisol production or clearance may differ. There were no differences in performance in the saltwater challenge, thyroid hormone, or insulin profiles, liver glycogen or triglyceride, morphometrics, skin guanine, muscle water, plasma ions, white blood cell counts, or immune response. In general, there is little evidence to suggest that smolt quality differed substantially in the fish at these two densities. 


\section{SUMMARY}

Although the main objective of this study is to evaluate smolt quality indicators based on adult survival, we can evaluate the degree to which the production fish at the four hatcheries conform to the expected pattern of smolting from previous studies. The expected changes are based primarily on laboratory studies of the relationship between the index measured and successful smolt performance (3- to 6- month survival and growth in seawater). Comparisons indicate that fish from Willamette Hatchery, particularly the May release group (raceway 21B), showed characteristic smolt development by the time of release (Table 5). Groups at the other hatcheries showed little or no development of smolt characteristics up to the time of release. We speculate that if the fish at Dworshak, Leavenworth, and Warm Springs Hatcheries had been held for a longer period before release, the parameters that we measured would have indicated significant development.

It might be predicted from these results that survival of adults from the production groups would be highest for the May release at Willamette. Fish released from the other hatcheries would have uniformly poorer survival compared to Willamette. The reliability of this prediction must wait until data become available from adult returns and tag recovery from the fishery. When data on adult contribution become available, these will be compared with our rankings (Table 5). Such a comparison should reveal the utility of the various smolt indices. Ultimately, a suite of measures of smolt quality will be developed; these measures could be weighted for their relative reliability for predicting adult contribution.

The production fish in this study were not released at the same time at all hatcheries. Since river flows, estuarine conditions, and nearshore ocean conditions undoubtedly vary over the time that the fish were released, and since these factors may differentially influence smolt (and adult) survival, it may not be valid to compare adult survival among hatcheries (Francis et al. 1989; Schiewe et al. 1989). Information on rates of downstream migration, estuarine residence, and early ocean survival could supply supplementary information to compare with the smolt quality data. However, such information will not be available.

Another problematic aspect of our study is the relative ranking of the hatcheries (Table 5) and hatchery location. Our rankings suggest that Willamette fish had the highest quality smolts. Willamette is located below Bonneville Dam, whereas the other hatcheries are midor upper-river hatcheries. Fish released from Willamette Hatchery do not have to negotiate passage at dams, and this factor alone may favor survival of Willamette fish relative to the other hatcheries in our study. Thus, if the adult contribution of fish released from 
Table 5.-- Relative ranking of hatchery groups with regard to expected profile of smolt indicators. Highest ranking $=4$; lowest ranking $=1$. Parameters that show no ranking, e.g., blood cell counts, had values within the normal range with no differences of major significance. It should be noted that since time-course data are available for Willamette raceway 21B only, ranking of immune competence for all hatcheries is questionable.

\begin{tabular}{|c|c|c|c|c|c|c|}
\hline \multirow{3}{*}{$\begin{array}{l}\text { Hatchery } \\
\text { Raceway: } \\
\text { Parameter }\end{array}$} & \multirow{2}{*}{$\frac{\text { Dworshak }}{\underline{11-14}}$} & \multirow{2}{*}{$\begin{array}{l}\text { Leavenworth } \\
\underline{42-45}\end{array}$} & \multicolumn{2}{|c|}{ Warm Springs } & \multicolumn{2}{|c|}{ Willametue } \\
\hline & & & 11 & 13 & $\underline{21 \mathrm{~A}}$ & $\underline{21 B}$ \\
\hline & & & & & & \\
\hline Fork Lngth & 2 & 1 & 2 & 2 & 3 & 4 \\
\hline Bod. Wt. & 2 & 1 & 2 & 2 & 3 & 4 \\
\hline Cond. Fact & 1 & 2 & 2 & 2 & 3 & 4 \\
\hline SW Sodium & 1 & 3 & 2 & 2 & 4 & 4 \\
\hline SW Potas. & 2 & 1 & 3 & 3 & 4 & 4 \\
\hline SW ATPase & 1 & 1 & 2 & 2 & 3 & 4 \\
\hline FW ATPase & 1 & 1 & 1 & 1 & 2 & 4 \\
\hline $\mathrm{T} 4$ & 3 & 2 & 1 & 1 & 4 & 4 \\
\hline T3 & 2 & 3 & 1 & & & \\
\hline Insulin & 2 & 3 & 1 & & & 4 \\
\hline Contisol & 3 & 3 & 2 & 1 & 1 & 4 \\
\hline Stress factors & & - & - & - & - & - \\
\hline Glucose & - & - & - & - & - & - \\
\hline Glycogen & 2 & 1 & 3 & 3 & 3 & 4 \\
\hline Triglycerides & 3 & 2 & 2 & 2 & 1 & 4 \\
\hline Morph. PC & 2 & 3 & 2 & 1 & 2 & 4 \\
\hline Skin Guan. & 3 & 2 & 1 & 1 & 3 & 4 \\
\hline Immun. Resp. & 1 & & 2 & 3 & 4 & 4 \\
\hline Blond & & & & & & \\
\hline TOTALS & 31 & 29 & 29 & 26 & 40 & 60 \\
\hline
\end{tabular}


Willamette is higher than that of the other hatcheries, it will be difficult to partition the cause of greater adult contribution between better juvenile passage downstream and better smolt quality. Additional study of smolt indices will be required to resolve conflicting interpretations. In this regard, preliminary analysis of smolt quality data from 1990 suggests that smolt indices show greater development than they did in 1989 at some of the upper-river hatcheries. We anticipate that year-to year variation in smolt development at these hatcheries should provide a wider range of smolt quality to assess the reliability of indices. However, such a comparison should be done cautiously, since comparison of adult contribution of a single hatchery over several years assumes stable conditions of river flows, estuarine conditions, and near-ocean conditions.

It is anticipated that these studies will provide a suite of measurements that can be used to determine appropriate times for release of smolts from the hatcheries. The appropriate time for release would be based on the time when smolts achieve a physiological condition that would maximize their rate of downstream migration and survival. Assessment of smolt quality would be used to refine hatchery practices to improve survival, match the time of smolt releases to high river flows, and reduce the competition between hatchery-released smolts and migrating wild juvenile salmon. 


\section{LITERATURE CITED}

Barton, B. B., C. B. Schreck, R. D. Ewing, A. R. Hemmingsen, and R. Patino. 1985. Changes in plasma cortisol during stress and smoltification in coho salmon Oncorhvnchus kisutch. Gen. Comp. Endocrinol. 59:468-47 1.

Blackbum, J., and W. C. Clarke. 1987. Revised procedure for the 24 hour seawater challenge test to measure seawater adaptability of juvenile salmonids. Can. Tech. Rep. Fish. Aquat. Sci. No. 1515: 1-35.

Bucolo, G., and H. David. 1973. Quantitative determination of serum triglycerides by the use of enzymes. Clin. Chem. 19:475-482.

Clarke, W. C., and J. Blackbum. 1977. A seawater challenge test to measure smolting of juvenile salmon. Fish. Mar. Serv. Res. Dev. Tech. Rep. 705:1-11.

Dewilde, M. A., and A. H. Houston. 1967. Haemarological aspects of thermo-acclimatory process in the rainbow trout (Salmo gairdneri). J. Fish. Res. Board Can. 23:22672281.

Dickhoff, W. W., D. S. Darling, and A. Gorbman. 1982a. Thyroid function during smoltification of salmonid fish. In: Phvlogenetic Aspects of Thyroid Hormone Actions. Institute of Endocrinology, Gunma University eds., Gunma Symposia on Endocrinology, Vol. 19, p. 45-61, Center for Academic Publications Japan, Tokyo.

Dickhoff, W. W., L. C. Folmar, and A. Gorbman. 1978. Changes in plasma thyroxine during smoltification of coho salmon, Oncorhvnchus kisutch. Gen. Comp. Endocrinol. 36:229-232.

Dickhoff, W. W., L. C. Folmar, J. L. Mighell, and C. V. W. Mahnken. 1982b. Plasma thyroid hormones during smoltification of yearling and underyearling coho salmon and yearling chinook salmon and steelhead trout. Aquaculture 28:39-48.

Eales, J. G., M. Hughes, and L. Uin. 1981. Effect of food intake on diel variation in plasma thyroid hormone levels in rainbow trout, Salmo gairdneri. Gen. Comp. Endocrinol. 45:167-174.

Folmar, L. C., and W. W. Dickhoff. 1980. The par-r-smolt transformation (smoltification) and seawater adaptation in salmonids. A review of selected literature. Aquaculture $21: 1-37$.

Francis, R. C., W. G. Pearcy, R. Brodeur, J. P. Fisher, and L. Stephens. 1989. Effects of the ocean environment on the survival of Columbia River juvenile salmonids. In: "Quality and behavior of juvenile salmonids in the Columbia River estuary and nearshore ocean. Research Plan Final Report, Bonneville Power Administration Project 88-159, 76 p.

Giorgi, A. E., G. A. Swan, W. S. Zaugg, T. Coley, and T. Barila. 1988. Susceptibility of chinook salmon smolts to bypass systems at hydroelectric dams. North Am. J. Fish. Manag. 8:25-29.

Hoar, W. S. 1988. The physiology of smolting salmonids. In W. S. Hoar and D. J. Randall (editors), Fish physiology. Vol XIB Academic Press. San Diego. p. 275-343. 
Laidley, C. W., and J. F. Leatherland. 1988. Circadian studies of plasma cortisol, thyroid hormone, protein, glucose and ion concentration, liver glycogen concentration and liver and spleen weight in rainbow trout, \$almo gnirdperi RicBardisom $\quad c \quad h \quad$ e $m$. Physiol. 89A: 495-502.

Nishioka, R. S., G. Young, H. A. Bern, W. Jochimsen, and C. Hiser. 1985. Attempts to intensify the thyroxin surge in coho and king salmon by chemical stimulation. Aquaculture 45:2 15-225.

Parametrix, Inc. 1983 Physiological monitoring of smoltification and stress in mid-Columbian chinook and steelhead, 1983. Draft Report. Bellevue Washington. 54 p.

Patiño, R., C. B. Schreck, J. L. Banks, and W. S. Zaugg. 1986. Effects of rearing conditions on the developmental physiology of smolting of coho salmon. Trans. Am. Fish. Soc.115:828-837.

Plisetskaya, E., W. W. Dickhoff, T. L. Paquette, and A. Gorbman. 1986. The assay of salmon insulin by homologous radioimmunoassay. Fish Physiol. Biochem. 1:35--1 1.

Plisetskaya, E. M., P. Swanson, M. G. Bernard, and W. W. Dickhoff. 1988. Insulin in coho salmon (Oncorhvnchus kisutch) during the parr to smolt transformation. Aquaculture $72: 151-164$.

Redding, J. M., F. H. Everest and C. B. Schreck. 1987. Physiological effects on coho salmon and steelhead of exposure to suspended solids. Trans. Am. Fish. Soc. 116:737-744.

Redding, J. M., C. B. Schreck, E. K. Birks, and R. D. Ewing. 1984. Cortisol and its effects on plasma thyroid hormone and electrolyte concentration in fresh water and during seawater acclimation in yearling coho salmon, Oncorhvnchus kisutch. Gen. Comp. Endcrinol. 56: 146- 155.

Schiewe, M. H., D. M. Miller, E. M. Dawley, R. D. Ledgerwood, and R. L. Emmett. 1989. Quality and behavior of juvenile salmonids in the Columbia River estuary and nearshore ocean. Research Plan Final Report, Bonneville Power Administration Project 88-159, 76 p.

Soivio, A., and E. Virtanen. 1985. The quality and condition of reared Salmo salar smolts in relation to their adult recapture rate. Aquaculture 45:335-343.

Staley, K. B. 1984. Purine deposition in the skin of juvenile coho salmon, Oncorhynchus kisutch. M.S. Thesis, Oregon State University, Corvallis, OR 63 p.

Tripp, R. A., A. G. Maule, C. B. Schreck, and S. L. Kaattari. 1987. Conisol mediated suppression of salmonid lymphocyte responses in vitro. Developmental and Comparative Immunology 11:565-576.

Warren, J. 1989. Augmented fish health monitoring. Annual Report 1988-1989, Project 87119, 39 p. Bonneville Power Administration.

Wedemeyer, G. A., and D. J. McLeay. 198 1. Methods for determining the tolerance of fishes to environmental stressors. In: "Stress and Fish", A. D. Picketing, ed. Academic Press, Inc. London. p. 247-275. 
Wedemeyer, G. A., and W. T. Yasutake. 1977. Clinical methods for the assessment of the effects of environmental stress on fish health. U.S. Dept. Interior, Fish \& Wildlife Service, Technical Paper 89:1 - 18.

Winans, G. A. 1984. Multivariate morphometric variability in Pacific salmon: technical demonstration. Can. J. Fish. Aquat. Sci. 41: 1150-1 159.

Winans, G. A., and R. S. Nishioka. 1987. A multivariate description of change in body shape of coho salmon (Oncorhvnchus Aisutgh) during smeohifucation.t $u \quad r \quad e$ $66: 235-245$.

Young, G. 1986. Cortisol secretion in vitro by the interrenal of coho salmon (Oncorhvnchus kisutch): relationship with plasma thyroxine and plasma cortisol. Gen. Comp. Endocrinol. 63: 191-200.

Zar, J. H. 1974. Biostatistical Analysis. Prentice Hall. Englewood Cliffs, NJ. 620 p.

Zaugg, W. S. 1982. A simplified preparation for adenosine triphosphatase determination in gill tissue. Can. J. Fish. Aquat. Sci. 39:215-217.

Zaugg, W. S. 1989. Migratory behavior of underyearling Oncorhvnchus tshawvtscha and survival to adulthood as related to prerelease gill $\left(\mathrm{Na}^{+}-\mathrm{K}^{+}\right)-\mathrm{ATPase}$ development. Aquaculture 82:339-353.

Zaugg, W. S., and L. F. McLain. 1972. Changes in gill adenosinetriphosphatase activity associated with parr-smolt transformation in steelhead trout, coho, and spring chinook salmon . J. Fish. Res. Board Can. 29:167-171. 
APPENDIX 1

Field Notes 


\section{GENERAL}

Field sampling of the 1987-brood spring chinook salmon for BPA project X9-46 commenced in March 1989 and continued through May. The following describes hatcher) collection procedures, and protocols for collecting blood and tissue samples which were derived by the end of the sampling season. Deviations from these procedures will be described separately for specific hatcheries.

The sample collecting team obtained blood and tissue samples approximately every 2 weeks at each hatchery. Not all tissues were taken on each visit, however. Samples of gill filaments for ATPase, plasma for thyroxine ( $\mathrm{T}_{4}$ and $\mathrm{T}_{3}$ ), insulin, cortisol (including secondary stress), and photographs for morphometrics were taken biweekly, whereas skin for guanine, liver for glycogen and triglycerides, blood for electrolytes, glucose, total protein, and smears, and muscle for water content were taken approximately monthly. Saltwater challenge tests were performed once or twice before release (see METHODS) and immune response was measured at Dworshak and Warm Springs NFH, and at the Willamette Hatchery on each biweekly visit (see METHODS).

On the first visit to each hatchery an appropriate work area was found. Specific raceways were identified and subsequent collections were from those raceways. Sufficient plasma for all plasma parameters under investigation was not available from a single fish. Therefore, two 15-fish collections were taken. In addition, another 15-fish sample was obtained for the secondary stress test.

\section{SAMPLING PROCEDURES}

Samples taken from, and measurements taken on, each group are outlined below:

Group I Biweekly (secondary stress); length (mm), weight (g), sex. plasma (cortisol), liver condition.

A suess bucket (a 5-gallon bucket with holes drilled in the sides and bottom) was suspended from a fixture along the wall of a raceway such that the bottom of the bucket was well below the surface of the water. Approximately 15 fish were then dip-netted from the raceway and deposited into a separate bucket of water from which exactly 15 fish were poured, with water, into the stress bucket. The water level was adjusted by raising the stress bucket so that the backs (not the dorsal fin) of the median-sized fish were barely 
under water. The stress bucket was secured in this position and fish were ailowed to remain under those conditions for 1 hour. The test was terminated by placing the fish in a lethal concentration of $\mathbf{M S}-222$ (200 mg/L) after which they were transported rapidly to the work area where lengths and weights were measured and recorded. Each fish was blotted, then the tail was severed with a scalpel blade at the caudal peduncle. Blood was collected in a heparinized Pasteur pipet [prepared prior to field season by filling and emptying each pipet with an ammonium heparin solution (1,000 units $/ \mathrm{ml})$ and drying at room temperature]. As blood flow ceased, the pipet containing blood was placed, tip down, in a 400ul polyethylene microfuge tube and blood was allowed to drain. After all 15 fish had been processed. an! blood remaining in the pipets was gently blown into the microfuge tube. The tubes were centrifuged in a Beckman Model E microfuge for 3 minutes. The supernatant plasma was drawn out of the individual tubes with an unheparinized Pasteur pipet and placed in a labeled microfuge tube. Plasma was stored on dry ice in the field, then transferred to and stored in a freezer $\left(-20^{\circ} \mathrm{C}\right)$ at Cook, Washington until delivery to the appropriate laborator: conducting the analysis. Carcasses were opened, sex determined, and kidneys and livers examined. Total time for processing 15 fish was less than 45 minutes.

Group 11 Biweekly; length, weight, sex, hematocrit, plasma (cortisol, glucose). Monthly; plasma (electrolytes, total protein), blood (smear).

During the 1 -hour stress challenge, Group II fish used to obtain plasma for cortisol and glucose were collected and processed. Approximately 15 fish were netted from a raceway and deposited in a lethal concentration of MS-222 (200 mg/L). Care was taken not to startle fish in the raceway prior to netting and quickly placing them into the MS -222. Plasma was collected as indicated above for Group I, but these additional steps were added: as blood flow slowed with each fish, a microhematocrit tube (ammonium heparin, 3 units/tube, Kimble) was filled with blood. The tube was plugged with clay, then placed on ice until all 15 fish had been processed. The tubes were then centrifuged in a microhematocrit centrifuge for 3 minutes. and hematocrit values determined and recorded. When collecting monthly samples for plasma elecuolytes and total protein, and for blood smears, the protocol was altered considerably. It became important to collect as much blood as possible from each fish to have sufficient plasma to provide for all assays. Therefore, to prevent reduced blood volumes from fish that had been dead too long, subgroups of 6 to 9 fish were collected at one time. After the first subgroup of fish was processed, the second subgroup (making a total of 15 fish) was collected and processed. Lengths and weights were recorded, the tail severed, and blood collected in an ammonium heparinized Caraway tube (370 $\mu$, Monoject). After the tube was full, a hematocrit tube was filled. If a fish did not yield enough blood to fill a Caraway tube, the hematocrit tube 
was filled by placing the tip against the end of the Caraway tube and allowing capillary action to fill it. The hematoctit tube was plugged and placed on ice. A blood smear was prepared by spotting a drop of blood from the Caraway tube onto a microscope slide. The blood was smeared across the slide with a second slide and then allowed to air dry. The Caraway tube was capped and placed in a Serofuge. After the first subgroup of fish was finished, the Caraway tubes were centrifuged for $\mathbf{5}$ minutes in the Serofuge, removed, scored, and broken at the serum-buffy coat interface. The plasma was blown into a labeled 1.5-ml microfuge tube and placed on dry ice. The above steps were repeated for the second subgroup of fish. The 15 microhematocrit tubes were centrifuged for 3 minutes in a hematocrit centrifuge, hematoctits determined, and values recorded. The tubes were then broken at the packed cell-plasma interface, and the plasma was expelled into a $400 \mu$ microfuge tube, frozen on dry ice, and stored for cortisol analysis. Blood smear slides were placed in 100\% methanol for at least 15 minutes, removed and placed in slide racks, then stored for later reading. A ventral incision was made, sex, liver, and kidney condition noted.

Group III Biweekly; photographs (morphometrics), thyroid hormones (T3 and $\mathrm{T}_{4}$, insulin, and gill ATPase.

Monthly; muscle (tissue water), liver (glycogen, triglycerides), skin (guanine).

This group of 15 fish was collected after the other groups had been sampled. The fish were dip-netted from the raceway, placed in a bucket of water, and carried to the work area. Individuals were taken alive from the bucket, one at a time, killed by a blow to the head, blotted, measured, and weighed. Individuals were placed on a lighted camera stand against a white background. A label containing the date, hatchery, and group number was placed next to the fish, and various morphometric landmarks were marked by placement of pins. A photograph was taken using an Olympus OM-4T camera, f-stop 11, with Kodak TMAX 100 B/W film. Blood was collected and plasma separated as indicated above for Group I fish, with the additional precaution taken of placing the whole blood on ice until all fish had been processed. Gill filaments were trimmed from the lower half of two to four arches (depending on the size of the fish) and placed in a pyrex test tube with $1 \mathrm{ml}$ of SEI (sucrose-EDTA-imidazole). The test tubes were covered with Parafilm and placed on dry ice after the last fish was processed. Samples were transported to the laboratory where they were stored at $-80^{\circ} \mathrm{C}$ until analyzed. A ventral incision was made, and sex and liver condition noted and recorded.

When collecting the monthly samples, which included those for liver glycogen and triglycerides, skin guanine, and muscle water content, along with those listed above. the 
following procedure was carried out before excising the gill filaments and immediately after collecting the blood: a ventral incision was made and sex and liver condition noted. A 0.10 to $0.20 \mathrm{~g}$ piece of liver was cut from the posterior tip of the liver lobe, placed in a tared, labeled vial, and weighed to $0.01 \mathrm{~g}$. About $5 \mathrm{ml}$ of liquid nitrogen was placed in the vial with the liver to quick-freeze the tissue, preserving the glycogen from enzymatic degredation. After the liquid nitrogen had evaporated, the vial was capped and placed on dry ice (within 2 minutes). A second piece of liver (0.05 to $0.1 \mathrm{~g}$ ) was excised and placed in a labeled test tube (for triglyceride analysis), the tube capped with Parafilm and placed on dry ice. Two parallel incisions were made $1 \mathrm{~cm}$ apart, $5 \mathrm{~mm}$ deep, midway between the back of the head and the front of the dorsal fin insertion, to a point $5 \mathrm{~cm}$ beyond where they were started. A perpendicular incision was made connecting the two parallel lines at the front end. One comer of the skin was grasped with forceps and peeled back toward the tail. A scalpel was used to help separate muscle and fat tissue from the skin. The flap of skin (about 1 x $5 \mathrm{~cm}$ ) was cut free, placed in a labeled tube, capped with Parafilm, and placed on dry ice for later analysis of guanine. A piece of white muscle ( 0.1 to $0.2 \mathrm{~g}$ ) was carved from the area exposed by removal of the skin, placed in a tared, labeled vial, and weighed to the nearest $0.01 \mathrm{~g}$. The vial was then capped and placed on dry ice (for tissue water analysis). All tissue samples were stored at Cook, Washington at $-80^{\circ} \mathrm{C}$ until delivery to the appropriate laboratory. Time to complete sampling was less than 1.75 hours.

\section{Group IV Saltwater challenge.}

Saltwater challenges were performed prior to releases. An additional 20 fish were required from each raceway for each challenge. Salt water was made up on site by adding approximately $80 \mathrm{~L}$ hatchery water to $2.9 \mathrm{~kg}$ Instant Ocean Salts in a $128 \mathrm{~L}$ plastic container. The salinity was measured with a refractometer and either water or salt was added to adjust the salinity to a concentration of $30 \mathrm{ppt}$. The plastic containers were placed or suspended in running hatchery water to maintain the temperature. Water in the container was aerated using an air pump and air stones. Twenty fish were dip-netted from the raceway, placed in a bucket of water and carried to the challenge site, then netted from the bucket and placed into the salt water. The container was covered and fish were maintained under these conditions for $\mathbf{2} 4$ hours after which the fish were removed by netting and placed in a bucket containing salt water. Fish were removed one at a time from the salt water, killed by a blow to the head, rinsed in fresh water, weighed, and measured. Plasma was collected as indicated for Group I above. Gill filaments were excised, placed in SEI. and held on dry ice until arrival at the laboratory where they were stored at $-80^{\circ} \mathrm{C}$ until analyzed for ATPase activity. A ventral incision was made and the sex and liver condition 
noted. All mortalities occurring during the challenge were counted, weighed, and measured.

\section{SAMPLED FISH}

The following tables list, for individual fish, fork lengths (mm), weights (g), sex ( $\mathrm{F}$ = female, $\mathrm{M}=$ male, $\mathrm{Md}$ = developing male, $\mathrm{Mp}$ = fully developed, precocious male), and abnormal liver condition $(\mathrm{Lp}=$ pale liver, $\mathrm{Lm}=$ mottled liver, also $\mathrm{An}=$ anemic as assessed by light-colored blood). Also noted are any variations from the general sampling procedure and other observations that may have affected some of the parameters being measured, including water temperature at the time of sampling and time of day at which fish from the stress challenge were killed for processing (for use in approximating the time at which the various samples were collected). The raceway (RWY) number for each group is given. 


\begin{tabular}{|c|c|c|c|c|c|c|c|c|c|c|c|c|c|}
\hline \multicolumn{2}{|c|}{ Dworshak } & \multicolumn{3}{|c|}{ Md=developing } & ale; $M p=$ & =fully de & eveloped, & precocious & $1 s$ male; & \multicolumn{3}{|c|}{ An=anemic } & \multirow[b]{3}{*}{ Other } \\
\hline Lp=pale & \multicolumn{2}{|c|}{ liver; Lm=motlled } & \multicolumn{3}{|c|}{ liver; $T=$ coded } & \multicolumn{2}{|c|}{ wire tag; B=branded } & \multirow[b]{2}{*}{$(\mathrm{mm})$} & \multirow[b]{2}{*}{ Wt (g) } & \multirow[b]{2}{*}{ Sex } & & & \\
\hline Fish & FL $(\mathrm{mm}$ & Wt (a) & $\operatorname{sex} 1$ & $\mathrm{HCl}$ & \begin{tabular}{|l|l} 
Cond & \\
\end{tabular} & Other & Fish & & & & $\mathrm{HCl}$ & Cond & \\
\hline $3 / 8 / 89$ & \begin{tabular}{|l|} 
Group 1 \\
\end{tabular} & Rwy 11 & 950 & pm te & $m p=5$ & & $3 / 8 / 89$ & Group II & $\begin{array}{|ll|}\text { Rwy } & 11 \\
\end{array}$ & Temp & $=5$ & & \\
\hline 1 & 150 & 3751 & \begin{tabular}{|l|}
$M$ \\
\end{tabular} & & $\begin{array}{llll}1 & 1 & 1 & 1 \\
\end{array}$ & & 1 & \begin{tabular}{r|}
114 \\
\end{tabular} & 162 & \begin{tabular}{|l|l|}
$F$ \\
\end{tabular} & 29 & 1093 & \\
\hline 2 & 125 & \begin{tabular}{ll|l}
2151 \\
\end{tabular} & $M$ & & 1101 & & 2 & 134 & 2551 & $M$ & 33 & 106 & \\
\hline 3 & 137 & $265 \mid$ & $M$ & & 1031 & & 3 & 119 & 182 & $F$ & 32 & 108 & \\
\hline A & 161 & $\$ 0615$ & $F$ & & -1189 & & 41 & 119 & 187 & $M$ & 40 & $\begin{array}{lll}1 & 1 & 1 \\
\end{array}$ & \\
\hline 5 & 122 & 9 & & 1.0 & 96 & & 5 & \begin{tabular}{l|l}
133 & 25 \\
\end{tabular} & \begin{tabular}{|l|l|l|}
5 & 4 & $M$ \\
\end{tabular} & 32 & 1 & of 1.081 & $\mathrm{Lm}$ \\
\hline 6 & 137 & $277 \mid F$ & $\mathbf{F}$ & & 1077 & & 6 & 125 & 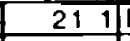 & $F$ & 38 & 108 & \\
\hline 7 & 135 & $27 \quad 21$ & $F$ & & 1106 & & 7 & 118 & 182 & $F$ & 34 & 1.108 & \\
\hline 8 & 109 & $\begin{array}{ll}3 & 4 \\
\end{array}$ & $F$ & & 1035 & & 8 & 125 & 221 & $M$ & 39 & 0932 & \\
\hline 9 & 99 & 1035 & $F$ & & 1062 & & 9 & 132 & 278 & $M$ & 34 & 1.209 & \\
\hline 10 & 130 & $231 F$ & $\mathbf{F}$ & & 1047 & & 10 & 120 & 193 & $\mathrm{~F}$ & 34 & 1117 & \\
\hline 11 & \begin{tabular}{l|l|}
131 \\
\end{tabular} & $239 \mathrm{~F}$ & $F$ & & $1063 \mathrm{~L}$ & Lp & 11 & 116 & 1781 & $\mathbf{F}$ & 35 & 1096 & \\
\hline 12 & 161 & 6691 & Md & & $1128 \mathrm{~L}$ & Lp & 12 & 119 & 18.3 & $M$ & 42 & 1.086 & \\
\hline 13 & 127 & $22-1$ & $E$ & & 10891 & Lm & 13 & 119 & 191 & $\mathrm{~F}$ & 39 & 1113 & \\
\hline 14 & 121 & $2 n$ & $F$ & & 1129 & & 14 & 119 & 1861 & $\bar{M}$ & 638 & 1.1044 & \\
\hline 15 & 104 & $7231 \mathrm{~F}$ & $\mathrm{~F}$ & & 10931 & & 15 & 180 & 617 & $\mathrm{M}$ & 33 & 1058 & \\
\hline Ave & 131 & 268 & & & $\begin{array}{ll}1 & 09\end{array}$ & & suo & 126 & 231 & & 35 & 1088 & \\
\hline su & $<1$ & 748 & & & 0041 & & $\overline{\mathbf{S E}}$ & 16 & 112 & & 4 & 0056 & \\
\hline $\mathbb{E}$ & 5 & \begin{tabular}{|l|}
38 \\
\end{tabular} & & & 0011 & & & 4 & 29 & & IL & 0.0141 & \\
\hline Fish & FL $\quad(\mathrm{mm}$ & WI $(\mathrm{g})$ & Sex & Hol & Cond & Ot her & $F i s h$ & IFL $(\mathrm{m} \mathrm{m})$ & $W t(g)$ & $\operatorname{sex}$ & $\mathrm{Hct}$ & Cond & Tother \\
\hline 3.8189 & Group III & Rwy 11 & temp & $0=5$ & & & $3 / 15 / 89$ & Group 1 & Awy_11: & 1140 & a m, & $\operatorname{tem} p=5$ & \\
\hline 1 & 120 & 193 & $M$ & & 1117 & & \begin{tabular}{r|}
1 \\
\end{tabular} & 110 & & $F$ & & & $\mathrm{Lm}$ \\
\hline 2 & 140 & \begin{tabular}{l|l}
334 & 1 \\
\end{tabular} & Md & & 1217 & & 2 & 118 & 177 & $F$ & & 1077 & \\
\hline 3 & 131 & $249 \mathrm{~F}$ & $F$ & & 1108 & & 3 & $\begin{array}{lll}11 & 17 \\
\end{array}$ & 167 & $F$ & & 1043 & \\
\hline 4 & 137 & 2981 & $M$ & & $1+59$ & & 4 & 118 & 176 & $M$ & & 1071 & \\
\hline 5 & 1211 & $18 \quad 7$ & $M$ & & $10,561 \mathrm{c}$ & descaled & 51 & 1341 & {$\left[\begin{array}{lll}2 & 7^{-} & 3\end{array}\right]$} & $M$ & & 1.135 & \\
\hline 6 & 12 & $194 \mid \mathrm{M}$ & & 1 & $043 L p$ & & \begin{tabular}{l|l}
6 & \\
\end{tabular} & \begin{tabular}{|l|l|}
118 & 19 \\
\end{tabular} & $941 \mathrm{M}=6$ & $F=$ & & -1.011 & 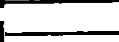 \\
\hline 7 & 1391 & 314 & $M$ & & $\begin{array}{|ll|}1 & 169 \\
\end{array}$ & & 7 & 115 & 155 & $F$ & & $\begin{array}{llll}1 & 0 & 1 & 1\end{array}$ & $\mathrm{Lm}$ \\
\hline 8 & 125 & $219 . F$ & $F$ & & 1121 & & 8 & 119 & 1831 & $M$ & & $1086 \mathrm{~L}$ & LP \\
\hline 9 & 128 & 2275 & $F$ & & 1082 & & 9 & 121 & 184 & $F$ & & 1039 & \\
\hline 10 & 138 & $284 \mathrm{~F}$ & $\mathrm{~F}$ & & 1081 & & 10 & 116 & 18 & $F$ & & 1.153 & \\
\hline 11 & 125 & 211 & $M$ & & 1075 & & 11 & 121 & 187 & $M$ & & 10561 & $\mathrm{Lm}$ \\
\hline 12 & 145 & $\begin{array}{lll}36 & 1 & 1 \\
\end{array}$ & Md & & 1184 & & 12 & 132 & 233 & $M$ & & 1013 & \\
\hline 13 & 129 & 2431 & $F$ & & 1132 & & 13 & 130 & 243 & $F$ & & 1.106 & \\
\hline 14 & 124 & 2071 & $\mathrm{M}$ & & 1086 & & 14 & 140 & $\begin{array}{lll}29 & 3 & 1\end{array}$ & Md & & 1068 & $\mathrm{Lm}$ \\
\hline 15 & 121 & \begin{tabular}{ll|l}
8 & 3 & 1
\end{tabular} & $M$ & & 1033 & & 15 & 129 & 274 & $F$ & & 1276 & \\
\hline Ave & 130 & 247 & & & 1111 & & Ave & 123 & 207 & & & 1082 & \\
\hline SO & 8 & $\begin{array}{ll}5 & 8\end{array}$ & & & 054 & & $\mathbf{D}$ & 8 & 47 & & & 0.07 & \\
\hline$\overline{\mathbf{S E}}$ & 2 & 15 & & & 0014 & & SE & 2 & 12 & & & 0.019 & \\
\hline Fish & $F \mathrm{~L} \quad \mathrm{~mm}$ & Wt (g) & Sex & $\mathrm{HCl}$ & Cond & Other & Fish & FL $(\mathrm{mm})$ & Wt (g) & $\operatorname{sex}$ & $\mathrm{HCl}$ & Cond & Other \\
\hline $3.15,89$ & Group II & Rwy 11 & temp & & & subgre $\$$ & $3 / 15 / 89$ & Group III & Rwy 11: & temp & & & \\
\hline \begin{tabular}{r|}
1 \\
\end{tabular} & 124 & 218 & Md & 30 & 1143 & 1 & \begin{tabular}{r|}
1 \\
\end{tabular} & 110 & 158 & $F$ & & 1187 & \\
\hline 2 & 128 & 2211 & $M$ & 27 & 1054 & $\mathrm{Lm}$ & 2 & 119 & 199 & Md & & 1181 & \\
\hline 3 & 120 & 187 & $M$ & 33 & 1082 & 1 & 3 & 127 & $\begin{array}{lll}2 & 2 & 3\end{array}$ & $F$ & & 1089 & \\
\hline $\begin{array}{l}4 \\
-5\end{array}$ & 126 & 2251 & $M$ & 24 & 1125 & 1) & 4 & 178 & $\begin{array}{lll}68 & 1\end{array}$ & Md & & 1207 & \\
\hline & 123 & 215 & $F$ & 34 & 1161 & 11 & 5 & 138 & 278 & $F$ & & 1058 & \\
\hline 6) & 1.32 & 2461 & Md & 38 & $\begin{array}{ll}1 & 07\end{array}$ & 1 & 6 & 132 & 262 & Md & & 1139 & \\
\hline 7 & 110 & 158 & $M$ & 34 & 1187 & 1 & 7 & 121 & 188 & $F$ & & 1061 & \\
\hline 8 & 133 & 2621 & Md & 37 & 1114 & 1 & 8 & 112 & 156 & $F$ & & 1.11 & \\
\hline 9 & 130 & 231 & $F$ & 24 & 1047 & 1 & 9 & 119 & 189 & $F$ & & 1122 & \\
\hline 10 & 132 & 246 & $M$ & 34 & $\begin{array}{ll}1 & 07 \\
\end{array}$ & 1 & 10 & 108 & 14 & $M$ & & 1111 & \\
\hline 111 & 1241 & 225 & $F$ & 25 & 118 & 2 & $\begin{array}{ll}11 \\
\end{array}$ & 120 & 20 & $F$ & & 1157 & \\
\hline 12 & 120 & 179 & $\mathrm{M}$ & 34 & 1036 & 2 & 12 & 107 & 142 & $M$ & & 1.159 & $\mathrm{Lm}$ \\
\hline i 3 & 119 & 206 & Add & 31 & 1222 & 2 & 13 & 127 & $\begin{array}{lll}25 & 3\end{array}$ & Md & & 1235 & \\
\hline$-i 4$ & 132 & 245 & ind & 30 & 1065 & 2 & 14 & 170 & 505 & $M$ & & 1028 & \\
\hline 15 & 120 & 194 & $\bar{M}$ & 30 & 1123 & 2 & 15 & 147 & 327 & $F$ & & 1029 & \\
\hline Ave & 125 & 217 & & 31 & $\begin{array}{llll}1 & 1 & 1 & 2 \\
\end{array}$ & & Ave. & 129 & 26 & & & 1125 & \\
\hline 50 & 6 & 28 & & 5 & 0057 & & $\$ 0$ & 21 & 149 & & & 0064 & \\
\hline 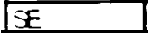 & 2 & 07 & & 1 & 0015 & & 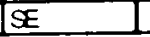 & 61 & $\begin{array}{ll}3 & 8\end{array}$ & & & 0016 & \\
\hline
\end{tabular}




\begin{tabular}{|c|c|c|c|c|c|c|c|c|c|c|c|c|c|}
\hline Fish $\#$ & FL $(\mathrm{mm}$ & Wt $(g)$ & ISex & \begin{tabular}{l|l|}
$x$ & $\mathrm{HCl}$ \\
\end{tabular} & Cond & Other & Fish & $F L \quad(\mathrm{~mm})$ & Wt & Sex & $\mathrm{HCl}$ & Cond & Other \\
\hline $3: 15 / 89$ & Group 1 & $\begin{array}{|ll|}R w y & 12 \\
\end{array}$ & 400 & Dpm te & $\mathrm{emp}=$ & & $3 / 15 / 89$ & Group ॥ & Rwy 12 . & temp & & & subgrp \\
\hline 1 & 121 & 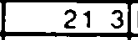 & $M$ & & \begin{tabular}{|l|}
1202 \\
\end{tabular} & & 1 & 117 & 172 & $M$ & 28 & 1074 & An 1 \\
\hline 2 & 115 & 172 & $M$ & & 1131 & & 2 & 128 & 239 & $M$ & 28 & 114 & 1 \\
\hline 3 & 117 & 184 & $M$ & & 1149 & & 3 & 140 & $\begin{array}{lll}34 & 1 \\
\end{array}$ & Md & 26 & 1243 & 1 \\
\hline 4 & 119 & 185 & $M$ & & 1098 & & 4 & 128 & 245 & $M$ & 36 & 1168 & 1 \\
\hline 5 & 1241 & 712 & $F$ & & 1112 & & 5 & 121 & 201 & $F$ & 33 & 1135 & 1 \\
\hline 6 & 119 & 178 & $F$ & & 1056 & An & 6 & 160 & 52.6 & $F$ & 30 & 1284 & 1. \\
\hline 7 & 127 & 212 & $M$ & & 1035 & $A n$ & 7 & 135 & 282 & $M$ & 35 & 1146 & 1 \\
\hline 8 & 130 & 242 & $F$ & & 1102 & & 8 & 133 & 262 & $F$ & 36 & 1114 & 1 \\
\hline 9 & 139 & 302 & $\mathrm{Md}$ & & 1125 & & 9 & 165 & 52.5 & Md & 27 & 1169 & 1 \\
\hline 10 & 141 & 293 & Md & & 1045 & & 10 & 115 & 171 & $F$ & 22 & 1124 & 2 \\
\hline 11 & 132 & 27 & $F$ & & 1174 & & 11 & 114 & 18 & $F$ & 19 & 1215 & 2 \\
\hline 12 & 135 & 291 & $M$ & & 1.183 & & 12 & 115 & 178 & $M$ & 16 & 117 & 2 \\
\hline 13 & 136 & $\begin{array}{lll}30 & 3 \\
\end{array}$ & $F$ & & 1205 & & 13 & 125 & 227 & $M$ & 26 & 1162 & 2 \\
\hline 14 & 141 & 346 & $M$ & & 1234 & & 14 & 124 & 203 & Md & 22 & 1065 & 2 \\
\hline 15 & & & & & & & 15 & 161 & 454 & And & 29 & 1088 & 2 \\
\hline Ave & 128 & 243 & & & 1132 & & Ave. & 132 & 28 & & 28 & \begin{tabular}{ll|}
1 & 153 \\
\end{tabular} & \\
\hline SO & 9 & 57 & & & 0062 & & 50 & 17 & 124 & & 6 & $\begin{array}{lll}0 & 0 & 6\end{array}$ & \\
\hline$S E$ & 2 & $\begin{array}{l}15 \\
\end{array}$ & & & $\begin{array}{llll}0 & 017 \\
\end{array}$ & & SE & 4 & 32 & & 2 & 0016 & \\
\hline Fish $\because$ & FL $(\mathrm{mm}$ & Wt (g) & Sex & $1 \mathrm{Hcl}$ & Cond & Other & Fish & FL $(\mathrm{mm})$ & Wt (g) & {$[\operatorname{sex}]$} & Hct & Cond & Other \\
\hline $3: 25 / 89$ & Group_li & Rwy-12 & temp & & & & $3 / 16 / 89$ & Group I P & Rwy 13. & 845 & $a m, i$ & $\operatorname{tem} p=$ & \\
\hline 1 & \begin{tabular}{|l|}
121 \\
\end{tabular} & 197 & Md & & 1112 & & \begin{tabular}{|l|} 
\\
\end{tabular} & 1221 & $\begin{array}{r}214 \\
\end{array}$ & $F$ & & $|.170|$ & \\
\hline 2 & 110 & 156 & $M$ & & 1172 & & 2 & 118 & 174 & $F$ & & 1059 & \\
\hline 3 & 161 & 502 & Md & & 1203 & & 3 & 117 & $\begin{array}{lll}1 & 6 & 3 \\
\end{array}$ & $F$ & & 1018 & $\mathrm{Lm}$ \\
\hline 4 & 141 & 316 & $F$ & & 1127 & & 4 & 115 & 172 & $F$ & & 1131 & An \\
\hline 5 & 115 & $\begin{array}{lll}17 & 3 \\
\end{array}$ & $F$ & & 1138 & & 5 & 114 & 168 & $\bar{M}$ & & 1.134 & \\
\hline 6 & 108 & 149 & $F$ & & 1183 & & 6 & 110 & 142 & $F$ & & 1067 & \\
\hline 7 & 127 & 238 & $M$ & & 1162 & & 7 & 110 & 147 & $M$ & & $1 \quad 104$ & \\
\hline 8 & 126 & 218 & $F$ & & $\begin{array}{lll}1 & 09 \\
\end{array}$ & & 8 & 110 & 137 & $F$ & & 1029 & \\
\hline 9 & 122 & $\begin{array}{ll}21 & 6 \\
\end{array}$ & $M$ & & $\begin{array}{ll}1 & 19 \\
\end{array}$ & & 9 & 122 & 196 & $M$ & & 1079 & \\
\hline 10 & 113 & 158 & $F$ & & 1095 & & 10 & 132 & 24.1 & $F$ & & 1.048 & \\
\hline 11 & 134 & 288 & $\bar{M}$ & & $\begin{array}{ll}112 \\
\end{array}$ & & 11 & 130 & 241 & $F$ & & 1097 & \\
\hline 12 & 118 & 184 & $F$ & & 112 & & 12 & 130 & 25 & $M$ & & \begin{tabular}{ll|}
1 & 138 \\
\end{tabular} & \\
\hline 13 & 135 & 34 & $F$ & & 1382 & An Lm & 13 & 125 & 222 & $F$ & & 1.137 & \\
\hline 14 & 125 & 20 & $F$ & & 1024 & & 14 & 139 & 311 & Ma & & $\begin{array}{ll}1 & 158 \\
\end{array}$ & \\
\hline 15 & 157 & 439 & $F$ & & 1.134 & & 15 & 147 & 381 & $F$ & & 1199 & \\
\hline Ave & 128 & 252 & & & 1.15 & & Ave & 123 & $\begin{array}{lll}2 & 1 & 1\end{array}$ & & & 1.105 & \\
\hline so & -16 & 106 & & & 00791 & & $\mathbf{S O}$ & 11 & 68 & & & 0055 & \\
\hline $\mathscr{\mathbb { E }}$ & 4 & 27 & & & $\begin{array}{lll}0 & 02\end{array}$ & & $\mathscr{E}$ & 3 & \begin{tabular}{|l|}
17 \\
\end{tabular} & & & 0014 & \\
\hline Fish $\#$ & $\mathrm{FL} \quad \mathrm{mm}$ & Wt $(g)$ & $\operatorname{sex}$ & Hct & Cond & Other & Fish & $F L(\mathrm{~mm})$ & $\mid W I \quad(g)$ & Sex & Hct & Cond & Olher \\
\hline 3.16 .89 & Group II & Rwy 13 & temp & & & subgrp & $3 / 16 / 89$ & Group III & Rwy 13. & temp & $p=$ & & \\
\hline 1 & 134 & \begin{tabular}{|l|}
261 \\
\end{tabular} & $F$ & 28 & 1085 & 1 & 1 & 1231 & $\begin{array}{ll}21 & 2\end{array}$ & $M$ & & 11391 & \\
\hline 2 & 125 & $\begin{array}{ll}21 & 4 \\
\end{array}$ & $\mathrm{M}$ & 32 & 1096 & 1 & 2 & Ln? & 17,71 & $F$ & & .1088 & \\
\hline 3 & 124 & 229 & $F$ & 37 & 1201 & 1 & 3 & 133 & 272 & $F$ & & 1156 & \\
\hline 4 & 127 & $\begin{array}{lll}23 & 1 \\
\end{array}$ & $\bar{F}$ & 33 & 1128 & $\mathrm{Lm}$ & 4 & 113 & $\begin{array}{ll}16 & 11 \\
\end{array}$ & 14 & & 1116 & \\
\hline 5 & 114 & 166 & $F$ & 35 & 112 & 1 & 5 & 126 & 216 & $F$ & & 108 & \\
\hline 6 & 117 & 178 & $M$ & 39 & 1111 & 1 & 6 & 137 & $\begin{array}{lll}3 & 1 & 9 \\
\end{array}$ & Md & & 1241 & \\
\hline 7 & 141 & 347 & $\mathrm{Md}$ & 29 & 1238 & 1 & 7 & 98 & 105 & $F$ & & 1.116 & \\
\hline 8 & 129 & 25 & $M$ & 35 & 1165 & 1 & 8 & 111 & 172 & $F$ & & 1258 & \\
\hline 9 & 136 & 30 & $F$ & 36 & 1193 & 1 & 9 & 130 & 2461 & $M$ & & 112 & \\
\hline 10 & 150 & 382 & $F$ & \begin{tabular}{|l|}
411 \\
\end{tabular} & 1.132 & 1 & 10 & 122 & 24 fi & $M$ & & 1201 & \\
\hline 11 & 11 & $31-15$ & $31 \mathrm{M}$ & $11-2$ & $31 \quad 1.16$ & 6li.m & 11 & 139 & nा $-3 q_{4}$ & $F$ & & 1302 & \\
\hline 12 & 112 & 162 & $M$ & 30 & $\begin{array}{|ll|}1153 \\
\end{array}$ & 2 & 12 & 115 & \begin{tabular}{|l|}
169 \\
\end{tabular} & $F$ & & 1.111 & \\
\hline 13 & 121 & 1921 & $M$ & 28 & 1084 & 2 & 13 & 120 & 189 & $F$ & & 1094 & \\
\hline 14 & 124 & 217 & $F$ & 32 & 1138 & 2 & 14 & 132 & 25.4 & $F$ & & 1104 & \\
\hline 15 & 134 & 254 & $M$ & 30 & 1056 & 2 & 15 & 146 & $\begin{array}{lll}36 & 3 & \end{array}$ & & & 1.166 & \\
\hline Ave & 127 & 236 & & 33 & \begin{tabular}{lll|} 
& 13 & 31 \\
\end{tabular} & & Ave & 123 & $22-31$ & & & 1.153 & \\
\hline $\mathrm{SO}$ & 11 & 67 & & 5 & $\begin{array}{llll}0 & 0 & 52\end{array}$ & & SO & 13 & 7 & & & 0068 & \\
\hline SF & 31 & $\begin{array}{ll}1 & 71 \\
\end{array}$ & & 1 & $\begin{array}{lllll}0 & 0 & 1 & 4\end{array}$ & & $\Phi$ & 3 & 18 & & & $\begin{array}{llll}0 & 0 & 18 \\
\end{array}$ & \\
\hline
\end{tabular}




\begin{tabular}{|c|c|c|c|c|c|c|c|c|c|c|c|c|c|}
\hline FIsh & $F L(\mathrm{~mm}$ & WI (g) & Sex & Het & Cond & Other & Fish & $(\mathrm{mm})$ & (g) & Sex & HCt & Cond & Other \\
\hline $3 / 16 / 89$ & Group I & Awy 14 & 1145 & $5 \mathrm{am}$ & temp $=$ & & $3 / 16 / 89$ & Group II & Rwy 14: & temp & & & subgrp \\
\hline 1 & 120 & 202 & \begin{tabular}{|l|l|}
$F$ \\
\end{tabular} & & $\begin{array}{|ll|}1 & 169 \\
\end{array}$ & & 1 & 120 & $\begin{array}{l}18.7 \\
\end{array}$ & $F$ & 10 & 1082 & $T, 1$ \\
\hline 2 & 122 & 212 & $F$ & & 1.167 & $T, B$ & 2 & 127 & 237 & $\mathrm{M}$ & 30 & 1.157 & $T, 8,1$ \\
\hline 3 & 112 & 15 & $\mathbf{F}$ & & 1068 & An & 3 & 123 & 211 & $M$ & 38 & 1.134 & $T, B, 1$ \\
\hline 4 & 120 & 183 & $F$ & & 1059 & T,B & At & 118 & 17.1 & $F$ & 26 & 1041 & TB.LP. \\
\hline 5 & 121 & 202 & $M$ & & 1.14 & IB & 5 & 135 & 274 & $\mathbf{F}$ & 33 & 1.114 & $\mathrm{~TB}:$ \\
\hline 6 & 118 & 17.6 & $F$ & & 1.071 & $\mathrm{Lm}$ & 6 & 129 & 24.8 & $F$ & 37 & 1.155 & $T .8$. \\
\hline 7 & 115 & 169 & $M$ & & 1111 & T. B & 7 & 120 & 189 & $F$ & 19 & 1094 & $T, B, 1$ \\
\hline 8 & 125 & 222 & $M$ & & 1.137 & $\mathrm{~T}, \mathrm{~B}$ & 8 & 120 & 189 & $F$ & 43 & 1.094 & $T, B, 1$ \\
\hline 9 & 120 & 19.7 & $\mathrm{Md}$ & & 114 & $\mathrm{~T}, \mathrm{Lm}$ & 9 & 146 & 378 & $\mathrm{Md}$ & 41 & 1215 & 1 \\
\hline 10 & 123 & 203 & $\mathbf{M}$ & & $\begin{array}{lll}1 & 091 \\
\end{array}$ & $I$ & 10 & 125 & 21.5 & $M$ & 19 & 1101 & 2 \\
\hline 11 & 123 & 21.2 & $\sqrt{\mathbf{F}}$ & & 1.139 & T,B,An & 11 & 123 & 20.9 & $M$ & 15 & 1123 & 2 \\
\hline 12 & 135 & 27.5 & $\mathbf{M}$ & & 1118 & & 12 & 129 & 241 & $M$ & 28 & 1123 & 2 \\
\hline 13 & 136 & 28 & $F$ & & 1.113 & & 13 & 133 & 269 & $M$ & 20 & 1.143 & 2 \\
\hline 14 & 129 & 262 & $\mathbf{M}$ & & 122 & T.B & 14 & 131 & 249 & Md & 24 & 1108 & $B, 2$ \\
\hline 15 & 137 & 28.1 & F & & 1093 & $\mathrm{~T}$ & 15 & 160 & 502 & Md & 29 & 1223 & $B, 2$ \\
\hline Ave & 124 & 215 & & & 1.122 & & Ave. & 129 & 251 & & 27 & 1.127 & \\
\hline SO & 7 & 42 & & & $\begin{array}{llll}0 & 0 & 44\end{array}$ & & $S D$ & 11 & 86 & & 10 & 0048 & \\
\hline $\mathbb{E}$ & 2 & 1.1 & & & 0.011 & & $\mathbf{E}$ & 3 & 2.2 & & 3 & 0.012 & \\
\hline Fish \# & $F L \quad(\mathrm{~mm}$ & wi (g) & Sex & HCt & Cond & Other & Fish & $F L \quad(\mathrm{~mm})$ & $\left|w_{1} \quad(g)\right|$ & sex & HCt & Cond & Other \\
\hline $3 / 16 / 89$ & Group III & \begin{tabular}{|ll} 
Awy & 14 \\
\end{tabular} & temp & & & & $3 / 27 / 89$ & Group 1 & Awy 11 & 420 & $\mathrm{pm}, \mathrm{t}$ & $\operatorname{temp}=$ & \\
\hline 1 & 140 & 299 & Md & & 109 & $T, B$ & 1 & 110 & 14 & $M$ & & 1.052 & \\
\hline 2 & 128 & 229 & $M$ & & 1092 & & 2 & 130 & 244 & $F$ & & 1111 & \\
\hline 3 & 112 & 15 & $M$ & & 1068 & $T, B$ & 3 & 112 & 167 & Md & & 1.189 & \\
\hline 4 & 124 & 217 & $F$ & & 1138 & & 4 & 116 & 181 & $M$ & & 1.16 & $A n$ \\
\hline 5 & 131 & 269 & $F$ & & 1197 & TB & 5 & 123 & 223 & Md & & 1198 & \\
\hline 6 & 135 & 27.5 & $F$ & & 1118 & T.B & 6 & 122 & 212 & $M$ & & 1167 & \\
\hline 7 & 115 & 178 & Md & & 117 & & 7 & 123 & 20 & $F$ & & 1075 & \\
\hline 8 & 105 & 126 & $\bar{M}$ & & 1.088 & $\overline{\mathrm{T}} . \mathrm{B}$ & 8 & 122 & 207 & $\mathrm{~F}$ & & 1.141 & \\
\hline 9 & 117 & 18.3 & $\mathrm{Md}$ & & -1.143 & T. B.Lr & & -124 & & $F_{-}$ & & & \\
\hline 10 & 131 & 265 & $M$ & & 1.179 & $i B$ & 10 & 30 & 224 & $M$ & & 102 & \\
\hline 11 & 121 & 20.1 & $F$ & & $1 \quad 13511$ & T.B & 11 & 127 & $2: 3.7$ & $\bar{M}$ & & 1.157 & \\
\hline 12 & 119 & 193 & $F$ & & 1.145 & $T$ & 12 & 131 & 261 & $F$ & & 1161 & \\
\hline 13 & 121 & 194 & Md & & 1095 & T. $B$ & 13 & 134 & 298 & Md & & 1.239 & \\
\hline 14 & 134 & 293 & $\mathrm{Md}$ & & 1219 & 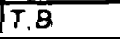 & 14 & .37 & 279 & Md & & 1.085 & \\
\hline 15 & 166 & $52 \overline{9}$ & $\vec{F}$ & & +156 & IT B & & & & Mol & & & \\
\hline Ave & 127 & 24 & & & 1135 & & Ave. & $\begin{array}{r}-145 \\
\end{array}$ & 221 & & & 1.134 & \\
\hline SO & 14 & 95 & & & 00044 & & 50 & 9 & 49 & & & 0.059 & \\
\hline SE & 4 & 25 & & & 0011 & & $S E$ & 2 & 13 & & & 0.015 & \\
\hline Fish & $F L \quad(\mathrm{~mm}$ & $\begin{array}{ll}w_{t} & (g) \\
\end{array}$ & Sex & Hct & Cond & Other & Fish & $F L \quad(m m)$ & Wt (g) & $\operatorname{sex}$ & Hct & Cond & Other \\
\hline $3: 27189$ & Group II & Rwy 11 & & & & & 3127189 & Group III & Rwy 11 & & & & \\
\hline 1 & 123 & $21^{\circ} 4$ & $M$ & 13 & 115 & & 1 & 120 & 203 & $F$ & & 1175 & SAn \\
\hline 21 & 134 & 269 & $M$ & 32 & 1.118 & & 2 & 131 & 242 & $F$ & & 1.076 & \\
\hline 3 & 120 & 183 & $F$ & 34 & 1059 & & 3 & 138 & 286 & Md & & 1088 & \\
\hline 4 & 120 & 193 & Md & 30 & 1.117 & & 4 & 149 & 39.3 & Ad & & 1188 & \\
\hline 5 & 105 & $13 \ldots 3$ & $F$ & 30 & 1.149 & & 5 & 150 & 38.3 & Md & & 1.135 & \\
\hline 61 & 1241 & 21.1 & $F$ & 34 & 1.107 & & 6 & 123 & 191 & $M$ & & 1.026 & \\
\hline 7 & 131 & 244 & $\mathrm{MU}$ & & 1085 & & 7 & 124 & 22 & $F$ & & 1154 & \\
\hline 8 & 140 & 30.2 & $\overline{M d}$ & 36 & 1.101 & & 8 & 125 & 23 & Md & & 1178 & \\
\hline 9 & 135 & 284 & $\mathbf{F}$ & 32 & 1154 & & 9 & 109 & 153 & $M$ & & 1.181 & \\
\hline 10 & 133 & 255 & $F$ & 35 & 1084 & & 10 & 115 & 16.3 & $F$ & & 1072 & An \\
\hline 11 & 116 & 177 & $M$ & 29 & 1134 & & 11 & 119 & 193 & $F$ & & 1.145 & \\
\hline 12 & 123 & \begin{tabular}{ll|l}
20 & $8 / F$ \\
\end{tabular} & & 39 & 1118 & & 12 & 113 & $15 ?$ & $M$ & & 1.102 & \\
\hline 13 & 124 & 213 & $F$ & 35 & 1117 & & 13 & 113 & 165 & $M$ & & 1.145 & \\
\hline 14 & 127 & 237 & $M$ & 35 & 1157 & & 14 & 135 & 263 & $M$ & & 1069 & \\
\hline 15 & 204 & 97 & Nd & 40 & 1143 & & 15 & 152 & 37 & $\mathrm{Md}$ & & 1.054 & \\
\hline Ave & 131 & $\begin{array}{lll}27 & 3\end{array}$ & & 32 & 1119 & & \begin{tabular}{|l} 
Ave. \\
\end{tabular} & 128 & \begin{tabular}{ll|}
241 \\
\end{tabular} & & & 1.119 & \\
\hline 尧 & & & & & & & & & & & & & \\
\hline $\mathbf{S E}$ & 226 & 19518 & & 62 & 00290007 & & $S E$ & 144 & 8321 & & & 0.0530014 & \\
\hline
\end{tabular}




\begin{tabular}{|c|c|c|c|c|c|c|c|c|c|c|c|c|c|}
\hline Fish & $F L \quad(m m$ & Wt $(9)$ & Sex & Het & Cond & Other & Fish & FL $(\mathrm{mm})$ & Wi $(g)$ & Sex & Hct & Cond & Oiher \\
\hline $3 / 27 / 89$ & Group IV & Rwy 11 & & & & & $3 / 27 / 89$ & Group I & Rwy 12 & & & & \\
\hline 1 & 120 & \begin{tabular}{r|}
154 \\
\end{tabular} & $M$ & & 0891 & deed & \begin{tabular}{|r|}
1 \\
\end{tabular} & 117 & 182 & $\mathbf{F}$ & & 1.136 & \\
\hline 2 & 113 & 146 & Md & & 1012 & moribund & 2 & 113 & 153 & $F$ & & $\begin{array}{ll}106 \\
\end{array}$ & \\
\hline 3 & 115 & 151 & $F$ & & 1028 & moribund & 3 & 117 & 171 & $M$ & & 1068 & \\
\hline 4 & 107 & 125 & $M$ & & 102 & moribund & 4 & 113 & 171 & $F$ & & 1.185 & \\
\hline 5 & 103 & 10.6 & $M$ & & O 97 & & 5 & 116 & $\begin{array}{lll}17 & 3\end{array}$ & $F$ & & 1.108 & \\
\hline 6 & 111 & 138 & $F$ & & 1009 & & 6 & 125 & 234 & Md & & 1.198 & \\
\hline 7 & 129 & 22 & $F$ & & 1025 & & 7 & 123 & 21.8 & $F$ & & 1.171 & \\
\hline 8 & 120 & 17.1 & $F$ & & 099 & & 8 & 121 & 20.7 & $F$ & & 1.168 & \\
\hline 9 & 112 & 138 & $\mathbf{F}$ & & $\begin{array}{lll} & 982 \\
\end{array}$ & & 9 & 127 & 244 & $F$ & & 1.194 & \\
\hline 10 & 122 & 192 & $\mathbf{F}$ & & 1057 & & 10 & 130 & 252 & $\bar{M}$ & & $\begin{array}{lll}1 & 147 \\
\end{array}$ & \\
\hline 11 & 118 & 17 & $M$ & & 1035 & & 11 & 128 & 236 & $M$ & & 1125 & \\
\hline 12 & 133 & 241 & $M$ & & 1024 & & 12 & 125 & 21 & $M$ & & 1075 & \\
\hline 13 & 120 & 174 & $\mathbf{F}$ & & 1007 & & 13 & 130 & 239 & Md & & 1088 & $A n$ \\
\hline 14 & 105 & 117 & $M$ & & 1011 & & 14 & 138 & 299 & $M$ & & 1138 & \\
\hline 15 & 119 & 172 & $M$ & & 1021 & & 15 & 168 & 519 & Md & & 1095 & \\
\hline 16 & 119 & 16.1 & Md & & 0955 & & Ave. & 126 & 234 & & & $\begin{array}{|ll|}1 & 13 \\
\end{array}$ & \\
\hline 17 & 120 & 171 & $M$ & & 099 & & SO & 14 & 88 & & & 0046 & \\
\hline 18 & 132 & 23 & $F$ & & 1 & & $\overline{\mathbf{E}}$ & 4 & 23 & & & 0.012 & \\
\hline 19) & 136 & 26 & $M$ & & 1034 & & & & & & & & \\
\hline $201^{1}$ & 148 & $37 \quad 1$ & $\sqrt{M}$ & & $1 \quad 144$ & & & & & & & & \\
\hline Ave & 120 & 18 & & & 1.01 & & & & & & & & \\
\hline SO & 11 & 61 & & & 0048 & & & & & & & & \\
\hline SE & 2 & \begin{tabular}{l|}
14 \\
\end{tabular} & & & 0011 & & & & & & & & \\
\hline Fish & $\mathrm{FL} \quad(\mathrm{mm}$ & Wt $(g)$ & sex & Hct & $\begin{array}{ll}\text { Cond } \\
\end{array}$ & Other & Fish & $\mathrm{FL}(\mathrm{mm})$ & wi (a) & sex & $\mathrm{HCl}$ & Cond & Other \\
\hline $327: 89$ & Group II & Rwy 12 & & & & & $3.27 \cdot 89$ & Group III & Rwy 12 & & & & \\
\hline 1 & \begin{tabular}{|r|}
117 \\
\end{tabular} & 154 & $\mathbf{F}$ & 29 & 0962 & & 1 & 122 & 195 & $M$ & & 1074 & \\
\hline 21 & 128 & 214 & $\begin{array}{l}4 M \\
\end{array}$ & 30 & 102 & & 21 & $13: 3$ & 268 & $\mathbf{F}$ & & 1139 & \\
\hline 3 & 120 & 19.8 & $F$ & 21 & $\begin{array}{lll}14 & 146 \\
\end{array}$ & & 3 & 127 & 234 & $F$ & & 1142 & \\
\hline 4 & 119 & 193 & $F$ & 15 & 1145 & & 4 & 133 & 267 & $M d$ & & 1135 & \\
\hline 5 & 123 & 21.7 & $\mathbf{F}$ & 29 & 1166 & & 5 & 163 & \begin{tabular}{ll|}
484 \\
\end{tabular} & Md & & 1118 & $A_{n}$ \\
\hline 6 & 137 & 302 & Md & 37 & 1174 & & 6 & 128 & 225 & $\mathrm{~F}$ & & 1073 & \\
\hline 7 & 124 & 213 & $F$ & 30 & 1117 & & 7 & 105 & $12 \mathrm{~g}$ & $\bar{M}$ & & 1114 & \\
\hline 8 & 128 & 22.4 & $F$ & 36 & 1068 & & 8 & 140 & $\begin{array}{lll}31 & 3 \\
\end{array}$ & Md & & 1141 & \\
\hline 9 & 125 & 23 & $M$ & 28 & 1178 & & 9 & 124 & 218 & $M$ & & 1143 & \\
\hline 10 & 141 & $\begin{array}{lll}33 & 3 \\
\end{array}$ & Md & 18 & 1188 & & 10 & 119 & 21 & $F$ & & 1246 & \\
\hline 11 & 121 & 181 & $F$ & 35 & 1022 & & 11 & 125 & 216 & $F$ & & 1.106 & \\
\hline 12 & 128 & 206 & $M$ & 7 & $\begin{array}{ll}0 & 982 \\
\end{array}$ & & 12 & 115 & 167 & $\mathbf{F}$ & & 1098 & \\
\hline 13 & 126 & 215 & $F$ & 35 & 1075 & & 13 & 140 & 291 & $\mathbf{F}$ & & 106 & \\
\hline 14 & 143 & 337 & $F$ & 13 & 1152 & & 14 & 132 & 259 & $\mathbf{M}$ & & 1126 & \\
\hline 15 & 184 & 673 & $\mathbf{F}$ & 20 & 108 & & 15 & 146 & 368 & $\mathbf{F}$ & & 1182 & \\
\hline Ave & 131 & 259 & & 26 & 1098 & & Ave & 130 & 256 & & & 1127 & \\
\hline $\mathrm{SO}$ & 17 & 126 & & 9 & $\begin{array}{llll}0 & 0 & 75 \\
\end{array}$ & & SO & 14 & 86 & & & 0046 & \\
\hline SE & 4 & 33 & & 2 & 0019 & & SE & 4 & \begin{tabular}{|l|}
22 \\
\end{tabular} & & & 0.012 & \\
\hline Fish & $F L \quad 1 \mathrm{~mm}$ & Wt (g) & Sex & $\mathrm{HCl}$ & Cond & Other & Fish & $(m \mathrm{~m})$ & Wt (g) & $\operatorname{sex}$ & HCt & Cond & Other \\
\hline $\begin{array}{lll}32 & 27\end{array}$ & Group IV & Rwy 12 & & & & & 3.28 .89 & Group 1 & \begin{tabular}{|l|l} 
Pwy & 13 \\
\end{tabular} & 820 & $\mathrm{am}$ & & \\
\hline 1 & 122 & 176 & $\mathrm{M}$ & & $\begin{array}{lll}0 & 969\end{array}$ & & 1 & 100 & \begin{tabular}{|l|l|}
11 & 3 \\
\end{tabular} & $\mathbf{F}$ & & 113 & \\
\hline 2 & 168 & 498 & $F$ & & 105 & $A_{n}$ & 2 & 116 & \begin{tabular}{ll|l}
183 & 1
\end{tabular} & $M$ & & 1172 & \\
\hline 3 & 130 & 226 & $\mathbf{F}$ & & 1029 & & 3 & 111 & 151 & $F$ & & 1104 & \\
\hline 4 & 116 & 141 & $F$ & & $\begin{array}{llll}0 & 9 & 03 \\
\end{array}$ & & 4) & 102 & 108 & $M$ & & 1018 & \\
\hline 5 & 121 & 17.5 & $\mathbf{M}$ & & 0988 & & 5 & 115 & 168 & $F$ & & 1105 & \\
\hline 6. & 134 & 224 & $M$ & & $\begin{array}{ll}0 & 931\end{array}$ & & 6 & 128 & 241 & $F$ & & 1144 & \\
\hline 7 & 132 & $2 i 1$ & 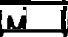 & & 1004 & & 7 & 114 & 156 & add & & 1053 & \\
\hline 8 & 118 & 165 & $M$ & & 1004 & & 8 & 122 & $19 \mathrm{~g}$ & $M$ & & 1096 & \\
\hline 9 & 134 & 233 & Md & & 0968 & & a & 131-1 & 103 & $F$ & & 1117 & \\
\hline 10 & 135 & 268 & Md & & 1089 & $A_{n}$ & 10 & 122 & $201 \mathrm{~F}$ & $F$ & & 11011 & \\
\hline 111 & $1331^{\circ}$ & 2251 & $M$ & & 0956 & $A_{n}$ & 11 & 120 & 1951 & II & & $\begin{array}{|ll|}1 & 128\end{array}$ & \\
\hline 121 & 1451 & 326 & $\mathbf{F}$ & & 1069 & & 12 & 125 & 219 & $M$ & & 11211 & \\
\hline 131 & 140 & ${ }^{-2 y} \hat{9} \mid i$ & ii & & 109 & $\overline{A n}$ & 13 & 128 & $24 \quad 6 F$ & $\mathrm{~F}$ & & 1173 & \\
\hline 14 & 165 & 464 & $F$ & & 1033 & & 14 & $13 \mathrm{C}$ & 243 & $M$ & & 1106 & \\
\hline 15 & 111 & 156 & $F$ & & $1+41$ & Doad & 15 & 133 & $22+5 A$ & $M$ & & 1041 & \\
\hline 16 & 112 & 15 & $M$ & & 1068 & Dead & Ave & 119 & 191 & & & 1107 & \\
\hline 17 & 106 & 116 & $\mathbf{F}$ & & 0974 & Dand & 50 & 10 & 45 & & & 0044 & \\
\hline 18 & 115 & 157 & $M$ & & 1032 & Deed & SE & 2 & $\begin{array}{ll}12 \\
\end{array}$ & & & 0011 & \\
\hline 19 & 114 & 155 & $\mathbf{F}$ & & 1046 & Doed & & & & & & & \\
\hline 20 & 123 & 186 & $\mathbf{F}$ & & 1 & & & & & & & & \\
\hline Ave & 129 & 229 & & & 1017 & & & & & & & & \\
\hline$\$ 0$ & 17 & 102 & & & 0059 & & & & & & & & \\
\hline SE & \begin{tabular}{l|l}
4 \\
\end{tabular} & $\begin{array}{ll}2 & 3 \\
\end{array}$ & & & $\begin{array}{lllll}0 & 0 & 15 \\
\end{array}$ & & & & & & & & \\
\hline
\end{tabular}




\begin{tabular}{|c|c|c|c|c|c|c|c|c|c|c|c|c|c|}
\hline Fish & $\mathrm{FL} \quad(\mathrm{mm}$ & Wt (g) & Sex & HCl & Cond & Other & Fish & FL $(\mathrm{mm})$ & Wt $(g)$ & $\operatorname{Sex}$ & $\mathrm{HCt}$ & Cond & Other \\
\hline 328.89 & Group II & Rwy 13 & & & & & $3 / 28 / 89$ & Group III & Rwy 13 & & & & \\
\hline 1 & \begin{tabular}{|r|}
133 \\
\end{tabular} & 248 & & 32 & 1054 & & 1 & 125 & 201 & $\mathrm{~F}$ & & 1029 & \\
\hline 2 & 121 & 197 & & 28 & 1112 & & 2 & 124 & 208 & $M$ & & 1091 & \\
\hline 3 & 120 & 204 & & 26 & 1181 & & 3 & 118 & $\begin{array}{lll}182 \\
\end{array}$ & $F$ & & 1108 & \\
\hline 4 & 145 & 355 & & 35 & \begin{tabular}{lll|}
1 & 14 & \\
\end{tabular} & & 4 & 121 & 203 & $F$ & & $\begin{array}{ll}146 \\
\end{array}$ & \\
\hline 5 & 137 & 3221 & & 32 & 1248 & & 5 & 115 & 172 & $M$ & & 1331 & \\
\hline 6 & 117 & 182 & & 30 & 1136 & & 6 & 133 & 247 & $F$ & & 105 & \\
\hline 7 & 143 & 32 & & 30 & 1094 & & 7 & 119 & 189 & $F$ & & 1122 & \\
\hline 8 & 151 & $\begin{array}{ll}382 \\
\end{array}$ & & 34 & $\begin{array}{lll}1 & 1 & 1\end{array}$ & & 8 & 158 & 446 & Md & & $1 \quad 131$ & \\
\hline 9 & 148 & 359 & & 35 & 1107 & & 9 & 121 & 191 & $M$ & & 1078 & \\
\hline 10 & 135 & 317 & & 35 & 1288 & & 10 & 125 & 202 & $\mathrm{~F}$ & & $\begin{array}{lll}1 & 034 \\
\end{array}$ & \\
\hline 111 & 154 & 402 & & 341 & 1101 & & 11 & 111 & 152 & $F$ & & \begin{tabular}{|llll}
1 & 1 & 1 & 1 \\
\end{tabular} & \\
\hline 12 & 147 & 377 & & 331 & $|187|$ & & 121 & 1251 & 221 & $F$ & & $\begin{array}{|ll|}1 & 126 \\
\end{array}$ & \\
\hline 131 & 157 & 5 & & & 1 & & 1 & & & & & \begin{tabular}{ll|}
1 & $\mathbf{1 2 6}$ \\
\end{tabular} & \\
\hline 14 & $1521=1$ & $39 \_03.71$ & & 36 & \begin{tabular}{|lll}
1 & 13
\end{tabular} & & 1.4 & 125 & $22|5|$ & $M$ & & $\begin{array}{lll}1 & 098 \\
\end{array}$ & \\
\hline 15 & 189 & $09+3$ & & 350 & 14204 & & 15 & 169 & $u \in 2$ & Md & & $\begin{array}{ll}1 & 164 \\
\end{array}$ & \\
\hline $\mathrm{SO}$ ! & 14.31 & $95 \mathrm{RI}$ & & $3-31$ & 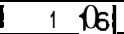 & & Ave & 1281 & 241 & & & \begin{tabular}{ll|}
1 & 103 \\
\end{tabular} & \\
\hline & 18 & 3 & & $3 \mid$ & 073 & & $S D$ & 161 & $\begin{array}{ll}11 & 1\end{array}$ & $T$ & & $\begin{array}{lll}0 & 04\end{array}$ & \\
\hline$\cong$ & 5 & 4) & & 1 & 0019 & & SE & 4 & 791 & 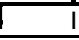 & 1 & 0011 & \\
\hline Fish & FL $\quad(\mathrm{mm}$ & $W I(g) \$$ & pex & $\mathrm{Hct}$ & fond & Other & $\mathrm{Fish} *$ & $F L \quad(m m)$ & $w t \quad(g)$ & $\sqrt{\operatorname{sex} x}$ & $\mid \mathrm{HCl}$ & ICond & Other \\
\hline $3,28,89$ & Group IV & Rwy 13 & & & & & $3 / 28: 89$ & Group I & Rwy 14 & 1040 & $0 \mathrm{am}$ & temp $=$ & \\
\hline 1 & 117 & 162 & $M$ & & 1011 & & \begin{tabular}{r|}
1 \\
\end{tabular} & \begin{tabular}{|r|}
115 \\
\end{tabular} & $\begin{array}{ll}156 \\
\end{array}$ & $6 \mid \mathrm{F}$ & & 1026 & T B \\
\hline & & & & & & & & & & & & & \\
\hline 3 & 135 & $25 \leqslant$ & IF & & 10n?al & An & al & 121 & $18 \mathrm{G}$ & {$[F$} & & 1093 & $T, B$ \\
\hline 4 & 122 & 188 & $F$ & & 1035 & & 4 & 116 & 165 & $M$ & & 1057 & $\mathrm{~TB}$ \\
\hline 5 & 120 & 171 & $M$ & & 0991 & & 51 & 1181 & $\begin{array}{ll}16 \quad 4 \\
\end{array}$ & $M$ & & $\begin{array}{lll}0 & 998 \\
\end{array}$ & B B \\
\hline 6 & 129 & 232 & $F$ & & 1081 & & 6 & 123 & 19 & $M$ & & $\begin{array}{|ll|}1 & 021 \\
\end{array}$ & $|A|$ \\
\hline 7 & $15 \mathrm{C}$ & 334 & $F$ & & $\begin{array}{ll}0 & 99 \\
\end{array}$ & & 7 & 130 & 01215 & $F$ & & $\begin{array}{ll}0 & 979 \\
\end{array}$ & \\
\hline 8 & 127 & 206 & $M$ & & 1006 & & 8 & 131 & $\begin{array}{|lll|}2 & 5 & .2 \\
\end{array}$ & $\bar{M}$ & & 1121 & \\
\hline 9 & 127 & 202 & $F$ & & 0986 & & 9 & 124 & 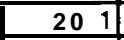 & $M$ & & 1.054 & $T . B$ \\
\hline 10 & 119 & 185 & $F$ & & \begin{tabular}{|l|}
098 \\
\end{tabular} & & 10 & 118 & 194 & $F$ & & 1181 & $T, B$ \\
\hline 11 & 145 & $\begin{array}{llll}3 & 3 & 1 \\
\end{array}$ & $M$ & & 1086 & & 11. & 125 & 21. 9 & $F$ & & 1.121 & T $B$ \\
\hline 12 & 121 & 168 & $M$ & & 0948 & & 12 & 129 & 244 & $M$ & & 1.137 & \\
\hline 13 & 119 & 174 & $F$ & & 1033 & & 13 & 135 & 248 & $F$ & & 1008 & $\mathrm{~T} \mathrm{~B}$ \\
\hline 14 & 122 & 207 & $M$ & & $\begin{array}{|lll|}1 & 1 & 4\end{array}$ & & 14 & 144 & $\begin{array}{lll}33 & 3 \\
\end{array}$ & $M$ & & 4115 & $\mathrm{~T} . \mathrm{B} \mathrm{Lm}$ \\
\hline 15 & 133 & 248 & $F$ & & 1054 & & 15 & 165 & 523 & $M d$ & & 1164 & \\
\hline 16 & 131 & 243 & $\mathrm{Md}$ & & 1081 & & Ave & 127 & 228 & & & 1075 & \\
\hline 17 & 125 & 20 & $F$ & & 1024 & & SO & 14 & 96 & & & 0063 & \\
\hline 18 & 137 & 272 & Md & & 1058 & & SE & 4 & 25 & & & 0016 & \\
\hline 19 & 124 & 18 & $M$ & & 0944 & & & & & & & & \\
\hline 20 & 114 & 152 & $F$ & & 1026 & Doad & & & & & & & \\
\hline Ave & 127 & 215 & & & $\begin{array}{ll}1 & 0 \\
\end{array}$ & & & & & & & & \\
\hline $\mathrm{SD}$ & 9 & 52 & & & 0051 & & & & & & & & \\
\hline SE & 2 & $\begin{array}{ll}12 \\
\end{array}$ & & & 0011 & & & & & & & & \\
\hline Fish & $\mathrm{FL} \quad(\mathrm{mm}$ & WI $(g)$ & Sex & $\mathrm{HCt}$ & \begin{tabular}{|l|} 
Cond \\
\end{tabular} & Other & Fish & FL $\quad(\mathrm{mm})$ & \begin{tabular}{|ll}
$W_{1}$ & $(g)$
\end{tabular} \mid & Sex & Hct & Cond & Other \\
\hline 3.28 .89 & Group II & Rwy 14 & & & & & 3128189 & Group III & $\begin{array}{|ll|}\text { Awy } & 14 \\
\end{array}$ & & & & \\
\hline 1 & $\begin{array}{r}122 \\
\end{array}$ & 20 & & 26 & 1101 & $T, B$ & 1 & 115 & 165 & $M$ & & 1.085 & An \\
\hline 2 & 125 & 209 & & 21 & $\begin{array}{ll}1 & 07 \\
\end{array}$ & & 2 & 119 & 174 & $F$ & & 1.033 & An \\
\hline 3 & 139 & 2911 & & 36 & 1084 & $T$ & 3 & 133 & 258 & $M$ & & 1097 & $T, B$ \\
\hline 4 & 130 & 241 & & 32 & 1097 & T B & 4 & 139 & 307 & $F$ & & 1143 & \\
\hline 5 & 175 & 204 & & 32 & 1044 & TB & 5 & 126 & 234 & $F$ & & 1.17 & T, B \\
\hline 6 & 133 & 233 & & 38 & 099 & & 6 & 126 & 207 & $M$ & & 1035 & $T$ \\
\hline 7 & 123 & 20 & & 27 & 1075 & $T, B$ & 7 & 139 & 298 & $M$ & & $\begin{array}{lll}1 & 11\end{array}$ & \\
\hline 8 & 135 & 267 & & 23 & 1085 & $T, B$ & 8 & 127 & 222 & Md & & 10841 & $1 \mathrm{~T} . \mathrm{B}$ \\
\hline 9 & 135 & 269 & & 21 & \begin{tabular}{ll|}
1 & 093 \\
\end{tabular} & $T, B$ & 9 & 127 & 219 & $F$ & & $\begin{array}{lll}1 & 069 \\
\end{array}$ & $T, B$ \\
\hline 10 & 135 & 279 & & 39 & $\begin{array}{|ll|}1 & 134 \\
\end{array}$ & $\mathrm{~T}, \mathrm{~B}$ & 10 & 146 & $\begin{array}{ll}2 & 3 \\
\end{array}$ & $M$ & & 1.038 & T,B.An \\
\hline 11 & 130 & $\begin{array}{ll}22 & 9 \\
\end{array}$ & & 27 & $\begin{array}{llll}1 & 0 & 42 \\
\end{array}$ & & 11 & 131 & 25.1 & $F$ & & 1.117 & \\
\hline 12 & 122 & 208 & & 24 & 1145 & $T, B$ & 12 & 120 & 189 & $M$ & & 1.094 & $T, B$ \\
\hline 13 & 122 & 206 & & 36 & $\begin{array}{lll}1 & 134 \\
\end{array}$ & & 13 & 134 & 26 & $F$ & & 10811 & \\
\hline 14 & 121| & 196 & & 21 & 1106 & $\mathrm{~T}$ & 14 & 135 & 266 & $F$ & & 1081 & \\
\hline 15 & 147 & 38 & & 44 & $\begin{array}{lll}1 & 196 \\
\end{array}$ & & 15 & 135 & 278 & $F$ & & $\begin{array}{ll}113 \\
\end{array}$ & T.B.An \\
\hline Ave & 13c) & 2411 & & 29 & 1.093 & & Ave. & 130 & $\begin{array}{lll}24 & 3\end{array}$ & & & 1.091 & \\
\hline$S D$ & .8 & -5 & & 71 & $\begin{array}{llll}0 & 0 & 49\end{array}$ & & 50 & 6 & 48 & & & 0039 & \\
\hline SE & 21 & $\begin{array}{ll}1 & 3\end{array}$ & & 21 & $\begin{array}{lll}0 & 01: 3\end{array}$ & & $\mathbf{S E}$ & 21 & 12 & & & 001 & \\
\hline
\end{tabular}




\begin{tabular}{|c|c|c|c|c|c|c|c|c|c|c|c|c|c|}
\hline Fish \# & $(\mathrm{mm}$ & Wt (g) & Sex & $\mathrm{HCl}$ & Cond & Other & & & & & & & \\
\hline $3 / 28 / 89$ & Group IV & Rwy 14 & & & & & & & & & & & \\
\hline 1 & 125 & 214 & $F$ & & 1096 & $\mathrm{~T}, \mathbf{B} \mathrm{Lm}$ & & & & & & & \\
\hline 2 & 130 & 235 & $F$ & & 107 & $\mathrm{~T}, \mathrm{~B}$ & & & & & & & \\
\hline 3 & 128 & 219 & $F$ & & 1044 & T.B & & & & & & & \\
\hline 4 & 120 & 186 & $F$ & & 1076 & An & & & & & & & \\
\hline 5 & 127 & 211 & $F$ & & 103 & $T$ & & & & & & & \\
\hline 6 & 117 & 165 & $F$ & & 103 & $T, B, A n$ & & & & & & & \\
\hline 7 & 136 & 25 & $M$ & & 0994 & T, B Lm & & & & & & & \\
\hline 8 & 132 & 263 & $M$ & & 1.143 & $\mathrm{~T}$ & & & & & & & \\
\hline 9 & 136 & 25 & Md & & 0994 & & & & & & & & \\
\hline 10 & 116 & 156 & $F$ & & 0999 & $\mathrm{~T}, \mathrm{~B}$ & & & & & & & \\
\hline 11 & 122 & 182 & $M$ & & 1002 & $\mathrm{~T}, \mathrm{~B}$ & & & & & & & \\
\hline 12 & 123 & 191 & $M$ & & 1.026 & $\mathrm{~T}$ & & & & & & & \\
\hline 13 & 118 & 153 & $F$ & & 0.931 & & & & & & & & \\
\hline 14 & 133 & 24 & $\mathbf{M}$ & & 102 & $T$ & & & & & & & \\
\hline 15 & 120 & 179 & $F$ & & 1036 & T, B & & & & & & & \\
\hline 16 & 131 & 234 & $F$ & & 1041 & & & & & & & & \\
\hline 17 & 123 & 189 & $F$ & & 1.016 & T.B & & & & & & & \\
\hline 18 & 125 & 217 & $F$ & & 1.111 & & & & & & & & \\
\hline 19 & 121 & 181 & $F$ & & 1022 & $\mathrm{~T}, \mathrm{~B}$ & & & & & & & \\
\hline 20 & 120 & 174 & $F$ & & 1007 & T,B, Dead & & & & & & & \\
\hline Ave & 125 & 204 & & & 1034 & & & & & & & & \\
\hline $\mathrm{SO}$ & 6 & 33 & & & 0047 & & & & & & & & \\
\hline$\Phi$ & 2 & 07 & & & 0011 & & & & & & & & \\
\hline
\end{tabular}




\begin{tabular}{|c|c|c|c|c|c|c|c|c|c|c|c|c|c|}
\hline \multicolumn{2}{|c|}{ Leavenworth } & \multicolumn{12}{|c|}{ Md=developing male; Mp=fully developed, precocious male; $A n=a n e m i c$} \\
\hline$L p=$ pale & liver; $\mathrm{Lm}=$ & $=$ mottled & live & $\overline{e r} \mathbf{T}_{\mathrm{i}}$ & $=$ coded & wire tog & $B=$ brand & ded 1 & & & & & \\
\hline Fish $:$ & $\mathrm{FL}(\mathrm{mm}$ & Wi (g) & Sex & $\mathrm{HCt}$ & \begin{tabular}{|l|l} 
Cond & 0 \\
\end{tabular} & Other & Fish $\mid F$ & FL $(\mathrm{mm}$ & Wt (g) & Sex & HCI & Cond & Other \\
\hline 37.89 & \begin{tabular}{|l|l|l|l|l} 
Group 1 & F \\
\end{tabular} & Rwy 49 & 130 & pm te & $\mathrm{emp}=2$ & & $3 \cdot 7: 89 \mathrm{G}$ & Group 11 F & Rwy 49 & & & & \\
\hline 1 & 136 & 264 & $M$ & & \begin{tabular}{ll|l}
105 & $N$ \\
\end{tabular} & Most & 1 & 149 & 326 & $M$ & 34 & 0986 & Most \\
\hline 2 & 120 & $17 \mathrm{gff}$ & $\bar{F}$ & & \begin{tabular}{ll|l}
$1036 / \mathrm{h}$ \\
\end{tabular} & had pale & 2 & 111 & 149 & $\mathbf{F}$ & 42 & 1089 & had \\
\hline 3 & 110 & 145 & $M$ & & 1089 & IIvers & 3 & 155 & 359 & Md & 36 & 0964 & pale \\
\hline 4 & 109 & 136 & $M$ & & 105 & & 4 & 136 & 242 & Md & 49 & 0962 & livers \\
\hline 5 & 110 & 139 & $\bar{M}$ & & $\begin{array}{lll} & 044 \\
\end{array}$ & & 5 & 128 & 237 & $\mathrm{~F}$ & 45 & \begin{tabular}{ll|}
1 & 13 \\
\end{tabular} & \\
\hline 6 & 111 & 1461 & $\mathbf{M}$ & & 1068 & & 6 & 112 & 14.5 & $M$ & & 1032 & \\
\hline 7 & 104 & 125 & $\mathbf{F}$ & & 1111 & & 7 & 127 & 2071 & $F$ & 40 & $\begin{array}{llll}1 & 0 & 1 & 1 \\
\end{array}$ & \\
\hline 8 & 117 & $\begin{array}{lll}17 & 3 \\
\end{array}$ & $F$ & & 108 & & 8 & 122 & 207 & Md & 41 & 1114 & \\
\hline 9 & 110 & 149 & $\bar{M}$ & & 1119 & & 9 & 115 & 174 & $M$ & 39 & 1144 & \\
\hline 10 & 127 & 2311 & $M p$ & & 1128 & & 10 & 119 & 185 & $F$ & 44 & 1098 & \\
\hline 11 & 130 & 232 & $F$ & & 1056 & & 11 & 112 & 1421 & $F$ & 41 & 10011 & \\
\hline 12 & 149 & 345 & Md & & $\begin{array}{llll} & 0 & 43 \\
\end{array}$ & & 12 & 117 & 1731 & $M$ & 42 & 100 & \\
\hline 13 & 123 & 204 & $\bar{M}$ & & 1096 & & 13 & 110 & $144 \mid$ & $F$ & 38 & 1082 & \\
\hline 14 & 142 & 324 & $F$ & & 1132 & & 14 & 113 & 157 & $M$ & 40 & 1088 & \\
\hline 15 & 157 & 365 & $\bar{F}$ & & 0 & & 15 & 110 & 145 & $M$ & 43 & 1089 & \\
\hline Ave & 124 & 211 & & & 107 & & Ave & 122 & 20 & & 41 & 106 & \\
\hline 50 & 16 & 81 & & & 0048 & & So & 14 & 67 & & 4 & 0062 & \\
\hline$\Phi$ & 4 & 21 & & & 0012 & & $\Phi$ & 4 & 17 & & 1 & $0 \begin{array}{llll}0 & 0 & 16 \\
\end{array}$ & \\
\hline Fish & $F L \quad(m \mathrm{~m}$ & Wt (g) & Sex & Hat & $\begin{array}{ll}\text { Cond } & \\
\end{array}$ & Other & Fish & FL $\quad(\mathrm{mm}$ & wi lat & $\operatorname{sex}$ & HCI & Cond & Other \\
\hline 3789 & Group III & Awy 49 & & & & & $3 / 141890$ & Group I & $1100 \mathrm{am}$ & lem & $p=45$ & Awy 45 & \\
\hline 1 & \begin{tabular}{|l|}
24 \\
\end{tabular} & 218 & $M$ & & 11431 & Most & \begin{tabular}{|r|}
1 \\
\end{tabular} & 107 & 132 & $M$ & & 1078 & \\
\hline 2 & 132 & $\begin{array}{|lll|}2 & 4 & 1\end{array}$ & $F$ & & $1048 \mathrm{n}$ & had pale & 2 & 112 & 142 & $M$ & & 1011 & \\
\hline 3 & 151 & 403 & $\bar{F}$ & & \begin{tabular}{lll|l}
1 & 1791 \\
\end{tabular} & Iivers & 3 & 123 & 198 & $M$ & & 1064 & \\
\hline 4 & 115 & 154 & $F$ & & 10013 & & 4 & 115 & 163 & $M$ & & 1072 & \\
\hline 5 & 124 & 206 & $F$ & & 108 & & 5 & 108 & $\begin{array}{lll}33 \\
\end{array}$ & $M$ & & $i 050$ & \\
\hline 6 & 113 & 16 & $F$ & & 1109 & & 6 & 112 & 156 & $M$ & & $\begin{array}{lll} & 1 & 1\end{array}$ & \\
\hline 7 & 140 & 296 & Mad & & 1079 & & 7 & 105 & 119 & $M$ & & 1028 & \\
\hline 8 & 111 & 16 & $M$ & & $\begin{array}{ll}117 \\
\end{array}$ & & 8 & 115 & 169 & $\mathbf{F}$ & & $\begin{array}{llll} & 1 & 1 & 1 \\
\end{array}$ & \\
\hline 9 & 141 & 246 & $F$ & & 0878 & & $\mathrm{~g}$ & 106 & 127 & $\mathbf{F}$ & & 1066 & \\
\hline 10 & 129 & 231 & $M$ & & 1076 & & 10 & 112 & 154 & $\mathbf{F}$ & & 1096 & \\
\hline 11 & 110 & 14 & $F$ & & $\begin{array}{lll}1 & 052 \\
\end{array}$ & & 11 & 103 & 118 & $F$ & & 108 & \\
\hline 12 & 149 & 354 & $M$ & & 107 & & 12 & 110 & 147 & $\mathbf{F}$ & & 1104 & \\
\hline 13 & 108 & 133 & $M$ & & 1056 & & 13 & 122 & 204 & $M$ & & 1123 & \\
\hline 14 & 113 & 158 & $M$ & & 1095 & & 14 & 135 & 253 & $M$ & & 1028 & \\
\hline 15 & 134 & 261 & $\mathbf{F}$ & & 1085 & & 15 & 128 & 251 & $M$ & & 1197 & \\
\hline Ave & 126 & 224 & & & 1075 & & Ave & 114 & 164 & & & 1082 & \\
\hline SO & 15 & 8 & & & $\begin{array}{lll}0 & 0 & 7\end{array}$ & & SD & 9 & 44 & & & 0046 & \\
\hline $\bar{E}$ & 4 & 2.1 & & & $\begin{array}{llll}0 & 0 & 18\end{array}$ & & $\overline{I E}$ & 2 & 11 & & & 0012 & \\
\hline Fish & $\overline{F L} \quad \mathrm{~mm}$ & wt (g) & Sex & HCt & Cond & Other & \begin{tabular}{|l|l} 
Fish & F \\
\end{tabular} & FL $\mathrm{cmm}$ & Wt (g) & Sex & HCt & Cond & Other \\
\hline 3.1489 & Group If & Rwy 45 & lemp & $=45$ & Subgr & & 3.14 .89 & Group III & Rwy 45 & temp & $=45$ & & \\
\hline 1 & 112 & 145 & $M$ & 31 & 1032 & an & 1 & 116 & 17.1 & $M$ & & 1096 & Atost \\
\hline 2 & 113 & 163 & Md & 33 & $\begin{array}{ll}113 \\
\end{array}$ & 1 & 2 & 114 & 159 & $\mathrm{~F}$ & & 1073 & rad \\
\hline 3 & 123 & 202 & $M$ & 33 & 1086 & 1 & 3 & 152 & 359 & Md & & 1022 & pale \\
\hline 4 & 106 & 12 & $M$ & 33 & 1008 & 1 & 4 & 123 & 205 & $F$ & & 1102 & livers \\
\hline 5 & 122 & 196 & $M$ & 30 & 1079 & 1 & 5 & 117 & 18 & $F$ & & 1124 & \\
\hline 6 & 137 & 264 & $F$ & 31 & $\begin{array}{lll}1 & 027 \\
\end{array}$ & 1 & 6 & 147 & 344 & $F$ & & 1083 & \\
\hline 7 & 122 & 199 & Md & 39 & 1096 & 1 & 7 & 118 & 181 & $\mathrm{M}$ & & 1102 & \\
\hline 8 & 147 & 327 & Md & 36 & 1029 & 1 & 8 & 112 & 152 & $M$ & & 1082 & \\
\hline 9 & 162 & 486 & ind & 38 & 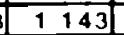 & 1 & 9 & 118 & \begin{tabular}{ll|}
193 \\
\end{tabular} & $\mathrm{~F}$ & & 1175 & \\
\hline 10 & 163 & 46 & Md & 32 & 1062 & 1 & 10 & 140 & 279 & $M d$ & & 1017 & \\
\hline 11 & 117 & 171 & $M$ & 29 & 1068 & 2 & 111 & 120 & 192 & $F$ & & 1111 & \\
\hline 12 & 117 & 175 & $F$ & 27 & 1093 & 2 & 12 & 125 & 217 & $F$ & & $\begin{array}{llll}1 & 1 & 11 \\
\end{array}$ & \\
\hline 13 & 116 & 18 & $M$ & 31 & 1153 & 2 & 13 & 124 & 219 & $M$ & & 1149 & \\
\hline 14 & 111 & 157 & $F$ & 31 & 1148 & 2 & 14 & 120 & 189 & $\mathbf{M}$ & & 1094 & \\
\hline 15 & 138 & 28 & $M$ & 30 & 1065 & 2 & 15 & 110 & 148 & $M$ & & 1112 & \\
\hline Ave & 127 & 235 & & 32 & 1081 & & Ave & 124 & \begin{tabular}{ll|}
21 & 3
\end{tabular} & & & 1097 & \\
\hline 50 & 18 & $\begin{array}{lll}11 & 1\end{array}$ & & 3 & 0047 & & $1 \infty$ & 10 & 36 & & & \begin{tabular}{lll|}
0 & 041 \\
\end{tabular} & \\
\hline$S$ & 5 & 291 & & & 0012 & & $S$ & 3 & 171 & & & \begin{tabular}{ll|}
0 & 01
\end{tabular} & \\
\hline
\end{tabular}




\begin{tabular}{|c|c|c|c|c|c|c|c|c|c|c|c|c|c|}
\hline \begin{tabular}{|l|l|} 
Fish & \\
3 & 14,89
\end{tabular} & \begin{tabular}{|l|} 
FL \\
Group
\end{tabular} & 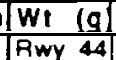 & $\frac{\mid \text { Sex }}{810}$ & $\frac{\mathrm{HCl}}{\text { Dam t }}$ & $\begin{array}{l}\text { TCond } \\
\text { temp }=45\end{array}$ & Jother & Fish & $F \mathrm{~L} \quad(\mathrm{~m} \mathrm{n}$ & Wi (a) & Sex & |Hct & Cond & Other \\
\hline & 1141 & $1 \quad 16$ & $M$ & & $t \quad 108$ & & \begin{tabular}{r|}
1 \\
\end{tabular} & 117 & 169 & & $1 \frac{2}{33}$ & -1055 & an \\
\hline 2 & 112 & 153 & Md & & 1089 & & 2 & 108 & $1 \cdot 1$ & $M$ & 34 & 1119 & 1 \\
\hline 3 & 115 & 177 & Md & & 1164 & & 3 & 110 & 149 & $F$ & 31 & 1119 & 1 \\
\hline 4 & 115 & 157 & $F$ & & 1032 & & 4 & 116 & 1711 & Mad & 35 & 1096 & 1 \\
\hline 5 & 115 & 179 & $F$ & & 1177 & & 5 & 116 & 161 & $F$ & 33 & 1031 & 1 \\
\hline 6 & 123 & 21 & $F$ & & 1129 & & 6 & 132 & $263 \mid$ & $M$ & 34 & 1143 & 1 \\
\hline 7 & 109 & 153 & $F$ & & 1181 & & 7 & 112 & 142 & Md & 36 & 10011 & 1 \\
\hline 8 & 112 & 167 & $F$ & & 1189 & & 8 & 105 & 135 & $F$ & 31 & 1166 & 2 \\
\hline 9 & 122 & 205 & $F$ & & 1129 & & 9 & 104 & 122 & $F$ & 30 & 1085 & 2 \\
\hline 10 & 107 & 124 & $F$ & & 1012 & & 10 & 119 & 178 & $F$ & 30 & 1056 & 2 \\
\hline 11 & 121 & 211 & $F$ & & 1191 & & 11 & 119 & 188 & $M$ & 31 & 1116 & 2 \\
\hline 12 & 130 & 255 & $M$ & & 1161 & & 12 & 110 & 148 & $M$ & 34 & 1112 & 2 \\
\hline 13 & 125 & $\begin{array}{lll}1 & 9 & 8 \\
\end{array}$ & $M$ & & 1014 & & 13 & 121 & 199 & $M$ & 32 & 1123 & 2 \\
\hline 14 & 136 & 286 & Md & & 1137 & & 54 & 1381 & 292 & $F$ & 33 & 1111 & 2 \\
\hline 15 & 147 & 323 & $F$ & & 1.017 & & 15 & 138 & 293 & Md & 34 & 1115 & 2 \\
\hline Ave & 120 & 197 & & & 1113 & & Ave & 118 & 183 & & 33 & 1097 & \\
\hline $50^{\circ}$ & -11 & 54 & & & $0 \quad 068$ & & SO & 11 & 56 & & 2 & 0042 & \\
\hline SE & -3 & 14 & & & $\begin{array}{llll}0 & 0 & 17\end{array}$ & & $\overline{S E}$ & 3 & 14 & & 1 & 0011 & \\
\hline Fish & $F L \quad(m m$ & wi la & Sex & HCT & Cond & Other & Fish & $\mathrm{FL} \quad(\mathrm{mm}$ & Wi git & Sex & $\mathrm{HCt}$ & Cond & Other \\
\hline $\begin{array}{|lll|}3 & 14 & 89 \\
\end{array}$ & Group III & R $m y$ 44 & $\operatorname{temp}$ & $p=45$ & & & $\begin{array}{|llll|}3 & 13 & 89 \\
\end{array}$ & Group 1 & $A_{w y} 43$ & $500 \mathrm{p}$ & on le & $e m p=45$ & \\
\hline 1 & $\begin{array}{r}117 \\
\end{array}$ & $\begin{array}{r}191 \\
\end{array}$ & $M$ & & 1193 & & \begin{tabular}{|r|}
1 \\
\end{tabular} & 105 & 121 & $\mathrm{~F}$ & & 1045 & \\
\hline 2 & 110 & $15:$ & $=$ & & 4134 & & 2 & 112 & 158 & $M$ & & 1125 & \\
\hline 3 & 116 & 178 & $F$ & & 114 & & 3 & 105 & 134 & $F$ & & $\begin{array}{lll}1 & 158 \\
\end{array}$ & \\
\hline$=4$ & 120 & 193 & $\mathrm{Mp}_{\mathrm{B}}$ & & $\begin{array}{ll}1 & 1171 \\
\end{array}$ & & 4 & -103 & $\square^{1} 118$ & $M_{2}$ & & 108 & \\
\hline 5 & 144 & 334 & $\mathrm{~F}-$ & & 1119 & & 5 & 223 & 1.1. & I- & & 1055 & \\
\hline & 137 & 2787 & Md & & 1081 & & 6 & 107 & $124 \mathrm{~F}$ & $\mathrm{~F}$ & & 1012 & \\
\hline & ii: & $\because=-i$ & & & 12 & & & & & & & & \\
\hline 1 & $+4 a$ & โิ3 1 & $\bar{a}$ & & $10 E=$ & & 하 & $10 \overline{8}$ & $\bar{A}, \bar{A}$ & $\hat{M}$ & & $1 \hat{119}$ & \\
\hline 9 & 114 & 158 & $F$ & & 1 nEs & & 9 & -109 & $132 \mathrm{~N}$ & $M$ & & $\begin{array}{ll}1 & 019 \\
\end{array}$ & \\
\hline 10 & 121 & 197 & $\bar{M}$ & & \begin{tabular}{lll|} 
& 1 & 1 \\
\end{tabular} & & 10 & 116 & 164 & $M$ & & 1051 & \\
\hline 11 & 120 & 194 & M & & 1123 & & 11 & 128 & 25 五 & Md & & 1216 & \\
\hline 12 & 158 & 406 & $M$ & & 1029 & & 12 & 1.32 & 2476 & Md & & 1074 & \\
\hline 13 & 118 & 181 & $M A$ & & 1102 & & 13 & 135 & 268 & MA & & 1089 & \\
\hline 14 & 115 & 16 & $F$ & & 1052 & & 14 & 137 & 306 & $F$ & & 119 & \\
\hline & 135 & 27 & $F$ & & 1097 & & 15 & 147 & 3431 & $\mathrm{Md}$ & & 108 & \\
\hline Ave & 125 & 222 & & & 1098 & & Ave & .117 & 185 & & & 1091 & \\
\hline 50 & 15 & 78 & & & $00 \overline{43}$ & & So & 15 & 77 & & & 006 & \\
\hline SE & 4 & 2 & & & $\begin{array}{lll}0 & 011 \\
\end{array}$ & & $\bar{E}$ & 4 & 21 & & & $\begin{array}{ll}0 & 015 \\
\end{array}$ & \\
\hline Fish & $F L \quad(\mathrm{~mm}$ & Wi (g) & Sex & L HCt & Cond & Other & Fish. & $(\mathrm{m}$ in & W Wi 19 & $9 \int \operatorname{sex}$ & $\mathrm{HC}$ & Cond & Other \\
\hline $3: 13.89$ & Group II & Rwy 43| & lemp: & $=45$ & & subgroup & $\mid 3: 13: 89$ & Group III & $9 w y \_43 \mid t$ & temp= & $=4-5$ & & \\
\hline 1 & 106 & 119 & \begin{tabular}{|l|} 
\\
\end{tabular} & 27 & $\begin{array}{ll}0 & 999 \\
\end{array}$ & an $=1$ & & 11 & & & & & \\
\hline 2 & 110 & 145 & $F$ & 36 & $\begin{array}{|ll|}1 & 089 \\
\end{array}$ & 1 & 2 & 14 & $25 \times 10$ & & & 1053 & \\
\hline 3. & 109 & 142 & $\mathbf{F}$ & 35 & I. 097 & & $3=$ & 1100 & TIF & & & 117 & \\
\hline 4 & 113 & 149 & $M$ & 41 & 1033 & 1 & 4 & 1331 & $27 \mathrm{glF}$ & & & 1 1 RA & \\
\hline 5 & 102 & 117 & mo & 39 & ! 10.7 & 1 & 51 & 110 & 1446 & $E$ & & 1082 & \\
\hline 6 & 122 & $19-1$ & Md & 34 & $\begin{array}{lll}1 & 052 \Gamma\end{array}$ & -1 & 6 & 128 & $24 \mathrm{JlF}$ & $\mathbf{F}$ & & 1149 & \\
\hline 7 & 157 & 408 & Md & 39 & 1054 & 1 & 7 & 1155 & $1541 \pi$ & $M$ & & 1013 & \\
\hline 8 & 163 & $49 \sqrt{3}$ & & 33 & 1138 & 1 & 8 & 159 & 38 |ㅣ & & & 0951 & \\
\hline 9 & 102 & 114 & $F$ & 35 & 1074 & 2 & 9 & 124 & $23 \sqrt{A}$ & Md & & 1206 & \\
\hline 10 & 101 & 103 & $F$ & 39 & & 21 & 10 & 140 & 3176 & & & 1155 & \\
\hline 11 & 97 & 99 & $\mathbf{F}$ & 29 & 1085 & 2 & 11 & 110 & 15 6lf & & & .1 .17 .31 & \\
\hline 12 & 114 & $152 !$ & & 3 Al & $102 \pi$ & ग1 & 13 & 112 & 15315 & & & 1 noa & \\
\hline 13 & 110 & $13 \overline{7}$ & $\overline{\mathbf{F}}$ & 331. & -1029 & 21 & 3 & 118 & $-19 \mid \mathrm{N}$ & $M$ & & . $\cup \cup 156$ & \\
\hline 14 & 107 & 128 & $F_{-}$ & 37 & 1045 & 2 & 14 & 115 & 17 N & $M$ & & $\begin{array}{lll}1 & 138 \\
\end{array}$ & \\
\hline 15 & 113 & 153 & $\mathbf{F}$ & 33 & $\begin{array}{ll}1 & 03\end{array}$ & 2 & 15 & 157 & $423 \mid \wedge$ & & & 1093 & \\
\hline$A \infty$ & 115 & 177 & & 35 & $\begin{array}{ll}1 & 059 \\
\end{array}$ & & Ave & 123 & 221 & & & 112 & \\
\hline 50 & 19 & 115 & & 4 & $\begin{array}{lll}0 & 0391 \\
\end{array}$ & & $\mathrm{SO}$ & 17 & 921 & & & $\begin{array}{lll}0 & 0731\end{array}$ & \\
\hline SE & -5 & 3 & & 1 & 001 & & 15 & $-4 L$ & 24 L & & & -0019 & \\
\hline
\end{tabular}




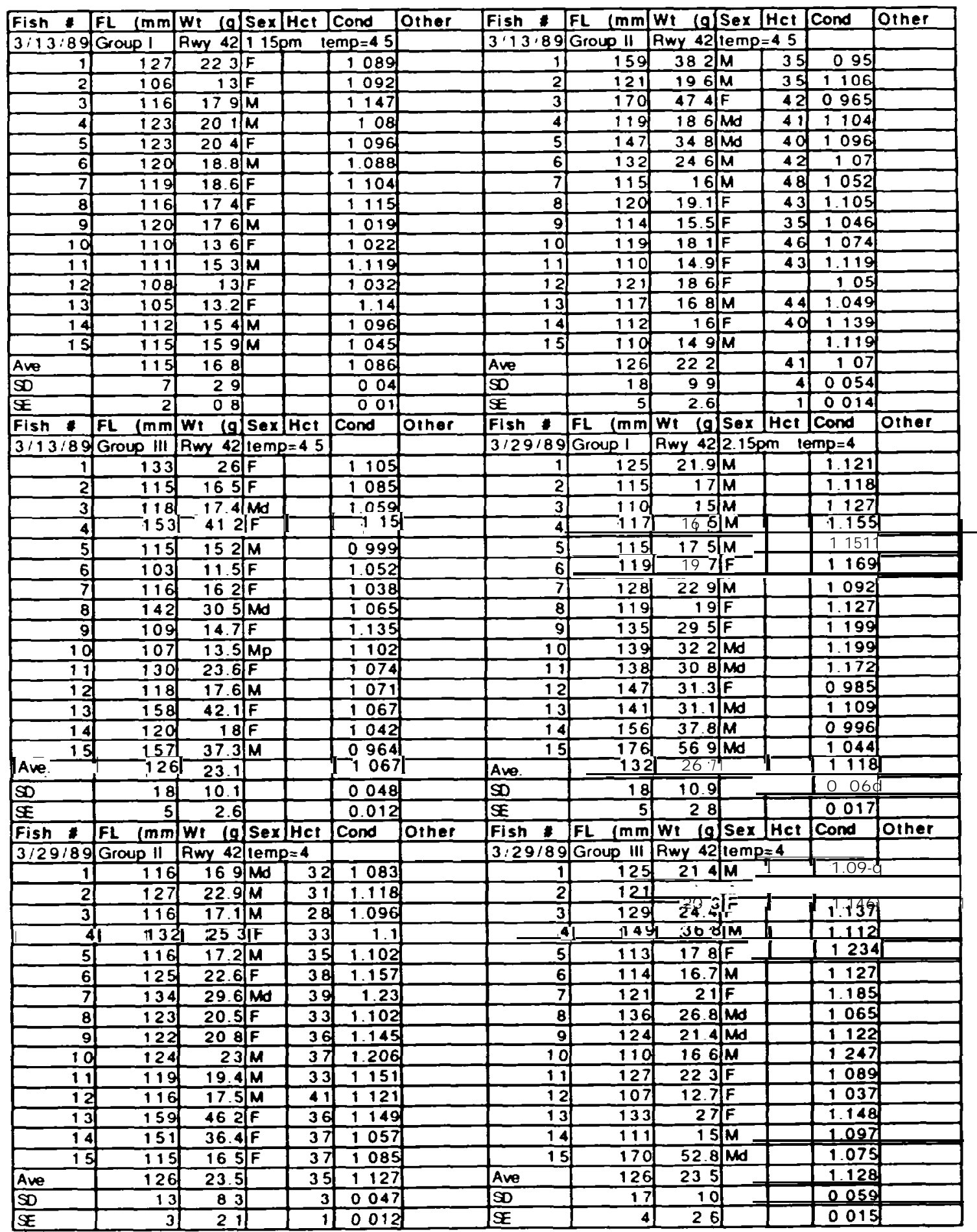




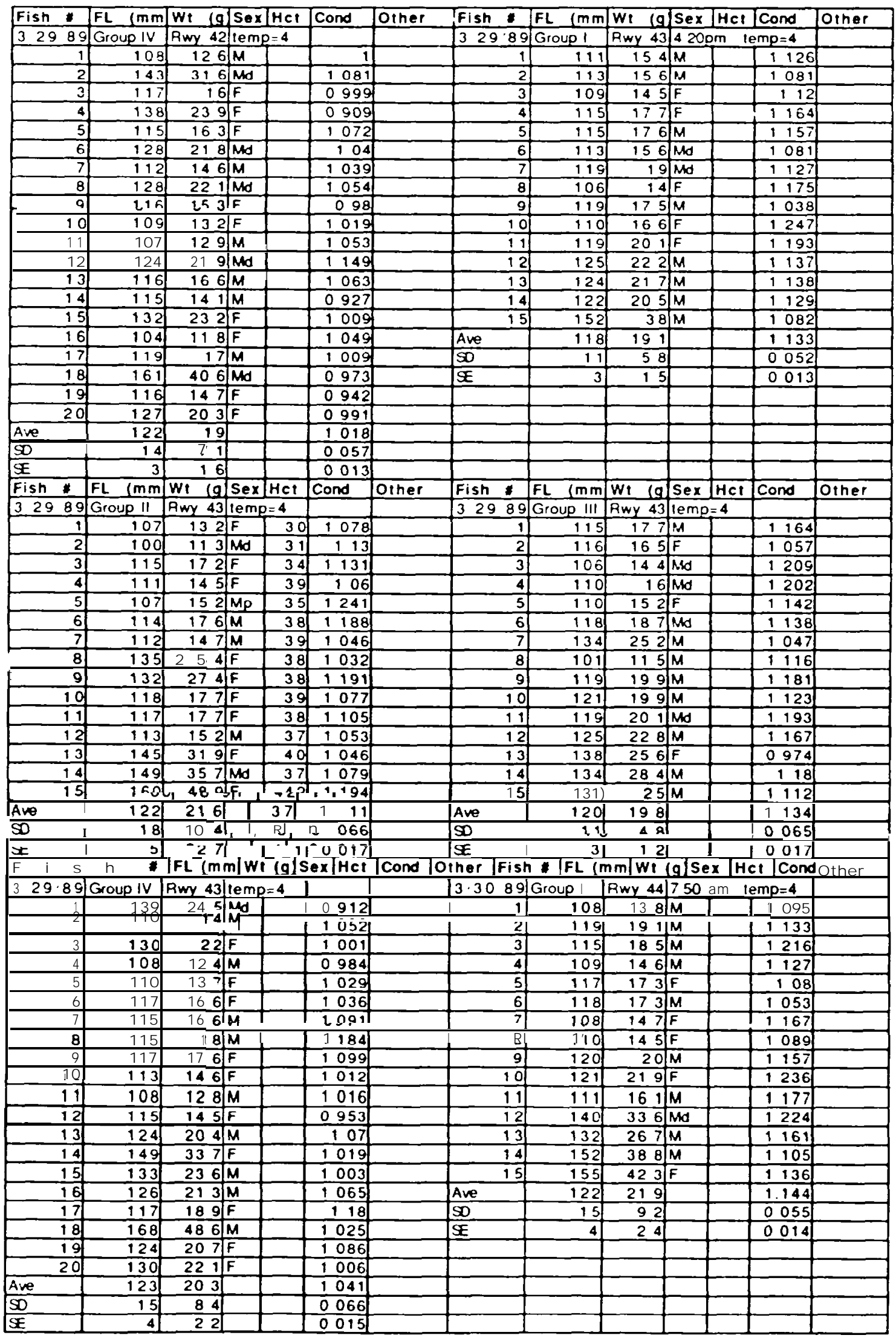




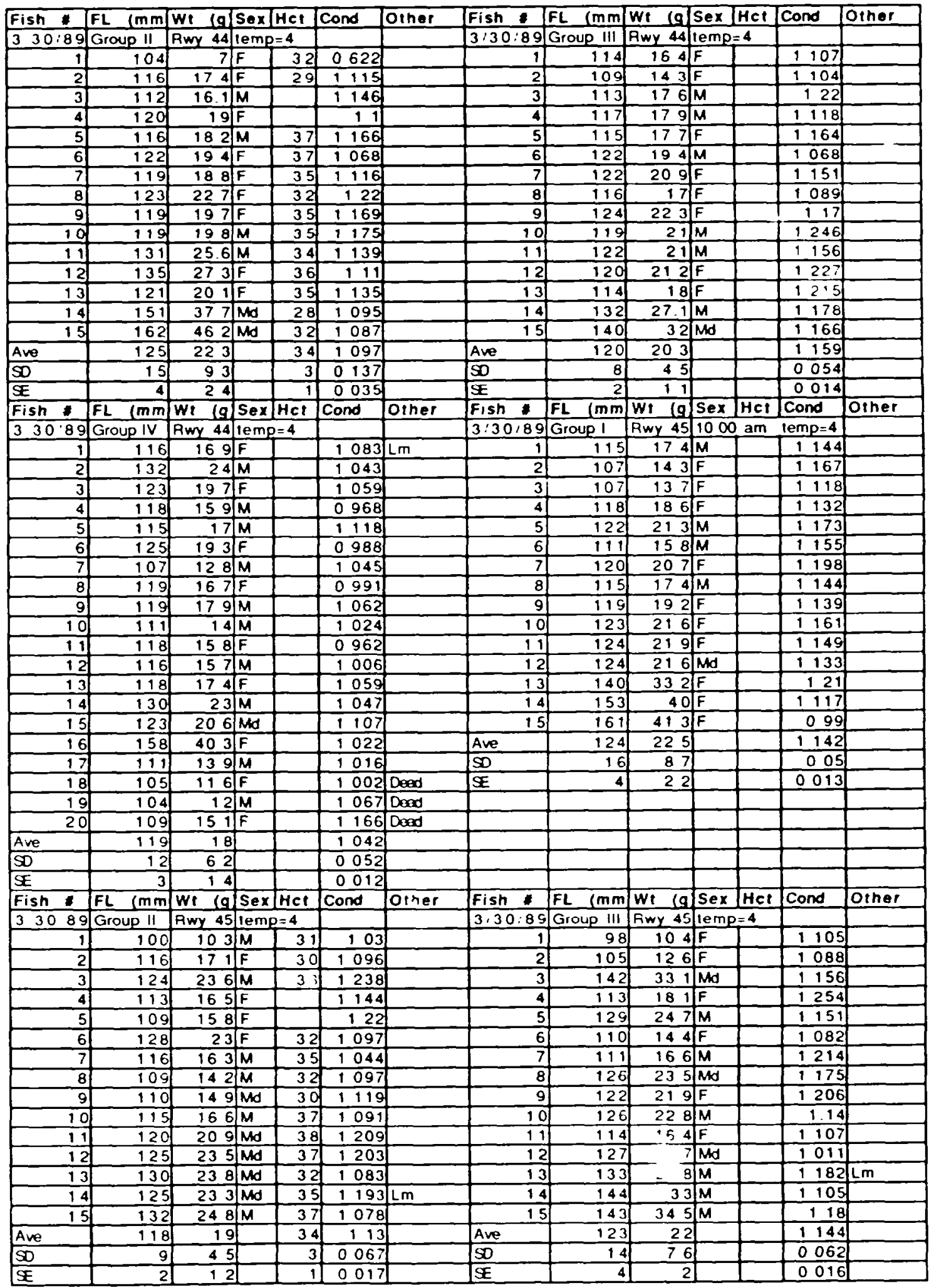




\begin{tabular}{|c|c|c|c|c|c|c|c|c|c|c|c|c|c|}
\hline Fish & $F L \quad(\mathrm{~mm}$ & Wt la & Sex & HCt & Cond & Other & Fish & $\mathrm{FL} \quad \mathrm{mm}$ & wi 19 & Sex & $\mathrm{HCl}$ & Cond & Other \\
\hline $3: 30.89$ & Group IV & Pay 45 & $\operatorname{temp}$ & $Q=4$ & & & $4: 12189$ & Group I & Rwy 42 & 1020 & $a m$ & $18 \mathrm{mp}=6$ & 5 \\
\hline 1 & \begin{tabular}{|r|}
117 \\
\end{tabular} & 161 & $M$ & & 1005 & & 1 & 119 & 186 & $F$ & & 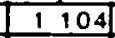 & \\
\hline 2 & 115 & 163 & $F$ & & 1072 & & 2 & 117 & 186 & $F$ & & 1161 & \\
\hline 3 & 113 & 145 & $F$ & & 1005 & & 3 & 123 & 222 & $\mathbf{F}$ & & 1193 & \\
\hline 4 & 106 & 119 & $F$ & & 0999 & & 4 & 124 & 229 & $F$ & & 1201 & \\
\hline 5 & 117 & 164 & $M$ & & 1024 & & 5 & 122 & 23 & $M$ & & 1267 & \\
\hline 6) & 123 & 183 & $F$ & & 0983 & & 6 & 121 & 202 & Md & & 114 & \\
\hline 7 & 115 & 147 & $F$ & & 0967 & & 7 & 118 & 182 & $M$ & & 1108 & \\
\hline 8 & 115 & 151 & $M$ & & 0993 & & 8 & 120 & 187 & $M$ & & 1082 & \\
\hline 9 & 114 & 158 & $M$ & & 1066 & & 9 & 117 & 18 & $F$ & & \begin{tabular}{lll|}
1 & 124 \\
\end{tabular} & \\
\hline 10 & 115 & 154 & $M$ & & 1013 & & 10 & 114 & 165 & $F$ & & $1 \quad 114$ & \\
\hline 11 & 142 & 308 & $M$ & & 1076 & & 11 & 114 & 165 & $F$ & & 1114 & \\
\hline 12 & 141 & 309 & $F$ & & 1102 & & 12 & 116 & 177 & $M$ & & 1134 & \\
\hline 13 & 117 & 178 & $F$ & & 1111 & & 13 & 126 & 236 & $M$ & & 118 & \\
\hline 14 & 118 & 164 & $F$ & & 0998 & & 14 & 128 & 252 & $F$ & & 1202 & \\
\hline 15 & 109 & 125 & $M$ & & 0965 & & 15 & 175 & 591 & $M$ & & 1.103 & \\
\hline 16 & 115 & 161 & $\mathbf{F}$ & & $\begin{array}{lll}1 & 059 \\
\end{array}$ & & Ave & 124 & 226 & & & 1948 & \\
\hline 17 & 114 & 145 & $M$ & & 0979 & & SO & 15 & 105 & & & $\begin{array}{lllll}0 & 0 & 51 & 1\end{array}$ & \\
\hline 18 & 147 & 341 & Md & & 1074 & & $S E$ & 4 & 27 & & & $\begin{array}{llll}0 & 0 & 13 \\
\end{array}$ & \\
\hline 19 & 158 & 39 & $F$ & & 0989 & & & & & & & & \\
\hline 20 & 117 & 153 & $F$ & & 0955 & & & & & & & & \\
\hline Ave & 121 & 191 & & & 1022 & & & & & & & & \\
\hline SO & 14 & 78 & & & 0048 & & & & & & & & \\
\hline$\overline{S E}$ & 3 & 17 & & & $\begin{array}{llll}0 & 0 & 1 & 1\end{array}$ & & & & & & & & \\
\hline Fish & $F L \quad(\mathrm{~mm}$ & $W_{t}$ (a) & Sex & Hot & Cond & Oiner & Fish & FL $\quad(\mathrm{mm}$ & wi $(g)$ & $\operatorname{sex}$ & Hct & Cond & Other \\
\hline 4.12 .89 & Group II & Rwy 42 & temp & $=65$ & & Subgrp\# & 411289 & Group III & Rny 42 & temp= & $=65$ & & \\
\hline 1 & \begin{tabular}{|r|}
123 \\
\end{tabular} & 21 & $F$ & 26 & 1129 & $1 . \mathrm{Lm}$ & \begin{tabular}{|r|} 
\\
\end{tabular} & $10 \mathrm{~g}$ & \begin{tabular}{|l|}
143 \\
\end{tabular} & \begin{tabular}{|l|l|}
$F$ & \\
\end{tabular} & & 1104 & \\
\hline 2 & 122 & 205 & $M$ & 36 & 1129 & 1 & 2 & 148 & 376 & $M$ & & 116 & \\
\hline 3 & 129 & 248 & $\mathrm{Md}$ & 31 & 1155 & 1 & 3 & 131 & 278 & Md & & 1237 & \\
\hline 4 & 122 & $\begin{array}{lll}91 & 19 \\
\end{array}$ & Md & 30 & 1052 & 1 & 4 & 135 & 282 & $F$ & & 1158 & \\
\hline 5 & 159 & 438 & Ad & 31 & 109 & 1 & 5 & 138 & 285 & $F$ & & 1084 & \\
\hline 6 & 142 & 288 & $F$ & 30 & 1006 & 1 & 6 & 113 & 152 & $F$ & & 1053 & \\
\hline 7 & 150 & 38 & Md & 38 & 1126 & 1 & 7 & 129 & 258 & Md & & 1202 & \\
\hline 8 & 162 & 498 & Md & 35 & 1171 & 1 & 8 & 115 & 173 & $M$ & & 1138 & \\
\hline 9 & 165 & 525 & $F$ & 41 & 1169 & 1 & 9 & 136 & 278 & $F$ & & 1105 & \\
\hline 10 & 128 & 24 & Md & 27 & 1144 & 2 & 10 & 123 & 208 & $\mathbf{F}$ & & 1118 & \\
\hline 11 & 120 & 188 & $F$ & 32 & 1088 & 2 & 11 & 132 & 276 & Md & & 12 & \\
\hline 12 & 117 & 169 & $F$ & 29 & 1055 & 2 & 12 & 137 & 288 & $M$ & & 112 & \\
\hline 13 & 121 & 194 & $M$ & 36 & 1095 & 2 & 13 & 127 & 22.6 & $\mathbf{F}$ & & 1103 & \\
\hline 14 & 121 & 209 & $M$ & 55 & 118 & 2 & 14 & 147 & 328 & Md & & 1033 & \\
\hline 15 & 126 & 241 & $F$ & 39 & 1205 & 2 & 15 & 160 & 444 & $\overline{\mathbf{F}}$ & & 1084 & \\
\hline Ave & 134 & 282 & & 34 & 112 & & Ave & 132 & 266 & & & \begin{tabular}{ll|}
1127 \\
\end{tabular} & \\
\hline $\mathrm{SO}$ & 17 & 12 & & 7 & $\begin{array}{lll}0 & 0 & 55 \\
\end{array}$ & & SO & 14 & 81 & & & 0.057 & \\
\hline $\mathscr{E}$ & 4 & \begin{tabular}{|r|}
31 \\
\end{tabular} & & 2 & $\begin{array}{lllll}0 & 0 & 14\end{array}$ & & I & 4 & 2.1 & & & $\begin{array}{llll}0 & 0 & 15\end{array}$ & \\
\hline Fish & $\mathrm{FL} \quad \mathrm{mm}$ & $\begin{array}{|ll|}w_{1} & \text { (g) } \\
\end{array}$ & Sex & \begin{tabular}{|l|} 
HCt \\
\end{tabular} & Cond & Other & Fish & $F L \quad(\mathrm{~mm}$ & Wt $\quad$ (g) & Sex & $\mathrm{HCl}$ & Cond & Other \\
\hline $\begin{array}{llll}4 & 12 & 89 \\
\end{array}$ & Group IV & Rwy 42 & temp & $0=65$ & & & $4: 12: 89$ & Group I & Awy 43 & $130 \mathrm{~F}$ & $\mathrm{pm}$ is & lemp $=65$ & \\
\hline 1 & \begin{tabular}{|l|}
111 \\
\end{tabular} & \begin{tabular}{|r|}
127 \\
\end{tabular} & $M$ & & 0929 & & \begin{tabular}{|r|}
1 \\
\end{tabular} & \begin{tabular}{|l|}
113 \\
\end{tabular} & \begin{tabular}{|r|}
17 \\
\end{tabular} & $M$ & & 1178 & \\
\hline 2 & 115 & 17 & $F$ & & 1118 & & 2 & 115 & 1731 & $M$ & & 1138 & \\
\hline 3 & 115 & 187 & $F$ & & 123 & & 3 & 113 & 166 & $F$ & & 115 & \\
\hline 4 & 117 & 17 & $F$ & & 1061 & & 4 & 110 & 1531 & $\mathbf{M}$ & & $\begin{array}{ll}1 & 15 \\
\end{array}$ & \\
\hline 5. & 113 & 151 & $F$ & & 1047 & & 5 & 112 & 165 & $F$ & & 1174 & \\
\hline 6] & 117 & 164 & $F$ & & 1024 & & 6 & 103 & 1241 & $M$ & & 1135 & \\
\hline 7 & 108 & 121 & $F$ & & 0961 & & 7 & 115 & $17 / f$ & $\mathrm{~F}$ & & $\begin{array}{|lll|}1 & 1 & 18 \\
\end{array}$ & \\
\hline 8 & 110 & 12.5 & $M$ & & 0939 & & 8 & 103 & 128 & $\bar{M}$ & & 1.171 & \\
\hline 9 & 132 & 22 & $M$ & & 0957 & & 9 & 117 & 208 & Md & & 1299 & \\
\hline 10 & 114 & 149 & $F$ & & 1006 & & 10 & 115 & $\begin{array}{lll}18 & 1 \\
\end{array}$ & $\mathbf{M}$ & & 119 & \\
\hline 11 & 130 & 239 & Md & & 1088 & & 11 & 116 & 171 & $\mathbf{M}$ & & 1096 & \\
\hline 12 & 123 & 1931 & $M$ & & 1037 & & 12 & 123 & 2131 & $M$ & & 1145 & \\
\hline 13 & 125 & 209 & Md & & 107 & & 13 & 133 & 269 & Md & & 1143 & \\
\hline 14 & 120 & 164 & $F$ & & 0949 & & 14 & 125 & $224 / 1$ & $M$ & & 1147 & \\
\hline 15 & 163 & 474 & Md & & 1094 & & 15 & 156 & 3810 & $\bar{M}$ & & 1004 & \\
\hline 16 & 112 & 142 & $M$ & & $\begin{array}{llll}1 & 0 & 11\end{array}$ & & Ave & 118 & 193 & & & 1149 & \\
\hline 17 & 123 & 1911 & $M$ & & $\begin{array}{lll}1 & 026\end{array}$ & & SO & 13 & 64 & & & 0061 & \\
\hline 18 & 154 & 361 & $M$ & & 0986 & & $\mathbf{I}$ & 3 & 16 & & & 0016 & \\
\hline 19 & 109 & 137 & $F$ & & 1058 & Dexnd & & & & & & & \\
\hline 20 & 123 & 1721 & $M$ & & 0924 & Doand & & & & & & & \\
\hline Ave & 122 & 193 & & & 1026 & & & & & & & & \\
\hline 50 & 14 & 85 & & & $\begin{array}{llll}0 & 0 & 75\end{array}$ & & & & & & & & \\
\hline$\Phi$ & 3 & $\begin{array}{ll}22 \\
\end{array}$ & & & $\begin{array}{llll}0 & 0 & 17\end{array}$ & & & & & & & & \\
\hline
\end{tabular}




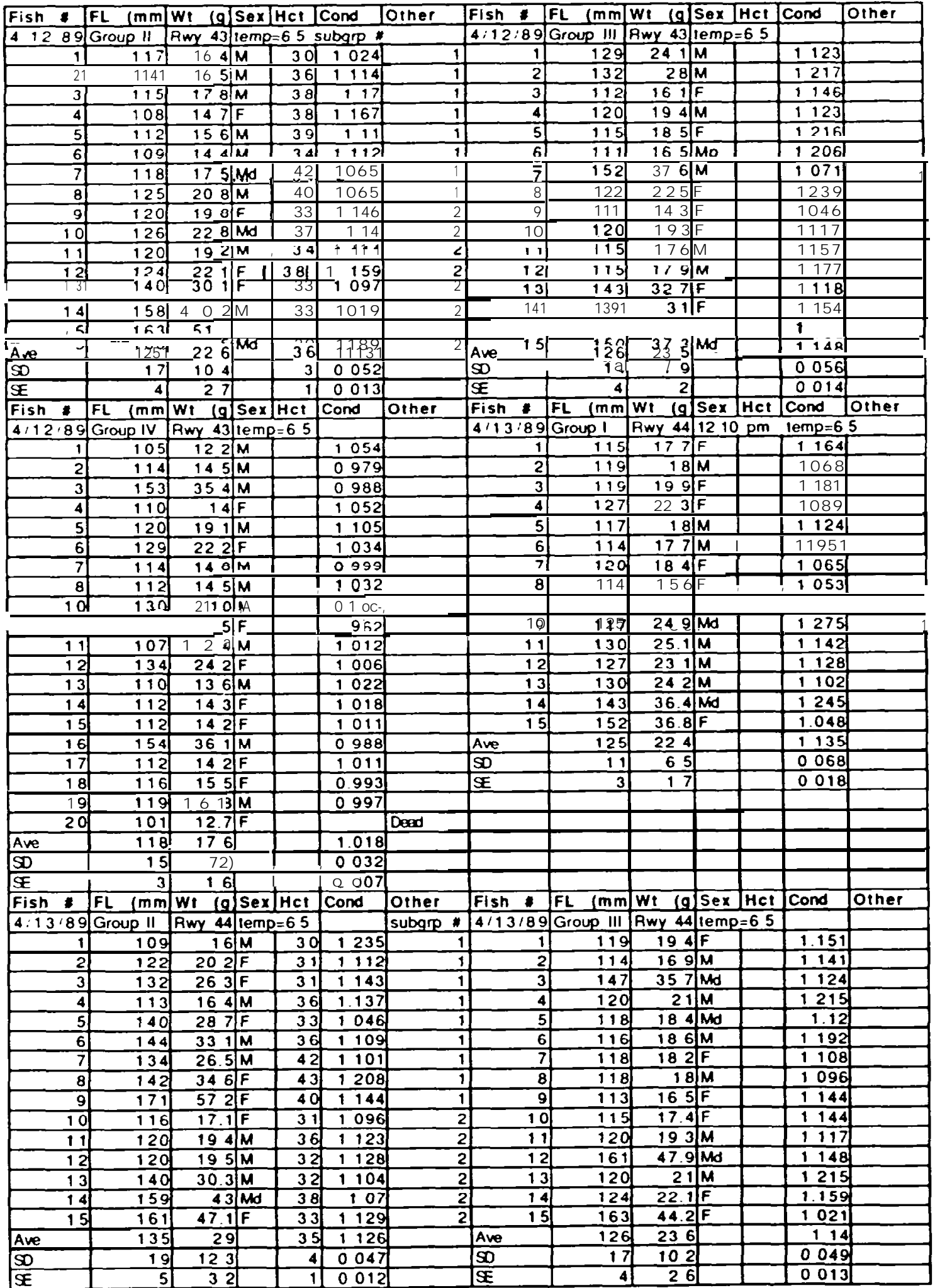




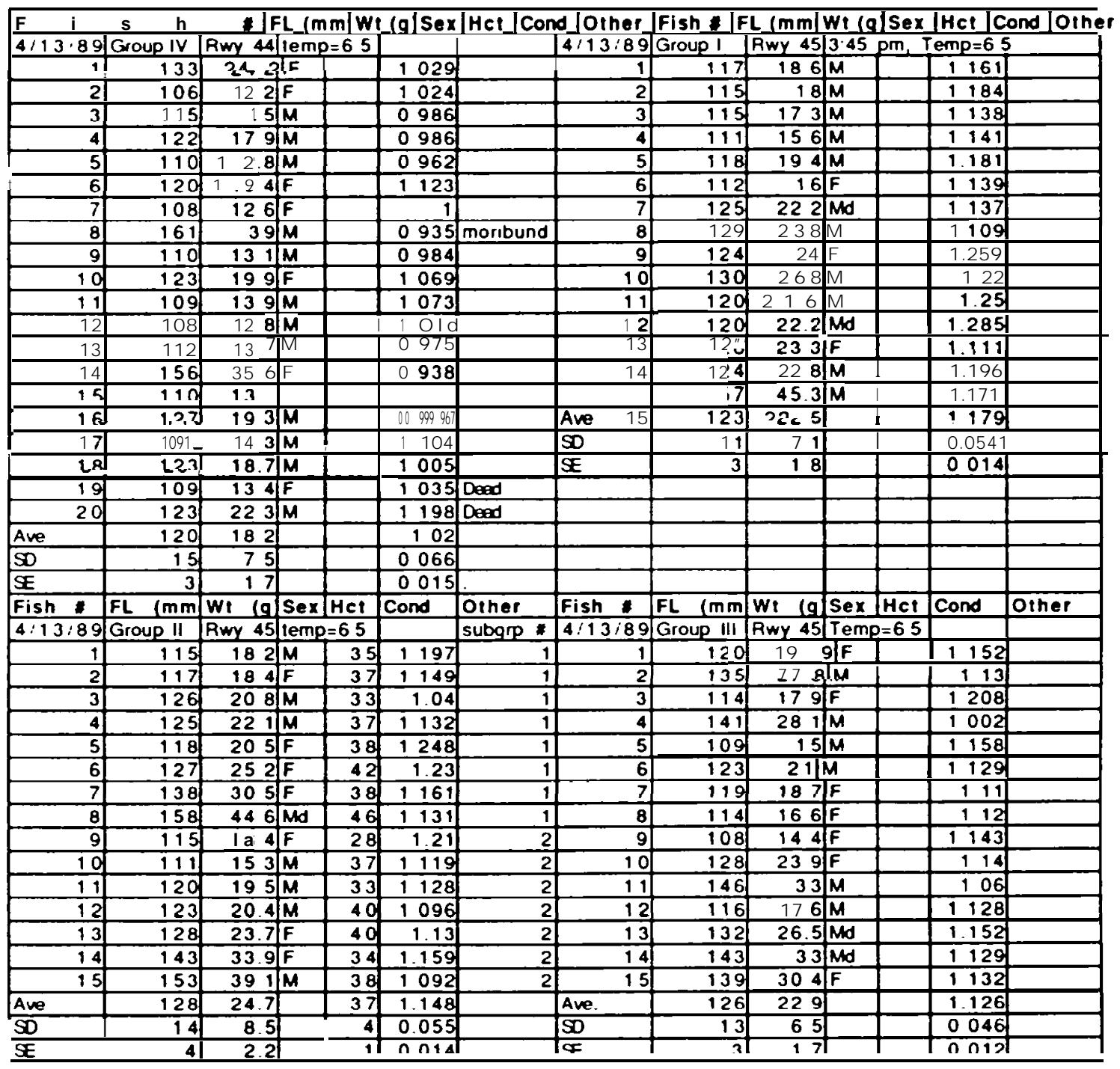




\begin{tabular}{|c|c|c|c|c|c|c|c|c|c|c|c|c|c|}
\hline Fish $*$ & FL $1 \mathrm{~mm}$ & Wt $(\mathrm{gl}$ & Sex & $\mathrm{Hct}$ & Cond & Other & \begin{tabular}{|l|l|l|} 
Fish 8 & \\
\end{tabular} & $\overline{F L}(\mathrm{~mm}$ & Wt lals & Sex & $\mathrm{HCl}$ & Cond & Other \\
\hline 413895 & Group IV & Rwy 45 & tem & $n p=65$ & & & 41489 & Group \# & Pwy $42 \mathrm{c}$ & crowde & ed & & \\
\hline 1 & \begin{tabular}{r|}
165 \\
\end{tabular} & 44 & Md & & 0979 & & \begin{tabular}{r|}
1 \\
\end{tabular} & \begin{tabular}{|r|}
110 \\
\end{tabular} & $\begin{array}{lll}51 & 15 \\
\end{array}$ & \begin{tabular}{|l|}
$\mathbf{M}$ \\
\end{tabular} & 30 & 1134 & \\
\hline 2 & 105 & 114 & $F$ & & 0985 & & 2 & 104 & 1331 & $F$ & 33 & 1182 & \\
\hline 3 & 115 & 158 & $F$ & & 1039 & & 3 & 115 & 174 & $M$ & 35 & 1144 & \\
\hline 4 & 114 & 147 & $M$ & & 0992 & & 4 & 119 & 198 & $M$ & 26 & 1175 & \\
\hline 5 & 116 & 161 & $M$ & & 1031 & & 5 & 118 & 186 & $M$ & 36 & 1132 & \\
\hline 6 & 107 & 126 & $F$ & & 1029 & & 6 & 113 & 164 & $F$ & 35 & 1109 & \\
\hline 7 & 125 & 204 & $M$ & & $\begin{array}{ll}102 \\
\end{array}$ & & 7 & 130 & 249 & $F$ & 32 & 1133 & \\
\hline 8 & 104 & 118 & $M$ & & 1049 & & 8 & 122 & 2051 & $M$ & 42 & $\begin{array}{ll}1 & 129 \\
\end{array}$ & \\
\hline 9 & 148 & 331 & Md & & 1021 & & 9 & 112 & 178 & $F$ & 40 & 1267 & \\
\hline 10 & 11. & 162 & $F$ & & 1011 & & 10 & 113 & 17 & $F$ & 42 & 1178 & \\
\hline 11 & 123 & 20 & $F$ & & 1075 & & 11 & 120 & 172 & $M$ & 36 & 0.995 & \\
\hline 12 & 119 & 168 & $\mathrm{Md}$ & & 0997 & & 12 & 118 & 195 & $M$ & 45 & 1187 & \\
\hline 13 & 117 & 164 & Md & & 1024 & & 13 & 125 & 208 & $M$ & 40 & 1065 & \\
\hline 14 & 119 & 17 & $M$ & & 1009 & & 14 & 138 & 327 & $F$ & 30 & 1244 & \\
\hline 15 & 119 & 163 & $M$ & & $=0967$ & & 15 & 169 & $51 \mathrm{~B}$ & $M$ & 36 & 1073 & \\
\hline 16 & 114 & 147 & $M$ & & 0992 & & Ave & 122 & 215 & & 36 & 1148 & \\
\hline 17 & 121 & 166 & $M$ & & 0937 & & SO & 15 & 961 & & 5 & 0068 & \\
\hline 18 & 116 & 163 & $F$ & & 1044 & & SE & 4 & 25 & & 1 & 0018 & \\
\hline 19 & 93 & 84 & $F$ & & .044 & Dend & & & & L & & & \\
\hline 20 & 112 & 143 & $F$ & & 1018 & Doed & & & & & & & \\
\hline Ave & 114 & 1761 & & & 1013 & & & & & & & & \\
\hline 5 & 15 & 78 & & & 0032 & & & & & & & & \\
\hline SF & 3 & 18 & & & 0007 & & & & & & & & \\
\hline Fish & FL $(\mathrm{mm}$ & Wt (g) & $\operatorname{sex}$ & $\mathrm{HCt}$ & Cond & Other & Fish & $\mathrm{FL} \quad \mathrm{mm}$ & wi lal & $\operatorname{sex}$ & $\mathrm{HCt}$ & Cond & Other \\
\hline $4.14 \quad 89$ & Group 111 & RwY $42 \mathrm{C}$ & crowd & sed & & & 414.89 & FL of olne & er fish in & sample & le rwy & 42 & \\
\hline 1 & $\begin{array}{r}108 \\
\end{array}$ & \begin{tabular}{|l|}
152 \\
\end{tabular} & \begin{tabular}{|l|l|}
$F$ \\
\end{tabular} & & 1207 & & \begin{tabular}{r|}
1 \\
\end{tabular} & \begin{tabular}{|l|}
116 \\
\end{tabular} & 126 & 119 & & & \\
\hline 2 & 146 & 367 & $M$ & & 1179 & & 2 & 120 & 112 & 136 & & & \\
\hline 3 & 115 & 174 & $F$ & & 1144 & & 3 & 116 & 114 & 111 & & & \\
\hline 4 & 123 & 201 & $F$ & & 108 & & 4 & 140 & $\begin{array}{lll}1 & 3 & 11\end{array}$ & 126 & & & \\
\hline 5 & 128 & 2311 & $M$ & & 1101 & & 5 & 144 & 132 & 137 & & & \\
\hline 6 & 116 & 174 & $F$ & & 1115 & & 6 & 114 & 121 & 127 & & & \\
\hline 7 & 152 & 394 & $F$ & & 1122 & & 7 & 117 & 119 & 120 & & & \\
\hline 8 & 119 & 189 & $M$ & & 1122 & & 8 & 127 & 119 & 128 & & & \\
\hline 91 & 115 & 187 & $M$ & & 123 & & 9 & 115 & 127 & 145 & & & \\
\hline 10 & 117 & 174 & $M$ & & 1086 & & 10 & 133 & 118 & 121 & & & \\
\hline 11 & 112 & 163 & $F$ & & $\begin{array}{ll}1 & 16 \\
\end{array}$ & & 11) & 116 & 113 & 143 & & & \\
\hline 12 & 130 & 258 & $F$ & & 1174 & & 12 & 123 & 121 & 127 & & & \\
\hline 13 & 119 & 188 & $F$ & & 1116 & & 13 & 128 & 119 & 151 & & & \\
\hline 14 & 123 & 192 & $\mathbf{F}$ & & 1032 & & 14 & 121 & 114 & 134 & & & \\
\hline 15 & 175 & 606 & Md & & 1131 & & 15 & 115 & 115 & 119 & & & \\
\hline Ave & 127 & 243 & & & 1133 & & 16 & 129 & 119 & & & & \\
\hline 50 & 18 & 123 & & & 0051 & & 17 & 168 & 126 & & & & \\
\hline$S$ & 5 & 32 & & & 0031 & & 18 & 127 & 125 & & & & \\
\hline & & & & & & & 1 al & 114 & 119 & & & & \\
\hline & & & & & & & 20 & 116 & 118 & & & & \\
\hline & & & & & & & Ave & 125 & & & & & \\
\hline & & & & & & & 50 & 11 & & & & & \\
\hline & & & & & & & $\mathbf{S}$ & \begin{tabular}{|r|} 
\\
\end{tabular} & & & & & \\
\hline Fish \# & FL $\quad(\mathrm{mm}$ & Wt $(\mathrm{gl}$ & $\operatorname{sex}$ & $\mathrm{HCl}$ & Cond & Oiher & Fish & FL $\quad \mathrm{mm}$ & Wi la & $\operatorname{sex}$ & Hct & Cond & Other \\
\hline 414.89 & Group II & Rwy 450 & crowd & Jed & & & \begin{tabular}{|l|l|}
$4 / 14$ & 89 \\
\end{tabular} & Group III & Rwy $45 \mathrm{c}$ & crowde & ed & & \\
\hline 1 & \begin{tabular}{r|}
113 \\
\end{tabular} & $\begin{array}{ll}1633 \\
\end{array}$ & \begin{tabular}{|l|}
$F$ \\
\end{tabular} & 36 & 113 & & \begin{tabular}{r|}
1 \\
\end{tabular} & 144 & 338 & $F$ & & 1132 & \\
\hline 2 & 115 & 185 & $M$ & 34 & 1216 & & 2 & 118 & 208 & $F$ & & 1266 & \\
\hline 3 & 117 & 184 & $M$ & 29 & 1149 & & 3 & 118 & 202 & $F$ & & 1229 & \\
\hline 4 & 122 & 205 & $M$ & 37 & 1129 & & 4 & 112 & 166 & $F$ & & 1182 & \\
\hline & 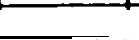 & $3 \mid$ & $M$ & 36 & 128 & & 5 & 115 & 18 & $F$ & & 1184 & \\
\hline 7 & 11112 & $20198 \%$ & $h$ & 33 & $1146 \quad 1157$ & & 67 & 1118 & 22195 & $F$ & & 1187 & \\
\hline 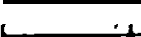 & . . & $\ldots 11$ & $r$ & إل & & & & & $? 9$ & $M$ & & 1172 & \\
\hline 8 & 122 & 206 & $F$ & 39 & 1134 & & 8 & 142 & 343 & $F$ & & 1198 & \\
\hline 9 & 109 & 157 & $F$ & 38 & 1212 & & 9 & 120 & 212 & $F$ & & 1227 & \\
\hline 10 & 121 & 209 & $F$ & 37 & 118 & & 10 & 118 & 177 & Md & & 1077 & \\
\hline 11 & 121 & 200 & $M$ & 40 & 1135 & & 11 & 121 & 206 & $F$ & & 1163 & \\
\hline 12 & 121 & 209 & $F$ & 38 & $\begin{array}{ll}118 \\
\end{array}$ & & 12 & 118 & 188 & $M$ & & 1144 & \\
\hline 13 & 130 & 253 & $F$ & 41 & 1152 & & 13 & 146 & 35 & Md & & 1125 & \\
\hline 14 & 131 & \begin{tabular}{|l|l|}
28 & 3 \\
\end{tabular} & $\mathbf{F}$ & 37 & 1259 & & 14 & 130 & $\begin{array}{ll}27 & 1 \\
\end{array}$ & $M$ & & 1234 & \\
\hline 15 & 167 & 592 & $\mathbf{F}$ & 40 & 1271 & & 15 & 123 & 228 & $F$ & & 1225 & \\
\hline Are & 123 & 227 & & 37 & 1182 & & Ave & 125 & 233 & & & 1183 & \\
\hline 50 & 14 & 106 & & 3 & 0053 & & $\infty$ & 11 & 63 & & & 005 & \\
\hline $\bar{E}$ & 4 & 27 & & 1 & 00014 & & $\Phi$ & 3 & 166 & & & 00013 & \\
\hline
\end{tabular}




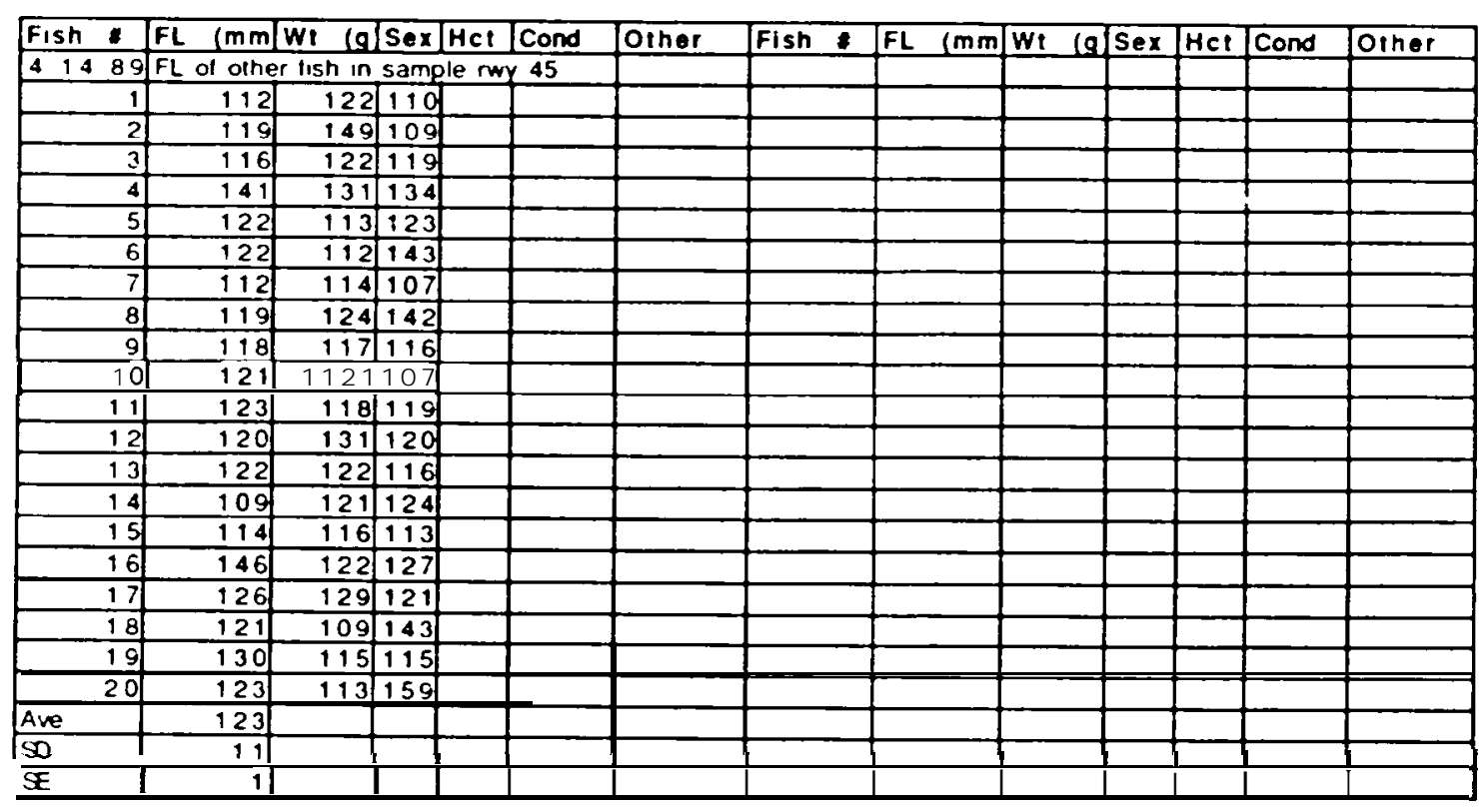




\begin{tabular}{|c|c|c|c|c|c|c|c|c|c|c|c|c|c|}
\hline Werm Spri & rings & Md=deve & $=0$ & 149116 & ale; $M_{p}=$ & =fully $d$ & eveloped, & precocio & lous $\mathrm{mal}$ & $10 ;$ & $A n=8 n$ & nemic & \\
\hline$L P=p a l e$ liv & ver; Lm= & mottled & live & $r_{i} T=0$ & coded & wire tog & B $B$ brand & ded & & & & & \\
\hline Fish & $\mathrm{FL}(\mathrm{mnn}$ & Wt (g) $\mid$ & Sex & Hat & Cond & Other & Fish & $\mathrm{FL}(\mathrm{mrnv}$ & Wi lals & Sex & $\mathrm{HCt}$ & Cond & Other \\
\hline $3: 6: 89$ & Group 1 & $\begin{array}{|ll|}A w x & 11 \\
\end{array}$ & 1220 & $\mathrm{pm}$ & $\operatorname{temp}=45$ & & $3: 6189$ & Group II F & Rwy 11 & temp & $p=45$ & & \\
\hline 1 & 127 & 21.7 & \begin{tabular}{|l|}
$M$ \\
\end{tabular} & & $\begin{array}{|ll|}1 & 059 \\
\end{array}$ & & 1 & 127 & \begin{tabular}{|l|}
2291 \\
\end{tabular} & \begin{tabular}{|l|} 
\\
\end{tabular} & 37 & 1118 & \\
\hline 2 & 141 & 345 & Md & & 1231 & & 2 & 131 & $255 \mathrm{~F}$ & $\mathbf{F}$ & 40 & $\begin{array}{llll}134 & \end{array}$ & LP \\
\hline 3 & 151 & 388 & $\mathbf{F}$ & & $\begin{array}{ll}127 \\
\end{array}$ & & 3 & 145 & $335 / F$ & $F$ & 41 & 1099 & \\
\hline 4 & 133 & 267 & $\mathbf{F}$ & & 1.135 & & 4 & 117 & 16.8 & $M$ & 44 & 1049 & \\
\hline 5 & 148 & 36.7 & $\mathbf{F}$ & & $\begin{array}{lll}1.132 & \mathrm{~L} \\
\end{array}$ & LP & 5 & 137 & 27 & $M$ & 44 & $\begin{array}{ll}1 & 05 \\
\end{array}$ & \\
\hline 6 & 146 & 33.2 & Md & & 1067 & & 6 & 157 & 454 & Md & 37 & 1.173 & \\
\hline 7 & 127 & 226 & Md & & 1103 & & 7 & 144 & 353 & $F$ & 40 & 1182 & \\
\hline 8 & 139 & 32.7 & $\mathbf{F}$ & & 1218 & & 8 & 116 & 176 & $\mathbf{F}$ & 36 & 1128 & \\
\hline 9 & 114 & 16 & $F$ & & 1.08 & & 9 & 138 & 29.1 & $\mathbf{M}$ & 42 & 1107 & \\
\hline 10 & 130 & 25.4 & $F$ & & 1156 & & 10 & 138 & 2831 & $M$ & 35 & 1077 & \\
\hline 11 & 125 & 21 & Md & & 1075 & & 11 & 124 & 22.7 & $M$ & 39 & $\begin{array}{lll}1 & 191 \\
\end{array}$ & \\
\hline 12 & 114 & 157 & $F$ & & 106 & & 12 & 135 & $276 \mathrm{~F}$ & $F$ & 39 & $\begin{array}{lll}1 & 122 & \\
\end{array}$ & LP \\
\hline 13 & 137 & 29.8 & $F$ & & $1.159 \mathrm{~L}$ & LP & 13 & 131 & $2471 \mathrm{~F}$ & $F$ & 41 & 1099 & \\
\hline 14 & 110 & 14.5 & $F$ & & 1089 & & 14 & 115 & 174 & $F$ & 40 & 1144 & \\
\hline 15 & 139 & 28.7 & $\sqrt[F]{ }$ & & 1069 & & 15 & 124 & 2031 & $\mathbf{M}$ & 32 & 1065 & \\
\hline Ave & 132 & 26.5 & & & 1117 & & Ave & 132 & 263 & & 39 & 1116 & \\
\hline $\mathbf{S O}$ & 13 & 78 & & & 0055 & & SO & 12 & 77 & & 3 & 0045 & \\
\hline$S$ & 3 & \begin{tabular}{r|}
2 \\
\end{tabular} & & & 0014 & & SE & 3 & \begin{tabular}{|r|}
2 \\
\end{tabular} & & 1 & 0012 & \\
\hline Fish & $F L \quad(m n$ & WI (g) & Sex & $\mathrm{HCl}$ & Cond & Other & FIsh & $F L \quad$ mnv & wi lal & Sex & HCl & Cond & Other \\
\hline $3: 6189$ & \begin{tabular}{|l|l} 
Group III \\
\end{tabular} & Rwy 11 & temp & $0=45$ & & & $3: 6: 89$ & Group I & Awy 13 & 340 & $\mathrm{pm}$ & temp $=45$ & \\
\hline \begin{tabular}{r|}
1 \\
\end{tabular} & \begin{tabular}{|l|}
143 \\
\end{tabular} & \begin{tabular}{|l|}
367 \\
\end{tabular} & $F$ & & 1.255 & & $\begin{array}{r}1 \\
\end{array}$ & 159 & 411 & \begin{tabular}{|l|l|}
$F$ \\
\end{tabular} & & $\begin{array}{lll}1 & 022 \\
\end{array}$ & \\
\hline 2 & 175 & 593 & $\mathbf{F}$ & & 1106 & & 2 & 135 & 2651 & $F$ & & 1077 & \\
\hline 3 & 146 & 359 & $\mathbf{F}$ & & 1154 & & 3 & 145 & 3121 & $\bar{M}$ & & $\begin{array}{lll} & 023 \\
\end{array}$ & \\
\hline 4 & 134 & 268 & $F$ & & $1114]$ & LP & 4 & 135 & 2661 & $\mathbf{F}$ & & 1081 & \\
\hline 5 & 183 & 569 & $M$ & & 0928 & & 5 & 136 & $\begin{array}{lll}25 & 1 & 1\end{array}$ & $M$ & & 0998 & \\
\hline 6 & 114 & 171 & $F$ & & 1154 & & 6 & 132 & 259 & $F$ & & 1126 & \\
\hline 7 & 124 & 208 & $F$ & & 1091 & & 7 & 133 & \begin{tabular}{ll|l}
27 & 3 & 1
\end{tabular} & $M$ & & 116 & \\
\hline 8 & 146 & 374 & $\sqrt{F}$ & & 1202 & & 8 & 133 & 249 & $M$ & & 1058 & \\
\hline 9 & 128 & 246 & $F$ & & 9173 & & 9 & 142 & 325 & $F$ & & 1135 & \\
\hline 10 & 124 & 212 & $F$ & & \begin{tabular}{|lll|l|}
1 & 1 & 12 \\
\end{tabular} & & 10 & 107 & 124 & $\bar{F}$ & & 1012 & \\
\hline 11 & $\begin{array}{ll}163 \\
\end{array}$ & 438 & $F$ & & $10011 / L$ & LP & 11 & 137 & 276 & $F$ & & 1073 & \\
\hline 12 & 123 & 202 & $M$ & & 1086 & & 12 & 129 & 2321 & $M$ & & 1034 & \\
\hline 13 & 126 & 236 & $F$ & & $\begin{array}{lll}1 & 18 \\
\end{array}$ & & 13 & 134 & 2621 & $F$ & & 10891 & $L P$ \\
\hline 14 & 138 & 294 & $F$ & & 1.119 & & 14 & 113 & 156 & $F$ & & 1081 & \\
\hline 15 & 140 & 321 & F & & 117 & LP & 15 & 131 & 221 & $M$ & & 0.979 & \\
\hline Ave & 140 & 324 & & & $\begin{array}{lll}1 & 124 \\
\end{array}$ & & Ave. & 133 & 258 & & & 1063 & \\
\hline SO & 20 & 129 & & & $008_{1}$ & & 50 & 12 & 6.7 & & & $\begin{array}{l}0052 \\
\end{array}$ & \\
\hline$\Phi$ & 5 & 33 & & & 0021 & & $S E$ & 3 & \begin{tabular}{|r|}
17 \\
\end{tabular} & & & \begin{tabular}{|ll|l|l|l|l|l|l|l|} 
& 014 \\
\end{tabular} & \\
\hline Fish & $\mathrm{FL} \quad \mathrm{mm}$ & Wt (g) & $\operatorname{sen}$ & Hot & Cond & Other & Fish & $\mathrm{FL}$ (mnv & Wi (a) & Sex & $\mathrm{HCl}$ & Cond & Other \\
\hline 3.6189 & Group II & Awy 13 & temp & $p=45$ & & & $3,6 / 89$ & Group II F & Rwy 13 & temp & $p=45$ & & \\
\hline 1 & 135 & 26 & & 40 & 1057 & & 1 & 116 & 169 & $\mathrm{ML}$ & & 10831 & \\
\hline 2 & 138 & 277 & & 49 & 1054 & & 21 & $\therefore 2$ & 198 & $\mathrm{~F}$ & & 1146 & \\
\hline 3 & 143 & 296 & $F$ & 45 & 1012 & & 3 & 117 & 19 & $\bar{F}$ & & \begin{tabular}{ll|l|}
1186 \\
\end{tabular} & \\
\hline 4 & 122 & 186 & $M$ & 40 & 1024 & & 4 & 127 & 2091 & $\mathbf{F}$ & & 102 & \\
\hline 5 & 135 & 268 & $M$ & 46 & 1089 & & 5 & 129 & 223 & $F$ & & $\begin{array}{lll} & 0 & 39 \\
\end{array}$ & \\
\hline 6 & 127 & 233 & $F$ & 45 & $\begin{array}{lll}1 & 137 \\
\end{array}$ & & 6 & 128 & 216 & $\mathbf{F}$ & & $\begin{array}{ll}1 & 03 \\
\end{array}$ & \\
\hline 7 & 122 & 193 & $F$ & 48 & 1063 & & 7 & 125 & 22.9 & $\bar{M}$ & & 1172 & \\
\hline 8 & 114 & 166 & $E$ & $M$ & 112 & & 8 & 140 & 30 & $M$ & & 1093 & \\
\hline & 133 & 261 & $\bar{F}$ & 46 & 1109 & & 9] & 1.93 & 323 & sd & & 1177 & LP \\
\hline & 130 & 50 & & 51 & $115 ?$ & & & 140 & 289 & $F$ & & 1.053 & \\
\hline 11 & 1.211 & $.77 \mathrm{~J}$ & UTm & -1 & $.1 . \Omega \ldots 0274$ & & 1011 & 142 & 2832 & 4 & & $=1132$ & \\
\hline 121 & 135 & 26.6 & & 411 & 1081 & & 12 & 120 & 18 이 & $r \quad$ & & To881 & \\
\hline 13 & 122 & 17.7 & ind & 44 & 0975 & & .13 & .125 & 213 & $F$ & & 1091 & \\
\hline 14 & 120 & 182 & $F$ & 47 & 1053 & & 14 & 132 & 225 & $\mathbf{F}$ & & 0978 & \\
\hline 15 & & & & & & & 15 & 123 & 201 & $M$ & & 1075 & \\
\hline Ave & 126 & 219 & & 45 & 1061 & & Ave & $12 \theta$ & 233 & & & 1091 & \\
\hline SD & 12 & 59 & & & $\$ 10062 \mid$ & & SO & 2 & 51 & $I$ & 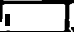 & 0062 & \\
\hline $\bar{I}$ & 3 & 16 & & & \begin{tabular}{l|ll}
1 & 0171 \\
\end{tabular} & & SE & & 131 & & & $\begin{array}{llll} & 0161 \\
\end{array}$ & \\
\hline
\end{tabular}




\begin{tabular}{|c|c|c|c|c|c|c|c|c|c|c|c|c|c|}
\hline Fish & $F L<\mathrm{mm}$ & $w_{t}$ (a) & $\operatorname{sex}$ & Het & Cond & Other & Fish & $F L<m r$ & wt $(g)$ & Sex & Het & Cond & Other \\
\hline 32189 & Group 1 & Awy 11 & 910 & am le & $\mathrm{emp}=8$ & & 3.21 .89 & Group II & Rwy 11 & temp & $p=8$ & & subarp \\
\hline 1 & 124 & 199 & $\mathrm{~F}$ & & 1044 & & 9 & \begin{tabular}{|r|}
134 \\
\end{tabular} & \begin{tabular}{|l|}
259 \\
\end{tabular} & $F$ & 29 & 1076 & 1 \\
\hline 2 & 126 & 25 & $F$ & & 125 & & 2 & 130 & 232 & $F$ & 31 & 1056 & 1 \\
\hline 3 & 135 & $\begin{array}{lll}26 & 4 \\
\end{array}$ & $F$ & & 1073 & & 3 & 133 & 271 & $M$ & 25 & 1152 & 1 \\
\hline 4 & 135 & 28 & $M$ & & 1138 & & 4 & 124 & 218 & 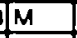 & 29 & $\begin{array}{lll}1 & 143 \\
\end{array}$ & 1 \\
\hline 5 & 139 & 292 & $F$ & & 1087 & & 5 & 135 & 26.3 & $M$ & 32 & 1069 & 1 \\
\hline 6 & 136 & 289 & $F$ & & 1149 & LLP & 6 & 142 & 303 & Md & 42 & 1058 & $1 \mathrm{Lm} \mathrm{LF}$ \\
\hline 7 & 143 & 326 & $M$ & & $\begin{array}{lll}1115 \\
\end{array}$ & & 7 & 136 & 263 & $M$ & 31 & 1046 & 1 \\
\hline 8 & 136 & 289 & Md & & 1149 & & 8 & 135 & 273 & $M$ & 36 & $\begin{array}{ll}1 & 11 \\
\end{array}$ & 2 \\
\hline 9 & 125 & 219 & $F$ & & 1121 & & 9 & 130 & 269 & $F$ & 32 & 1224 & 2 \\
\hline 10 & 146 & 365 & $F$ & & 1173 & & 10 & 130 & 243 & 3 & 26 & 1100 & 2 \\
\hline 11 & 147 & 354 & $F$ & & 1114 & & 11 & 137 & 279 & $F$ & 39 & 1085 & 2 \\
\hline 12 & 146 & 341 & $M$ & & 1096 & & 12 & 140 & 33 & $F$ & 31 & 1203 & 2 \\
\hline 13 & 160 & 465 & $F$ & & $\begin{array}{ll}1135 \\
\end{array}$ & & 13 & 131 & 251 & IF & 32 & 1117 & 2 \\
\hline 14 & 148 & 382 & $F$ & & 1178 & & 14 & 141 & 319 & $F$ & 39 & 1138 & 2 \\
\hline 15 & & & & & & & 15 & 146 & 356 & $F$ & 37 & 1144 & 2 \\
\hline Ave & 139 & 308 & & & 113 & & Ave & 135 & 275 & & 33 & 1115 & \\
\hline$S D$ & 10 & 7 & & & 0051 & & 50 & 6 & 37 & & 5 & 0053 & \\
\hline$\Phi$ & 3 & 19 & & & 0014 & & SE & 1 & 1 & & 1 & 00014 & \\
\hline Fish & $F L,(\mathrm{~mm}$ & WI $(9)$ & Sex & HCt & Cond & Other & Fish & $F L \quad(m)$ & wt $(g)$ & Sex & Het & Cond & Other \\
\hline $3.21 \cdot 89$ & Group III & Awy 11 & temp: & $y=8$ & & & $3: 21: 89$ & Group 1 & $A_{\text {wy }} 13$ & 1250 & $0 \mathrm{pm}$ & temp $=8$ & \\
\hline 1 & \begin{tabular}{|r|}
121 \\
\end{tabular} & 20 & $F$ & & 1129 & $L m$ & $1 \mid$ & \begin{tabular}{|l|}
121 \\
\end{tabular} & 208 & $M$ & & \begin{tabular}{|l|l|}
174 \\
\end{tabular} & \\
\hline 2 & 128 & 241 & $M$ & & 1149 & & 2 & 122 & 204 & $M$ & & 1123 & \\
\hline 3 & 120 & 195 & $\mathrm{~F}$ & & 1128 & & 3 & 130 & 252 & $F$ & & 1147 & \\
\hline 4 & 137 & 296 & $F$ & & 1151 & & 4 & 132 & 259 & $M$ & & 1126 & \\
\hline 5 & 147 & 353 & $M$ & & 1111 & & 5 & 131 & $25 \mathrm{~g}$ & MAd & & 1152 & $L p$ \\
\hline 6. & 132 & 261 & $F$ & & 1135 & & 6 & 143 & 333 & $F$ & & 7139 & \\
\hline 7 & 132 & 254 & $\mathrm{Md}$ & & 1104 & & 7 & 141 & $\begin{array}{lll}31 & 1 \\
\end{array}$ & $M$ & & $\begin{array}{ll}1 & 109 \\
\end{array}$ & \\
\hline 8. & 115 & 166 & $F$ & & 1091 & & 8 & 148 & 384 & $M$ & & 1046 & \\
\hline 9 & 138 & 292 & $\mathbf{F}$ & & 11111 & & 9 & 137 & 269 & $F$ & & 1046 & \\
\hline 10 & 119 & 197 & $M$ & & 1169 & & 10 & 137 & 2781 & Md & & 1081 & \\
\hline 111 & $\therefore$ 다의 & 176 & $F$ & & 1071 & & 11 & 149 & 347 & $M$ & & 1049 & \\
\hline 121 & 1291 & 245 & $F$ & & 1146 & & 12 & 160 & 43 & $F$ & & $\begin{array}{ll}105 \\
\end{array}$ & \\
\hline 13 & 130 & 246 & $\mathbf{F}$ & & 1138 & & 13 & 167 & 485 & $F$ & & 1041 & \\
\hline 14 & 131 & 25 & $\mathbf{F}$ & & 1112 & & 14 & 190 & 7551 & $M d$ & & 1101 & \\
\hline 15 & 126 & 223 & $M$ & & 1115 & & 15 & 184 & 6291 & Add & & 101 & \\
\hline Ave & 128 & 24 & & & 1124 & & Ave & 146 & 36 & & & 1093 & \\
\hline So & 9 & 5 & & & 0025 & & 50 & 21 & 158 & & & 005 & \\
\hline SE & 2 & 12 & & & 0007 & & $\boldsymbol{F}$ & 5 & 41 & & & $\begin{array}{lllll}0 & 0 & 13\end{array}$ & \\
\hline Fish & $F L \quad(\mathrm{~mm}$ & Wt (g) & Sex & $\mathrm{HCl}$ & Cond & Other & Fish & FL $\mathrm{cmr}$ & wi gal & Sex & Het & Cond & Other \\
\hline 3.21189 & Group II & Rwy 13 & temp & $0=8$ & & subgrp & $3: 21: 89$ & Group II & Rwy 13: & lemp & $0=8$ & & \\
\hline 1 & \begin{tabular}{|r|}
119 \\
\end{tabular} & 206 & $F$ & 36 & 1222 & 1 & 1 & 126 & \begin{tabular}{|l|}
22 \\
\end{tabular} & $F$ & & $\begin{array}{ll}11 \\
\end{array}$ & \\
\hline 2 & 124 & 207 & $F$ & 33 & 1086 & 1 & 2 & 144 & 324 & $M$ & & 1085 & \\
\hline 3 & 140 & 28.1 & Md & 35 & $\begin{array}{lll}1 & 024 \\
\end{array}$ & 1 & 3 & 128 & 221 & $\mathbf{F}$ & & 1054 & \\
\hline 4 & 117 & 177 & $F$ & 34 & 1105 & 1 & 4 & 134 & 267 & $M$ & & $\begin{array}{llll}1 & 1 & 1\end{array}$ & \\
\hline 5 & 130 & 25 & $M$ & 39 & 1.138 & 1 & 5 & 125 & 216 & $F$ & & 1106 & \\
\hline 6 & 140 & 30 & $F$ & 38 & $\begin{array}{lll}1 & 093 \\
\end{array}$ & 1 & 6 & 184 & 628 & $M$ & & 1008 & \\
\hline 7 & 137 & 296 & $M$ & 40 & 1151 & 1 & 7 & 137 & 261 & $F$ & & 1015 & \\
\hline 8 & 143 & 31 & $\mathbf{F}$ & 31 & 1.06 & 1 & 8 & 142 & 305 & $F$ & & 1065 & \\
\hline 9 & 149 & 382 & $\mathbf{M}$ & 41 & 1155 & 1 & 9 & 119 & 176 & $\mathbf{F}$ & & 1044 & \\
\hline 10 & 113 & 148 & $\mathbf{F}$ & 32 & 1026 & 2 & 10 & 138 & 301 & $M$ & & 1142 & \\
\hline 11 & 125 & 207 & $\bar{M}$ & 33 & 1.123 & 2 & 11 & 129 & 228 & $M$ & & 1062 & $L P$ \\
\hline 12 & 127 & 23 & $\mathbf{M}$ & 31 & $\begin{array}{lll}1 & 123 \\
\end{array}$ & 2 & 12 & 153 & 37 & Md & & 1.033 & \\
\hline 13 & 133 & 24.5 & $\mathbf{F}$ & 37 & 1041 & 2 & 13 & 123 & 199 & $\mathbf{F}$ & & 1069 & \\
\hline 14 & 144 & 33 & $\mathbf{F}$ & 33 & 1.105 & 2 & 14 & 133 & 264 & $\mathbf{F}$ & & $\begin{array}{lll}1 & 122 \\
\end{array}$ & \\
\hline 15 & 143 & 335 & $M$ & 38 & 1.146 & 2 & 15 & 119 & 187 & $\mathbf{M}$ & & $\begin{array}{lll}1 & 11 \\
\end{array}$ & \\
\hline Ave & 132 & 26 & & 35 & 1.107 & & Ave & 136 & 278 & & & 1073 & \\
\hline SO & 11 & 66 & & 31 & 0054 & & SO & 16 & 111 & & & 004 & \\
\hline$S$ & 3 & 17 & & 1 & $\begin{array}{lll}0 & 0141 \\
\end{array}$ & & 15 & 4 & & & & $\begin{array}{llll}0 & 0 & 11\end{array}$ & \\
\hline
\end{tabular}




\begin{tabular}{|c|c|c|c|c|c|c|c|c|c|c|c|c|c|}
\hline Fish & FL $(\mathrm{mn}$ & Wt (g) & $\operatorname{sex}$ & $\mathrm{HCt}$ & Cond & Other & Fish & FL $(m n$ & WI lal & $\operatorname{sen} x$ & $\mathrm{HCt}$ & Cond & Other \\
\hline $4: 3.89$ & Group 1 & Awy 11 & 1110 & $\mathrm{am}$ & $\operatorname{lemp}=6$ & & 4.389 & Group II & Rwy 11 & 1110 & $\mathrm{am}$ & temp $=6$ & \\
\hline 1 & 120 & 184 & $F$ & & 1065 & & 1 & \begin{tabular}{|l|}
139 \\
\end{tabular} & 306 & $F$ & 32 & 1139 & \\
\hline 2 & 123 & 214 & $F$ & & 115 & & 2 & 139 & 323 & $F$ & 32 & 1203 & \\
\hline 3 & 130 & 255 & $M$ & & 1161 & & 3 & 132 & 255 & $F$ & 33 & 1109 & \\
\hline 4 & 123 & 191 & $F$ & & 1026 & & 4 & 118 & 181 & $\mathrm{~F}$ & 34 & 1102 & \\
\hline 5 & 124 & 209 & $\bar{M}$ & & 1096 & & 5 & 137 & 299 & $M$ & 29 & 1163 & \\
\hline 6 & 133 & 256 & $\bar{M}$ & & 1088 & & 6 & 135 & 283 & $F$ & 35 & 115 & \\
\hline 7 & 136 & 286 & $F$ & & $\begin{array}{lll}137 \\
\end{array}$ & & 7 & 148 & 365 & $F$ & 48 & 1126 & \\
\hline 8 & 138 & 286 & $M$ & & 1088 & & 8 & 136 & 276 & $M$ & 34 & 1097 & \\
\hline 9 & 145 & 37 & $F$ & & 1214 & & 9 & 135 & 278 & F & $4 r$ & 113 & \\
\hline 10 & 140 & 33.1 & $M$ & & 1206 & & 10 & 149 & 35 & $\sqrt{M}$ & 33 & $\square 058$ & \\
\hline 11 & 149 & 438 & $\mathrm{Mp}$ & & 1324 & & 11 & 149 & 368 & $F$ & 29 & 1112 & \\
\hline 12 & 153 & 386 & $E$ & & -1078 & & 12 & 138 & 29,2 & $\sqrt{M}$ & 38 & 9111 & \\
\hline 13 & 155 & 405 & $M_{M}$ & & 1089 & & 13 & 130 & 252 & $F$ & 38 & $1 \cdot 9$ & \\
\hline 14 & 169 & 524 & $\mathbf{M}$ & & 1086 & & 14 & 137 & 294 & $M$ & 37 & 1143 & \\
\hline & 134 & 572 & $F$ & & -1086 & & & & 672 & 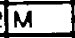 & 3.3 & 1152 & \\
\hline Ave & 141 & 327 & & & $\begin{array}{l}126 \\
\end{array}$ & & Ave & r & 32 & & 35 & 913 & \\
\hline SO & 17 & 12 & & & 0075 & & SO & 141 & 108 & & 5 & 0034 & \\
\hline SE & 4 & 31 & & & 0019 & & $S E$ & 3 & 3 & & 1 & $\begin{array}{lll}0 & 009 \\
\end{array}$ & \\
\hline Fish $*$ & $F L \quad(m)$ & Wt (g) & sex & HCt & Cond & Other & Fish & $\mathrm{FL}$ (m) & Wi $(g)$ & Sex & Hct & Cond & Other \\
\hline $43: 89$ & Group III & Rwy 11 & lemp: & $=6$ & & & 4389 & Group IV & Riwy 11 & tems & $p=6$ & & \\
\hline 1 & 153 & 441 & Md & & 1231 & & 1 & 143 & 3283 & $M$ & & 0968 & \\
\hline 2 & 128 & 237 & $\mathrm{M}^{-}$ & & 1.13 & & 2 & 148 & 365 & Mad & & 1126 & \\
\hline 3 & 144 & 365 & $\sqrt{\mathrm{Md}}$ & & 122 & & 3 & $1 \div 1$ & 217 & $\bar{r}$ & & 0947 & \\
\hline 4 & 118 & 195 & F & & 1187 & & 4 & 137 & 257 & $F$ & & 0999 & \\
\hline 5 & 146 & 355 & Mad & & 1141 & & 5 & 122 & 183 & $\sqrt[3]{M}$ & & 1008 & \\
\hline 6 & 125 & 223 & $F$ & & 1142 & & 6 & 136 & 251 & $F$ & & 0998 & \\
\hline 7 & 150 & 39 & $\sqrt{M}$ & & 1156 & & 7 & 145 & 327 & $F$ & & 1073 & \\
\hline 8 & 143 & 314 & $F$ & & .1074 & & 8 & 125 & $2 \pi 6$ & S & & 1106 & \\
\hline 9 & 157 & 415 & $F$ & 1 & 1072 & & 9 & 154 & 375 & Md & & 1027 & \\
\hline 10 & 117 & 193 & $M$ & & 1205 & & 10 & 138 & 258 & $M$ & & 0982 & \\
\hline 11 & 130 & 246 & $M$ & & $\begin{array}{ll}112 \\
\end{array}$ & & 11 & 165 & $4 \sqrt{2}$ & $\sqrt{M d}$ & & 1051 & \\
\hline & 135 & $=\overline{27}$ & $M$ & & 1097 & & 12 & 150 & 347 & $F$ & & 1028 & \\
\hline 13 & 137 & 30 & $F$ & & 1167 & & 13 & 145 & 322 & $P$ & & 1056 & \\
\hline 14 & 136 & 277 & $F=$ & & $\begin{array}{ll}1 & 101 \\
\end{array}$ & & 14 & 125 & 20 & $F$ & & 1024 & \\
\hline 13 & 1001 & 299 & $\mathrm{~F}$ & & 1138 & & 15 & 142 & 292 & 25 & & 1023 & \\
\hline ANE & 437 & 301 & & & 1146 & & 16 & 150 & 349 & $\underline{M}$ & & To34 & \\
\hline so & 12 & 78 & & & 005 & & 171 & 117 & 168 & $F$ & & 1049 & Deed \\
\hline $\bar{F}$ & 3 & 2 & & & $\begin{array}{lllll}0 & 0 & 13 & 1\end{array}$ & & 18 & 112 & 145 & $\widehat{F}$ & & 1032 & Dead \\
\hline & & & & & & & $9 \mathrm{9}$ & 131 & 272 & $\sqrt{F}$ & & 121 & Deand \\
\hline & & & & & & & 20 & 321 & 202 & F & & 114 & Dead \\
\hline & & & & & & & Ave & 137 & 278 & & & 1044 & \\
\hline & & & & & & & 50 & 14 & 81 & & & 0063 & \\
\hline & & & & & & & 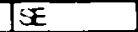 & 4 & 21 & & & $\begin{array}{llll}0 & 14 \\
\end{array}$ & \\
\hline Fish & $\mathrm{FL} \quad \mathrm{mm}$ & wi (a) & \begin{tabular}{|l|} 
Sex \\
\end{tabular} & HCt & Cond & Other & Fish & $\mathrm{FL}(\mathrm{mn}$ & Ifwe (g) & $\operatorname{sen}$ & HCt & Cond & Oiner \\
\hline $\begin{array}{l}4389 \\
\end{array}$ & Group I & Riwy 13 & 130 & $\mathrm{pm} \mathrm{te}$ & $\mathrm{emp}=6$ & & 4389 & 9 Group II & Rिy 13 & lemp & $p=6$ & & \\
\hline 1 & 119 & 195 & $M$ & & 11157 & & 1 & $1 \quad 131$ & 1241 & $F$ & 29 & 1072 & \\
\hline 2 & 118 & 164 & $M$ & & 0998 & & 2 & 125 & 235 & $\sqrt[F]{F}$ & 36 & 1203 & \\
\hline 3 & 132 & 249 & $M$ & & 1083 & & 3 & 134 & 269 & $F$ & 39 & 1118 & \\
\hline 4 & 120 & 184 & $M$ & & 1065 & & 4 & 136 & 30 & $\sqrt{M}$ & 34 & 1193 & \\
\hline 5 & 133 & 277 & $F$ & & 1177 & & 5 & 135 & 29 & $F$ & 36 & 1179 & \\
\hline 6 & 136 & 30 & $F$ & & 1193 & & 6 & 122 & 22 & $2 F$ & 30 & 1212 & \\
\hline 7 & 143 & 335 & $M$ & & 1146 & & 7 & 139 & 313 & 3 & 35 & 1165 & \\
\hline 8 & 142 & 33 & $M$ & & 1153 & & 8 & 141 & 322 & a & 39 & 1149 & cloudy pl \\
\hline 9 & 149 & 345 & $\bar{M}$ & & $1-0.31$ & & 9 & 145 & 325 & $5 \longdiv { M }$ & 31 & 1066 & \\
\hline 10 & 164 & 474 & $F$ & & $i 0751$ & & 10 & 158 & 401 & $M$ & 39 & 1017 & \\
\hline 11 & 148 & 361 & $\bar{M}$ & & 1114 & & 11 & 157 & 45 & $5 \longdiv { F }$ & 37 & 1163 & cloudy p \\
\hline 12 & 145 & 328 & $n$ & h & . 076 & & 12 & 132 & 264 & 1.5 & 40 & 1135 & \\
\hline 13 & 157 & 423 & $M$ & & 1043 & & 13 & 133 & 287 & $7 \mathrm{~F}$ & 34 & 122 & \\
\hline 14 & 182 & $\div 19$ & Nus & 1 & i 193 & & 14 & $\overline{135}$ & 261 & IF & A? & 1061 & \\
\hline & 182 & 63 & $F$ & & 1045 & & 15 & 150 & 394 & $\sqrt[F]{F}$ & 41 & 1038 & \\
\hline Are & 145 & 354 & & & 1107 & & Ave & 139 & 305 & & 36 & 1133 & \\
\hline 50 & 20 & -156 & & & 006 & & 150 & 11 & 66 & สा & 4 & 0067 & \\
\hline$E$ & 5 & & & & $\begin{array}{llll}0 & 0 & 15\end{array}$ & & $1 s$ & & 17 & & & 0017 & \\
\hline
\end{tabular}




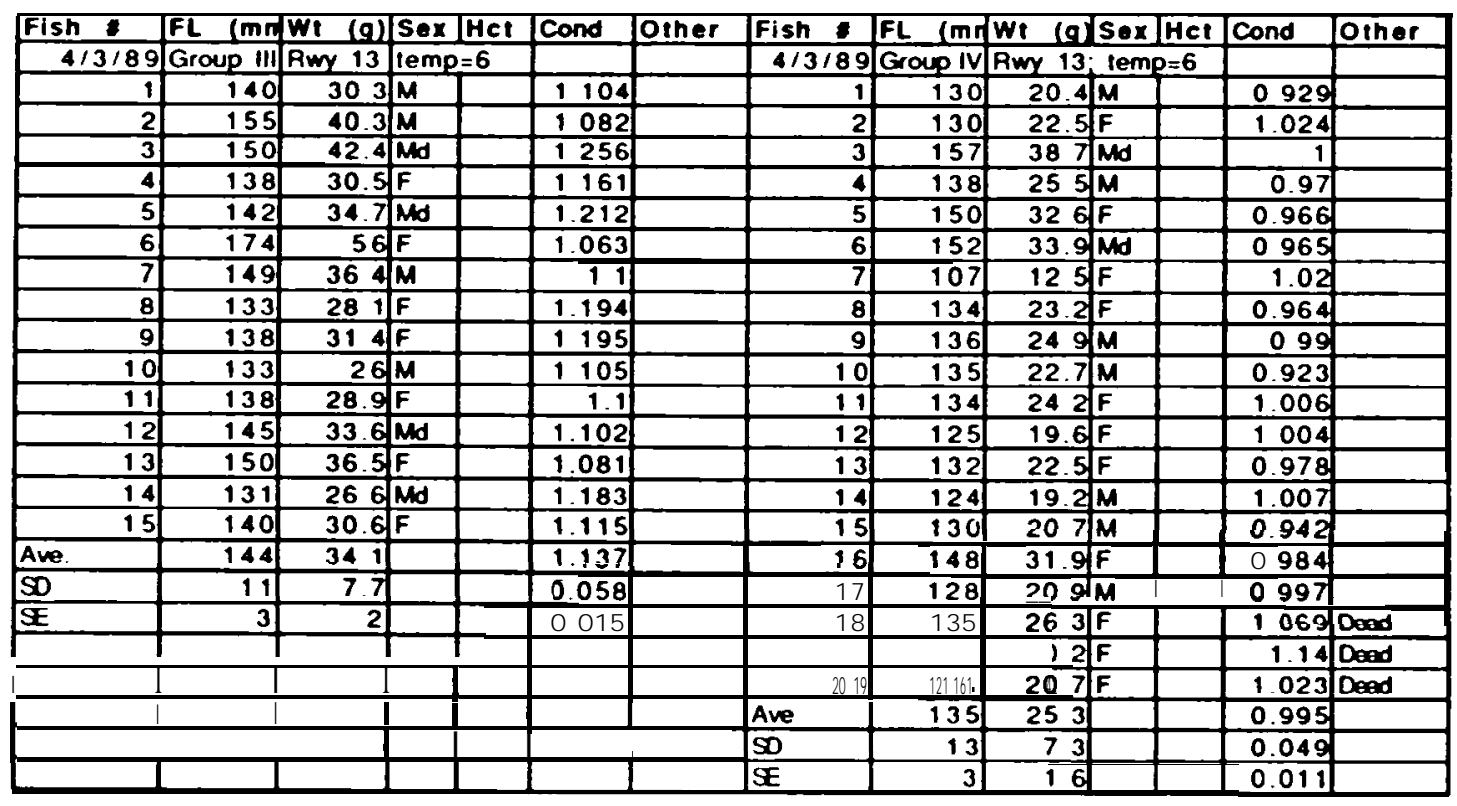




\begin{tabular}{|c|c|c|c|c|c|c|c|c|c|c|c|c|c|}
\hline \multicolumn{2}{|c|}{ Willamette } & \multicolumn{12}{|c|}{ IMd=developing male; Mp=fully developed, precoclour male; An=anemic } \\
\hline Lp=pale & \multirow{2}{*}{\multicolumn{2}{|c|}{$\begin{array}{l}\text { liver; } \mathrm{Lm}=\text { mottled } \\
\mathrm{FL}(\mathrm{mm} \text { ) } \mathrm{al}\end{array}$}} & \multirow{2}{*}{ Sex live } & \multicolumn{2}{|c|}{ er; $T=$ coded } & \multirow{2}{*}{\begin{tabular}{l|} 
wire tog; \\
Other
\end{tabular}} & B=branded & \multirow[b]{2}{*}{$(\mathrm{mm}$} & \multirow[b]{2}{*}{ Wi $(\mathrm{gl}$} & \multirow[b]{2}{*}{ Sex } & & & \\
\hline Fish $*$ F & & & & HCt & Cond & & & & & & Het & Cond & Other \\
\hline $320: 89 \mathrm{C}$ & Group 1 & Rwy 21A & $A$ (Apr & ril rel & $1130 \mathrm{am}$ & $\operatorname{temp}=4$ & $3: 20: 89$ & Group II & Awy 21 & A $(\mathrm{AP}$ & pril rel) & $\operatorname{temp}=4$ & Subgroup \\
\hline 1 & 136 & $285 \mid \mathrm{F}$ & $F$ & & 1133 & & 1 & 118 & 172 & $M$ & 33 & 1047 & 1 \\
\hline 2 & 135 & $4211 f$ & $F$ & & 1131 & & 2 & 118 & 173 & $M$ & 35 & 1.053 & ㄴ.P. Lm \\
\hline 3 & 121 & 19 & $\mathbf{F}$ & & 1073 & & 3 & 127 & 23 & $M$ & 30 & 1.123 & 1 \\
\hline 4 & 140 & 300 & $\bar{M}$ & & 1093 & & 4 & 128 & 212 & $\mathrm{M}$ & 32 & 1011 & Lordosis 21 \\
\hline 5 & 139 & 286 & $\bar{M}$ & & 1065 & & 5 & 128 & 23 & $F$ & 36 & 1097 & 1 \\
\hline$\overline{6}$ & 133 & 284 & & & 1207 & & 6 & 152 & 42 & $\mathrm{~F}^{-}$ & 341 & 1.1961 & 1 \\
\hline 7 & 135 & 275 & $\mathbf{F}$ & & 1118 & & 7 & 145 & 348 & $\bar{M}$ & 39 & $\begin{array}{lll}1441 \\
\end{array}$ & 1 \\
\hline 8 & 154 & 406 & $\mathbf{F}$ & & 1112 & & 8 & 168 & 499 & $F$ & 25 & 1.052 & 1 \\
\hline 9 & 151 & \begin{tabular}{l|l|}
405 \\
\end{tabular} & Md & & 1176 & & 9 & 180 & 612 & $F$ & 34 & 1049 & 1 \\
\hline 10 & 155 & 404 & Md & & 1085 & & 10 & 118 & 189 & $F$ & 30 & 115 & 2 \\
\hline 11 & 159 & 482 & Md & & 1199 & & 11 & 132 & 254 & $F$ & 31 & 1.104 & 2 \\
\hline 12 & 158 & 454 & $\bar{F}$ & & 1151 & & 12 & 167 & 514 & $\mathbf{M}$ & 29 & 1.04 & 2 \\
\hline 13 & 153 & 385 & $F$ & & 1075 & & 13 & 131 & 26 & $F$ & 33 & 1.157 & 2 \\
\hline 14 & 173 & 63 & Mad & & 1217 & & 14 & 148 & 353 & $\bar{M}$ & 32 & 1089 & 2 \\
\hline 15 & 180 & 647 & $F$ & & 1.109 & & 15 & 200 & 872 & $F$ & 31 & 109 & 2 \\
\hline Ave & 149 & 39 & & & $\begin{array}{ll}1 & 13 \\
\end{array}$ & & Ave & 144 & 356 & & 32 & 1098 & \\
\hline 50 & 16 & 129 & & & 0051 & & $S D$ & 25 & 198 & & 3 & 005 & \\
\hline$\underline{S E}$ & 4 & \begin{tabular}{|r|}
33 \\
\end{tabular} & & & \begin{tabular}{|l|l|}
0 & 013 \\
\end{tabular} & & $S$ & 6 & 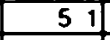 & & 1 & $\begin{array}{lllll}0 & 0 & 13 \\
\end{array}$ & \\
\hline Fish & FL $(\mathrm{mm}$ & We (a) & Sex & HCt & Cond & Other & \begin{tabular}{|l|l} 
Fish & \\
\end{tabular} & $\mathrm{FL} \quad \mathrm{mm}$ & Wi lg & sex & $\mathrm{HCl}$ & Cond & Other \\
\hline 320.89 & Group IIII & Rwy $21 \mathrm{~A}$ & (Ap & It rel & $\operatorname{temp}=4$ & & $4 / 5: 89$ & Group I & Rwy 21 & $A(A P$ & pril rel) & $900 \mathrm{am}$ & $\operatorname{temp}=8$ \\
\hline 1 & 133 & 25 & in & & 1092 & & 11 & 127 & 22 & $M$ & & \begin{tabular}{|l|}
1.108 \\
\end{tabular} & \\
\hline 2 & 134 & 268 & $M$ & & 1114 & & 2 & 136 & 291 & $F$ & & 1157 & \\
\hline 3 & 163 & 454 & $F$ & & 1048 & & 3 & 148 & 357 & $M$ & & 1101 & \\
\hline 4 & 143 & 3321 & $F$ & & 1135 & & 4 & 140 & 291 & $F$ & & 106 & \\
\hline 5 & 1431 & 3.2 & $\mathbf{F}$ & & 1094 & & 5 & 136 & 27 & $F$ & & 1073 & \\
\hline 6 & 180 & 654 & $F$ & & 1121 & & 6 & 142 & 318 & $F$ & & 1111 & \\
\hline 7 & 132 & 247 & $M$ & & 1074 & & 7 & 142 & 293 & $F$ & & 1023 & \\
\hline 8 & 183 & 667 & $M$ & & 1088 & & 8 & 146 & 338 & $F$ & & 1086 & \\
\hline 9 & 136 & 279 & $\mathbf{F}$ & & 1109 & & 9 & 146 & 329 & $M$ & & 1057 & \\
\hline 10 & 140 & 308 & $F$ & & 1122 & & 10 & 150 & 373 & $M$ & & $\begin{array}{ll}1105 \\
\end{array}$ & \\
\hline 11 & 133 & 2711 & $F$ & & 1152 & & 11 & 150 & 365 & $F$ & & 1081 & \\
\hline 12 & 176 & 599 & $M$ & & 1099 & & 12 & 173 & 606 & $M$ & & $\begin{array}{ll}117 \\
\end{array}$ & \\
\hline 13 & 135 & 279 & $F$ & & 1134 & & 13 & 170 & 543 & Md & & 1105 & \\
\hline 14 & 142 & 296 & $F$ & & 1034 & & 14 & 199 & 904 & $M$ & & 1147 & \\
\hline 15 & 185 & 7031 & $M$ & & 111 & & 15 & 192 & 82 & $F$ & & 1159 & \\
\hline Ave & 151 & 396 & & & 1102 & & Ave & 153 & 422 & & & 1.103 & \\
\hline 50 & 21 & 171 & & & 0032 & & 50 & 21 & 20.5 & & & 0042 & \\
\hline $\mathscr{E}$ & 5 & \begin{tabular}{|l|}
44 \\
\end{tabular} & & & 0008 & & SE & 5 & \begin{tabular}{|l|}
53 \\
\end{tabular} & & & \begin{tabular}{|l|}
0.011 \\
\end{tabular} & \\
\hline Fish $*$ F & FL $(\mathrm{mm}$ & wt $(g)$ & Sex & HCt & Cond & Other & Fish & FL $\quad(m n$ & wi cal & sex & Het & Cond & Olher \\
\hline 4.5189 & Group II & Rwy 21A & $A(A P$ & oril rell & $\operatorname{temp}=8$ & & 4,5189 & Group IIII & Rwy 21 & A $(A)$ & pril rel) & Lemp $=8$ & \\
\hline 1 & 148 & $\begin{array}{ll}353 \\
\end{array}$ & $F$ & 32 & 1089 & & \begin{tabular}{r|}
1 \\
\end{tabular} & 185 & 67 & $F$ & & 1.058 & \\
\hline 2 & 131 & 245 & & 28 & 109 & & 2 & 152 & 34 & $M$ & & 0968 & \\
\hline 3 & 161 & 467 & $M$ & 31 & 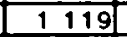 & & 3 & 158 & 476 & $F$ & & 1207 & \\
\hline 4 & 134 & 256 & $\bar{M}$ & 30 & 1064 & & 4 & 159 & $\begin{array}{lll}473 \\
\end{array}$ & Md & & 1177 & \\
\hline 5 & 155 & 428 & $\mathrm{~F}$ & 39 & $\begin{array}{ll}1149 \\
\end{array}$ & & 5 & 134 & 279 & $F$ & & 116 & \\
\hline 6 & 166 & 486 & $F$ & 35 & 1062 & & 6 & 159 & 45.3 & $F$ & & 1127 & Lm \\
\hline 7 & 142 & 305 & $F$ & 36 & 1065 & & 7 & 146 & 353 & $F$ & & 1134 & \\
\hline 8 & 156 & 43 & $M$ & 38 & 1.133 & & 8 & 160 & 451 & Md & & 1.101 & \\
\hline 9 & 155 & 415 & $F$ & 37 & 1.114 & & 9 & 140 & 29.4 & $M$ & & 1071 & \\
\hline 10 & 147 & 354 & $F$ & 36 & 1114 & & 10 & 117 & 173 & $F$ & & 1.08 & \\
\hline 11 & 188 & 752 & $\bar{M}$ & 40 & $1 \quad 132$ & & 11 & 132 & 27.1 & $F$ & & 1.178 & \\
\hline 12 & 187 & 734 & $\mathbf{F}$ & 41 & \begin{tabular}{lll|}
1 & 122 \\
\end{tabular} & & 12 & 154 & 39.9 & $F$ & & 1.092 & \\
\hline 13 & 187 & 748 & $\mathbf{F}$ & 32 & 1.144 & & 13 & 177 & 569 & $M$ & & 1026 & \\
\hline 14 & 154 & 401 & $M$ & 25 & 1098 & $L c t>2$ & 14 & 163 & 485 & $M$ & & 112 & \\
\hline 15 & 151 & 369 & $M$ & 31 & 1072 & & 15 & 138 & 278 & $F$ & & 1058 & \\
\hline Ave & 157 & 45 & & 34 & 1105 & & Ave & 152 & 398 & & & \begin{tabular}{l|l}
1.104 \\
\end{tabular} & \\
\hline $\mathrm{SO}$ & 18 & 167 & & 5 & \begin{tabular}{lll|}
0 & 03 \\
\end{tabular} & & SO & 18 & 131 & & & $\begin{array}{llll}0 & 064 \\
\end{array}$ & \\
\hline $\mathscr{E E}$ & 5 & 43 & & 1 & \begin{tabular}{lll|l}
0 & 0 & 08
\end{tabular} & & 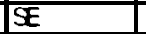 & \begin{tabular}{l|}
5 \\
\end{tabular} & \begin{tabular}{r|}
34 \\
\end{tabular} & & & $\begin{array}{llll}0 & 016\end{array}$ & \\
\hline
\end{tabular}




\begin{tabular}{|c|c|c|c|c|c|c|c|c|c|c|c|c|c|}
\hline Fish & $(\mathrm{mm}$ & $w_{t}$ & Sex & HCt & Cond & Other & Fish & $F L \quad(m m$ & Wt lal & Sex & Het & Cond & Other \\
\hline $4 / 5 / 89$ & Group IV & AwY 21 & $A(A D$ & rril rell. & $\operatorname{temp}=8$ & & $4 / 5 / 89$ & Group I & Rwy 21 & $B(M z$ & arel) & $11.20 \mathrm{an}$ & m tomp $=8$ \\
\hline 1 & 169 & \begin{tabular}{|l|}
551 \\
\end{tabular} & $M$ & & \begin{tabular}{|l|l|}
1142 \\
\end{tabular} & & 1 & 121 & 18 & $\mathbf{F}$ & & 1.016 & \\
\hline 2 & 144 & 303 & $\mathbf{F}$ & & 1105 & & 2 & 130 & 219 & $\mathbf{F}$ & & 0.997 & \\
\hline 3 & 175 & 58.4 & $\bar{M}$ & & 109 & & 3 & 145 & 341 & $\mathbf{F}$ & & 1.119 & \\
\hline 4 & 144 & 297 & $\mathbf{F}$ & & 0995 & & 4 & 139 & 284 & $\mathbf{F}$ & & 1.057 & \\
\hline 5 & 158 & 392 & $\mathbf{F}$ & & 0994 & & 5 & 138 & 28.6 & $\mathbf{M}$ & & 1081 & \\
\hline 6 & L6? & 42.1 & $\bar{F}$ & & 0.99 & & 6 & 147 & 369 & $\mathbf{M}$ & & 1162 & \\
\hline 7 & 121 & 16.9 & $\mathbf{M}$ & & 0954 & & 7 & 145 & 34.5 & $\mathbf{M}$ & & 1.132 & \\
\hline 8 & 180 & 60 & $F_{2}$ & & 1029 & & 8 & 133 & 27.9 & $F$ & & 1.186 & \\
\hline 9 & 153 & 365 & $F^{-}$ & & 10191 & & 9 & 156 & 43,8 & $\mathbf{F}$ & & 1.154 & \\
\hline 10 & 148 & 34 & Md. & & 1.049 & & 10 & 150 & $\begin{array}{lll}36 & 1 \\
\end{array}$ & $F$ & & 1.07 & \\
\hline 11 & 163 & 467 & $F$ & & $1.0781^{\circ}$ & & 11 & 142 & 319 & $F$ & & 1114 & \\
\hline 12 & $15 \mathrm{G}$ & 387 & $\mathbf{M}$ & & 1.039 & & 12 & 158 & 41.7 & $F$ & & 1.057 & \\
\hline 13 & 159 & 40.2 & $\mathbf{M}$ & & 1 & & 13 & 156 & 458 & $F$ & & 1.206 & \\
\hline 14 & 154 & 384 & $F$ & & 1.051 & & 14 & 171 & 56.8 & $\bar{M}$ & & 1.136 & \\
\hline 15 & 155 & 377 & $\mathbf{M}$ & & 1012 & & 15 & 186 & 73.8 & Md & & 1147 & \\
\hline 16 & 140 & 276 & $F$ & & 1.006 & & Ave. & 148 & 37.3 & & & 1109 & \\
\hline 17 & 144 & 304 & $\mathbf{M}$ & & 1.018 & & 50 & 16 & 14 & & & 0061 & \\
\hline 18 & 153 & $\begin{array}{lll}36 & 4 \\
\end{array}$ & $\mathbf{M}$ & & 1.016 & & $\mathscr{S}$ & 4 & 36 & & & 0016 & \\
\hline 19 & 153 & 394 & Md & & 11 & & & & & & & & \\
\hline 20 & 132 & 22.2 & $\mathbf{F}$ & & 0.965 & & & & & & & & \\
\hline Ave. & 153 & 38 & & & 1028 & & & & & & & & \\
\hline SO & 14 & 11 & & & 00046 & & & & & & & & \\
\hline$\Phi$ & 3 & 25 & & & $\begin{array}{llll}0 & 0 & 1 \\
\end{array}$ & & & & & & & & \\
\hline Fish & $(\mathrm{mm}$ & wt $(g)$ & Sex & HCt & Cond & Other & Fish & $\mathrm{FL} \quad(\mathrm{mm}$ & Wt lal & Sex & $\mathrm{HCt}$ & Cond & Other \\
\hline $4 / 5 / 89$ & Group II & AwY $21 E$ & $\mathrm{~B}$ (Ma & (y ref ) & $\operatorname{Lemp}=8$ & & $4 / 5 / 89$ & Group III & Rwy 21 & $\mathrm{~B} / \mathrm{Mz}$ & ay rel $)$ & $1 e m p=8$ & \\
\hline 1 & 135 & 25.1 & F & 29 & \begin{tabular}{|l|}
1.02 \\
\end{tabular} & subgrp 1 & 1 & 146 & 352 & $\bar{F}$ & & 1.131 & \\
\hline 2 & 136 & 28.5 & $\mathbf{M}$ & 30 & 1.133 & $\begin{array}{r}1 \\
\end{array}$ & 2 & 149 & 35 & $\mathbf{M}$ & & 1.058 & \\
\hline 3 & 127 & 219 & $\bar{M}$ & 33 & 1.069 & 1 & 3 & 147 & 37.1 & $\bar{M}$ & & 1.168 & \\
\hline 4 & 140 & 29.2 & $M$ & 33 & 1.064 & 1 & 4 & 138 & 27.7 & $\mathbf{F}$ & & 1.054 & \\
\hline 5 & 135 & 29.1 & $F$ & 35 & 1.183 & 1 & 5 & 146 & 32.3 & $M$ & & 1.038 & \\
\hline 6 & 137 & 28.2 & $\bar{M}$ & 37 & 1097 & 1 & 6 & 157 & 40.8 & $\mathbf{F}$ & & 1.054 & \\
\hline 7 & 126 & 23.1 & $\bar{M}$ & 33 & 1.155 & 1 & 7 & 141 & 30 & $\mathbf{F}$ & & 107 & $\mathrm{Lm}$ \\
\hline 8 & 143 & 30.4 & $M$ & 38 & $\begin{array}{lll}1 & 0 & 4\end{array}$ & 1 & 8 & 174 & 558 & $\mathbf{F}$ & & 1.059 & \\
\hline 9 & 161 & 47.5 & $M P$ & 33 & 1.1381 & 1 & 9 & 1211 & 19.5 & $\bar{M}$ & & 1.101 & \\
\hline 10 & 163 & 46.3 & $M$ & 341 & 10691 & 1 & 10 & 165 & 507 & $M d$ & & 1.129 & \\
\hline 11 & 183 & 70.9 & $M$ & 24 & 1157 & 2 & 11 & 129 & 241 & $F$ & & 1.123 & \\
\hline 12 & 197 & 84.5 & $F$ & 32 & 1105 & 2 & 12 & 168 & 559 & $F$ & & 1.179 & \\
\hline 13 & 167 & 53 & $M$ & 35 & 1138 & 2 & 13 & 161 & 468 & $M$ & & 1121 & \\
\hline 14 & 172 & 539 & $F$ & 32 & 1059 & 2 & 14 & 166 & 541 & Md & & $\begin{array}{lll}1 & 183 \\
\end{array}$ & \\
\hline 15 & 147 & 349 & $\bar{M}$ & 28 & 1099 & 2 & 15 & 145 & 332 & $F$ & & 1.089 & 1 eye \\
\hline Ave & 151 & 404 & & 32 & 1.1021 & & Ave. & 150 & 38.5 & & & 1.104 & \\
\hline SO & 21 & 1861 & & 4 & 0.0481 & & 50 & 15 & $\mid 11.7$ & & & 0.048 & \\
\hline $\mathscr{E}$ & C & 4.8 & & 11,1 & $n_{0} 012$ & & $\mathbf{S E}$ & 4 & & & & 0.013 & \\
\hline Fish & (mm & Wt (g) & $\operatorname{Sex}$ & HCt & Cond & Other & Fish & $F \mathrm{~L} \quad \mathrm{~mm}$ & Wi (g) & Sex & HCt & Cond & Other \\
\hline $4 / 5189$ & Group IV & Rwy 21E & $8(\mathrm{Ma}$ & (y) ret & $\operatorname{temp}=8$ & & $4 / 19 / 89$ & Group I & Rwy 21 & $B(M B$ & ay rell & $1.00 \mathrm{pm}$ & \\
\hline 1 & \begin{tabular}{|l|}
175 \\
\end{tabular} & 54.5 & Md & & 1.017 & & 1 & 148 & 34.4 & $M$ & & 1.061 & \\
\hline 2 & 173 & 521 & $F$ & & 1006 & & 2 & 132 & 28.6 & $M$ & & 1.243 & \\
\hline 3 & 128 & 207 & $\mathbf{M}$ & & 0987 & & 3 & 135 & 29 & $\sqrt{M}$ & & 1.179 & \\
\hline 4 & 135 & 27.1 & $M$ & & 1101 & & 4 & 149 & $\begin{array}{lll}36 & 1 \\
\end{array}$ & $\mathbf{M}$ & & 1.091 & \\
\hline 5 & 166 & 442 & $\bar{M}$ & & 0966 & & 5 & 136 & 272 & $F$ & & 1.081 & \\
\hline 6 & 140 & 293 & $\mathbf{F}$ & & 1068 & & 6 & 153 & 394 & $\bar{F}$ & & 11 & \\
\hline 7 & 143 & 279 & $\bar{M}$ & & 0954 & & 7 & 163 & 456 & $\bar{F}$ & & 1.053 & \\
\hline 8 & 133 & 25.4 & $\bar{M}$ & & 1.08 & & 8 & 140 & 30.8 & $\mathbf{F}$ & & 1.122 & \\
\hline 9 & 182 & 61.9 & $M$ & & 1027 & & 9 & 146 & 358 & $\mathbf{M}$ & & 115 & \\
\hline 10 & 138 & 27.3 & $F$ & & 1039 & & 10 & 158 & 469 & $\mathbf{F}$ & & 1.189 & \\
\hline 11 & 132 & 26.7 & $F$ & & 1.161 & & 11 & 178 & 63 & Md & & 1117 & \\
\hline 12 & 177 & 56.1 & $F$ & & 1012 & & 12 & 180 & 664 & $M$ & & 1139 & \\
\hline 13 & 182 & 634 & $M$ & & 1.052 & & 13 & 166 & 497 & $\mathbf{M}$ & & 1087 & \\
\hline 14 & 130 & 22 & $M$ & & 1001 & & 14 & 179 & 643 & $\mathbf{F}$ & & 1121 & \\
\hline 15 & 145 & 30.6 & $\mathbf{F}$ & & 1.004 & & 15 & 205 & 96 & $M$ & & 1114 & \\
\hline 16 & 149 & 31.1 & $M$ & & 094 & & Ave. & 158 & 462 & & & 1123 & \\
\hline 17 & 158 & 394 & $\bar{F}$ & & 0999 & & 50 & 21 & 19.1 & & & 0051 & \\
\hline 18 & 144 & 33 & $M$ & & 1105 & & $\Phi$ & 5 & 49 & & & 0013 & \\
\hline 19 & 155 & 386 & $F$ & & 1037 & & & & & & & & \\
\hline 20 & 161 & 477 & $M$ & & $\begin{array}{lll}1 & 143 \\
\end{array}$ & & & & & & & & \\
\hline Ave & 152 & 38 & & & 1035 & & & & & & & & \\
\hline SO & 18 & 136 & & & 006 & & & & & & & & \\
\hline $\mathscr{S E}$ & 4 & 3 & & & 0013 & & & & & & & & \\
\hline
\end{tabular}




\begin{tabular}{|c|c|c|c|c|c|c|c|c|c|c|c|c|c|}
\hline Fish & $\mathrm{mm}$ & dwt (a) & Sex & Het & Cond & Other & Fish & FL $(m n$ & Wt $(g)$ & Sex & HCt & Cond & Other \\
\hline $4 / 19 / 89$ & Group II & Rwy 21E & $B(M$ & (y ret) & & & $4 / 19 / 89$ & Group III & Awy 218 & $B(M$ & ay rel.) & & \\
\hline 1 & 140 & \begin{tabular}{|l|}
29.3 \\
\end{tabular} & $\mathbf{F}$ & & 1068 & subgre 1 & 1 & 148 & 34.7 & $F$ & & 1.07 & \\
\hline 2 & 136 & 28.3 & $\mathbf{F}$ & 36 & 1125 & 1 & 2 & 151 & 389 & $\mathbf{F}$ & & 1.13 & \\
\hline 3 & 144 & 32.6 & $F$ & 28 & 1.092 & 1 & 3 & 159 & 451 & $M$ & & 1.119 & \\
\hline 4 & 165 & 50.7 & $F$ & 43 & 1129 & 1 & 4 & 171 & 60 & $\mathbf{F}$ & & 12 & \\
\hline 5 & 163 & 46.7 & $F$ & 42 & 1078 & $\overline{1}$ & 5 & 199 & 915 & $\bar{F}$ & & 1.161 & \\
\hline 6 & 194 & 81.9 & $M$ & 36 & 1122 & 1 & 6 & 137 & 298 & $\mathbf{F}$ & & 1.159 & \\
\hline 7 & 188 & 79.3 & $\bar{F}$ & 40 & 1193 & 1 & 7 & 191 & 84.5 & $\bar{M}$ & & 1.213 & \\
\hline 8 & 142 & 33 & $\bar{M}$ & 32 & 1153 & 2 & 8 & 162 & 47 & $\mathbf{F}$ & & 1.105 & \\
\hline 9 & 145 & 352 & $M$ & 30 & $1 \quad 155$ & 2 & 9 & 190 & 78.6 & $F$ & & 1.146 & \\
\hline 10 & 163 & 47.7 & $M$ & 36 & 1101 & -2 & 10 & 152 & 39.8 & $\bar{F}$ & & 1133 & \\
\hline 11 & 163 & 492 & $F$ & 41 & 1136 & $\overline{2}$ & 11 & 140 & 288 & $F$ & & 1.05 & \\
\hline 12 & 165 & 50.2 & $F$ & 37 & $\begin{array}{llll} & 1 & 18 \\
\end{array}$ & 2 & 12 & 158 & 47.11 & $F$ & & 1.194 & \\
\hline 13 & 159 & 45.2 & $M$ & 45 & 1.124 & 2 & 13 & 148 & 36.7 & F & & 1.132 & \\
\hline 14 & 187 & 73 & $F$ & 38 & 1116 & 2 & 14 & 189 & 811 & $\sqrt{M d}$ & & 12 & \\
\hline 15 & 197 & 92.3 & $\sqrt{M}$ & 34 & 1207 & 2 & 15 & 175 & 708 & $\overline{\mathbf{M d}}$ & & 1.321 & \\
\hline Ave & 163 & 51.6 & & 37 & \begin{tabular}{ll|}
1 & 128 \\
\end{tabular} & & Ave & 164 & 543 & & & 1.156 & \\
\hline SO & 20 & 20.5 & & 5 & $\begin{array}{lll}0 & 038\end{array}$ & & SO & 201 & 21.5 & & & 0.066 & \\
\hline 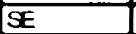 & 5 & 5.3 & & 1 & 0011 & & $\mathbf{x}$ & 5) & 56 & & & 0.017 & \\
\hline Fish $:$ & $\mathrm{smm}$ & wi $(g)$ & $\operatorname{sex}$ & HCt & Cond & Other & Fish 1 & $F L \quad(\mathrm{~mm}$ & Wt (g) & Sex & HCt & Cond & Other \\
\hline $5 / 4 / 89$ & Group I & Rwy 218 & $\mathbf{B}(\mathbf{M}$ & yy ret) & $1020 \mathrm{am}$ & n temp $=10$ & $5 / 4 / 89$ & Group II & Rwy $21 E$ & $\mathrm{~B}(\mathrm{M}$ & ay rel) & $\operatorname{temp}=1$ & \\
\hline 1 & 144 & \begin{tabular}{|l|}
32.3 \\
\end{tabular} & $F$ & & 1082 & & 1 & 147 & 335 & $M$ & 42 & 1.055 & subgrp \\
\hline 2 & 145 & 32.4 & $M$ & & 1063 & & 2 & $1^{n}=1$ & 39.5 & $\sqrt{\mathbf{M}}$ & 38 & 1.061 & 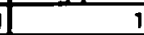 \\
\hline 3 & 141 & 302 & $\mathbf{F}$ & & 1077 & & 3 & $1=\overline{1}$ & 41.9 & $F$ & 47 & 1.083 & 1 \\
\hline 4 & 163 & 449 & $M$ & & 1037 & & 4 & 150 & 36.9 & $M$ & 41 & 1093 & 1 \\
\hline 5 & 147 & 33.5 & $F$ & & 1055 & & 5 & 151 & 3521 & $\bar{M}$ & 38 & 1.022 & 1 \\
\hline 6 & 157 & 404 & $\bar{M}$ & & 1044 & & 61 & 146 & 338 & $\mathbf{F}$ & 38 & 1.086 & 1 \\
\hline 7 & 140 & 302 & $F$ & & 1.101 & & 7 & 148 & 33.5 & $\mathbf{F}$ & 42 & 1.033 & 1 \\
\hline 8 & 145 & 33.3 & $\bar{F}$ & & 1.092 & & 8 & 190 & 76.5 & $\bar{F}$ & 37 & 1.115 & $\overline{2}$ \\
\hline 9 & 165 & 469 & $F$ & & 1044 & & 9 & 152 & 38.1, & $\bar{F}$ & 38 & 1085 & 2 \\
\hline 10 & 157 & 436 & $F$ & & 1.127 & & 10 & 192 & 77.10 & $\bar{M}$ & 41 & 1.089 & $\overline{2}$ \\
\hline 11 & 171 & 49.7 & $F$ & & 0994 & & 11 & 195 & 831 & $\mathbf{M}$ & 42 & 1.119 & 2 \\
\hline 12 & 155 & 39.6 & $M$ & & 1063 & & 12 & 154 & 398 & $M$ & 39 & 1.09 & 2 \\
\hline 13 & 185 & 66.9 & $F$ & & 1057 & & 13 & 170 & 53 & $F$ & 40 & 1079 & 2 \\
\hline 14 & 192 & 84.4 & $M$ & & 1.192 & & 14 & 174 & 64.81 & Md & 45 & 123 & 2 \\
\hline 15 & 212 & 101.5 & $M$ & & 1065 & & 15 & 170 & 50 & $M$ & 40 & 1018 & 2 \\
\hline Ave. & 161 & 47.3 & & & 1073 & & Ave. & 163 & 491 & & 41 & 1.084 & \\
\hline 50 & 21 & 21.1 & & & 0045 & & SD & 17 & 17.4 & & 3 & 0.051 & \\
\hline$\Phi$ & 5 & 55 & & & 0012 & & $\mathscr{E}$ & A & 4.6 & & 1 & 0.013 & \\
\hline Fish & $(\mathrm{mm}$ & Wi $(g)$ & $\operatorname{sex}$ & HCt & Cond & Other & Fish & FL $1 \mathrm{~mm}$ & wi la & sex & IHCt & Cond & Other \\
\hline $5 / 4 / 89$ & Group III & Rwy 218 & $B(M$ & y ret ) & $\operatorname{temp}=10$ & & $5 / 4 ; 89$ & Group IV & Rwy 21E & $\mathrm{B}(\mathrm{M}$ & ay rel.) & $\operatorname{temp}=10$ & \\
\hline 1 & 159 & 40 & $M$ & & \begin{tabular}{|l|}
0995 \\
\end{tabular} & & 1 & \begin{tabular}{|l|}
159 \\
\end{tabular} & 39 & $\mathbf{F}$ & & 0.97 & \\
\hline 2 & 140 & 29.6 & $\mathbf{F}$ & & 1079 & & 2 & 169 & 481 & $\bar{M}$ & & 0.994 & \\
\hline 3 & 210 & 111 & Mad & & 1199 & & 3 & 195 & 82.3 & $\mathbf{M}$ & & 1.11 & \\
\hline 4 & 162 & 458 & $F$ & & 1077 & & 4 & 170 & 501 & $\mathbf{F}$ & & 1.02 & \\
\hline 5 & 190 & 708 & $M$ & & 1032 & & 5 & 130 & 231 & $\mathbf{F}$ & & 1.051 & \\
\hline 6 & 153 & 34.4 & $F$ & & 096 & & 6 & 148 & 34.2 & $F$ & & 1.055 & \\
\hline 7 & 163 & 514 & $\bar{M}$ & & $\begin{array}{lll}187 \\
\end{array}$ & & 7 & 146 & 30.2 & $F$ & & 0.97 & \\
\hline 8 & 160 & 40 & $M$ & & 0977 & & 8 & 142 & 29.2 & $F$ & & 1.02 & \\
\hline 9 & 159 & 41.6 & $\mathbf{F}$ & & 1035 & & 9 & 174 & 54 & $\mathbf{M}$ & & 1.025 & \\
\hline 10 & 165 & 48 & $M$ & & 1069 & & 10 & 147 & 29.5 & $M$ & & 0929 & \\
\hline 11 & 160 & 44.2 & $F$ & & 1.079 & & 11 & 167 & 44.6 & $\mathbf{F}$ & & 0.958 & \\
\hline 12 & 170 & 51.6 & $M$ & & 105 & & 12 & 164 & 39.7 & $\bar{M}$ & & 09 & \\
\hline 13 & 171 & 61.8 & Md & & 1236 & & 13 & 146 & 31 & $\mathbf{F}$ & & 0.996 & \\
\hline 14 & 154 & 35 & $\bar{F}$ & & 0958 & & 14 & 139 & 28 & $M$ & & 1.043 & \\
\hline 15 & 182 & 668 & $F$ & & $\begin{array}{ll}108 \\
\end{array}$ & & 15 & 158 & 41.4 & $F$ & & 1.05 & \\
\hline Ave & 167 & 515 & & & 1069 & & 16 & 158 & 391 & $M$ & & 0.991 & \\
\hline SO & 17 & 203 & & & 0085 & & 17 & 157 & 42.5 & $M$ & & 1.098 & \\
\hline \multirow[t]{6}{*}{ IE } & 4 & 52 & & & 0022 & & 18 & 162 & 455 & $F$ & & 107 & \\
\hline & & & & & & & 19 & 195 & 769 & $M$ & & 1037 & \\
\hline & & & & & & & 20 & 139 & 263 & F & & 0979 & \\
\hline & & & & & & & Ave & 158 & 417 & & & 1.013 & \\
\hline & & & & & & & SO & -17 & 155 & & & 0054 & \\
\hline & & & & & & & $\mathbf{S E}$ & 4 & 35 & & & 0012 & \\
\hline
\end{tabular}


APPENDIX 2

Hatchery Information 


\section{DWORSHAK NATIONAL FISH HATCHERY}

Adult Spawners

Adult spring chinook salmon spawners (originally Rapid River stock, but also some Leavenworth, Little White Salmon, and Kooskia stocks) arrived at the hatchery from 22 May to 10 September 1987. Adults were held in adult holding ponds $(17 \times 75 \mathrm{ft}$, $7,500 \mathrm{cu} \mathrm{ft}$ water) with the upper one third shaded by a tarp and the remainder of the pond sprinkled to reduce stress. Inflowing water (1,645-2,110 gpm) was received from the North Fork of the Cleat-water and averaged IO- $13^{\circ} \mathrm{C}\left(50-55^{\circ} \mathrm{F}\right)$. From a total of 2,017 adults (60\% females, $40 \%$ males), 99 males and 220 females suffered prespawning mortality (15.8\%). Numbers and age classes included 1 -ocean, 25: 2-ocean. 1,604; and 3-ocean, 376. While held, adults received malachite green treatments ( $1 \mathrm{mg} / \mathrm{L}$ for 1 hour) daily (Monday through Friday) from 28 May to 17 August. Spawning (1,591 fish) was conducted from 24 August to 8 September 1987, using MS-222 (100 mg/L) buffered with sodium bicarbonate as an anesthetic.

There were six egg takes, numbered 1 through 6 , taken on $24,25,27$, and 31 August, and on 3 and 6 September, respectively (total eggs $=3,316,340$ ). Whenever possible, one male was used to fertilize the eggs from a single female. However, because of the sex ratio, males were often used twice. Tissue samples from males (kidney and spleen) and ovarian fluid from females were screened for IHN, BKD, VEN, Mvxobolus, etc. A total of 5.6\% (2.8\% males and $7.7 \%$ females) tested IHN positive. Less than $1 \%$ were grossly infected with BKD.

\section{Eggs}

Green eggs were placed in Heath trays (eggs from two females. 7,(0)(0)-7,500/tray) and water hardened for 30 minutes in $75 \mathrm{mg} / \mathrm{L}$ iodophore buffered with sodium bicarbonate. Eggs were incubated in ambient water $\left(10-13^{\circ} \mathrm{C} / 50-55^{\circ} \mathrm{F}\right)$, with those from IH. $-\left(7.7 C^{\circ}\right)$ 
and BKD-positive parents kept separate from the rest. At eye-up (92.95\%), eggs were shocked, salted, picked, and counted. Hatching was completed by mid-October.

\section{Early Rearing}

Fry were transferred from incubation (Heath) trays to inside nursery tanks during 9-27 November. Each tank (100 cu ft) received untreated river water (35-50 gpm) that averaged from $8.80 \mathrm{C}(47.80 \mathrm{~F})$ in November to a low of $4.20 \mathrm{C}(39.50 \mathrm{~F})$ in January and February, and $6.8^{\circ} \mathrm{C}\left(44.3^{\circ} \mathrm{F}\right)$ in April when the fish were transferred to outside raceways. Generally, fry from three Heath trays were placed in each tank $(19,000-30,000$ fish). Just prior to transfer outside (first part of April), fry averaged 247/lb (195-306/lb) and $61 \mathrm{~mm}(2.4 \mathrm{in})$ in length $(57-64 \mathrm{~mm}, 2.2-2.5 \mathrm{in})$. Fry from egg takes 3 and 4 , which were placed in the raceways monitored by this study (raceways 11, 12, 13. and 14), were from $210-245 / \mathrm{lb}$.

Biodiet Starter \#2 was used for initial feeding, which began shortly after transfer to the nursery in mid-November, and was fed until the fish reached 900/b. From this size until they reached 400/b, Biodiet Starter \#3 was used. Oregon Moist Pellets (OMP, 1/16) were fed starting at $400 / \mathrm{b}$. Fish were fed by hand, eight times daily. No antibiotics were used during nursery rearing. Tanks were cleaned daily by removing stand pipes and drawing water down about 50\%. Skylights in the roof provided some light during daytime, but the main lighting was from electric lights turned on at 7:30 a.m. and off at 4:00 p.m.

\section{Raceway Rearing}

In mid April, fish were transferred to standard $8 \times 80 \mathrm{ft}$ flow-through raceways $(1,320 \mathrm{cu} \mathrm{ft})$ with about $80,000 /$ raceway. Water was from the North Fork of the Clear-water River, with inflow rates of 562-636 gpm. Fish were divided in July, reducing 
pond densities (see the following table). Water levels were lowered once each week while ponds were cleaned. In addition, ponds were occasionally flushed and end screens cleaned. Some fish in ponds 14-17 were tagged with coded wire tags and freeze branded in December 1988. Some fish in ponds 13 and 14 (pond 13 was monitored in this study) received tags with code 05-40-15 (67,920) and some were branded (22,210; RD7H-3) on 7 December 1988. Fish were fed OMP, size 1/16, from 400 to 150/b; 3/32 from 150 to $40 / \mathrm{b}$; and $1 / 8$ from $40 / \mathrm{b}$ to release. Other information on rearing densities, feeding, and growth is found in the following table:

Averages for all production fish

\begin{tabular}{|c|c|c|c|c|c|c|c|c|c|c|c|}
\hline $\begin{array}{c}\text { Year } \\
\& \\
\text { Month }\end{array}$ & $\begin{array}{l}\text { Fish/ } \\
\text { pond }\end{array}$ & Fish/lb & $\begin{array}{l}W t \\
(g)\end{array}$ & $\begin{array}{l}\text { Lbs } \\
\text { fish/ } \\
\text { pond }\end{array}$ & $\begin{array}{r}\mathrm{FI} \\
\text { (in) } \\
\end{array}$ & $\begin{aligned} \begin{array}{r}\mathrm{Fl} \\
(\mathrm{m}\end{array} \\
\end{aligned}$ & $\begin{array}{l}\text { Density } t \\
\text { ) Index }\end{array}$ & $\begin{array}{l}\text { Water } \\
\text { e m p. } \\
\left({ }^{\circ} \mathrm{F} / \mathrm{C}\right)\end{array}$ & $\begin{array}{l}\text { Food } \\
\text { rate } \\
\text { (\%owt } \\
\text { day) }\end{array}$ & $\begin{array}{l}\text { Food } \\
\text { conver. } \\
\text { (food/ } \\
\text { o, gain) }\end{array}$ & $\begin{array}{l}\text { Mort. } \\
\text { (iir) }\end{array}$ \\
\hline \multicolumn{12}{|c|}{ 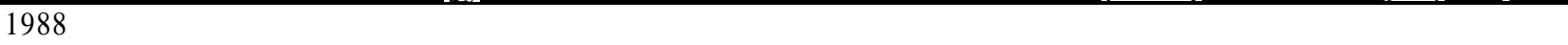 } \\
\hline April & 90.778 & 168.0 & 2.7 & 540 & 2.60 & 67 & 0.16 & $42 / 5.6$ & & & \\
\hline May & 81,900 & 116.0 & 3.9 & 706 & 2.90 & 72 & 0.19 & 45P.2 & 1.0 & 1.38 & 0.8 \\
\hline June & 76.150 & 76.3 & 6.0 & 998 & 3.30 & 83 & 0.23 & $51 / 10.6$ & 1.7 & 1.52 & 0.6 \\
\hline July & 47.100 & 60.5 & 7.5 & 778 & 3.50 & 90 & 0.17 & $54 / 12.2$ & 1.2 & 1.83 & 0.2 \\
\hline August & 41,600 & 44.4 & 10.2 & 938 & 3.80 & 98 & 0.19 & $55 / 12.8$ & 1.6 & 1.52 & 0.3 \\
\hline Sept. & 39.500 & 33.9 & 13.4 & 1167 & 4.04 & 103 & 0.22 & $55 / 12.8$ & 1.6 & 1.79 & 0.5 \\
\hline OCL & 37,500 & 26.8 & 16.9 & 1400 & 4.66 & 118 & 0.23 & $52 / 11.1$ & 1.3 & 1.90 & 0.4 \\
\hline Nov. & 37.450 & 23.3 & 19.5 & 1606 & 5.09 & 129 & 0.24 & 46P. 8 & 0.9 & 2.11 & 0.2 \\
\hline $\begin{array}{l}\text { Dec. } \\
1989\end{array}$ & 37,100 & 21.5 & 21.1 & 1724 & 5.23 & 133 & 0.25 & $40 / 4.4$ & 0.6 & 2.41 & 0.2 \\
\hline January & 37,000 & 19.6 & 23.2 & 1890 & 5.30 & 135 & 0.27 & 4014.4 & 0.5 & 1.61 & 0.2 \\
\hline Feb. & 36,800 & 19.9 & 22.8 & 1851 & 5.28 & 134 & 0.27 & 3913.9 & 0.3 & & 0.3 \\
\hline \multicolumn{12}{|c|}{ Averages for monitored ponds $11,12,13$, and 14} \\
\hline $\begin{array}{l}1988 \\
\text { April }\end{array}$ & 81,000 & & & & & & & & & & \\
\hline May & 80.100 & 112.8 & 4.0 & 710 & 2.90 & 73 & 0.19 & $45 n .2$ & - & & 1.2 \\
\hline June & 79,500 & 76.8 & 5.9 & 1036 & 3.30 & 83 & 0.24 & $51 / 10.6$ & - & & 0.7 \\
\hline July & 43.400 & 62.4 & 7.3 & 697 & 3.50 & 89 & 0.15 & $54 / 12.2$ & - & - & 0.2 \\
\hline August & 43,200 & 44.5 & 10.2 & 977 & 3.90 & 98 & 0.19 & 55112.8 & - & & 0.4 \\
\hline Sept. & 42,900 & 36.8 & 12.3 & 1176 & 3.90 & 100 & 0.23 & $55 / 12.8$ & - & & 1.0 \\
\hline $\mathrm{OCL}$ & 42.750 & 27.3 & 16.6 & 1565 & 4.63 & 118 & 0.26 & $52 / 11.1$ & - & & 0.3 \\
\hline Nov. & 42,700 & 23.9 & 19.0 & 1788 & 5.05 & 129 & 0.27 & $46 \mathrm{t} 7.8$ & - & & 0.1 \\
\hline $\begin{array}{l}\text { Dec. ** } \\
1989\end{array}$ & 40,300 & 22.4 & 20.3 & 1800 & 5.16 & 131 & 0.26 & $40 / 4.4$ & & & 0.1 \\
\hline January & 40,200 & 21.3 & 21.3 & 1887 & 5.15 & 131 & 0.28 & $40 / 4.4$ & - & & 0.2 \\
\hline Feb. & 38.800 & 20.6 & 22.0 & 1889 & 5.21 & 132 & 0.28 & 3913.9 & - & & 0.3 \\
\hline
\end{tabular}

* Density Index $=\quad$ Fish weight (lbs) $\overline{\text { Fish length (in) X Water vol.(ft }}{ }^{3}$ )

${ }^{* *} 9,360$ fish removed from pond 14 


\section{Release}

Fish were released on 30 and 31 March 1989. The size of fish in pond 13 was determined by hatchery personnel on 22 March and found to be $18.97 / \mathrm{b}$ ( $23.9 \mathrm{~g})$. A length distribution analysis on this date produced the following results:

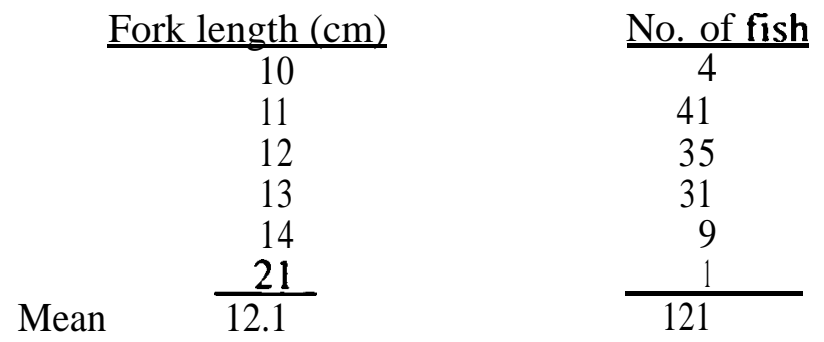

For the total number of fish released directly into the North Fork of the Clearwater River $(1,252,923)$, about $3.5 \%$ indicated some signs of BKD (popeye). Fish averaged $18.3 / \mathrm{b}$ $(24.8 \mathrm{~g})$ and were 5.43 inches $(138 \mathrm{~mm})$ in length.

\section{Water Chemistry}

The following is an example of measurements made on untreated North Fork river water:

$\begin{array}{lc}\text { Temperature }\left({ }^{\circ} \mathrm{F}\right) & 40.4 \\ \text { Dissolved oxygen }(\mathrm{mg} / \mathrm{L}) & 12.4 \\ \text { PH } & 7.5 \\ \text { Hardness }(\mathrm{mg} / \mathrm{L}) & 8 \\ \text { Chloride }(\mathrm{mg} / \mathrm{L}) & <3 \\ \text { Sodium }(\mathrm{mg} / \mathrm{L}) & 0 \\ \text { Potassium }(\mathrm{mg} / \mathrm{L}) & 0.5\end{array}$




\section{LEAVENWORTH NATIONAL FISH HATCHERY}

\section{Adult Spawners}

Adult spring chinook salmon spawners (Carson/Leavenworth stocks) arrived at the hatchery from 26 May to 30 June 1987. Adults were held in two ponds (50 x $150 \mathrm{ft}$ ) receiving water from wells and the Icicle River. Temperatures of the river water ranged from 8.9 to $18.3^{\circ} \mathrm{C}\left(48-65^{\circ} \mathrm{F}\right)$ and of the well from 8.9 to $10^{\circ} \mathrm{C}\left(48-50^{\circ} \mathrm{F}\right)$. At no time was the temperature allowed above $10^{\circ} \mathrm{C}\left(50^{\circ} \mathrm{F}\right)$ while adults were present. Flow rates varied according to the number of adults present (about $1 \mathrm{gpm} / \mathrm{fish}$ ) to a maximum of 2,342 gpm. From a total of 2,342 adults, $158(7 \%)$ died before spawning. While held, adults were treated with malachite green $(1 \mathrm{ppm})$ for 1 hour three times weekly from 24 June to 27 July. Each adult received two injections of erythromycin (0.4- $1.2 \mathrm{cc} / \mathrm{fish}$, depending on size). Spawning was conducted from 10 August to 2 September. There were six egg takes, numbered 1-6, taken on 10, 17, 19, 25, 26 August and 2 September, respectively. Takes 1-3 used a 1:1 ratio female to male. For takes 4-6 the ratio was 2:1. Fish monitored in this study (raceways $42,43,44$, and 45 ) were from egg take 4 . Spleen tissue from males and ovarian fluid from females were examined for IHN.

\section{Eggs}

Fertilized eggs from each female were placed in a separate colander and were then immersed in iodophore ( $75 \mathrm{mg} / \mathrm{L}$, buffered with sodium bicarbonate) for 30 minutes. Eggs were destroyed if either parent had gross BKD lesions. Well water was used for incubation, and average monthly temperatures were: September, $12^{\circ} \mathrm{C}\left(53^{\circ} \mathrm{F}\right)$; October, $8^{\circ} \mathrm{C}\left(46^{\circ} \mathrm{F}\right)$; November, $9^{\circ} \mathrm{C}\left(49^{\circ} \mathrm{F}\right)$; and December, $10^{\circ} \mathrm{C}\left(50^{\circ} \mathrm{F}\right)$. After incubation in individual colanders, the eyed eggs (93\%) were shocked and transferred to metal screen trays $(\sim 3,000 /$ tray $)$ which were placed in troughs until hatching. The transfer to trays 
occurred from mid-October to the first part of November. Eggs were treated three times each week with 167 ppm formalin until hatching.

\section{Early Rearing}

Fry were transferred from 1 December to mid-December, at $1.1 / 1 \mathrm{~b}$, to inside troughs (14 x $1.3 \times 0.86 \mathrm{ft} ; 15.6 \mathrm{cu} \mathrm{ft}$ rearing space; 9,00O/trough) and fiberglass tanks (14 x $3.1 \times 2.1 \mathrm{ft} ; 91.0 \mathrm{cu} \mathrm{ft}$ rearing space; 33,000/tank). Well water was used as the primary water source with trough and tank inflows 10 and $15 \mathrm{gpm}$, respectively. The average temperature for December and January was $8.80 \mathrm{C}(47.80 \mathrm{~F})$. In mid- to lateFebruary, fish (average size 425/lb) were moved to outside ponds. Fish in raceways 42-35 (monitored in this study) were transferred on 25 January and loaded at 96,000/raceway. Biodiet Starter \#2 was used for initial feeding (beginning 7-21 December). Fry from egg take \#4 were fed initially on 11 December. No antibiotics were fed during this period nor were there any treatments for diseases.

\section{Raceway Rearing}

Fish were transferred from inside uoughs and tanks to outside ponds during late January through late February. Fish monitored in this study were placed in flow-through raceways (76 x $8 \times 2.5 \mathrm{ft} ; 1,520 \mathrm{cu} \mathrm{ft}$ rearing space). In addition to raceways, both small $(3,876 \mathrm{cu} \mathrm{ft})$ and large $(13,572 \mathrm{cu} \mathrm{ft})$ Foster-Lucas ponds were used in rearing the fish to release. Fish used in this study were 2.2 in $(12 \mathrm{~mm})$ in length when uansferred to raceways (about 99,000/raceway; Density Index 0. IO). Icicle River and wells were used as water sources with inflows averaging $312 \mathrm{gpm}$. Average temperatures are shown in the table below. There was some freezing of ponds in January and February. 
Fish were fed Oregon Moist Pellets (1/32, 3/64, and 1/16) and Biodiet Moist (3 $\mathrm{mm})$. No antibiotics were fed. Fish in some of the Foster-Lucas ponds were treated for Ichthyophthirius multifillis with formalin (1 to 5,000), 1 hour/day on alternate days, for 2 weeks. However, treatment was unnecessary in the raceways. Fish were thinned in May 1988 to their final release numbers (see table below). Raceway 45 was used for monthly weight/length sampling during which water was lowered and fish crowded. Ponds were cleaned weekly in winter and 4 days/week in the summer by scrubbing the bottom surface with a brush while the water level was lowered.

In November 1988, 203,554 fish were coded-wire-tagged with the following codes: RW 42; 05-19-53; RW 43; 05-17-53; RW 44 \&45; 05-19-54. Raceways 46 and 47 were branded: RW 46: LA-7C-1, \& RD-76-1; RW 47: LA-7C-3

Other information on rearing densities, feeding, and growth is found in the following table:

\begin{tabular}{|c|c|c|c|c|c|c|c|c|c|c|c|}
\hline $\begin{array}{c}\text { Year } \\
\& \\
\text { Month } \\
\end{array}$ & $\begin{array}{l}\text { Fish/ } \\
\text { pond }\end{array}$ & Fish/lb & $\begin{array}{l}\text { Wh } \\
(\mathrm{g})\end{array}$ & $\begin{array}{l}\text { Lbs } \\
\text { fish/ } \\
\text { pond }\end{array}$ & $\begin{array}{c}\mathrm{Fl} \\
\text { (in) }\end{array}$ & $\begin{array}{c}\mathrm{Fl} \\
(\mathrm{mm})\end{array}$ & $\begin{array}{l}\text { Density } \\
\text { Index }\end{array}$ & $\begin{array}{l}\text { Water } \\
\text { temp. } \\
\left({ }^{\circ} \mathrm{F} /{ }^{p} \mathrm{C}\right)\end{array}$ & $\begin{array}{c}\text { Food } \\
\text { rate } \\
(\% w v \\
\text { (hv) }\end{array}$ & $\begin{array}{c}\text { Food } \\
\text { cower. } \\
\text { (food/ } \\
8 \text { gain) }\end{array}$ & $\begin{array}{l}\text { hlort. } \\
\left(C_{C}^{*}\right)\end{array}$ \\
\hline 1987 & & & & & & & & & & & \\
\hline $\begin{array}{l}\text { Dec. } \\
1988\end{array}$ & 9.000 & 674 & 0.67 & 13.4 & 1.79 & 55 & 0.48 & $48 / 8.8$ & 1.0 & 0.62 & 0.40 \\
\hline January & 9,000 & 396 & 1.15 & 22.8 & 2.15 & 63 & 1.46 & $48 / 8.8$ & 1.0 & 1.07 & 0.30 \\
\hline Feb. & 96,000 & 241 & 1.88 & 398 & 2.49 & 77 & 0.06 & $44 / 6.5$ & 1.0 & 0.73 & 0.07 \\
\hline March & 95.950 & 122 & 3.72 & 786 & 3.02 & 84 & 0.09 & $45 \pi .2$ & 1.0 & 0.88 & 0.03 \\
\hline April & 95,900 & 95 & 4.78 & 1,009 & 3.32 & 84 & 0.19 & $44 / 6.7$ & 1.0 & 1.05 & 0.01 \\
\hline May & 26,394 & 76 & 5.97 & 347 & 3.54 & 90 & 0.06 & $44 / 6.7$ & 1.0 & 1.34 & 0 \\
\hline June & 26,391 & 58 & 7.83 & 455 & 3.89 & 99 & 0.08 & $48 / 9.0$ & 1.0 & 1.44 & 0.01 \\
\hline July & 26,383 & 43 & 10.56 & 614 & 4.30 & 109 & 0.09 & 55112.6 & 1.0 & 1.52 & 0.01 \\
\hline August & 26,371 & 33 & 13.76 & 799 & 4.17 & 106 & 0.13 & 5019.9 & 1.0 & 1.52 & 0.01 \\
\hline Scpt. & 26,354 & 27 & 16.81 & 976 & 4.08 & 104 & 0.18 & $46 / 7.9$ & 1.0 & 1.82 & 0.06 \\
\hline Oct. & 26,336 & 24 & 18.92 & 1,097 & 4.54 & 115 & 0.19 & $44 / 6.8$ & 1.0 & 2.43 & 0.01 \\
\hline Nov. & 25,136 & 25 & 18.16 & 1,005 & 4.79 & 122 & 0.17 & $36 / 2.1$ & 0.4 & -2.87 & $0.0^{\prime}$ \\
\hline $\begin{array}{l}\text { Dec. } \\
1989\end{array}$ & 25,127 & 26 & 17.46 & 966 & 4.65 & 118 & 0.18 & $32 / 0.2$ & 0.1 & -0.51 & 0.04 \\
\hline January & 25,122 & 25 & 18.16 & 1,005 & 4.65 & 118 & 0.18 & $34 / 0.9$ & 0.2 & 18.73 & $0.0^{\prime}$ \\
\hline Feb. & 25,122 & 25 & 18.16 & 1,005 & 4.72 & 120 & 0.18 & $34 / 1.1$ & 0.2 & 0 & 0 \\
\hline March & 24,996 & 22 & 20.64 & 1.136 & 4.94 & 126 & 0.19 & $35 / 1.8$ & 0.4 & 0.95 & 0.50 \\
\hline Apnl & & & - & - & & 132 & & $39 / 3.9$ & -- & 1.12 & - \\
\hline
\end{tabular}

* Density Index $=$

$\overline{\left.\text { Fish length (in) X Water vol.(ft }{ }^{3}\right)}$ 
Release

Fish were released on 19 April at $20 / \mathbf{b}$ by opening the drain to the ponds which fed directly into Icicle River.

\title{
WARM SPRINGS NATIONAL FISH HATCHERY
}

\author{
Adult Spawners
}

Adult spring chinook salmon (Warm Springs/Deschutes stock) arrived at the hatchery between 29 April and 30 September 1987. The mid-portion of the run arrived in mid-May. Adults were held in two oval concrete ponds with sloping sides. Total volume of both ponds was $8,350 \mathrm{cu} f$. Incoming water (about $400 \mathrm{gpm}$ ) was taken from the Warm Springs River, passed through a sand filter, subjected to ultraviolet radiation, and chilled when needed to keep the temperature at 9-10 $\mathrm{C}\left(48-50^{\circ} \mathrm{F}\right)$. Water was recirculated with about $50 \%$ fresh water added. All hatchery adults had been, as juveniles, either tagged with a coded-wire tag (adipose fin clip) or marked with another fin clip. As adults entered the holding ponds, both hatchery and wild fish were anesthetized with a mixture of quinaldine and MS-222, injected with erythromycin, and given a dip in a malachite green bath (I ppm). Wild fish (those with no marks) were then released to proceed upriver. All adults held at the hatchery received a second injection of erythromycin. In August, there was an outbreak of Ichthvonhthirius multifillis; fish were treated twice weekly with 167 ppm formalin until spawned. There were 235 prespawning mortalities, primarily due to $\underline{\mathbf{I}}$. multifiliis. Adults also received a malachite green bath three times each week. Samples of kidney and spleen were taken from males, and ovarian fluid from females, and examined for IHN. One male and 10 females were IH.N positive. Eggs from these fish were kept separate from the others and the progeny were reared in a separate raceway. A total of 267 females and 197 males were spawmed between 21 August and 23 Scptcmbcr. In nearly all 
instances, eggs from each female were fertilized with sperm from only one male. Eggs from eight females showing gross BKD signs were destroyed. Three males also were grossly BKD infected. Eggs were taken on 21 and 27 August, and on 2,8, 14, 18, and 23 September 1987; a total of 724,613 eggs were obtained.

\section{Eggs}

Fertilized eggs from each female were placed in individual incubation buckets, water hardened in iodophore (Argentyne, $75 \mathrm{ppm}, 30$ minutes) and incubated in troughs using treated river water. Water was chilled so the temperature would not exceed $12^{\circ} \mathrm{C}$ $\left(52^{\circ} \mathrm{F}\right)$ until normal river temperatures dropped below that value (about 1 October).

Temperatures then remained as ambient until initial feeding. At eye-up, eggs $(691,750)$ were shocked in salt water, picked, and moved to Heath trays. There was a 4.5\% loss to the eyed stage. Eggs received no other chemical treatment during incubation. Hatching occurred in mid-November.

Early Rearing

In late December, fry were transferred from Heath trays to inside fiberglass tanks, with 40,000 to 50,000 fish per tank ( $3 \times 13 \times 2$-ft deep; water volume $=78 \mathrm{cu} \mathrm{ft}$ ). Treated river water was used with an inflow of $15 \mathrm{gpm}$ and temperatures 8-10 $\mathrm{C}\left(46-50^{\circ} \mathrm{F}\right)$. First feeding was 25 December with Biomoist Starter II, later Biomoist Starter III. No antibiotics were fed during early rearing and there were no other treatments. Fish were fed initially every $1 / 2$ hour, later every hour just before ponding. 
Raceway Rearing

Fish were transferred to outside raceways beginning 16 March 1988. Raceways were modified Burrow's ponds with the center divider closed at the inlet end but open at the outlet end. The ponds were $16 \times 75 \times 1.54-\mathrm{ft}$ deep $(3,712 \mathrm{cu} \mathrm{ft})$, with the center divider open at the tail end of the raceway, allowing fish free access to both sides. Approximately 52,000 fish were placed in each raceway. Untreated river water was the source with inflows at $500 \mathrm{gpm}$ in winter and $700 \mathrm{gpm}$ in summer. Fish were fed Biomoist diet (by hand, four to five times daily) in graded sizes up to $3 \mathrm{~mm}$ prior to release. Ponds were cleaned weekly in the summer and one or two times each month in winter. During the first part of July 1988, it was recommended that the fish be treated for 4 days with formalin (200 ppm) because of a high incidence of $\underline{I}$. multifillis. In November 1988, the incidence of Nanophyetus was observed to be high (60-70 metacercarial cysts in the posterior kidney).

Fish were coded-wire-tagged or fin clipped between 7 April and 4 May 1988 (90180/b) and apportioned to about 52,000/raceway. In late September 1988, fish were graded, and those $140 \mathrm{~mm}$ and longer were released. The remaining, smaller fish (those used in this study) were kept in raceways with the following numbers (count at release 5 April 1989):

\begin{tabular}{|c|c|c|}
\hline$\underline{\text { Racewav number }}$ & $\underline{\text { Number of fish }}$ & $\underline{\text { Wire tag } \&}$ \\
\hline 11 & 30,253 & $05-20-05$ \\
\hline 12 & 34,996 & $05-20-07$ \\
\hline 13 & $62,788^{*}$ & $05-20-06 \& 05-20-08$ \\
\hline
\end{tabular}

These fish were then fed oxytetracycline to provide a mark to distinguish them from the larger fish that were released carrying the same wire-tag code. 
Information on rearing densities, growth, temperatures, and food conversions are found in the following table:

\begin{tabular}{|c|c|c|c|c|c|c|c|c|}
\hline $\begin{array}{c}\text { Year } \\
\& \\
\text { Month }\end{array}$ & $\begin{array}{l}\text { Fish/ } \\
\text { pond }\end{array}$ & Fish/lb & $\begin{array}{l}W t \\
(g)\end{array}$ & $\begin{array}{l}\text { Lbs } \\
\text { fish/ } \\
\text { pond }\end{array}$ & $\begin{array}{l}\mathrm{FI} \\
\text { (in) }\end{array}$ & $\begin{array}{l}\text { Water } \\
\text { tcmp. } \\
\text { (oF/o } \mathbf{C})\end{array}$ & $\begin{array}{c}\text { Food } \\
\text { cower. } \\
\text { (food/ } \\
\% \text { g a i n }\end{array}$ & $\begin{array}{r}\text { Mort. } \\
\quad \quad(c i c)\end{array}$ \\
\hline 1987 & & & & & & & & \\
\hline De-c. & 691,750 & 532 & 0.9 & - & $\begin{array}{r}1.37 \\
\text { (Est) }\end{array}$ & - & & \\
\hline 1988 & & & & & & & & \\
\hline $\begin{array}{l}\text { January } \\
\text { Feb. }\end{array}$ & - & & - & - & - & - & & \\
\hline March & 691,750 & 190 & 2.4 & - & - & 4115.0 & & \\
\hline April & 691,750 & 105 & 4.3 & - & - & $47 / 8.3$ & 0.9 & 0.1 \\
\hline May & 626,857 & 53.0 & 8.6 & - & - & 51110.6 & 1.1 & 0.1 \\
\hline June & 626,352 & 29.0 & 15.7 & - & - & 57113.9 & 1.1 & 0.4 \\
\hline July & 623,835 & 21.1 & 21.6 & - & - & 61116.1 & 1.6 & 0.1 \\
\hline August & 623.038 & 18.4 & 25.2 & - & - & 59115.0 & 2.4 & 0.1 \\
\hline Sept. * & $\begin{array}{ll}4 & 16,887\end{array}$ & 18.6 & 25.2 & 3,736 & - & $53 / 11.7$ & 1.5 & 0.5 \\
\hline Oct. & 414,809 & 15.9 & 28.4 & 4,348 & - & $48 / 8.9$ & 1.5 & 0.5 \\
\hline Nov. & 412,826 & 15.1 & 30.3 & 4,557 & - & 3913.9 & 1.5 & 0.2 \\
\hline $\begin{array}{l}\text { Dec. } \\
1989\end{array}$ & 411.919 & 14.7 & 30.3 & 4.670 & - & 3511.7 & 2.0 & 0.2 \\
\hline January & 411,287 & 14.4 & 32.4 & 4,760 & - & 3511.7 & 3.1 & 0.5 \\
\hline Feb. & 409.965 & 13.8 & 32.4 & 4.940 & - & $33 / 0$ & 1.5 & 1.1 \\
\hline March & 404,965 & 13.1 & 34.9 & 5.152 & - & 3813.3 & 1.5 & 0.2 \\
\hline April & 404.093 & 12.0 & 37.8 & 5.612 & - & $45 / 7.2$ & & \\
\hline
\end{tabular}

** 205,315 fish released on 30 September.

Release

The larger fish were released on 30 September 1988 and were 1 1/lb. The small fish were released 5 April 1989 at 15/lb, through a system of pipes that led directly to the river. 


\title{
WILLAMETTE HATCHERY
}

\author{
Adult Spawners
}

Adult spring chinook salmon spawners (Willamette stock) arrived at the Dexter, Oregon holding ponds from the first week of June to the first week of September 1987. Adults were trucked to the hatchery from Dexter (approximately 30 miles) and held in a dirt holding pond of irregular shape (approximately 250 x 20 x 2-ft deep; 10,000 cu ft). Inflowing water $(2,500-2,800 \mathrm{cfs})$ was from Salmon Creek and averaged from 12 to $14^{\circ} \mathrm{C}$ ( 54 to $57^{\circ} \mathrm{F}$ ) during the holding period. From a total of 1,758 adults ( 679 males, 1,079 females), 509 (29\%) suffered prespawning mortality (186 males, 323 females). Adults were injected with oxytetracycline at the time of collection at Dexter $(0.5 \mathrm{ml} / 16 \mathrm{lbs})$.

Spawning began the first week of September (1987) and eggs were taken on the dates shown below:

$\begin{array}{lllllllll}\text { Date of egg take: } \quad 9 / 7 & 9 / 15 & 9 / 18 & 9 / 22 & 9 / 25 & 9 / 28 & 10 / 1 & 10 / 5 & \text { Total }\end{array}$

$\begin{array}{llllllllll}\text { Females spawned: } & 143 & 201 & 95 & 165 & 50 & 40 & 19 & 9 & 722\end{array}$
A total of $3,594,000$ eggs were taken. Sperm from several males was pooled and used to fertilize the eggs.

No IHN was detected; however, low levels of BKD were observed in spawned adults. Some furunculosis. enteric red mouth, Ceratomvxa shasta, and low levels of BKD were found in the prespawning mortalities.

\section{Eggs}

Green eggs from early takes $(9 / 7-9 / 18)$ were placed in baskets $(25,000-26,000$ eggs/basket), water hardened in Salmon Creek water, and placed in redwood troughs with inflowing water at about 12 gpm. Eggs from later takes (9/25-10/5) were placed in Heath 
uays with 9,000-10,000 eggs/unit and inflowing water at 5 gpm. Egg loss was 12.6\%. Fish monitored in this study (April and May release groups) were from the later egg takes. Once the eggs were in their containers they were given a medicated bath for 10 minutes using a solution of Argentyne. Eggs were incubated in ambient water from Salmon Creek (average temperatures 3-140 C $\left(37-5^{\circ} \mathbf{F}\right)$ during September 1987 to February 1988. At eye-up, eggs were shocked and picked. Hatching occurred from late December to late February.

\section{Early Rearing}

As eggs hatched, the fish were transferred to inside fiberglass tanks (Canadian) that measured $16 \mathrm{ft}$ x 32 in x 21 -in deep (54,000-88,000 fish/tank at 1,221 - 1,308 fish/lb, unfed fry). Each tank received Salmon Creek water at 10-20 gpm, 3-70 C (38-45 $\mathrm{F})$. First feeding occurred about 10 days after transfer to tanks. The delay in feeding was to help control internal fungus. After about 3 weeks in the fiberglass tanks, fish were transferred to outside raceways. Biodiet Starter \#2 was used for initial feeding. Fry loss was $58,000(1.8 \%)$. There were no treatments for disease during the early rearing period.

\section{Raceway Rearing}

Outside rearing ponds consisted of modified Burrow's ponds measuring $80 \mathrm{x} 20 \mathrm{x}$ 2.6-ft water depth (approximately 3,690 cu ft). No more than 350,000 fish were placed in a pond, with a maximum of 4,000 lbs/pond. Inflowing water came from Salmon Creek and ranged from 100 to $150 \mathrm{gpm}$ initially, then up to $450 \mathrm{gpm}$ as fish grew. Beginning in April 1988, fish were fed OMP pellets which ranged in size from $3 / 64$ to $1 / 8$ in as fish grew. Fish used in this study, which were released in April and May 1989, received 
Biomoist (4 mm) from March until release. Fish were fed on demand until May 1988, then according to targeted sizes until release:

$\begin{array}{lccccccccccc}\text { Month } & \text { May } & \text { June } & \text { July } & \text { Aug } & \text { Sept } & \text { Oct } & \text { Nov } & \text { Doc } & \text { Jan } & \text { Fcb } & \text { Mar } \\ \text { Target (fish/b) } & 196 & 95-97 & 45 & 25 & 15 & 12 & 10.5 & 9.8 & 9.5 & 9.0 & 9.0\end{array}$

In September 1988, fish were tagged with coded-wire tags and divided into groups for later releases. Those monitored in this study were tagged on 1 and 2 September and were placed in a divided raceway with slightly over 22,000 fish in each half of the pond (ponds 21A, code 07-50-32; and pond $21 \mathrm{~B}$, code 07-50-35). As part of the normal production plan, fish from earlier egg takes ( 7 and 15 September) were transferred to Dexter during April 1987 and released in November 1988.

\section{Release}

Some of the juveniles (one third of the production) of this brood year were released from Dexter on 14-15 November 1988. Most of the remaining two thirds of the production was released on 6 March 1989, with subsequent releases of groups monitored in this study on 15 April (11.2/lb) and 4 May (10.0/b). Fish were released at Pengra Boat Launch, below Dexter Dam in the Middle Fork of the Willamette River after trucking from the hatchery (about 30 miles). 
Information on rearing densities, growth, temperatures, and food conversion are found in the following table:

\begin{tabular}{|c|c|c|c|c|c|c|c|}
\hline $\begin{array}{c}\text { Ycar } \\
\& \\
\text { Month } \\
\end{array}$ & $\begin{array}{l}\text { Fish/ } \\
\text { pond }\end{array}$ & Fish/lb & $\begin{array}{l}W \mathrm{~W} \\
(\mathrm{~g})\end{array}$ & $\begin{array}{l}\text { Lbs } \\
\text { fish/ } \\
\text { pond }\end{array}$ & $\begin{array}{l}\text { Water } \\
\text { temp. } \\
\left({ }^{\circ} \mathrm{F} /{ }^{\circ} \mathrm{C}\right)\end{array}$ & $\begin{array}{c}\text { Food } \\
\text { conver. } \\
\text { (food/ } \\
\sigma_{c} \text { gain) }\end{array}$ & $\begin{array}{c}\text { Mon. } \\
(C, C)\end{array}$ \\
\hline 1987 & & & & & & & \\
\hline $\begin{array}{l}\text { Dec. } \\
1988\end{array}$ & - & & & & $40.2 / 4.6$ & & \\
\hline January & - & & & & $39.7 / 4.3$ & & \\
\hline Feb. & - & & & & $40.8 / 4.9$ & & \\
\hline March & 262.066 & 426 & 1.1 & 615 & $42.5 / 5.8$ & 0.93 & - \\
\hline April & 199.349 & 198 & 2.3 & 1,005 & $45.5 f 7.5$ & 0.68 & - \\
\hline May & 112,743 & 170 & 2.6 & 622 & $47.6 / 8.7$ & 3.11 & - \\
\hline June & 108.917 & 89 & 5.1 & 1,223 & $52.3 / 11.3$ & 0.49 & - \\
\hline July & 43,635 & 48 & 9.5 & 909 & $57.7 / 14.3$ & 1.43 & - \\
\hline August & 43.134 & 25 & 18.4 & 1,754 & $57.5 / 14.3$ & 1.20 & - \\
\hline Sept. A & 22.631 & 21 & 21.6 & 1,078 & $52.5 / 11.4$ & 1.15 & $<0.01$ \\
\hline Scp. B & 22,892 & 21 & 21.6 & 1,090 & & & co. 01 \\
\hline OCL A & 22,628 & 18.6 & 24.4 & 1,782 & $50.0 / 10.0$ & 1.43 & $<0.01$ \\
\hline Oct. B & 22.891 & 19.1 & 23.86 & 1,802 & & _- & co. 01 \\
\hline Nov. A & 22,626 & 16.8 & 27.0 & 1.337 & $44.0 / 6.7$ & & 0.04 \\
\hline Nov. B & 22.890 & 11.8 & 38.5 & 1,940 & & & 0.02 \\
\hline Dec. A & 22,617 & 15.0 & 30.3 & 1,508 & $39.9 / 4.3$ & 1.32 & 0.02 \\
\hline $\begin{array}{l}\text { Dec. B } \\
1989\end{array}$ & 22,886 & 16.0 & 28.4 & 1,430 & & & 0.04 \\
\hline Jan. A & 22.612 & 14.2 & 32.0 & 1.592 & $39.7 / 4.3$ & 2.38 & $<0.01$ \\
\hline Jan. B & 22,878 & 14.7 & 30.9 & 1,556 & & & $<0.01$ \\
\hline Feb. A & 22.610 & 14.0 & 32.4 & 1.615 & $37.8 / 3.2$ & 3.05 & 0.07 \\
\hline Feb. B & 22,877 & 13.0 & 34.9 & 1,760 & & & 0.02 \\
\hline Mar. A & 22,545 & 11.4 & 39.8 & 1,978 & $41.7 / 5.4$ & 2.50 & \\
\hline Mar. B & 22,873 & 12.6 & 36.0 & 1,815 & & & \\
\hline April B & 22,849 & 10.0 & 45.4 & 2,284 & $45.0 \mathrm{f} 7.2$ & 2.40 & - \\
\hline
\end{tabular}

$\mathrm{A}=$ pond $21 \mathrm{~A}$, April release; $\mathrm{B}=$ pond $21 \mathrm{~B}$, May release.

Pond volume $=3,690 \mathrm{cu} \mathrm{ft}$ for production fish; pond volume $=1,835 \mathrm{cu} \mathrm{ft}$ in $21 \mathrm{~A}$ and $21 \mathrm{~B}$. 


\section{COMMENTS}

Tables 1 and 2 compare average monthly weights (fish/lb and grams) of brood year 1987 production spring chinook salmon at the four monitored hatcheries during most of the rearing time. Figure 1 compares growth curves, showing some important differences in rates of growth, some of which are due to varying temperature patterns (Fig. 2, Tables 3 and 4). It is interesting that spring chinook salmon at Willammette Hatchery begin as the smallest fish in the four hatcheries. Nevertheless, they overtook in size fish at Leavenworth and Dworshak by June and July 1988, and Warm Springs by January 1989 . It must be remembered, however, that Warm Springs released their larger fish the previous September. 
Table 1.-- Number of fish/lb during the rearing period at the four hatcheries monitored in the smolt quality assessment.

\begin{tabular}{ccccc}
\hline & \multicolumn{4}{c}{ Number of fish/lb } \\
\cline { 2 - 5 } Date & Dworshak & Leavenworth & Willamette & Warm Springs \\
\hline $\mathbf{1 9 8 7}$ Dec & -- & 674 & -- & 532 \\
Feb & -- & 396 & -- & -- \\
Mar & -- & 241 & -- & -- \\
Apr & -- & 122 & 426 & 190 \\
May & 168 & 95 & 198 & 105 \\
Jun & 116 & 76 & 170 & 53 \\
Jul & 76.3 & 58 & 89 & 29 \\
Aug & 60.5 & 43 & 48 & 21 \\
Sep & 44.4 & 33 & 25 & 18 \\
Oct & 33.9 & 27 & 21 & $18 \%$ \\
Nov & 26.8 & 24 & 19 & 16 \\
Dec & 23.3 & 25 & 17 & 15 \\
Jan & 21.5 & 26 & 16 & 15 \\
Feb & 19.6 & 25 & 14 & 14 \\
Mar & 19.9 & 25 & 13 & 14 \\
Apr & 19.0 & 22 & 12 & 13 \\
& -- & 20 & 10 & \\
\hline 989 & & & & \\
\hline
\end{tabular}

a Fish were graded and larger ones were released on 30 September. 
Table 2. -- Weight (g) of fish during the rearing period at the four hatcheries monitored in the smolt quality assessment.

\begin{tabular}{ccccc}
\hline & \multicolumn{5}{c}{ Weight of fish (g) } \\
\cline { 2 - 5 } Date & Dworshak & Leavenworth & Willamette & Warm Springs \\
\hline$\underline{\text { J1988a }}$ Dec & -- & 0.67 & -- & 0.9 \\
Feb & -- & 1.15 & -- & \\
Mar & -- & 1.88 & -- & \\
Apr & -- & 3.72 & 1.1 & 2.4 \\
May & 2.7 & 4.78 & 2.3 & 4.3 \\
Jun & 3.9 & 5.97 & 2.7 & 8.6 \\
Jul & 6.0 & 7.83 & 5.1 & 15.7 \\
Aug & 7.5 & 10.56 & 9.5 & 21.6 \\
Sep & 10.2 & 13.76 & 18.4 & 25.2 \\
Oct & 13.4 & 16.81 & 21.6 & $25.2 \mathbf{a}$ \\
Nov & 16.9 & 18.92 & 23.9 & 28.4 \\
Dec & 19.5 & 18.16 & 26.7 & 30.3 \\
Jan & 21.1 & 17.46 & 28.4 & 30.3 \\
Feb & 23.2 & 18.16 & 32.4 & 32.4 \\
Mar & 22.8 & 18.16 & 34.9 & 32.4 \\
Apr & 23.9 & 20.64 & 37.8 & 34.9 \\
& -- & 22.7 & 45.4 & 37.8 \\
\hline 989 & & & & \\
\hline
\end{tabular}

aFish were graded and larger ones were released on 30 September. 
Figure 1. -- Growth curves for spring chinook salmon reared at Dworshak, Leavenworth. Warm Springs, and Willamette Hatcheries.

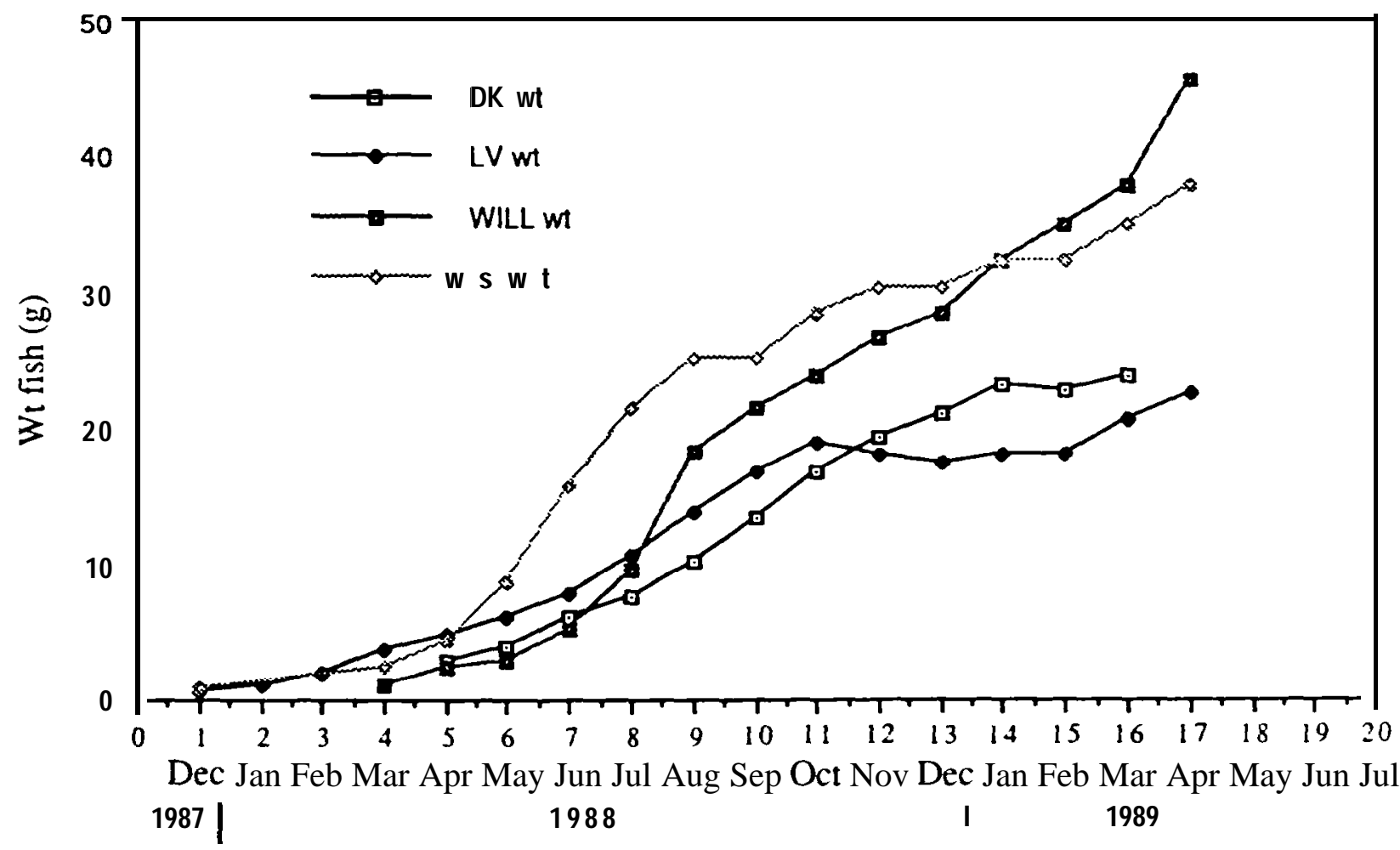


Figure 2. -- Temperature curves for rearing waters of brood year 1987 spring chinook salmon at Dworshsk, Leavenworth, Warm Springs, and Willamette Hatcheries.

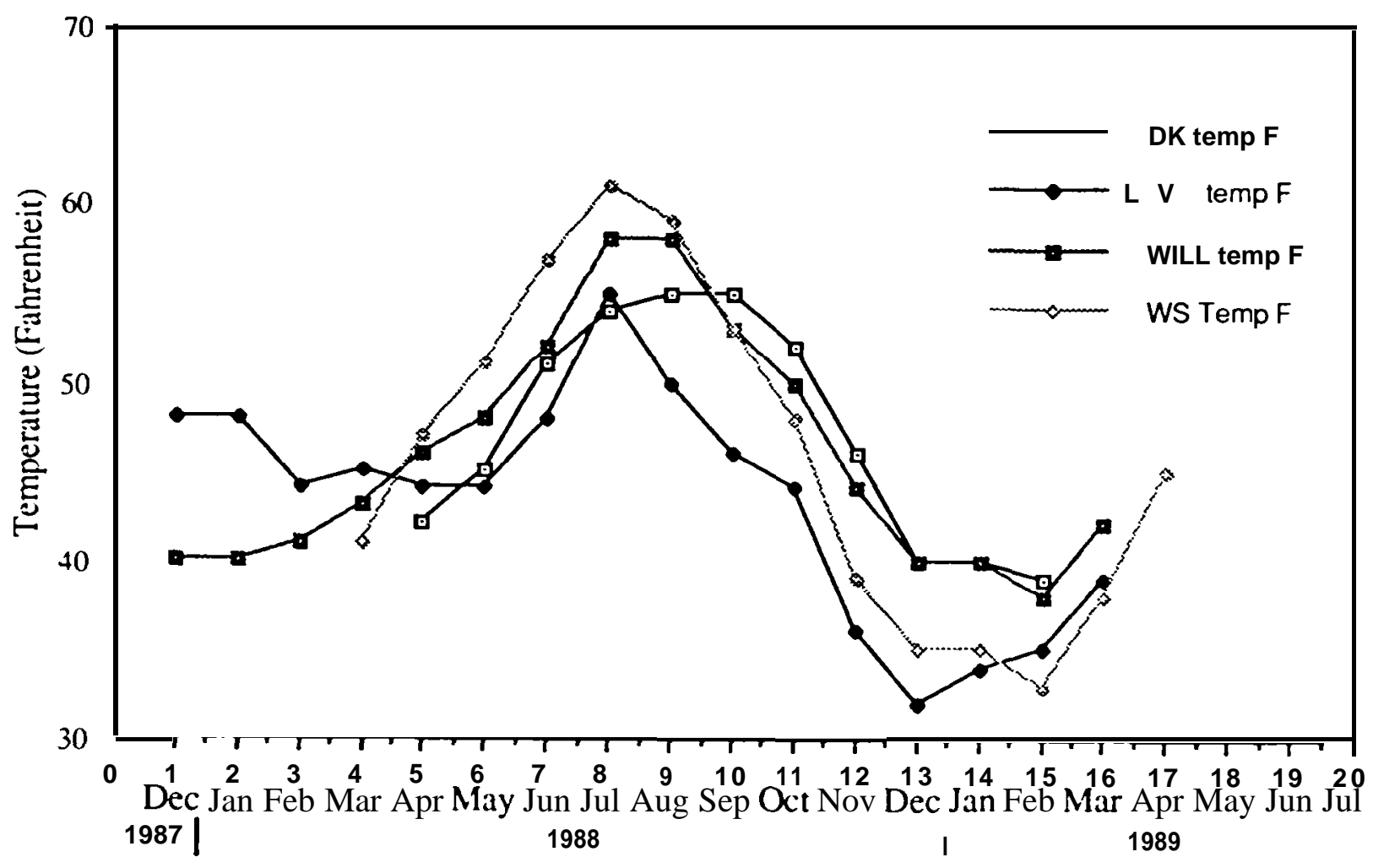


Table 3. -- Temperature $\left({ }^{\circ}\right.$ F) during the rearing period at the four hatcheries monitored in the smolt quality assessment.

\begin{tabular}{|c|c|c|c|c|c|}
\hline \multicolumn{2}{|c|}{ Date } & \multirow{2}{*}{$\begin{array}{c}\text { Dworshak } \\
--\end{array}$} & \multirow{2}{*}{$\begin{array}{c}\text { Leavenworth } \\
48\end{array}$} & \multirow{2}{*}{$\begin{array}{c}\text { Willanxette } \\
40\end{array}$} & \multirow[t]{2}{*}{ Warm Springs } \\
\hline 1987 & Doc & & & & \\
\hline \multirow[t]{12}{*}{$\underline{1988}$} & Jan & -- & 48 & 40 & \\
\hline & Feb & -- & 44 & 41 & -- \\
\hline & Mar & -- & 45 & 43 & 41 \\
\hline & Apr & 42 & 44 & 46 & 47 \\
\hline & May & 45 & 44 & 38 & 51 \\
\hline & Jun & 51 & 48 & 52 & 57 \\
\hline & Jul & 54 & 55 & 58 & 61 \\
\hline & Aug & 55 & 50 & 58 & 59 \\
\hline & Sep & 55 & 46 & 53 & 53 \\
\hline & $a_{t}$ & 52 & 44 & 50 & 48 \\
\hline & Nov & 46 & 36 & 41 & 39 \\
\hline & $D x$ & 40 & 32 & 40 & 35 \\
\hline \multirow[t]{4}{*}{$\underline{\mathrm{J1989a}}$} & $\mathrm{n}$ & 40 & 33 & 40 & 35 \\
\hline & $\mathrm{Feb}$ & 39 & 35 & 38 & 33 \\
\hline & Mar & -- & 39 & 42 & 38 \\
\hline & Apr & -- & & & 45 \\
\hline
\end{tabular}


Table 4. -- Temperature $\left({ }^{\circ} \mathrm{C}\right)$ during the rearing period at the four hatcheries monitored in the smolt quality assessment.

\begin{tabular}{ccccc}
\hline Date & Dworshak & Leavenworth & Willamette & Warm Springs \\
\hline 1987 Dec & & 8.8 & 4.4 & \\
1988 J a n & & 8.8 & 4.4 & \\
Feb & -- & 6.5 & 5.0 & -- \\
Mar & -- & 7.2 & 6.1 & 5.0 \\
Apr & 5.6 & 6.7 & 7.9 & 8.3 \\
May & 7.2 & 6.7 & 9.0 & 10.6 \\
Jun & 10.6 & 9.0 & 11.1 & 13.9 \\
Jul & 12.2 & 12.6 & $1-\mathrm{I} .4$ & 16.1 \\
Aug & 12.8 & 9.9 & 14.4 & 15.0 \\
Sep & 12.8 & 7.9 & 11.7 & 11.7 \\
Oct & 11.1 & 6.8 & 10.0 & 8.9 \\
Nov & 7.8 & 2.1 & 6.7 & 3.3 \\
Dec & 4.4 & 0.2 & 4.4 & 1.7 \\
1989 Jan & 4.4 & 1.1 & 4.4 & 1.7 \\
Feb & 3.9 & 1.8 & 3.3 & 0 \\
Mar & -- & 3.9 & 5.6 & 7.2 \\
Apr & & & -- & \\
\hline
\end{tabular}

